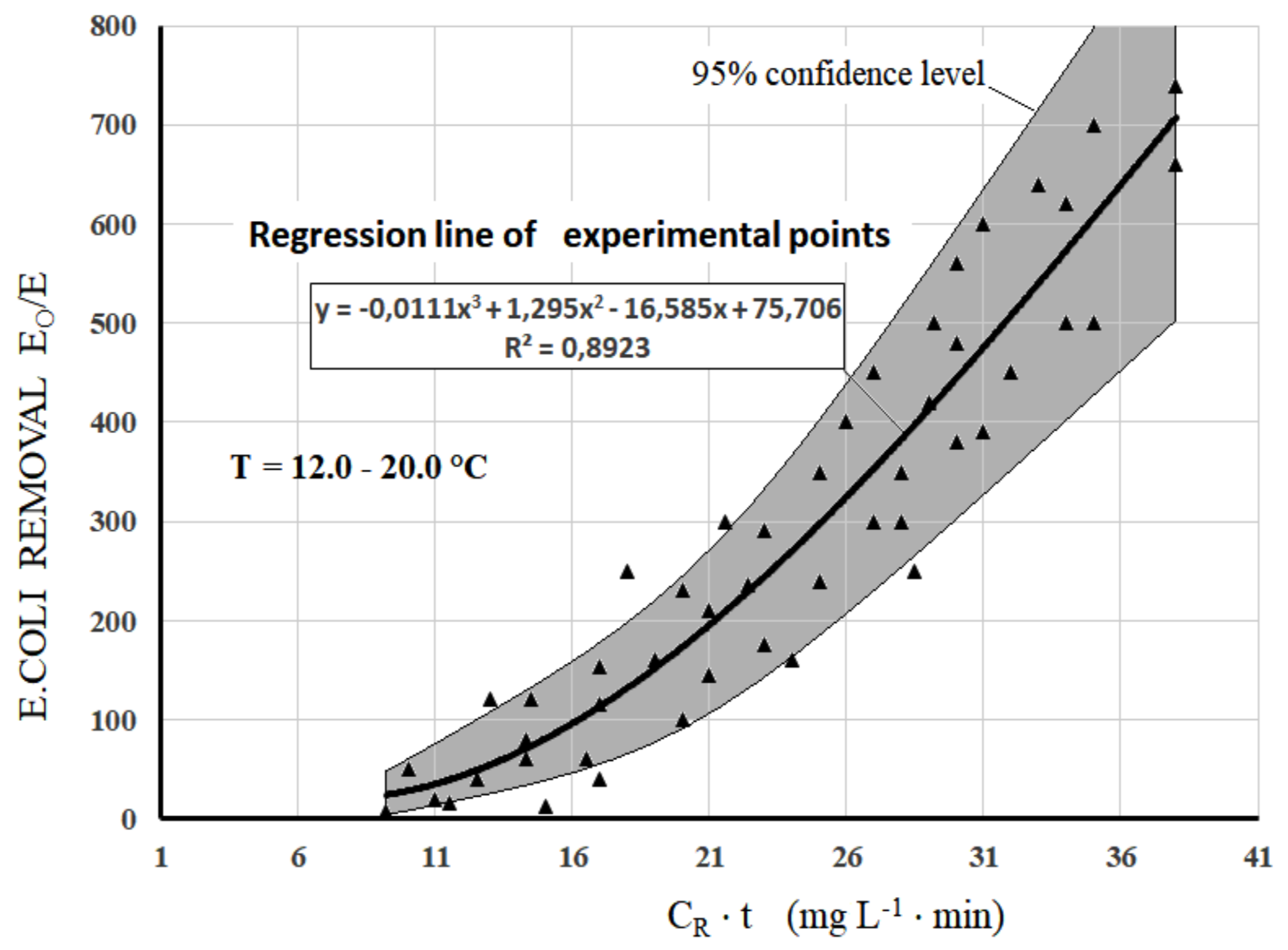

ISSN $=$ 1980-993X (Online) 


\section{EDITORIAL BOARD}

\section{Editors}

Getulio Teixeira Batista (Emeritus Editor) Universidade de Taubaté - UNITAU, BR

Nelson Wellausen Dias (Editor-in-Chief), Fundação Instituto Brasileiro de Geografia e Estatística - IBGE, BR

Ana Aparecida da Silva Almeida

Marcelo dos Santos Targa

Andrea Giuseppe Capodaglio

Arianna Callegari

Antonio Teixeira de Matos

Apostol Tiberiu

Claudia M. dos S. Cordovil

Dar Roberts

Giordano Urbini

Gustaf Olsson

Hélio Nobile Diniz

Ignacio Morell Evangelista

János Fehér

Julio Cesar Pascale Palhares

Luis Antonio Merino

Maria Cristina Collivignarelli

Massimo Raboni

Petr Hlavínek

Richarde Marques da Silva

Stefan Stanko

Teresa Maria Reyna

Yosio Edemir Shimabukuro

Zhongliang Liu Beijing

Text Editor

Reference Editor

Peer-Reviewing Process

System Analyst

Secretary and Communication

\section{Associate Editors}

Universidade de Taubaté (UNITAU), BR

Universidade de Taubaté (UNITAU), BR

\section{Editorial Commission}

University of Pavia, ITALY

Università degli Studi di Pavia, ITALY

Universidade Federal de Minas Gerais (UFMG), BR

University Politechnica of Bucharest, Romênia

Centro de estudos de Engenharia Rural (CEER), Lisboa, Portugal

University of California, Santa Barbara, United States

University of Insubria, Varese, Italy

Lund University, Lund, Sweden

Inst. Geológico, Sec. do Meio Amb. do Est. de SP (IG/SMA), BR

University Jaume I- Pesticides and Water Research Institute, Spain

Debrecen University, Hungary

Embrapa Pecuária Sudeste, CPPSE, São Carlos, SP, BR

Institute of Regional Medicine, National University of the Northeast, Corrientes, Argentina

University of Pavia, Depart. of Civil Engineering and Architecture, Italy

LIUC - University "Cattaneo", School of Industrial Engineering, Italy

Brno University of Technology República Tcheca

Universidade Federal da Paraíba (UFPB), BR

Slovak Technical University in Bratislava Slovak, Eslováquia

Universidad Nacional de Córdoba, Argentina

Instituto Nacional de Pesquisas Espaciais (INPE), BR

University of Technology, China

Theodore D`Alessio, FL, USA, Maria Cristina Bean, FL, USA

Liliane Castro, Bibliotecária - CRB/8-6748, Taubaté, BR

Marcelo Siqueira Targa, UNITAU, BR

Tiago dos Santos Agostinho, UNITAU, BR

Luciana Gomes de Oliveira, UNITAU, BR

\section{Library catalog entry by Liliane Castro CRB/8-6748}

Revista Ambiente \& Água - An Interdisciplinary Journal of Applied Science / Instituto de Pesquisas Ambientais em Bacias Hidrográficas. Taubaté. v. 15, n.6 (2006) - Taubaté: IPABHi, 2020.

Quadrimestral (2006 - 2013), Trimestral (2014 - 2016), Bimestral (2017), Publicação Contínua a partir de Janeiro de 2018.

Resumo em português e inglês.

ISSN 1980-993X

1. Ciências ambientais. 2. Recursos hídricos. I. Instituto de Pesquisas Ambientais em Bacias Hidrográficas.

CDD - 333.705

CDU - (03)556.18 


\section{TABLE OF CONTENTS}

\section{COVER:}

The results presented in this figure are based on research aimed at investigating the correlation between the disinfection performance with the factors contact time $t$ and residual chlorine $C R$ in a long period of time ( 2 years) enabling to provide insights into the possible effects of the different seasons and related climatic conditions over this process. More specifically, the figure shows the experimental correlation between the efficiency ratio of $E$. coli removal by disinfection $(\mathrm{Eo} / \mathrm{E})$ with the product of chlorine residual with the contact time $\left(\mathbf{C}_{\mathbf{R}} . \mathbf{t}\right)$. Source: BONI, M.R. et al. Study of the performance of disinfection with sodium hypochlorite on a full-scale sewage treatment plant. Rev. Ambient. Água, Taubaté, vol. 15 n. 6, p. 1-8, 2020. doi:10.4136/ambi-agua.2652

\section{ARTICLES}

\begin{tabular}{|c|c|c|}
\hline 01 & $\begin{array}{l}\text { Extreme rainfall and IDF equations for Alagoas State, Brazil } \\
\text { doi:10.4136/ambi-agua.2544 } \\
\text { Álvaro José Back; Sabrina Baesso Cadorin; Sérgio Luciano Galatto }\end{array}$ & $1-10$ \\
\hline 02 & $\begin{array}{l}\text { Performance of slow sand filters in the after-treatment of effluent from Pernambuco state textile } \\
\text { center } \\
\text { doi:10.4136/ambi-agua.2586 } \\
\text { Alanna Maria do Nascimento Bezerra; Marcos Henrique Gomes Ribeiro; Artur Paiva Coutinho; } \\
\text { Ana Emília Carvalho de Gusmão da Cunha Rabelo; Elizabeth Amaral Pastich Gonçalves }\end{array}$ & $1-15$ \\
\hline $\mathbf{0 3}$ & $\begin{array}{l}\text { Ozonation as a pre-treatment of landfill leachate } \\
\text { doi:10.4136/ambi-agua.2592 } \\
\text { Leticia Tamara Hoffmann; Matheus Caneles Batista Jorge; Adriana Garcia do Amaral; } \\
\text { Milene Carvalho Bongiovani; Roselene Maria Schneider }\end{array}$ & $1-12$ \\
\hline 04 & $\begin{array}{l}\text { Biodegradation of nitroaromatic compounds in Red Water by white rot fungi Pleurotus ostreatus } \\
\text { and floridae } \\
\text { doi:10.4136/ambi-agua.2594 } \\
\text { Cristiane Patrícia Kist; Claudio Eduardo Scherer; Marlene Soares; Marcio Barreto Rodrigues }\end{array}$ & $1-11$ \\
\hline 05 & $\begin{array}{l}\text { Mixed greywater treatment for irrigation uses } \\
\text { doi:10.4136/ambi-agua.2599 } \\
\text { Eli Morales Rojas; Jesús Rascón; Lenin Quiñones Huatangari; Segundo Chavez Quintana; Manuel Oliva; } \\
\text { Manuel Emilio Milla Pino }\end{array}$ & $1-11$ \\
\hline 06 & $\begin{array}{l}\text { Polymer coating in soybean seed treatment and their relation to leaching of chemicals } \\
\text { doi:10.4136/ambi-agua.2602 } \\
\text { Eduardo José Ludwig; Ubirajara Russi Nunes; Osmar Damian Prestes; Lovane Klein Fagundes; } \\
\text { Tiéle Stuker Fernandes; Nathália Saibt }\end{array}$ & $1-10$ \\
\hline 07 & $\begin{array}{l}\text { Monitoring of fluoride in the public water supply using electrometric or colorimetric analyses } \\
\text { doi:10.4136/ambi-agua.2603 } \\
\text { Caio Luiz Lins-Candeiro; Karen Katlein Dolenkei; Luiz Renato Paranhos; Douglas Queiroz Santos; } \\
\text { Jaime Aparecido Cury; Juliana Pereira da Silva Faquim }\end{array}$ & $1-11$ \\
\hline 08 & $\begin{array}{l}\text { Coagulation Activity of the Seed Extract from Zygia cauliflora (WILLD.) KILLIP applied in } \\
\text { Water Treatment } \\
\text { doi:10.4136/ambi-agua.2611 } \\
\text { Julia Aoki Domingues; Nelson Consolin Filho; Luiz Augusto Gomes de Souza; } \\
\text { Flávia Vieira da Silva Medeiros }\end{array}$ & $1-12$ \\
\hline
\end{tabular}


Study of the performance of disinfection with sodium hypochlorite on a full-scale sewage treatment plant

09

doi:10.4136/ambi-agua.2652

Maria Rosaria Boni; Sabrina Copelli; Massimo Raboni

Medium-term projection for the National Hydro-Electrical System using wavelets

10 doi:10.4136/ambi-agua.2583

Francisco Wellington Martins da Silva; Cleiton da Silva Silveira; Antônio Duarte Marcos Junior; João Dehon de Araujo Pontes Filho

Physical fractions of organic matter and mineralizable soil carbon in forest fragments of the Atlantic Forest

11

doi:10.4136/ambi-agua.2601

Jefferson Matheus Barros Ozório; Jean Sérgio Rosset; Jolimar Antonio Schiavo;

Camila Beatriz da Silva Souza; Paulo Guilherme da Silva Farias; Naelmo de Souza Oliveira;

Roniedison da Silva Menezes; Eloi Panachuki

Application of a voltammetric enzymatic biosensor based on crude extract of Marasmiellus colocasiae for the detection of phenolic compounds in drinking water

12 doi:10.4136/ambi-agua.2610

Érica Aparecida Batista; Luane Ferreira Garcia; Antonio João Carvalho de Albuquerque;

Nara Ballaminut; Paulo Sérgio Scalize; Eric Souza Gil 


\begin{tabular}{|c} 
Ambiente \& Água - An Interdisciplinary Journal of Applied Science \\
ISSN 1980-993X - doi:10.4136/1980-993X \\
www.ambi-agua.net \\
E-mail: ambi.agua@gmail.com
\end{tabular}

\title{
Reviewers of Volume 15, 2020 of Revista Ambiente \& Água
}

\section{Scientific Reviewers}

\author{
doi:10.4136/ambi-agua.2607 \\ Nelson Wellausen Dias \\ Editor of Revista Ambiente \& Água \\ E-mail: ambi.agua@gmail.com
}

The list of reviewers who voluntarily dedicated part of their time to review submissions for Revista Ambiente \& Água's Volume 15, 2020 is presented in Table 1. This list includes manuscripts that were accepted and published in one of the six annual issues and also manuscripts submitted and rejected up to November 01, 2020. It may therefore include the names of reviewers that completed their evaluations between December, 2019 and November, 2020.

We are deeply indebted to all of them that voluntarily and anonymously devoted part of their time to support our journal and delivered an immense contribution to the quality of the published papers. We gratefully acknowledge their professional work and outstanding product.

Table 1. Ad Hoc Peer Reviewers that evaluated submissions for the 2020 edition of Revista Ambiente \& Água, Volume 15, n. 1, 2, 3, 4, 5, and 6.

Abdelbaset Sabry Mohamed El-Sorogy

Abdelkader Hamlat

Adalberto Benavides-Mendoza

Adelena Maia

Adriana Castreghini de Freitas Pereira

Adriane Martins de Freitas

Adriano Valentim Diotto

Agnes Keresztesi

Agostina Chiavola

Akeem Akinboro

Alejandro Alvarado-Lassman

Alexandros Stefanakis

Ali Lashkari

Aliakbar Mohammadi
King Saud University, Riyadh, Saudi Arabia

Université Amar Telidji de Laghouat, Laghouat, Algeria

Universidad Autónoma Agraria Antonio Narro, Saltillo, Coahuila, Mexico

Universidade Federal do Rio Grande do Norte (UFRN), Natal, RN, Brazil

Universidade Estadual de Londrina (UEL), Londrina, PR, Brazil

Universidade Tecnológica Federal do Paraná (UTFPR), Curitiba, PR, Brazil

Universidade Federal de Lavras (UFLA), Lavras, MG, Brazil

Sapientia University, Cluj Napoca, Romania

Sapienza Università di Roma, Roma, Italy

Ladoke Akintola University of Technology, Ogbomosho, Oyo, Nigeria

Technological Institute of Orizaba, Orizaba, Mexico

Technical University of Crete, Chania, Greece

Shiraz University of Technology, Fars Province, Shiraz, Iran

Neyshabur University Medical Sciences, Neyshabur, Iran 
Alisson Carraro Borges

Álvaro José Back

Amey Tilak

Amin Soltangheisi

Ana-Maria Stanescu

Andrea Waichman

Andrew Dean

Anshuman Singh

Antonio Teixeira de Matos

Aref Shokri

Argantonio Rodriguez Merino

Ariovaldo José da Silva

Aurora Santos López

Ayan Santos Fleischmann

Bahram Choubin

Basim Hussein Khudair Al-Obaidi

Beatriz Miguel

Bin Xu

Bruno Mantovanelli

Carlos Alexandre Borges Garcia

Carlos Díaz Delgado

Carlos Dias Pereira

Carlos Rico

Catarina Faggio

Claude Hammecker

Cosmas Nathanailides

Dagnija Lazdina

Daniel Mantovani

Daniele Torres Rodrigues

David Omole

Davoud Balarak
Universidade Federal de Viçosa (UFV), Viçosa, MG, Brazil

Empresa de Pesquisa Agropecuária e Extensão Rural de Santa Catarina (EPAGRI), Florianópolis, SC, Brazil Limerick Institute of Technology, Thurles, Ireland Lancaster University, Lancaster, United Kingdom

National Research and Development Institute for Soil Science, Agrochemistry and Environment Protection, Bucharest, Romania

Universidade Federal do Amazonas (UFAM), Manaus, AM, Brazil

Manchester Metropolitan University, Manchester, United Kingdom

Central Soil Salinity Research Institute, Karnal, Haryana, India

Universidade Federal de Minas Gerais (UFMG), Belo Horizonte, MG, Brazil

Islamic Azad University, Tabriz, Iran

Universidad de Sevilla, Sevilla, Andalucía, Spain

Universidade Estadual de Campinas (UNICAMP), Campinas, SP, Brazil

Universidad Complutense de Madrid, Madrid, Spain

Universidade Federal do Rio Grande do Sul (UFRGS), Porto Alegre, RS, Brazil

East-Azarbaijan Agricultural and Natural Resources Research and Education Center, Tehran, Iran

University of Baghdad, College of Engineering, Baghdad, Iraq

Universidad Politécnica de Cartagena, Murcia, Spain

Boston University, Boston, Massachusetts, United States

Universidade Federal de Santa Maria (UFSM), Santa Maria, RS, Brazil

Universidade Federal de Sergipe (UFS), Aracaju, SE, Brazil

Universidad Autónoma del Estado de México, Toluca, Estado de México, Mexico

Instituto Politécnico de Coimbra, Coimbra, Portugal

Universidad de Cantabria, Santander, Cantabria, Spain

Università degli Studi di Messina, Locri, Sicilia, Italy

Université de Lyon, Lyon, France

University of Ioannina, Ioannina, Greece

Latvian State Forest Research Institute "Silava",

Salaspils, Salaspils pilsēta, Latvia

Universidade Estadual de Maringá (UEM), Maringá, PR, Brazil

Universidade Federal do Piauí (UFPI), Teresina, PI, Brazil

Covenant University, Ota, Ogun, Nigeria

Zahedan University of Medical Sciences, Zahedan, Sistan And Baluchistan, Iran 
Deb Raj Aryal

Deepak Swami

Dirceu Silveira Reis Junior

Dunhai Li

Ebrahim Hadavi

Edris Hoseinzadeh

Eduardo Óscar Leidi Montes

Eko Praretyo Kuncoro

Elhadj Mokhtari

Elisangela Düsman

Elzbieta Zebek

Emilia Marques Brovini

Ergo Rikmann

Érica Simplício Souza

Ernesto Brugnoli

Estrella Nunez-Delicado

Everton Alves Rodrigues Pinheiro

Fabio de Oliveira Sanches

Farshid Ghanbari

Fazlollah Changani

Fernando Mainardi Fan

Fernando Ramos Martins

Fikret UstaoĞlu

Francesca Bosco

Francesco Sapino

Frank Onderi Masese

Fuat Özyonar

Germán San Lobon

Germário Araújo

Giordano Urbini

Grazyelle Sebrenski Silva
Consejo Nacional de Ciencia y Tecnologia, Villaflores, Mexico

Indian Institute Of Technology, Mandi, India

Universidade de Brasília (UnB), Brasília, DF, Brazil

Chinese Academy Of Agricultural Sciences, Wuhan, China

Islamic Azad University, Tabriz, Karaj, Iran

Tarbiat Modarres University, Tehran, Iran

Instituto de Recursos Naturales y Agrobiología de Sevilla, Sevilla, Spain

Airlangga University, Surabaya, Indonesia

Université Mohamed Boudiaf de M'sila, M'Sila,

Algeria

Universidade Tecnológica Federal do Paraná

(UTFPR), Francisco Beltrão, PR, Brazil

Uniwersytet Warminsko Mazurski Olsztynie, Olsztyn, Polonia

Universidade Federal de Juiz de Fora (UFJF), Juiz de Fora, MG, Brazil

University of Tartu, Tartu, Estonia

Universidade do Estado do Amazonas (UEA), Manaus, AM, Brazil

Universidad de la República, Montevideo, Uruguay

Universidad Católica San Antonio de Murcia, Guadalupe de Maciascoque, Murcia, Spain

Universidade Federal do Mato Grosso (UFMT), Cuiabá, MT, Brazil

Universidade Federal da Fronteira Sul (UFFS), Chapecó, SC, Brazil

Abadan School of Medical Sciences, Abadan, Khuzestan Province, Iran

Tehran University of Medical Sciences, Tehran, Iran

Universidade Federal do Rio Grande do Sul (UFRGS), Porto Alegre, RS, Brazil

Universidade Federal de São Paulo (UNIFESP), Santos, SP, Brazil

Giresun University, Giresun, Turkey

Politecnico di Torino, Torino, Italy

Universidad de Salamanca, Salamanca, Castilla y León, Spain

University Of Eldoret, Eldoret, Eldama Ravine, Kenya Cumhuriyet University, Sivas, Turkey

Universidade Federal de Goiás (UFG), Goiânia, GO, Brazil

Instituto Federal de Educação Ciências e Tecnologia do Ceará (IFCE), Fortaleza, CE, Brazil

Università degli studi dell'Insubria, Varese, Italy

Universidade Federal do Amazonas (UFAM), Manaus, AM, Brazil, Manaus, Brazil 
Guoqing Zhang

Hani Mansour

Hari Ram

Harikumar P.S.

Helder Pinheiro

Helena Nadais

Hüseyin Cengiz Yatmaz

Irvan Dahlan

Isabeli Pereira Bruno

Jaildo Santos Pereira

Jaime Lopes da Mota Oliveira

Jaime Portilla

Jalil Jaafari

Javier Tomasella

Jesus Mateo Lazaro

Jianguang Wen

João Bassin

Jonatas Valença

Jorge Luis Pinto Filho

José Antonio Gonzales-Perez

José Roberto Guimarães

Josyane Ronchail

Kathleen Aviso

Kirsty Carden

Lamine Diamão

Lei Su

Lekhendra Tripathee

Lucia D'Ambruoso

Luciano André Deitos Koslowski

Luiz Eduardo Vieira de Arruda
Chinese Academy Of Agricultural Sciences, Chaoyang District, Beijing, China

Southern Illinois University System, Giza, Egypt

Punjab Agricultural University, Ludhiana, Punjab, India

Centre for Water Resources Development and Management, Kozhikode, India

Universidade Federal do Pará (UFPA), Belém, PA, Brazil

Universidade de Aveiro, Aveiro, Portugal

Gebze Technical University, Gebze, Kocaeli, Turkey

Universiti Sains Malaysia, Nibong Tebal, Malaysia

Instituto Agronômico do Paraná (IAPAR), Londrina, PR, Brazil

Universidade Federal do Recôncavo da Bahia (UFRB), Cruz das Almas, BA, Brazil

Fundação Oswaldo Cruz (FIOCRUZ), Manguinhos, RJ, Brazil

Universidad de los Andes, Distrito Capital, Bogotá, Colombia

Tehran University of Medical Sciences, Tehran, Iran

Centro Nacional de Monitoramento e Alertas de Desastres Naturais (CEMADEN), Cachoeira Paulista, SP, Brazil

Universidad de Zaragoza, Zaragoza, Aragón, Spain

Chinese Academy Of Agricultural Sciences, Beijing, China

Univeridade Federal do Rio de Janeiro (UFRJ), Rio de Janeiro, RJ, Brazil

Universidade de Lisboa, Lisboa, Portugal

Universidade Federal Rural do Semi-Árido

(UFERSA), Mossoró, RN, Brazil

Instituto de Recursos Naturales y Agrobiología de Sevilla, Sevilla, Spain

Universidade Estadual de Campinas (UNICAMP), Campinas, SP, Brazil

Université Paris Diderot-Paris, Paris, France

De La Salle University Manila, Manila, Filipino

University of Cape Town, Rondebosch, South Africa

Université Cheikh Anta Diop de Dakar, Dakar, Senegal

East China Normal University, Minhang District, Shanghai, China

Lappeenranta Polytechnic University, Lappeenranta, Finland

University of the Witwatersrand, Johannesburg, South Africa

Universidade do Estado de Santa Catarina (UDESC), Joinville, SC, Brazil

Universidade Federal Rural do Semi-Árido

(UFERSA), Mossoró, RN, Brazil 
Luiz Ubiratan Hepp

M.G. Mostafa Amin

Madan Mohan Mahanty

Mahmoud Mohamed Fouad Hussein

Majid Mirzaei

Marcelo Rodrigues Bessa

Marcin Sidoruk

Marcin Wdowikowski

Marcio Mesquita

Marcos García-López

Marek Zivcak

Maria Cristina Cangussu

Marian Brestic

Marie-Noelle Pons

Mario Alberto Arzate-Cárdenas

Martin Thalheimer

Md. Mahmudul Hasan

Mehmet Sait

Mehmet Sener

Michel Brossard

Moctar Diaw

Mohammad Reza Khaleghi

Mohd Yawar Ali Khan

Moreno Toselli

Morsaline Billah

Muhammed Atamanalp

Muharren İnce

Mukesh Tiwari

Muzandu Kaampwe

Naseer Inuwa Duruminiya

Naunain Mehmood

Nguyen-Thi-Ngoc Anh

Nhamo Nhamo

Nilantha Hulugalle
Universidade Regional Integrada do Alto Uruguai e das Missões (URI), Erechim, RS, Brazil

Bangladesh Agricultural University, Mymensingh, Dhaka Division, Bangladesh

National Institute of Ocean Technology (NIOT), Chennai, Tamil Nadu, India

Ain shamas University, El-Abaseya, Egypt

University of Malaya, Kuala Lumpur, Malaysia

Universidade Federal do Paraná (UFPR), Curitiba, PR, Brazil

University of Warmia and Mazury, Olsztyn, WarmianMasurian, Poland

Institute of Meteorology and Water Management, Warszawa, Poland

Universidade Federal de Goiás (UFG), Goiânia, GO, Brazil

Universidad de Alicante, Alacant, Valencia, Spain

Slovak University of Agriculture, Nitra-Chrenová, Slovakia

Escola Politécnica da Universidade Federal da Bahia (UFBa), Salvador, BA, Brazil

Slovak University of Agriculture, Nitra-Chrenová, Slovakia

Université de Lorraine, Nancy, France

Universidad Autónoma de Aguascalientes, Aguascalientes, Mexico

Research Centre For Agriculture And Forestry Laimburg, Ora, Italy

University of Asia Pacific, Dhaka, Dhaka Division, Bangladesh

Ondokuz Mayis University, Samsun, Turkey

Namik Kemal University, Tekirdag, Turkey

Institut de Recherche pour le Developpement (IRD), Montpellier, France

Faculté Des Sciences Et Techniques, Dakar, Senegal

Islamic Azad University, Tabriz, Iran

King Abdulaziz University, Jeddah, Saudi Arabia

Università di Bologna, Bologna, Italy

Khulna University, Khulna, Khulna Division,

Bangladesh

Atatürk University, Erzurum, Turkey

Munzur University, Tunceli, Turkey

Anand Agricultural University, Anand, Gujarat, India

University of Zambia, Lusaka, Zambia

University of Malaysia, Kota Samarahan, Malaysia

University of Sargodha, Sargodha, Punjab, Pakistan

Hanoi University of Science and Technology, Hanoi, Viet Nam

Zimbabwe Open University, Harare, Zimbabwe

Australia's National University, Canberra, Australia 
Olatunde Dahunsi

Ozekele Ogbeide

Pablo Siles

Paulo Araquém Ramos Cairo

Paulo Cesar Sentelhas

Petri Papaphilipou

Pinalysa Cosma

Pooja Chadha

Priscilla Amaral

Quanjiu Wang

Ramesh Mathan

Rauf Foroutan

Rawaa Al-Isawi

Robert Szep

Roch Christian Johnson

Rodolfo Moreda Mender

Rutineia Tassi

Sabu Thomas

Sarva Mangala Praveena

Sebastiano Trevisani

Shagufta Kamal

Shakti P. C.

Shirish Sonawane

Simone Cardoso

Simone Maria Ribas Vendramel

Sreenivasa C. Ramaiahgari

Sudhir Kumar Singh

Suzymeire Baroni

Swastik Bhandari

Tahira Pirzada

Taofeeq Sholagberu Abdulkadir

Tiago Reis Dutra
Landmark University, Omu-Aran, Kwara, Nigeria

University of Benin, Benin City, Edo, Nigeria

International Center for Tropical Agriculture (CIAT), Managua, Nicaragua

Universidade Estadual do Sudoeste da Bahia (UESB), Vitória da Conquista, BA, Brazil

Universidade de São Paulo (USP), São Paulo, SP, Brazil

University of Cyprus, Nicosia, Cyprus

Università degli Studi di Bari, Bari, Puglia, Italy

Guru Nanak Dev University, Amritsar, Punjab, India

Univeridade Federal do Rio de Janeiro (UFRJ), Rio de Janeiro, RJ, Brazil

Northwest A\&F University, Yangling, Shaanxi, China

Bharathiar University, Coimbatore, Tamil Nadu, India

University of Tabriz, Tabriz, East Azerbaijan, Iran

University of Babylon, Babil, Iraq

Sapientia Hungarian University of Transylvania, Miercurea Ciuc, Romania

Université d'Abomey-Calavi, Cotonou, Benin

Centro Nacional de Monitoramento e Alertas de Desastres Naturais (CEMADEN), São José dos Campos, SP, Brazil

Universidade Federal de Santa Maria (UFSM), Santa Maria, RS, Brazil

Mahatma Gandhi University, Kottayam, Kerala, India

Putra University, Serdang, Selangor, Malaysia

Università Ca' Foscari Venezia, Venezia, Italy

Government College University Faisalabad,

Faisalabad, Punjab, Pakistan

University of Tsukuba, Ibaraki, Kanto, Japan

National Institute Of Technology, Warangal, Telangana, India

Universidade Federal de Juiz de Fora (UFJF), Juiz de Fora, MG, Brazil

Instituto Federal de Educação, Ciência e Tecnologia do Rio de Janeiro (IFRJ), Niterói, RJ, Brazil

National Institute for Environmental Health Sciences (NIEHS), Research Triangle Park, North Carolina, United States

Allahabad University, Allahabad, Uttar Pradesh, India Universidade Federal da Fronteira Sul (UFFS), Cerro Largo, RS, Brazil

Southern Illinois University, Carbondale, Illnois, United States

North Carolina State University, Raleigh, North Carolina, United States

University of Ilorin, Ilorin, Kwara, Nigeria

Instituto Federal de Educação, Ciência e Tecnologia do Norte de Minas Gerais (IFNMG), Salinas, MG, Brazil 
Touhidul Alam

Tugce Katipoglu-Yazan

Vanessa Bezerra de Menezes Oliveira

Vasant Wagh

Vernon S Somerset

Vilim Filipović

Vincenzo Torretta

Vinitha Ebenezer

Vladimir Razlutsky

Wilson Thau Lym Yong

Xiaoping Wang

Yaseen Ahmed Hamaamin

Younes Menni

Zhen $\mathrm{Hu}$
International Islamic University Chittagong (IIUC), Chattagam, Chittagong Division, Bangladesh

Institut national de la recherche agronomique (INRAE), Paris, France

Universidade Estadual Paulista "Júlio de Mesquita Filho (UNESP), São Carlos, SP, Brazil

Swami Ramanand Teerth Marathwada University, Nanded, Maharashtra, India

University of Cape Town, Bellville, South Africa

University of Zagreb, Zagreb, Croatia

Università degli Studi dell'Insubria, Como, Lombardia, Italy

Dalhousie University, Halifax, Nova Scotia, Canada

National Academy of Sciences of Belarus, Minsk, Belarus

Universiti Malaysia Sabah, Kota Kinabalu, Sabah, Malaysia

Nanjing University, Gulou, Jiangsu, China

University of Sulaimani, Sulaimani, Iraq

Université Abou Bekr Belkaid de Tlemcen, Tlemcen, Algeria

Shandong University, Qingdao, Shandong, China

Note: 1) Some of these reviewers evaluated more than one manuscript;

2) This list includes reviewers that evaluated submissions that were not accepted for publication, in addition to the ones published in 2020 .

According to the information presented in Table 2, 137 reviewers are from international institutions. This is an indication that our journal is gaining international relevance and dissemination.

Table 2. Number and type of institutions of reviewers that contributed to Volume 15, 2020.

\begin{tabular}{|c|c|c|c|c|c|c|}
\hline \multicolumn{5}{|c|}{ From Brazil } & \multicolumn{2}{|l|}{ From abroad } \\
\hline $\begin{array}{c}\text { Federal } \\
\text { Universities }\end{array}$ & $\begin{array}{c}\text { State } \\
\text { Universities }\end{array}$ & $\begin{array}{l}\text { State/Federal } \\
\text { Institutions }\end{array}$ & $\begin{array}{c}\text { National } \\
\text { private } \\
\text { Universities }\end{array}$ & $\begin{array}{l}\text { Municipal } \\
\text { Universities }\end{array}$ & $\begin{array}{l}\text { Reviewers from } \\
\text { international Institutions }\end{array}$ & Total \\
\hline 31 & 9 & 8 & 1 & 0 & 137 & 186 \\
\hline
\end{tabular}




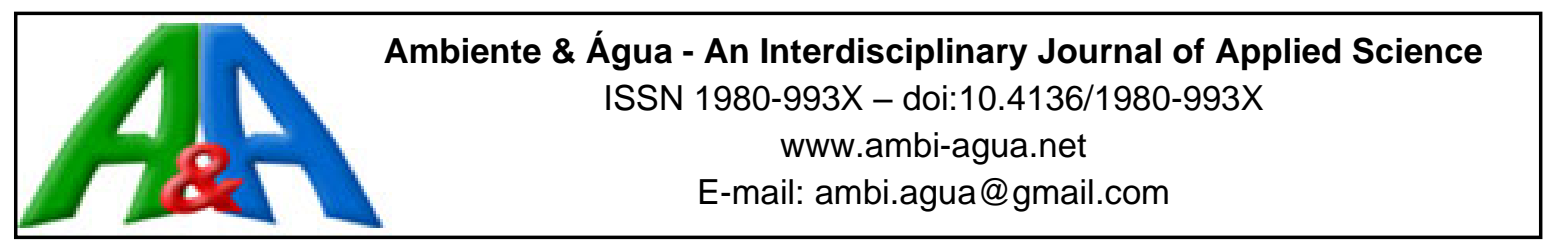

\title{
Extreme rainfall and IDF equations for Alagoas State, Brazil
}

\author{
ARTICLES doi:10.4136/ambi-agua.2544
}

Received: 17 Mar. 2020; Accepted: 11 Sep. 2020

\begin{abstract}
Álvaro José Back ${ }^{1 *}$; Sabrina Baesso Cadorin² ${ }^{\circledR}$; Sérgio Luciano Galatto ${ }^{3}$
${ }^{1}$ Estação Experimental de Urussanga. Empresa de Pesquisa Agropecuária e Extensão Rural de Santa Catarina (EPAGRI), Rodovia SC 108, km 353, nº 1563, CEP: 88840-000, Urussanga, SC, Brazil.

${ }^{2}$ Programa de Pós-Graduação em Ciências Ambientais. Universidade do Extremo Sul Catarinense (UNESC), Avenida Universitária, $\mathrm{n}^{\circ}$ 1105, CEP: 88806-000, Criciúma, SC, Brazil. E-mail: bcadorin.sabrina@gmail.com ${ }^{3}$ Instituto de Pesquisas Ambientais e Tecnológicas. Centro de Pesquisa e Estudos Ambientais. Universidade do Extremo Sul Catarinense (UNESC), Rodovia Governador Jorge Lacerda, km 4,5, nº 3800, CEP: 88807-400,

Criciúma, SC, Brazil. E-mail: sga@unesc.net

*Corresponding author. E-mail: ajb@epagri.sc.gov.br
\end{abstract}

\begin{abstract}
Intensity-duration-frequency (IDF) equations have important applications in several engineering areas such as urban drainage designs, hydrological modeling, and soil conservation projects. This study analyzes the annual maximum series and fits IDF equations for 44 rainfall stations in Alagoas State, Brazil. We adjusted parameters of the Gumbel distribution (GD) and the Generalized Extreme Value (GEV) distribution. The fitting of the observed data to the probability distributions, as well as the selection of the best distribution, were based on the Kolmogorov-Smirnov and Anderson-Darling tests at a 5\% significance level. The GEV distribution with parameters obtained by the L-moments method was considered the best in $73 \%$ of rainfall stations. The estimated IDF equations showed a good fit, with determination coefficients above 0.991 . The maximum rainfall intensities have spatial variation following the climatic zones of the state. The fitted equations allow estimating rainfall intensities from 5 minutes to 24 hours with a return period of 2 to 100 years, and standard error of less than $6.83 \mathrm{~mm} \mathrm{~h}^{-1}$.
\end{abstract}

Keywords: drainage, probabilities, water resources.

\section{Chuvas intensas e equações IDF para o estado de Alagoas, Brasil}

\section{RESUMO}

As equações IDF tem importante aplicação em diversas áreas da engenharia como nos projetos de drenagem urbana, na modelagem hidrológica e em projetos de conservação do solo. Este trabalho teve como objetivo analisar as séries de máximas anuais e ajustar as equações IDF para 44 estações pluviométricas do estado de Alagoas, Brasil. Foram ajustados os parâmetros da distribuição de Gumbel e da distribuição Generalizada de Valores Extremos. A avaliação da aderência dos dados observados às distribuições de probabilidade bem como a seleção da melhor distribuição foi baseada nos testes de Kolmogorov-Smirnov e AndersonDarling, ao nível de significância de 5\%. A distribuição GEV com parâmetros obtidos pelo método dos L-Momentos foi considerada a melhor em $73 \%$ das estações pluviométricas. As equações IDF estimadas apresentaram um bom ajuste, com coeficientes de determinação acima de 0,991 . As intensidades de chuvas máximas têm variação espacial acompanhando as zonas 
Álvaro José Back et al.

climáticas do estado. As equações ajustadas permitem estimativa da intensidade da chuva com duração de 5 minutos a 24 horas e período de retorno de 2 a 100 anos, com erro padrão de estimativa inferior $6,83 \mathrm{~mm} \mathrm{~h}^{-1}$.

Palavras-chave: drenagem, probabilidades, recursos hídricos.

\section{INTRODUCTION}

Excessive rainfall can cause agricultural losses, soil erosion, and flooding. In addition to causing material damage, these events represent a major risk to life, especially in urban areas. Thus, knowledge about extreme rainfall in a given location has great application in urban and agricultural planning, besides being used in environmental risk analysis, water infrastructure projects, irrigation, and dimensioning of engineering drawings (Deng et al., 2017; Coelho Filho et al., 2017).

To characterize extreme rainfall, one must know the intensity, duration of the event, and the frequency of occurrence, which can be represented by intensity-duration-frequency (IDF) curves and equations (Silveira, 2016). These equations have great application in the hydrological dimensioning of urban drainage structures, in hydrological models for flow estimation, and in agricultural drainage and soil conservation (Marra et al., 2017; Ouali and Cannon, 2018).

Intensity-duration-frequency equations are determined using traditional methods based on data from rainfall stations (Martins et al., 2017; Tfwala et al., 2017). In the absence or scarcity of long data series, information from rainfall stations is gathered, and the maximum 1-day rainfall is clipped to shorter rainfall events, thus allowing the fitting of equations (Penner and Lima, 2016; Rangel and Hartwig, 2017; Dias and Penner, 2019). Some studies assess the possibility of using satellite or radar observations to obtain IDF equations (Marra et al., 2017).

Mirzaei et al. (2014) claim that is important to assess the uncertainties related to extreme rainfall estimates and to propagate those uncertainties into design decisions and risk assessment, and point out that uncertainty in depth-duration-frequency curves is usually disregarded in the view of difficulties associated in assigning a value to it. Mirzaei et al. (2015) investigated uncertainties incorporated in the distribution function of the series of annual maximum daily rainfall.

There are different statistical distributions of extreme events that can be used to fit a set of hydrological data. Among them is Gumbel, which is the most used for fitting data in studies of extreme rainfall (Gonçalves et al., 2019; Petrucci and Oliveira, 2019). Another distribution that has been shown to be quite adequate to represent extreme natural events such as heavy rainfall is the Generalized Extreme Value (GEV) distribution (Quadros et al., 2011; Tfwala et al., 2017). Olofintoye et al. (2009) point out that many statistical distributions can be applied to describe extreme annual rainfall events in a given location. However, choosing the appropriate model is one of the biggest problems in engineering practice, as there is no general agreement on which distribution or distributions to use in the analysis of extreme rainfall frequency. The selection of the appropriate model depends mainly on the characteristics of the available rainfall data for a particular station. That is why it is necessary to evaluate several distributions to find the model that allows obtaining the best extreme rainfall estimates.

In Alagoas State there is a lack of information on IDF equations (Dias and Penner, 2017). Thus, the present study analyzes the maximum annual rainfall and determines IDF equations in 44 rainfall stations distributed throughout Alagoas State, Brazil.

\section{MATERIALS AND METHODS}

Alagoas State is bathed by the Atlantic Ocean and borders the states of Pernambuco,

Rev. Ambient. Água vol. 15 n. 6, e2544 - Taubaté 2020 
Sergipe, and Bahia. The state is located between latitudes $8^{\circ} 54^{\prime} 57^{\prime \prime} \mathrm{S}$ and $9^{\circ} 19^{\prime} 50^{\prime \prime} \mathrm{S}$ and longitudes $35^{\circ} 09^{\prime} 08^{\prime \prime} \mathrm{W}$ and $38^{\circ} 13^{\prime} 38^{\prime \prime} \mathrm{W}$. The relief is divided into three major types, starting from east to west through the coastal plain, followed by the tablelands region, and the plateau that corresponds to most of the Alagoas territory. According to Barros et al. (2012), the annual rainfall averages in Alagoas State vary from 2,000 mm, on the coast, to $400 \mathrm{~mm}$ in the hinterlands (Sertão). These values gradually decrease from east to west.

Climatic variation throughout the state is quite significant. According to the Köppen climate classification, Alagoas State is divided into four zones. There is the occurrence of humid tropical climate (Ams) and semi humid tropical climate (As) in the most coastal region of the state, which corresponds to the forest zone, the most humid part of the Agreste region, and the coast. Such climates are characterized by abundant rains throughout the year and a well-defined dry season. To the west of Alagoas, in the Agreste and Sertão, climatic classification comprises the driest types, with a hot semi arid climate (BSsh), in which evaporation exceeds rainfall. There is also the presence of As climate in a small area northwest of the state (Barros et al., 2012).

The study included rainfall data from 44 rainfall stations located in Alagoas State, belonging to the Hydrological Network of the National Water Agency (ANA). We selected stations that presented at least 20 years of data. Table 1 contains the stations used, their respective coordinates, historical series, and climate data. Figure 1 shows the spatial distribution of these stations.

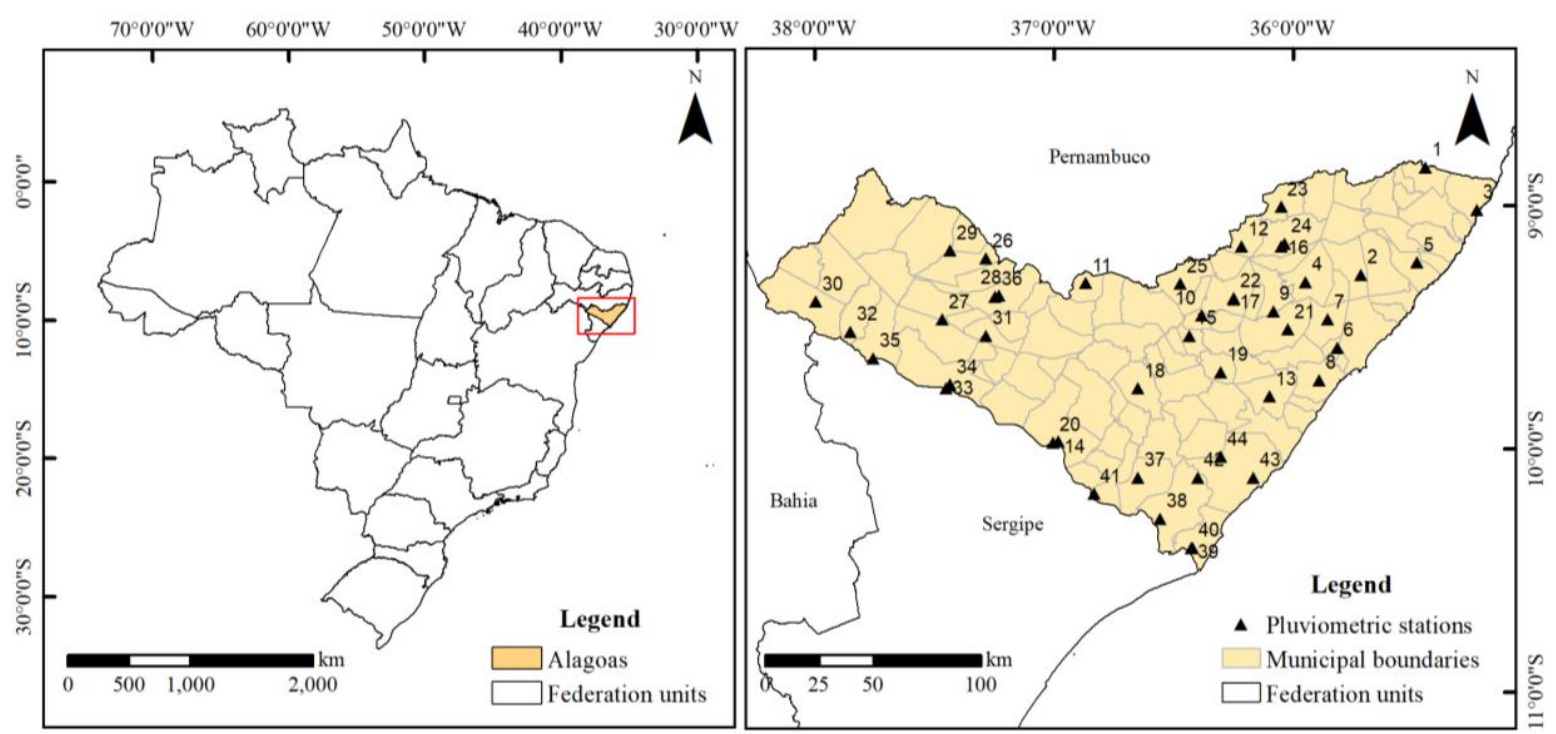

Figure 1. Location map of the rainfall stations used.

To analyze the historical series of extreme rainfall data, we used the Gumbel distribution (GD) (Type I distribution of extremes) and the Generalized Extreme Value (GEV) distribution, whose probability density functions (PDFs) are given, respectively, by Equations 1 and 2:

$$
\begin{aligned}
& f(x)=\frac{1}{\alpha} \operatorname{Exp}\left[-\frac{X-\beta}{\alpha}-\left(-\frac{X-\beta}{\alpha}\right)\right] \\
& f(x)=\frac{1}{\alpha}\left[1-k\left(\frac{X-\beta}{\alpha}\right)\right]^{\left(\frac{1}{k-1}\right)} \operatorname{Exp}\left\{-\left[1-k\left(\frac{X-\beta}{\alpha}\right)\right]^{\left(\frac{1}{k}\right)}\right\}
\end{aligned}
$$

Where $\mathrm{x}$ is the maximum annual daily rainfall; $\alpha, \beta$, and $\mathrm{k}$ are parameters of the probability distribution (De Alcântara et al., 2019). 
Table 1. Location and data of the selected stations.

\begin{tabular}{|c|c|c|c|c|c|c|c|}
\hline No. & Code & City & $\begin{array}{l}\text { Latitude } \\
\quad\left({ }^{\circ} \mathbf{S}\right)\end{array}$ & $\begin{array}{c}\text { Longitude } \\
\left({ }^{\circ} \mathbf{W}\right)\end{array}$ & Period & No. years & Climate \\
\hline 1 & 835139 & Jacuípe & 8.8419 & 35.4475 & $1990-2018$ & 29 & Am \\
\hline 2 & 935001 & Flexeiras & 9.2833 & 35.7167 & $1963-2000$ & 31 & As \\
\hline 3 & 935010 & Maragogi & 9.0167 & 35.2333 & $1963-1991$ & 26 & Am \\
\hline 4 & 935012 & Murici & 9.3136 & 35.9497 & $1963-2018$ & 53 & As \\
\hline 5 & 935013 & Passo de Camaragibe & 9.2333 & 35.4833 & $1957-1991$ & 34 & Am \\
\hline 6 & 935023 & Satuba & 9.5833 & 35.8167 & 1963-1991 & 28 & Am \\
\hline 7 & 935056 & Rio Largo & 9.4675 & 35.8564 & $1990-2018$ & 27 & As \\
\hline 8 & 935057 & Marechal Deodoro & 9.7164 & 35.8917 & $1991-2018$ & 28 & Am \\
\hline 9 & 936014 & Capela & 9.4333 & 36.0833 & $1963-1988$ & 26 & As \\
\hline 10 & 936031 & Mar Vermelho & 9.4500 & 36.3833 & 1963-1994 & 30 & As \\
\hline 11 & 936032 & Palmeira dos Índios & 9.3167 & 36.8667 & 1963-1989 & 26 & As \\
\hline 12 & 936045 & Santana do Mundaú & 9.1667 & 36.2167 & $1963-2000$ & 34 & As \\
\hline 13 & 936048 & São Miguel Dos Campos & 9.7833 & 36.1000 & $1921-1984$ & 61 & As \\
\hline 14 & 936051 & Traipu & 9.9667 & 36.9833 & 1946-1998 & 49 & As \\
\hline 15 & 936052 & Tanque D'arca & 9.5333 & 36.4333 & $1963-2000$ & 32 & As \\
\hline 16 & 936053 & União dos Palmares & 9.1667 & 36.0500 & 1913-1991 & 71 & As \\
\hline 17 & 936057 & Viçosa & 9.3833 & 36.2500 & $1913-1989$ & 74 & As \\
\hline 18 & 936066 & Arapiraca & 9.7500 & 36.6500 & 1964-1991 & 24 & As \\
\hline 19 & 936070 & Anadia & 9.6836 & 36.3036 & 1913-1987 & 72 & As \\
\hline 20 & 936076 & Traipu & 9.9728 & 37.0033 & $1973-2018$ & 41 & As \\
\hline 21 & 936110 & Atalaia & 9.5072 & 36.0233 & $1990-2018$ & 28 & As \\
\hline 22 & 936111 & Viçosa & 9.3792 & 36.2492 & $1990-2018$ & 28 & As \\
\hline 23 & 936112 & São José da Laje & 9.0042 & 36.0511 & $1991-2018$ & 28 & As \\
\hline 24 & 936113 & União dos Palmares & 9.1544 & 36.0358 & $1991-2018$ & 28 & As \\
\hline 25 & 936115 & Quebrangulo & 9.3192 & 36.4731 & $1991-2010$ & 20 & As \\
\hline 26 & 937004 & Poço das Trincheiras & 9.2167 & 37.2833 & 1921-1989 & 64 & As \\
\hline 27 & 937005 & Santana do Ipanema & 9.4667 & 37.4667 & 1964-1994 & 28 & As \\
\hline 28 & 937006 & Santana do Ipanema & 9.3672 & 37.2292 & 1913-1991 & 69 & As \\
\hline 29 & 937012 & Canapi & 9.1833 & 37.4333 & $1938-1991$ & 50 & As \\
\hline 30 & 937013 & Delmiro Gouvéia & 9.3928 & 37.9942 & $1937-2018$ & 77 & BSh \\
\hline 31 & 937016 & Olho D’água das Flores & 9.5333 & 37.2833 & 1963-1989 & 25 & As \\
\hline 32 & 937017 & Olho D’água do Casado & 9.5167 & 37.8500 & 1963-1991 & 29 & As \\
\hline 33 & 937018 & Pão de Açúcar & 9.7486 & 37.4497 & $1982-2018$ & 36 & BSh \\
\hline 34 & 937019 & Pão de Açúcar & 9.7333 & 37.4333 & 1913-1985 & 63 & BSh \\
\hline 35 & 937023 & Piranhas & 9.6261 & 37.7561 & $1935-2018$ & 73 & BSh \\
\hline 36 & 937032 & Santana do Ipanema & 9.3728 & 37.2453 & 1979-2018 & 36 & As \\
\hline 37 & 1036003 & Igreja Nova & 10.1167 & 36.6500 & 1964-1999 & 32 & As \\
\hline 38 & 1036005 & Penedo & 10.2850 & 36.5564 & $1935-2018$ & 82 & As \\
\hline 39 & 1036007 & Piaçabuçú & 10.4064 & 36.4261 & $1929-2018$ & 80 & As \\
\hline 40 & 1036008 & Piaçabuçú & 10.4053 & 36.4219 & $1929-2000$ & 60 & As \\
\hline 41 & 1036009 & Porto Real do Colégio & 10.1833 & 36.8333 & 1913-1991 & 74 & As \\
\hline 42 & 1036011 & Coruripe & 10.1167 & 36.4000 & $1963-1991$ & 27 & As \\
\hline 43 & 1036013 & Coruripe & 10.1167 & 36.1667 & $1937-1984$ & 45 & As \\
\hline 44 & 1036062 & Coruripe & 10.0314 & 36.3039 & $1990-2018$ & 27 & As \\
\hline
\end{tabular}

The parameters of the Gumbel distribution were estimated using the Moments (MM), Maximum Likelihood (MLM), and L-moments (MML) methods (Naghettini and Pinto, 2007), in addition to the method proposed by Chow (CH) (Back and Bonetti, 2014). The parameters of the GEV distribution were adjusted by the Moments (MM) and L-moments (MML) methods (Naghettini and Pinto, 2007).

Following De Alcântara et al. (2019), two tests were used to analyze the fitting to the distribution: Kolmogorov-Smirnov (KS) and Anderson-Darling (AD), considering the ranking of distributions and the respective methods of estimating parameters. The distribution with the 
lowest sum of the ranks of the two tests was selected.

Using the selected distribution for each data series, the values of maximum daily rainfall with return periods of $2,5,10,15,25,50$, and 100 years were determined. The breakdown of daily rainfall into shorter duration rainfall followed the methodology proposed by CETESB (1986), estimating maximum rainfall intensities for 5, 10, 15, 20, 25, 30, 60, 360, 720, and 1440 minutes.

With the values obtained from maximum rainfall intensities for different durations and return times, we determined the parameters of the Equation 3 that expresses IDF:

$$
I=\frac{K T^{m}}{(t+b)^{n}}
$$

Where: $\mathrm{I}$ is the average maximum rainfall intensity $\left(\mathrm{mm} \mathrm{h}^{-1}\right) ; \mathrm{K}, \mathrm{m}, \mathrm{b}, \mathrm{n}$ are the coefficients to be fitted; $\mathrm{T}$ is the return period (years); $\mathrm{t}$ is the rainfall duration (minutes).

To fit the Equation 4, we minimized the standard error (RMSE), expressed by:

RMSE $=\sqrt{\frac{\sum_{\mathrm{j}=1}^{\mathrm{n}}\left(\mathrm{G}_{\mathrm{T}}^{\mathrm{t}}-\mathrm{I}_{\mathrm{T}}^{\mathrm{t}}\right)^{2}}{\mathrm{n}}}$

With the IDF equations obtained for each station, we determined rainfall intensity for different durations $(15,30$, and 60 minutes, and maximum daily rainfall with a 10 -year return period). To represent the spatial distribution of extreme rainfall, data were interpolated in ArcGIS 10.3 software using the ordinary kriging method with spherical model.

\section{RESULTS AND DISCUSSION}

For all data series, neither GD nor GEV distributions were rejected by the KS and AD adhesion tests. Although all distributions were adequate, the one with the best adherence was chosen (Table 2). In general, the GEV distribution showed better results, with this distribution being chosen for approximately $80 \%$ of stations. The GEV distribution obtained by the Lmoments method was highlighted with the best fitting in $32(73 \%)$ historical series. The Gumbel distribution is widely used for maximum annual rainfall (Ottero et al., 2018; Mistry and Suryanarayana, 2019). Notwithstanding, there are studies indicating that the GEV distribution has been shown to be superior to the Gumbel distribution (Beskow et al., 2015; Namitha and Vinothkumar, 2019).

Table 2 also presents the values of the coefficients of the IDF equation fitted for each station, the standard error values, and the coefficients of determination $\left(\mathrm{R}^{2}\right)$. For all stations, correlation coefficients greater than 0.991 and RMSE values ranging from 1.94 to $6.82 \mathrm{~mm} \mathrm{~h}^{-1}$ were obtained. Sabino et al. (2020) evaluated the fitting of the IDF equation for 14 rainfall stations in Mato Grosso State. The authors obtained a correlation coefficient $\left(\mathrm{R}^{2}\right)$ ranging from 0.8665 to 0.9596 , and RMSE ranging from 8.40 to $15.69 \mathrm{~mm} \mathrm{~h}^{-1}$. These data show the good quality of the fitting of IDF equations for Alagoas State.

The K coefficient values ranged from 268.5 to 1107.4 , and the $\mathrm{m}$ coefficient values ranged from 0.092 to 0.324 . Moreover, $b$ values approached 9.19 for all rainfall stations, and the $n$ coefficient values were equal to 0.706 . Other studies have already reported values practically constant for parameters $\mathrm{b}$ and $\mathrm{n}$ in fitting the coefficients of the IDF equation (Caldeira et al., 2015; Souza et al., 2012). Sabino et al. (2020) fitted IDF equations for 14 rainfall stations in Mato Grosso State and also observed a higher coefficient of variation in coefficients $\mathrm{K}$ and $\mathrm{b}$.

The $\mathrm{K}$ parameter is directly proportional to the rainfall intensity. The places where the highest values of this parameter were found coincide with the regions with the highest rainfall values, corresponding to the eastern/coastal region of tropical climate. In turn, the lowest $\mathrm{K}$ 
values are observed in the interior of the state, since in this region there is a dry climate. Therefore, there are coincidences with the characteristics of the Köppen climate classification, as already noted by Silva and Oliveira (2017).

Table 2. Coefficients of the fitted IDF equation with the respective RMSE and $\mathrm{R}^{2}$ values.

\begin{tabular}{|c|c|c|c|c|c|c|c|c|c|c|}
\hline \multirow{2}{*}{ No. } & \multirow{2}{*}{ Distribution } & \multicolumn{3}{|c|}{ Parameter } & \multicolumn{4}{|c|}{ Coefficient of the IDF equation } & \multirow{2}{*}{ RMSE } & \multirow{2}{*}{$\mathbf{R}^{2}$} \\
\hline & & $\alpha$ & $\beta$ & $\mathbf{k}$ & $\mathbf{K}$ & m & b & $\mathbf{n}$ & & \\
\hline 1 & MV & 048 & 74.2 & - & 742.1 & & 9. & 5 & 3.15 & 0.9975 \\
\hline 2 & GEV-MML & 33.24 & & 0.278 & 992.5 & & & & & \\
\hline 3 & GEV-MML & 39.09 & 67.30 & 0.189 & 815.1 & & 9 & & & 9910 \\
\hline 4 & GEV-MML & 23.18 & 68.09 & 0.007 & 704.9 & & 9.19 & 0.706 & 3.75 & 0.9966 \\
\hline 5 & GEV-MML & 40.27 & 80.62 & & 937.9 & & & & & \\
\hline 6 & GEV-MML & 39.62 & 100.59 & 0.211 & 1107.4 & 0.142 & 9.19 & 0.706 & 6.49 & 0.9942 \\
\hline 7 & GEV-MML & 24.13 & 80.03 & -0.243 & 734.9 & 0.282 & 9.19 & 0.706 & 2.81 & 0.9991 \\
\hline 8 & GEV-MM & 26.83 & 93.82 & 0.143 & 968.7 & & & & 4.27 & .9965 \\
\hline 9 & GD-CH & .049 & 64.67 & - & 660.6 & & 9.19 & 0.706 & 3.27 & 0.9970 \\
\hline 10 & GEV- & & & & & & & & & \\
\hline 11 & GEV & 17.35 & 47.09 & 0 & 497.2 & & & & 2.88 & 0.9960 \\
\hline 12 & GEV-MML & 18.21 & 63.85 & -0.020 & 637.3 & 0. & 9.19 & 0.706 & 2.77 & 0.9976 \\
\hline 13 & GEV-MML & 17.76 & & -0.093 & 656.9 & & & 06 & 2.44 & \\
\hline 14 & GD-CH & 0.053 & 42.69 & - & 466.8 & & 9.19 & 0.706 & 3.27 & 0.9952 \\
\hline 15 & GEV-MML & 25.10 & 66.02 & 0.460 & 730.3 & & 9.19 & 0.706 & 3.62 & 0.9943 \\
\hline 16 & GEV & 23.50 & & & 569.6 & & & & & \\
\hline 17 & GEV & 16.96 & 60.53 & -0.2 & 561.9 & & 9.19 & 0.706 & 2.03 & \\
\hline 18 & & & & & & & & & & \\
\hline 19 & GEV-MML & 15.44 & 60.88 & 0.007 & 602.7 & & 9. & 06 & 2.31 & 978 \\
\hline 20 & GD-CH & 0.064 & 38.28 & - & 411.0 & 0 & & 0.706 & 2.67 & 0.9956 \\
\hline 21 & GEV- & 3 & 59.51 & .026 & 702.1 & & & 06 & 6.23 & \\
\hline 22 & GEV-MML & 18.20 & 51.53 & -0.069 & 525.8 & & 9.19 & 0.706 & 2.88 & 971 \\
\hline 23 & GD-MMV & & & - & & & & & 3.92 & \\
\hline 24 & GEV & 09 & & 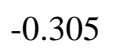 & & & 9 & 06 & 1.96 & 994 \\
\hline 25 & MML & 20.41 & 56 & 0 & 0 & & & 06 & 5 & 0.9951 \\
\hline 26 & & & & & & & & & & \\
\hline 27 & GEV-MML & 11.35 & & -0.116 & 268.5 & & & 0.706 & 1. & 0.9965 \\
\hline 28 & GEV-MML & 20.34 & & & & & & & 3.43 & \\
\hline 29 & IML & 12.53 & 6 & 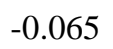 & & & 9. & 06 & 1.98 & 0.9971 \\
\hline 30 & GEV-MML & 20.28 & 50.05 & -0.0 & & 0 & & 0.706 & & 0.9957 \\
\hline 31 & & & & & & & & & & \\
\hline 32 & GEV-MML & & 40.10 & -0.103 & & & & 0.706 & & 0.9943 \\
\hline 33 & GEV-MML & 16.15 & & 0.004 & & & & 0.706 & 2.70 & 0.9960 \\
\hline 34 & GD-MMV & 0.048 & 52.10 & - & .5 & 5 & 9.20 & 0.706 & 3.48 & 0.9958 \\
\hline 35 & GEV-MML & 20.24 & 42.74 & -0.045 & 471.3 & 0.239 & 9.20 & 0.706 & 3.58 & 0.9953 \\
\hline 36 & GEV-MM & 18.60 & & & & & 9.19 & 0.706 & 3.18 & 0.9945 \\
\hline 37 & GEV-MML & 22.43 & 61.15 & 0.130 & 657.6 & 0.157 & 9.20 & 0.706 & 3.71 & 0.9952 \\
\hline 38 & GEV-MML & 23.91 & 71.38 & 0.044 & 742.8 & 0.174 & 9.19 & 0.706 & 3.88 & 0.9963 \\
\hline 39 & GEV-MML & & & & & & & & & \\
\hline 40 & GD-MM & 0.038 & & - & 627.0 & 0.218 & 9.19 & 0.706 & 4.57 & 0.9949 \\
\hline 41 & GD-MMV & 0.047 & & - & 570.6 & 0.206 & 9.19 & 0.706 & 3.63 & 0.9957 \\
\hline 42 & GD-MMV & 0.040 & 78.50 & - & 800.2 & 0.183 & 9.19 & 0.706 & 3.92 & 0.9970 \\
\hline 43 & GEV-MML & 30.94 & 82.40 & -0.076 & 850.0 & 0.228 & 9.20 & 0.706 & 5.00 & 0.9969 \\
\hline 44 & GEV-MM & 29.32 & 72.39 & 0.035 & 781.2 & 0.194 & 9.19 & 0.706 & 4.98 & 0.9953 \\
\hline
\end{tabular}

The fitting of IDF equations allowed estimating rainfall intensities for 15, 30, and 60 minutes with a 10-year return time, in addition to the maximum 1-day rainfall, using kriging to interpolate the data (Figure 2). The highest intensities occur on the coast, decreasing from east to west. Knowledge of IDF relationships, especially in places where hydrological monitoring 
is scarce, is an important tool for urban, agricultural, and environmental planning. Several engineering areas demand information about extreme rainfall, such as power generation, dams, civil construction, and urban drainage.
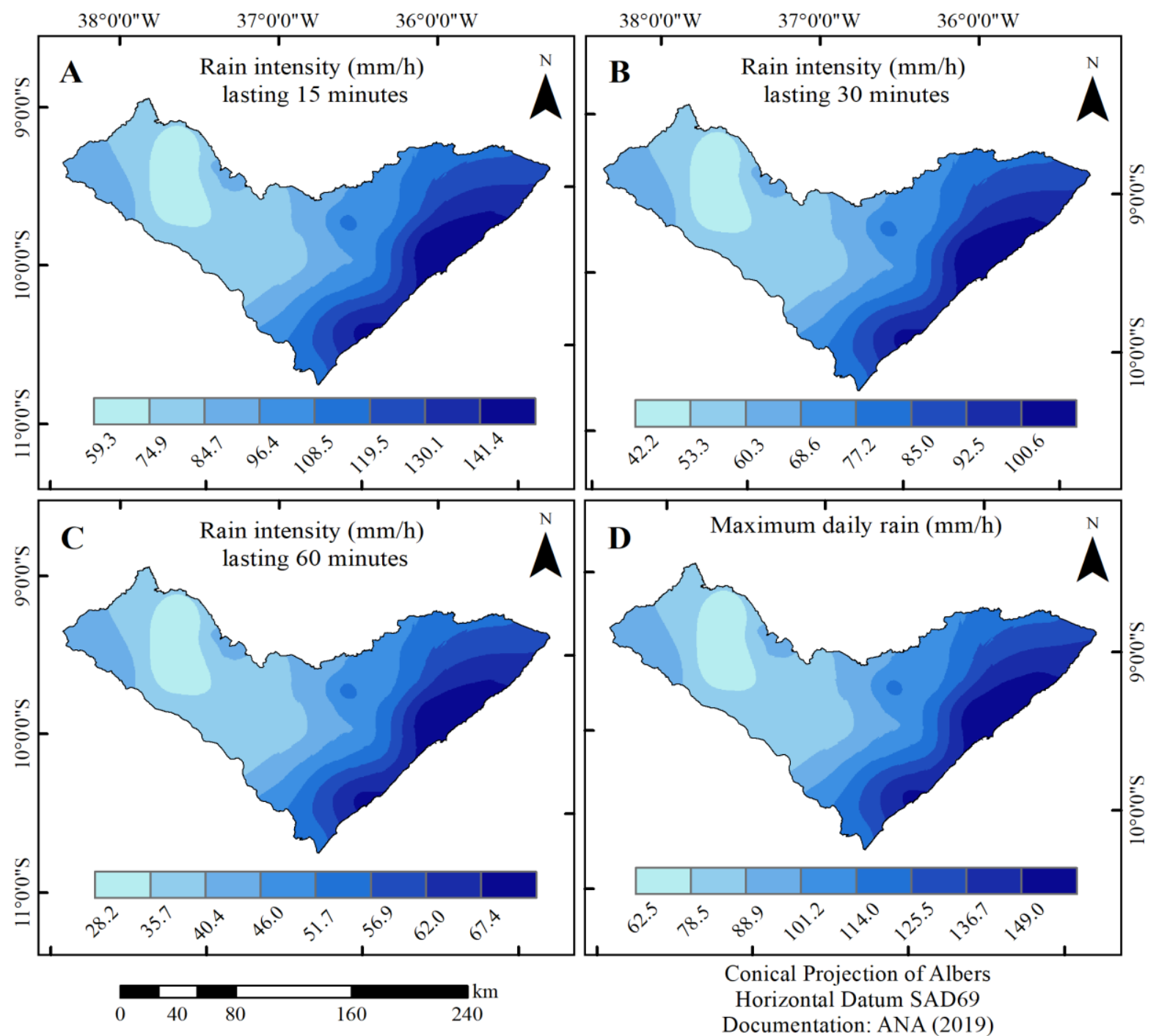

Figure 2. Rainfall intensity $\left(\mathrm{mm} \mathrm{h}^{-1}\right)$ for different durations with a 10-year return period, and maximum 1-day rainfall.

There is a marked spatial variation in maximum rainfall intensity in Alagoas State. Knowledge of this variation in rainfall intensity is important for planning water resource management actions as well as for soil conservation and engineering projects. The 5-minute rainfall intensity is used in the dimensioning of gutters to capture rainwater (Back and Bonetti, 2014). For soil conservation and gradient terracing, it is common to use the 15-minute rainfall intensity and a 10-year return period (De Maria et al., 2016). For level terraces, the maximum 1-day rainfall intensity and a 10-year return period is recommended. These values can be obtained from the IDF equations established for the rainfall stations in Alagoas (Table 2). The maximum 30-minute rainfall intensity is used as an indicator of the rainfall erosive potential. Therefore, Figure 2 indicates the locations with the greatest rainfall erosive potential in Alagoas State.

\section{CONCLUSIONS}

Alagoas' climate is quite varied, with tropical climate to the east and dry climate to the 
west. The highest averages of maximum annual rainfall coincide with the regions of tropical climate.

The series of maximum annual rainfall showed good fitting to Gumbel and GEV distributions, all of which were approved by the Kolmogorov-Smirnov and Anderson-Darling adhesion tests.

The GEV distribution with parameters obtained by the L-moments method was considered the best in $73 \%$ of rainfall stations.

The estimated IDF equations showed a good fit, with determination coefficients above 0.991. These equations allow estimating rainfall intensity from 5 minutes to 24 hours with a return period of 2 to 100 years, and standard error of $6.822 \mathrm{~mm} \mathrm{~h}^{-1}$.

There is a marked spatial variation in maximum rainfall intensity in Alagoas State, showing the need for hydrological studies addressing each climatic region of the state.

\section{REFERENCES}

BACK, Á. J.; BONETTI, A. V. Chuva de projeto para instalações prediais de águas pluviais de Santa Catarina. Revista Brasileira de Recursos Hídricos, v. 19, n. 4, p. 260-267, 2014. https://dx.doi.org/10.21168/rbrh.v19n4.p260-267

BARros, A. H. C.; ARAÚJO, J. C. F.; SILVA, A. B.; SANTIAGO, G. A. C. F. Climatologia do Estado de Alagoas. Dados eletrônicos. Recife: Embrapa Solos, 2012. 32 p. (Boletim de Pesquisa e Desenvolvimento).

BESKOW, S.; CALDEIRA, T. L.; MELLO, C. R.; FARIA, L. C.; GUEDES, H. A. S. Multiparameter probability distributions for heavy rainfall modeling in extreme southern Brazil. Journal of Hydrology: Regional Studies, 4B, p. 123-133. 2015. https://dx.doi.org/10.1016/j.ejrh.2015.06.007

CALDEIRA, T. L.; BESKOW, S.; MELLO, C. R. de; VARGAS, M. M., GUEDES, H. A. S.; FARIA, L. C. Daily rainfall disaggregation: an analysis for the Rio Grande do Sul state. Scientia Agraria, v. 16, n. 3, p. 1- 21, 2015. http://dx.doi.org/10.5380/rsa.v16i3.46320

CETESB. Drenagem urbana: manual de projetos. São Paulo: DAEE/CETESB, 1986.

COELHO FILHO, J. A. P.; MELO, D. C. R.; ARAÚJO, M.L.M. Estudo de chuvas intensas para a cidade de Goiânia/GO por meio da modelação de eventos máximos anuais pela aplicação das distribuições de Gumbel e Generalizada de Valores Extremos. Ambiência, v. 13, n. 1, p. 75-88, 2017. https://dx.doi.org/10.5935/ambiência.2017.01.05

DE AlCÂNTARA, L. R. P.; COUTINHO, A. P.; SANTOS NETO, S. M.; DE MELO, T. A. T.; COSTA; L. V.; RIBAS, L. V. S; ANTONINO, A. C. D; ALVES, E. M. Modelos probabilísticos para eventos de precipitações extremas na cidade de Palmares-PE. Revista Brasileira de Geografia Física, v. 12, n. 4, p. 1355-1369, 2019. https://dx.doi.org/10.26848/rbgf.v12.4.p1355-1369

DE MARIA, I. C.; DRUGOWICH, M. I.; BORTOLETTI, J. O.; VITTI, A. C.; ROSSETTO, R.; FONTES, J. L., TCATCHENCO, J., MARGATHO, S. F. Recomendações gerais para a conservação do solo na cultura da cana-de-açúcar. Campinas: IAC, 2016. 100 p. (Boletim Técnico IAC, 216).

DENG, S.; LI, M.; SUN, H.; CHEN, Y.; QU, L. ZHANG, X. Exploring temporal and spatial variability of precipitation of Weizhou Island, South China. Journal of Hydrology: Regional Studies, v. 9, p. 183-198, 2017. https://dx.doi.org/10.1016/j.ejrh.2016.12.079 
DIAS, E. C.; PENNER, G. C. Contabilização de equações de Intensidade-Duração-Frequência disponíveis no Brasil. Anuário do Instituto de Geociências, v. 42, n. 1, p. 209-216, 2019. http://dx.doi.org/10.11137/2019_1_209_216

GONÇALVES, L. J.; TAGLIAFERRE, C.; CASTRO FILHO, M. N; BRITO NETO, R. L.; SILVA, B. L; ROCHA, F. A. Determination of intensity-duration-frequency equations for sites in Bahia state. Irriga, v. 1, n. 1, p. 109-115, 2019. https://dx.doi.org/10.15809/irriga.2019v1n1p109-115

MARRA, F.; MORIN, E.; PELEG, N.; MEI, Y.; ANAGNOSTOU, E. N. Intensity-durationfrequency curves from remote sensing rainfall estimates: comparing satellite and weather radar over the eastern Mediterranean. Hydrolog. Earth Syst. Sci, v.21, p.2389-2404, 2017. https://dx.doi.org/10.5194/hess-21-2389-2017

MARTINS, D.; KRUK, N. S.; MAGNI, N. L. G.; QUEIROZ, P. I. B de. Comparação de duas metodologias de obtenção da equação de chuvas intensas para a cidade de Caraguatatuba (SP). Revista DAE, p. 34-49, 2017. https://dx.doi.org/10.4322/dae.2016.033

MIRZAEI, M.; HUANG, Y.; LEE, T. S.; EL-SHAFIE, A.; GHAZALI, A. H. Quantifying uncertainties associated with rainfall depth duration frequency curves. Natural HazardsSpringer, v. 71, n. 2, p. 1227-1239, 2014. https://dx.doi.org/10.1007/s11069-013-0819-3

MIRZAEI, M.; HUANG, Y. F.; EL-SHAFIE, A.; CHIMEH, T.; LEE, J.; VAIZADEH, N.; ADAMOWSKI, J. Uncertainty analysis for extreme flood events in a semi-arid region. Natural Hazards, v. 78, n. 3, p. 1947-1960, 2015. https://dx.doi.org/10.1007/s11069015-1812-9

MISTRY, P. B.; SURYANARAYANA, T. M. V. Estimation of Annual One Day Maximum Rainfall using Probability Distributions for Waghodia Taluka, Vadodara. Global Research and Development Journal for Engineering, p. 296-300, 2019.

NAGHETTINI, M.; PINTO, É. J. A. Hidrologia Estatística. Belo Horizonte: CPRM, 2007.

NAMITHA, M. R.; VINOTHKUMAR, V. Development of empirical models from rainfallintensity-durations-frequency y curves for consecutive Day maximum rainfall using GEC distribution. Journal of Pharmacognosy and Phytochemistry, v. 8, n. 1, p. 275-2709, 2019.

OLOFINTOYE, O. O.; SULE, B.F.; SALAMI, A.W. Best-fit probability model for peak daily rainfall of selected Cities in Nigeria. New York Science Journal, v. 2, n. 3, p. 1-12, 2009.

OTTERO, C. R.; CHARGEL, L. T.; HORA, M. A. G. M. Análise de frequência dos dados pluviométricos observados em 2011 a 2013 na região Serrana do Rio de Janeiro. Revista Brasileira de Meteorologia, São Paulo, v.33, n.1, p.131-139, 2018. https://dx.doi.org/10.1590/0102-7786331007

OUALI, D.; CANNON, A. J. Estimation of rainfall intensity-duration-frequency curves at ungauged locations using quantile regression methods. Stochastic Environmental Research and Risk Assessment, v. 32, p. 2821-2836, 2018. https://dx.doi.org/10.1007/s00477-018-1564-7.0123

PENNER, G. C.; LIMA, M. P. Comparação entre métodos de determinação da equação de chuvas intensas para a cidade de Ribeirão Preto. Geociências, v. 35, n. 4, p. 542-559, 2016. 
PETRUCCI, E.; OLIVEIRA, L. A. Relações entre intensidade, duração e frequência das precipitações máximas de 24 horas e equação de chuvas intensas para a cidade de Uberlândia-MG. Revista Brasileira de Climatologia, ano 15, v. 25, p. 337-354, 2019. https://dx.doi.org/10.5380/abclima.v25i0.57767

QUADROS, L. E.; QUEIROZ, M. M. F.; VILAS BOAS, M. A. Distribuição de frequência e temporal de chuvas intensas. Acta Scientiarum, v. 33, n. 3, p. 401-410, 2011. https://dx.doi.org/10.4025/actasciagron.v33i3.6021

RANGEL, E. M.; HARTWIG, M. P. Análise das curvas de intensidade-duração-frequência para a cidade de Pelotas através de uma função de desagregação. Revista Thema, v. 14, n. 2, p. 63-77, 2017. https://dx.doi.org/10.15536/thema.14.2017.63-77.353

SABINO, M.; SOUZA, A. P.; ULIANA, E. M.; LISBOA, L.; ALMEIDA, F. T.; ZOLIN, C. A. Intensity-duration-frequency of maximum rainfall in Mato Grosso State. Revista Ambiente \& Água, v. 15, n. 1, e2373, 2020. https://dx.doi.org/10.4136/ambi-agua.2373

SILVA, C. B.; OLIVEIRA, L. F. C. Relação Intensidade-Duração-Frequência de chuvas extremas na região Nordeste do Brasil. Revista Brasileira de Climatologia, ano 13, v. 20, p. 267-283, 2017. https://dx.doi.org/10.5380/abclima.v20i0.49286

SILVEIRA, A. L. L da. Equações cumulativas sequenciais do hietograma do método de Chicago. Revista Brasileira de Recursos hídricos, v. 21, n. 3, p. 646-651, 2016. https://dx.doi.org/10.1590/2318-0331.011615094

SOUZA, R. O. R. M.; SCARAMUSSA, P. H. M.; AMARAL, M. A. C. M.; NETO, J. A. P.; PANTOJA, A. V.; SADECK, L. W. R. Equações de chuvas intensas para o estado do Pará. Revista Brasileira de Engenharia Agrícola e Ambiental, v. 16, n. 9, p. 999-1005, 2012. https://dx.doi.org/10.1590/S1415-43662012000900011

TFWALA, C. M.; VAN RENSBURG, L. D.; SCHALL, R.; MOSIAM S. M.; DLAMINI, P. Precipitation intensity-duration-frequency curves and their uncertainties for Ghaap $\begin{array}{lllllll}\text { plateau. Climate Risk Management, v. } & \text { 16, } & \text { p. } & 1-9,17 .\end{array}$ https://dx.doi.org/doi.org/10.1016/j.crm.2017.04.004 


\begin{tabular}{|} 
Ambiente \& Água - An Interdisciplinary Journal of Applied Science \\
ISSN 1980-993X - doi:10.4136/1980-993X \\
www.ambi-agua.net \\
E-mail: ambi.agua@gmail.com
\end{tabular}

\title{
Performance of slow sand filters in the after-treatment of effluent from Pernambuco state textile center
}

\author{
ARTICLES doi:10.4136/ambi-agua.2586
}

Received: 23 May 2020; Accepted: 15 Sep. 2020

\begin{abstract}
Alanna Maria do Nascimento Bezerra1 ${ }^{1}$; Marcos Henrique Gomes Ribeiro ${ }^{2}{ }^{D}$; Artur Paiva Coutinho ${ }^{1}$; Ana Emília Carvalho de Gusmão da Cunha Rabelo ${ }^{3}$; Elizabeth Amaral Pastich Gonçalves ${ }^{1 *}$ (iD
\end{abstract}

\footnotetext{
${ }^{1}$ Centro Acadêmico do Agreste. Núcleo de Tecnologia. Universidade Federal de Pernambuco (UFPE), Avenida Marielle Franco, s/n, Km 59, CEP: 55014-900, Caruaru, PE, Brazil.

E-mail: alannamnb@gmail.com, artur.coutinho87@gmail.com

${ }^{2}$ Centro de Tecnologia e Geociências. Departamento de Engenharia Civil e Ambiental. Universidade Federal de Pernambuco (UFPE), Avenida da Arquitetura, s/n, CEP: 50740-550, Recife, PE, Brazil.

E-mail: mhgribeiro@gmail.com

${ }^{3}$ Centro de Tecnologia e Geociências. Departamento de Energia Nuclear. Universidade Federal de Pernambuco

(UFPE), Avenida Luiz Freire, n 1000, CEP: 50740-545, Recife, PE, Brazil. E-mail: anaerabelo@gmail.com

*Corresponding author. E-mail: bethpastich@yahoo.com.br
}

\begin{abstract}
Jean laundering generates significant effluent flows with a high organic load, color, and other pollutants, making it difficult to adjust effluent releases within legal limits. Slow Sand Filters (SSF) with downflow were tested for seven days (bench scale), to propose an aftertreatment of effluents from an Effluent Treatment Plant of a jean laundry. The research evaluated the removal of the following parameters: color, turbidity, chemical and biochemical oxygen demand, conductivity, ammonia, total phosphorus and salinity of the textile effluent. The experimental apparatus had four SSF: the first filter was fed with distilled water, while the other three filters (triplicates) were fed with effluent. The filters had, on average, the following removal efficiencies: $91 \%$ for ammonia, $61.24 \%$ color, $89.43 \%$ turbidity, and $83.54 \%$ for phosphorus. Regarding the removal of organic matter, $98.11 \%$ for BOD and $81.17 \%$ for COD, demonstrating that SSFs were efficient in removing particulate, dissolved materials and organic matter.
\end{abstract}

Keywords: BOD, color, dissolved oxygen, salinity, soil column.

\section{Desempenho de filtros lentos de areia no pós-tratamento de efluente do polo têxtil do estado de Pernambuco}

\section{RESUMO}

As lavanderias de Jeans geram grandes vazões de efluentes com elevada carga orgânica, cor e outros poluentes, o que dificulta sua adequação para lançamentos dentro dos limites legais. Filtros lentos de areia (FLA) com fluxo descendente foram testados durante 7 dias, em escala de bancada, a fim de propor um pós-tratamento de efluentes de uma Estação de Tratamento de Efluentes de lavanderia de jeans. Nesta pesquisa, foi avaliada a remoção dos seguintes parâmetros: cor, turbidez, demanda química e bioquímica de oxigênio, condutividade, amônia, 
fósforo total e salinidade. O experimento contou com quatro FLA: o primeiro alimentado com água destilada e os outros três alimentados com o efluente têxtil (triplicatas). Os FLA removeram $91 \%$ de amônia, $61,24 \%$ de cor, $89,43 \%$ de turbidez e $83,54 \%$ de fósforo. Quanto à remoção de matéria orgânica, em média houve remoção de $98,11 \%$ para $\mathrm{DBO}$ e $81,17 \%$ para DQO, demonstrando que os FLA foram eficientes na remoção de materiais particulados e dissolvidos.

Palavras-chave: coluna de solo, cor, DBO, oxigênio dissolvido, salinidade.

\section{INTRODUCTION}

The Brazilian semiarid is characterized as a region of low water availability (Rocha and Soares, 2015). Despite its negative water balance, the area has outstanding Local Productive Arrangements (LPA). The Pernambuco Agreste clothing center, known as "Mode LPA", is composed of Caruaru, Santa Cruz do Capibaribe, and Toritama, embracing the second largest textile center in Brazil, which is an essential sector for the region's development. However, according to Abreu et al. (2008), due to the water scarcity in the area and the lack of adequate effluent treatment systems, the implementation of the textile industry imposes a severe environmental and health risk for the surrounding community, mainly due to the mutagenic and carcinogenic nature of dyes and their intermediate byproducts (sludge and textile effluents).

Throughout the methods for textile processing, different constituents are generated, such as acids, bleaching chemicals, enzymes, starch, dyes, resins, solvents, waxes, oils, among others. (Verma et al., 2012). These constituents produce a final effluent with high COD, BOD, total dissolved solids, color, and heavy metals (Chandanshive et al., 2017). This can result in chronic nutrient accumulation leading to artificial eutrophication, promoting change in the water color and exposing aquatic life to toxic substances (Esteves and Meirelles-Pereira, 2011).

There are many alternatives for treating textile effluents, which are combined to achieve a satisfactory level of waste removal. There is the use of anaerobic-reactor type UASB conjunction with process Fenton (Santos et al., 2017), chemical coagulation followed by lamella settler for sedimentation and disinfection (Abdel-Fatah et al., 2015), submerged anaerobic membrane bioreactors (Baêta et al., 2016), use of live microalgae in suspension (Jimeno et al., 2017) and a solid state fermentation system (Chicatto et al., 2018) for waste water discoloration.

Soils have good retention capacity for textile contaminants, especially in the case of dyes (Alexandre et al., 2020; Alves et al., 2020), proving that simple techniques also produce satisfactory results. Therefore, slow sand filtration appears as a simple alternative for treating textile effluents. Slow sand filtration is characterized by a low filtration rate, resulting in a high water retention time, which implies the development of a microbial community (Dias, 2011). The biological community developed around the grains of the sand bed assists in the appropriate process of removing suspended organic and inorganic matter and pathogenic organisms (Coelho and Di Bernardo, 2012). According to Tonetti et al. (2012), the process of this type of technology is based on applying the effluent on the surface of the sand filter intermittently through a distribution pipe. When the infiltration of the liquid persists, its purification by physical, chemical and biological processes comes about (Ausland et al., 2002).

Investigations regarding the use of slow filters for the treatment of textile effluent are essential to evaluate pollutants' retention potential (Egea-Corbacho et al., 2019), and thereby reducing the environmental risks, treatment costs, and areas used for treatment plants. Due to their simplicity and lower operating costs, slow filters are currently an attractive solution, especially in rural areas and small communities in developing countries (Bendida et al., 2013). Among the advantages of slow filters over fast filters, a highlight is not requiring water 
coagulation and frequent washing of the filtration units which results in high production of waste. The sand taken from the top of the filter layer can be washed or disposed of as dirty sand (Grace et al., 2016).

In this context, this research evaluates the performance of slow sand filters in the treatment of textile effluents from Pernambuco's Textile Center. It also assesses its efficiency in the suitability of the textile effluent for release into the water body and for hydro-agricultural reuse.

\section{MATERIALS AND METHODS}

\subsection{Study area}

The study was conducted in the city of Caruaru, in Pernambuco State, Brazil. The municipality belongs to the Mesoregion of Pernambuco's Agreste and is in the Ipojuca Valley Microregion. Caruaru has a dry climate of local steppe, with little rainfall throughout the year, corresponding to about $551 \mathrm{~mm}$ per year (APAC, 2019).

According to the latest IBGE census (IBGE, 2010), Caruaru has a population of 314,912 inhabitants, which ranks the region as the fourth most populous city in Pernambuco and the most populous municipality in the interior of the state. It is currently the Agretes' capital, standing out as the most significant economic, medical, academic, cultural, and tourist center of the region. Among these industrial activities, clothing and textiles are those that are most relevant, being responsible for the development and expansion of the municipality's economy.

\subsection{Textile effluent collection site}

The treated effluent used in this study was directly collected from a medium-sized textile laundry located in the city of Caruaru. This laundry has a production system based on degreasing, dyeing, washing, spinning and drying, as do most laundries in the region. The laundry effluent treatment plant in question is composed of a physical-chemical treatment, comprising coagulation, flocculation and decantation steps. The collected textile effluent was transported in a polypropylene container, properly sealed with a lid, previously sterilized in the laboratory by autoclaving. The sample was transported to the Environmental Engineering Laboratory (Laboratório de Engenharia Ambiental - LEA) and subsequently stored about 20 min after collection in the laundry under refrigeration at $4^{\circ} \mathrm{C}$.

\subsection{Soil sample collection}

The soil sample used in the sand filter experiment was collected at an experimental site belonging to the Agreste Academic Center of the Federal University of Pernambuco, located in the city of Caruaru. At first, the site was cleaned so that undesirable materials such as roots and vegetation could be removed from the soil. To collect the sample, tools such as shovel, hoe, and pick were used, to obtain a portion equivalent to $20 \mathrm{~cm}$ of the soil layer to fill the sand filters.

After collecting the soil sample, a soil characterization test was performed to determine the physical indices of the sample.

For the determination of the soil bulk density, the criteria established in the Manual of Soil Analysis Methods (Claessen, 1997) was adopted. Particle size analysis was performed according to the requirements of NBR 7181 (ABNT, 1984). To determine the soil density, undisturbed samples were collected using the Uhland soil sampler.

From this soil sample, the grain fractions were also determined based on sieve and sedimentation analysis. This test aims to obtain the soil particle-size curve and identifies its granular dimensions.

\subsection{Assembly of slow sand filters}

Slow sand filters (SSF) were assembled on a cylindrical acrylic column (Figure 1). The cylinders have an inner and outer diameter of 6 and $7 \mathrm{~cm}$, respectively, with a height equivalent 
to $30 \mathrm{~cm}$. A transparent material composes the acrylic cylinders to facilitate the monitoring of the flow path of the used effluent sample.
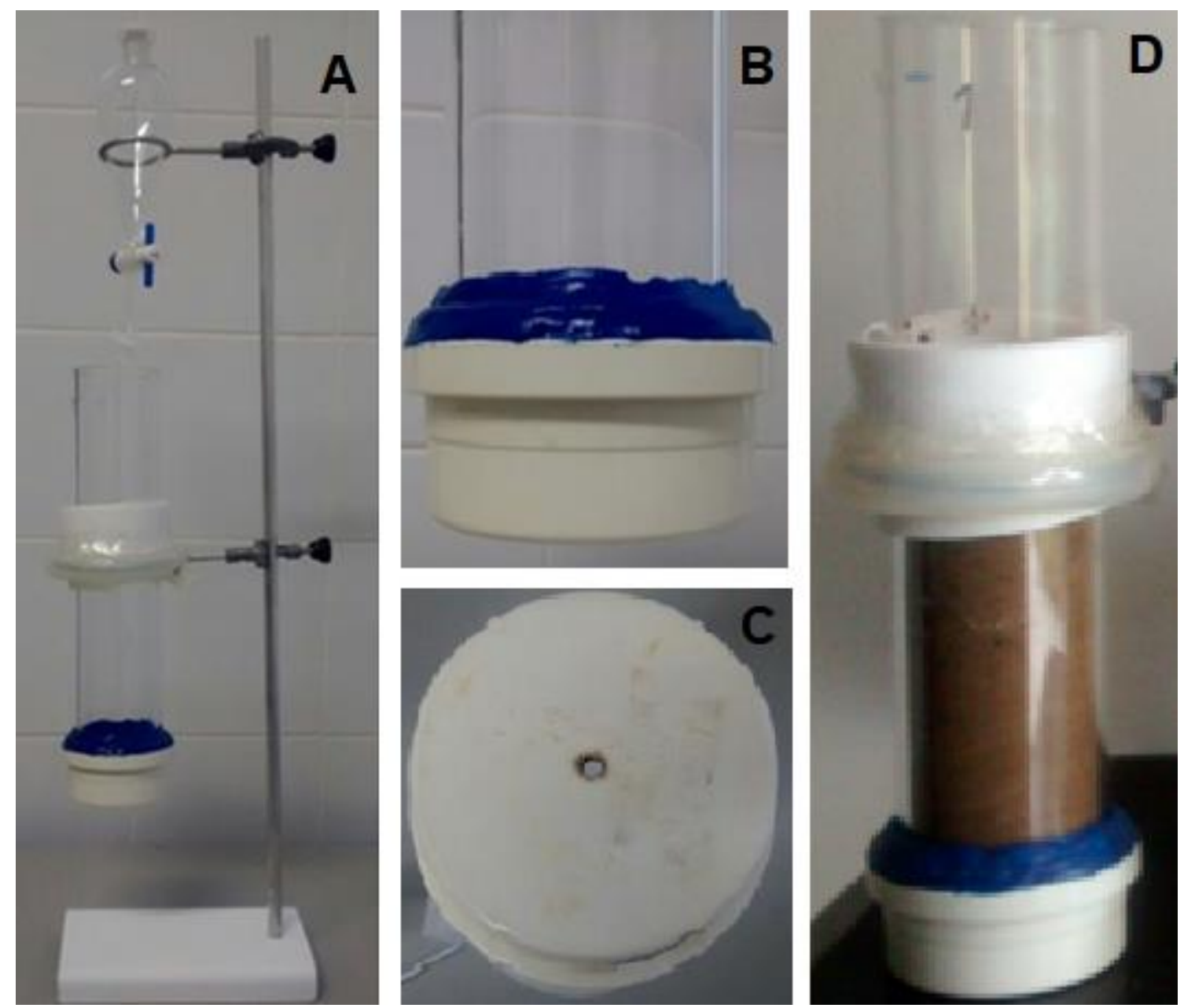

Figure 1. Assembly of a slow sand filter: a) Support model for the column and filter feeder; b) Sealing rubber and PVC cover for column sealing; c) Drilled hole for leachate passage; d) Filter filled with soil.

On the outside of the filters, to ensure better support of the tubes in the metal supports, rubberized material such as Satin Vinyl Foam (S.V. F.) adhered to the hose was used, and the two materials were fixed with hot glue. Thus, the slow sand filters could be supported on the metal rod and suspended (Figure 1a) so that the leachate could be collected at the tube`s bottom.

In the lower part of the filters, a $75 \mathrm{~mm}$ diameter pipe end-cap, generally used for a PVC sewage pipe, was used to seal the ground passage, and each cap was fixed at the bottom of each tube using rubber seal (Figure 1b). Finally, a hole was drilled in the center of each end cap (Figure 1c) to ensure the passage of leached samples through the filters.

A $20 \mathrm{~cm}$ single layer, consisting of the collected sand (Figure 1d) was used to finish the assembly of the sand filters. Therefore, the filters were filled to ensure the same density as in the field. To reach a density of $1.32 \mathrm{~g} \mathrm{~cm}^{-3}, 746.44 \mathrm{~g}$ of soil were required for each sand filter, because the filters needed to maintain a fixed height of $20 \mathrm{~cm}$, and the inner diameter of each tube was $6 \mathrm{~cm}$.

\subsection{Experimental procedure}

Four sand filters named SSF1, SSF2, SSF3, and SSF4 were used for this research. The first slow sand filter (SSF1) was fed with distilled water to serve as control to the experiment. The 
other three filters (SSF2, SSF3, and SSF4) were irrigated with the textile effluent collected in the laundry.

Slow sand filters are characterized by infiltration rates between 2 and $6 \mathrm{~m}^{3} \mathrm{~m}^{-2}$ day . Therefore, for the present study filters with an infiltration rate equal to $4.24 \mathrm{~m}^{3} \mathrm{~m}^{-2}$ day $^{-1}$ were used, which was measured by the time required for all the liquid to be leached through the filter and adjusted with the aid of the flow regulating funnel.

Regarding the leachate volume, it was established that the volume in each sand filter would comprise only $125 \mathrm{~mL}$ per day over seven days, as it is the time limit for the main characteristics of the textile effluent to be fully conserved and used during the leaching. Table 1 presents the parameters evaluated in the textile effluent (crude and leachate), the analysis frequency, and employed method, based on APHA et al. (2012).

Table 1. Parameters evaluated in textile effluent.

\begin{tabular}{ccc}
\hline Parameters & Employed Method & Frequency \\
\hline pH & conductivity & nephelometric \\
Turbidity & spectrophotometric \\
Color & conductivity & Daily, for seven days \\
Conductivity & multiparameter probe \\
Salinity & multiparameter probe \\
Temperature & membrane electrode \\
OD & manometric \\
BOD & colorimetric \\
COD & titrimetric & Once, on the last day of the experiment \\
Ammoniacal Nitrogen & colorimetric & \\
Phosphorus &
\end{tabular}

\section{RESULTS AND DISCUSSION}

Table 2 shows the percentages of sand, silt and clay, and the textural classification. According to these data, the soil is classified as sand with compact angular granulation and has an average apparent porosity of $55.97 \%$. The textural classification is of type Sandy Loam.

Table 2. Particle-size fraction of the soil used for the filters.

\begin{tabular}{lcc}
\hline \multicolumn{2}{l}{ Particle-size fraction } & Proportion (\%) \\
\hline Clay & - & 16.06 \\
\hline Silt & - & 22.88 \\
\hline \multirow{3}{*}{ Sand } & Very fine & 5.90 \\
& Fine & 16.12 \\
& Medium & 13.37 \\
& Coarse & 12.02 \\
& Very coarse & 9.19 \\
\hline
\end{tabular}

Figure 2 shows the particle-size curve observed in the sand (soil) sample. In Brazil, NBR 
13969 (ABNT, 1997) regulates sand filter size. According to this standard, the effective average diameter (D10), the non-uniformity coefficient (CNU) and the depth of the sand layer should be considered in the project. These criteria are also evaluated by the USEPA (1999) standard.

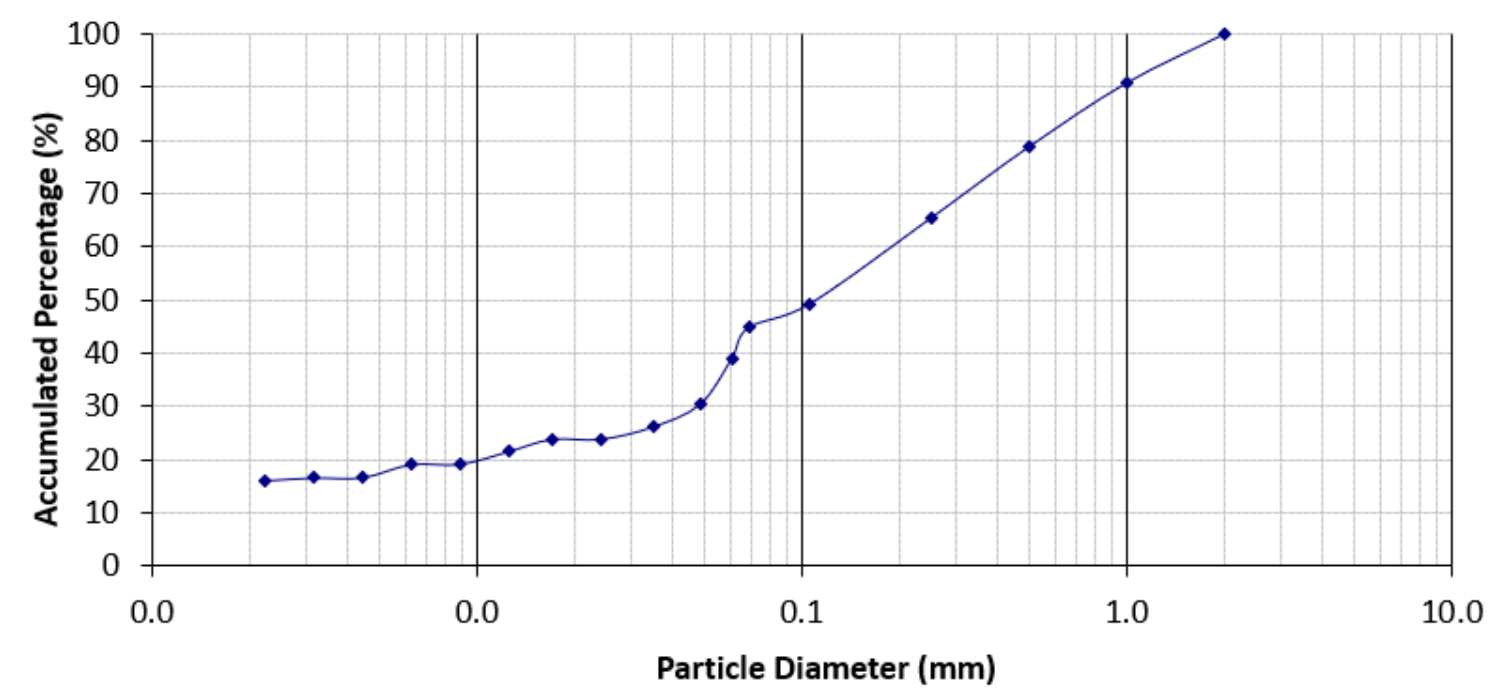

Figure 2. Particle-size distribution curve of the used sand.

The effective mean diameter (D10) affects the infiltration rate of the affluent in the riverbed and the penetration depth of the insoluble solid matter. The non-uniformity coefficient represents the inequality in particle size. The higher this parameter, the better graded is the sand. The characteristics of the filter media are summarized in Table 3 and compared to the previously mentioned current standards.

Table 3. Summary of filter characteristics and comparison with the cited standards.

\begin{tabular}{lccc}
\hline \multirow{2}{*}{ Parameters } & \multicolumn{3}{c}{ Consulted Normatives } \\
\cline { 2 - 4 } & SSF & NBR 13969:1997 & USEPA (1999) \\
\hline Sand Depth (m) & 0.20 & 0.70 & 0.45 to 0.91 \\
Soil type & Sandy loam & n.s & n.s \\
Effective average diameter (D10) $(\mathrm{mm})$ & 1.00 & 0.25 to 1.20 & 0.25 to 0.75 \\
Non-uniformity coefficient (CNU) & 0.062 & Lower than 4 & Lower than 4 \\
\hline
\end{tabular}

Note: n.s.= non specified.

The effective average diameter (D10) is equal to the diameter of the sieve that allows $10 \%$ of the soil to pass through. From Figure 2, it can be inferred that the passing percentage of $10 \%$ equals the cumulative percentage of $90 \%$, assigning a value equal to $1.00 \mathrm{~mm}$ for D10. The non-uniformity coefficient (NUC) is equivalent to the diameter of the sieves that allow $60 \%$ of the soil divided by D10 to pass. Similarly, $60 \%$ of the passing soil equals $40 \%$ of accumulated soil, this value being 0.062, as observed in Figure 2. Thus, the NUC is 0.062 . Therefore, these two parameters make the chosen soil suitable for use as a slow sand filter material.

Figure 3a shows the dynamics of the textile effluent's $\mathrm{pH}$ before and immediately after filtration and Figure $3 \mathrm{~b}$ shows the study of dissolved oxygen slow sand filters. 


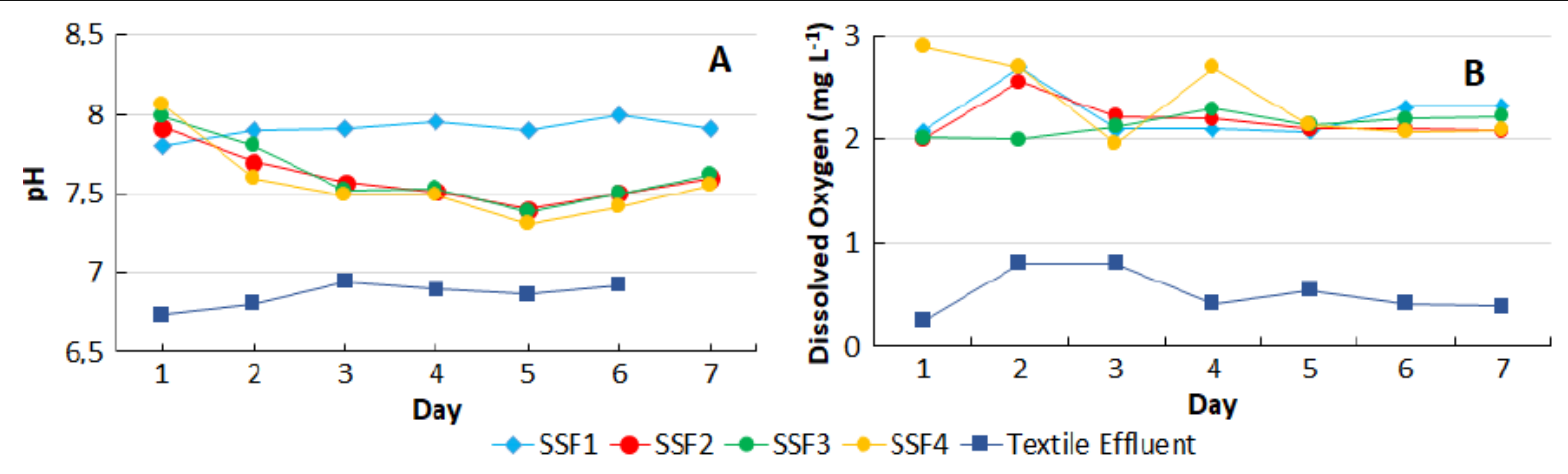

Figure 3. Graphs for daily analysis of $\mathrm{pH}$ and dissolved oxygen of textile effluents before and after filtration.

When the purpose of the effluent's treatment is to use it as agricultural reuse water, the $\mathrm{pH}$ becomes relevant once the soil texture and structure are known. The $\mathrm{pH}$ of water, along with the soil and plant species, determine nutrient uptake by the capillary root (Souza et al., 2010). The water used for irrigation must remain in the $\mathrm{pH}$ value range between 6.5 and 8.4. If wastewater presents values outside this range, it may cause nutritional imbalance to the plant (Sousa et al., 2005). From the results expressed in Figure 3a, it is observed that the $\mathrm{pH}$ values for the leachate of SSF2, SSF3, and SSF4 (irrigated with textile effluent) presented results within the allowed $\mathrm{pH}$ range. According to Armindo et al. (2015), changes in $\mathrm{pH}$ may cause the solidification of some elements that were previously dissolved. The already established $\mathrm{pH}$ value range must also be met to avoid problems with pipes and equipment used for irrigation.

Conversely, the $\mathrm{pH}$ of the collected samples, after going through SSF2, SSF3, and SSF4, presented an average value of 7.6. This result is close to the average value for SSF1, a filter filled with distilled water. Brazilian Resolution No 430 (Conama, 2011) recommends $\mathrm{pH}$ values for effluent discharge into receiving bodies between 5 and 9; in other words, the filtered samples reached the values allowed by the standard.

The dissolved oxygen (DO) concentration shown in Figure $3 \mathrm{~b}$ is directly linked to the presence of organic matter. Once in aerobic organic matter stabilization processes, the DO is consumed by bacteria, as well as by other chemical and biological processes that consume DO from the environment. In general, the higher the DO concentration in water sources, the better the water quality from the perspective of this parameter. According to Figure $3 \mathrm{~b}$, it is noticed that the textile effluent presented much lower dissolved oxygen concentrations than the samples that passed through the filtration. The low DO result for the effluent can be explained by the high level of COD and BOD.

The high concentrations of DO compared to the values expressed before passing through the filters demonstrate the high aeration capacity of slow, intermittent sand filters. Aeration can be explained by the time the filters rest between applications, as applications were performed every 24 hours. In this way, the air is allowed into the sand pores, positively meeting the metabolism of aerobic bacteria and allowing dilution of oxygen in the liquid mass.

The average DO value for filters that received the textile effluent was $2.23 \mathrm{mg} \mathrm{L}^{-1}$. Tonetti et al. (2012) showed that waters with these dissolved oxygen concentrations can be used for irrigation of vegetables, fruit and park plants, as well as aquaculture.

Figure 4a shows the turbidity before and after filtration and Figure $4 \mathrm{~b}$ shows the study of color. Turbidity, shown in Figure 4a, is caused by the presence of suspended particles in water. It is an essential property in localized irrigation because sedimented water can cause emitter clogging, altering the flow rate. This physical characteristic can be reduced through the filtration process. The results for the slow sand filters are much lower than the values for the textile effluent. 


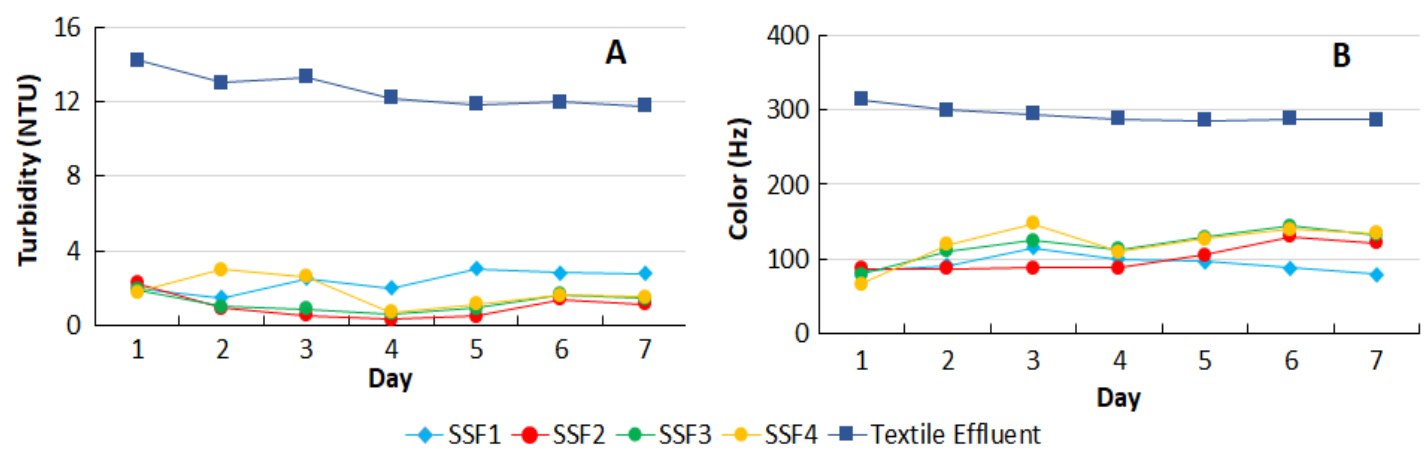

Figure 4. Graphs for daily analysis of turbidity and color of textile effluents before and after filtration.

The textile effluent, before application on the filters, presented an average turbidity of 12.61 NTU. The average turbidity for SSF2, SSF3, and SSF4 (leachate) filters was 1.3 NTU, which is considered an acceptable value for localized irrigation systems regarding clogging problems. Paterniani et al. (2008) conducted a study with slow filters to remove suspended solid particles in water samples. The study obtained turbidity values up to $16.9 \mathrm{NTU}$ and no clogging problems were detected in the drip irrigation system.

The color of a sample, shown in Figure 4b, indicates the presence of dissolved organic or inorganic matter and refers to the presence of suspended material, being a parameter that can be quickly and easily determined (Heller et al., 2007). Figure 4b shows the study of apparent color for slow sand filters. It was observed that the results for the slow sand filters irrigated with textile effluent (SSF2, SSF3, and SSF4) presented values close to the values of slow sand filters irrigated with distilled water (SSF1). That evidence shows that none of the filters had high leaching of the soil in the pipes.

It can be inferred that the color values for SSF2, SSF3, and SSF4 (leachate) were lower than the values presented in the raw textile effluent, with results close to those from SSF1. The efficiency of apparent color removal on the filters was, on average, 61.24\%. According to findings presented by Paterniani et al. (2011), the slow sand filter used in this study as a filter medium for treated domestic effluent, with a soil layer of $75 \mathrm{~cm}$, presented an efficiency of $26 \%$. Therefore, it could be used in fertigation practices.

Figure 5a shows the electric conductivity before and after filtration and Figure $5 \mathrm{~b}$ shows the study of salinity. Through graphical analysis (Figure 5a), it was observed that the electrical conductivity in Filter 1 (SSF1), which was fed with distilled water, remained lower than the effluent, which was already expected, and constant over the days. The conductivity of the used water increased to feed the filter with the leachate; this was due to the ions that were carried from the soil along with the sample because the distilled water used to irrigate the filter had a value below $3 \mu \mathrm{S} \mathrm{cm}^{-1}$.
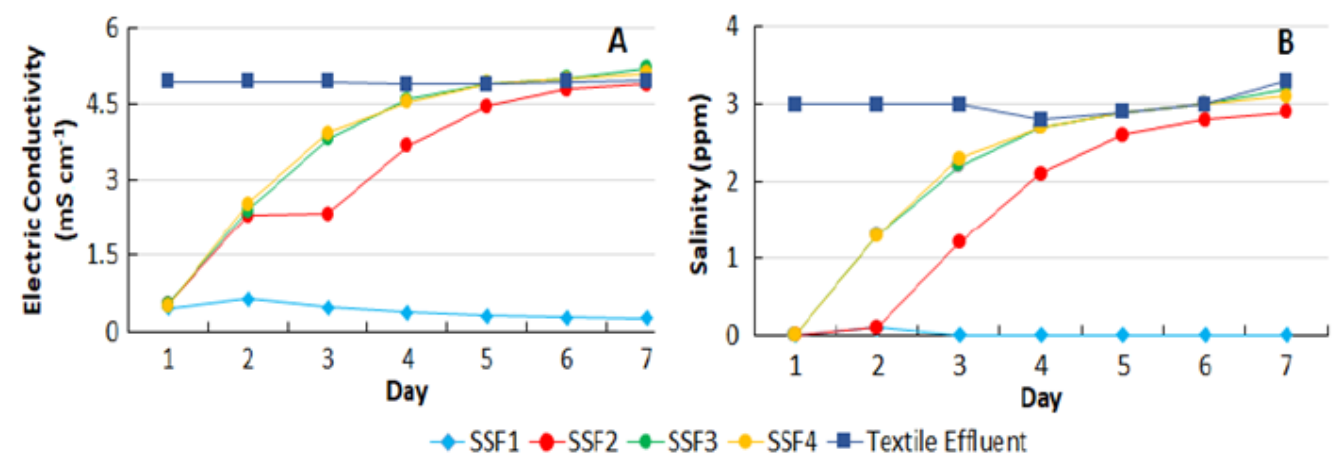

Figure 5. Graphs for daily analysis of electric conductivity and salinity of textile effluents before and after filtration. 
For SSF2, SSF3, and SSF4, it was observed that the electrical conductivity tended to reach the values of the used textile effluent, elucidating the fact that the soil reached possible saturation in relation to the ions, leaching the ions present in the effluent sample and reaching equilibrium. In general, the electrical conductivity of the SSF2, SSF3, and SSF4 filters presented an average value of $3610 \mu \mathrm{S} \mathrm{cm}^{-1}$. According to the data presented by Jeong et al. (2016), if the electrical conductivity of irrigation water is below $700 \mu \mathrm{S} \mathrm{cm}^{-1}$, crop growth will not be affected. However, if the electrical conductivity value is above $3000 \mu \mathrm{S} \mathrm{cm}^{-1}$, it can cause severe damage, characterizing the irrigation water as improper.

According to the primary and practical concepts established for water quality for irrigation purposes (Cordeiro, 2001), the average electrical conductivity value obtained in samples after passage through slow filters, characterized it as Class 4, i.e., very high salinity. However, if water is used for disposal in the soil, they must be permeable and have adequate drainage (Mancuso and Santos, 2003). Irrigation should be done in excess, providing considerable dissolution and the selected vegetation should be salt tolerant.

Salinity (Figure 5b) is a very limiting factor for irrigation as plant development and growth can be impaired. It was possible to observe that SSF1 showed practically no salinity record, demonstrating that the solvent (distilled water) and the soil used in the filters did not show salinity levels. The filters irrigated with the effluent presented behavior similar to the results expressed by the electrical conductivity. The salinity of SSF2, SSF3, and SSF4 increased during the experiment, converging with the effluent used.

The salinity values for the leachate from the irrigated filters with textile effluent do not meet the established standards for irrigation (Cordeiro, 2001). These results can be compared to the electrical conductivity values, which may leave the irrigated soil saline and infertile, impairing the development of plants. The more salts present in water, the higher the ability of water to conduct electric current. The presence of water-soluble salts can lead the soil to salinization conditions, harming plant growth. Thus, water with high concentrations of electrical conductivity should be avoided.

Another practice to reduce salinity problems is to apply an additional amount of water to leach out salts from irrigation. Nevertheless, the irrigation frequency and the application depth can be adjusted.

However, according to Armindo et al. (2015), it is possible to minimize the risk of salinity with sound soil and crop management. If the soil remains saline due to irrigation, crops that can grow satisfactorily under such conditions should be selected. Another practice to reduce salinity problems is to apply an additional amount of water to leach out salts from irrigation. Even so, the irrigation frequency and the application depth can be adjusted.

Table 4 shows the average BOD, COD, ammoniacal N, phosphorus, turbidity and color results for effluent samples before and after filtration. From the analysis of Table 4, it is noted that the textile effluent presented a BOD concentration of $440 \mathrm{mg} \mathrm{L}^{-1}$. This value when compared to the results of SSF2, SSF3, and SSF4 shows that the type of filter used in this experiment was able to significantly reduce BOD concentrations, with approximately $98 \%$ efficiency, adjusting the final effluent for the release. The removal of organic matter may have occurred by organic matter mineralization, degradation by aerobic microorganisms, and its accumulation in the soil. Resolution No. 430 (Conama, 2011) evidences that the permitted removal for release in watercourses should be $60 \%$, which is a sound result. SSF1, when irrigated with distilled water. The efficiency of turbidity removal averaged $89 \%$, which means a good performance.

Ammonia nitrogen and total phosphorus data are also presented in Table 4. The Table showed a high concentration of ammonia nitrogen and phosphorus for the textile effluent, which was already expected due to the chemicals used in industrial laundry processes. Table 4 also demonstrated that there was nutrient incorporation into the soil due to the low concentration of 
these parameters directly after the textile effluent passes through the slow sand filters. Ammonia nitrogen and phosphorus values presented in SSF1 are due to their concentrations in the soil, which were leached during the filtration process.

Table 4. Mean results of parameters for effluent samples before and after filtration.

\begin{tabular}{|c|c|c|c|c|c|c|}
\hline \multirow{2}{*}{ Parameter } & \multirow{2}{*}{ Values before the filters } & \multicolumn{4}{|c|}{ Values after the filters (leachate) } & \multirow{2}{*}{ Removal efficiency (\%) } \\
\hline & & SSF1 & SSF2 & SSF3 & SSF4 & \\
\hline $\mathrm{BOD}\left(\mathrm{mg} \mathrm{L}^{-1}\right)$ & 440 & 0 & 10 & 10 & 5 & $98.11 \pm 0.66$ \\
\hline $\mathrm{COD}\left(\mathrm{mg} \mathrm{L}^{-1}\right)$ & 756.01 & 78.39 & 124.33 & 165.45 & 136.34 & $81.21 \pm 2.80$ \\
\hline Ammoniacal $\mathrm{N}\left(\mathrm{mg} \mathrm{L}^{-1}\right)$ & 29.12 & 2.24 & 1.12 & 3.92 & 2.80 & $91.03 \pm 4.84$ \\
\hline Phosphorus (mg L $\mathrm{m}^{-1}$ ) & 3.69 & 1.74 & 0.61 & 0.80 & 0.42 & $83.54 \pm 5.12$ \\
\hline Turbidity (NTU) & 14.24 & 2.38 & 1.02 & 1.21 & 1.76 & $90.33 \pm 1.34$ \\
\hline Color $(\mathrm{Hz})$ & 314 & 80 & 122 & 133 & 135 & $58.60 \pm 2.23$ \\
\hline
\end{tabular}

According to Sousa et al. (2005), ammonia nitrogen values above $30 \mathrm{mg} \mathrm{L}^{-1}$ are not recommended for irrigation. For sensitive cultures, ammoniacal nitrogen concentrations above $5 \mathrm{mg} \mathrm{L}^{-1}$ result in negative effects. The filters were able to adjust the textile effluent for irrigation, reducing the initial concentration of $29.12 \mathrm{mg} \mathrm{L}^{-1}$ to values below $2 \mathrm{mg} \mathrm{L}^{-1}$.

Resolution $\mathrm{N}^{\mathrm{o}} 430$ (Conama, 2011) indicates that the maximum value for ammonia nitrogen for effluents discharged into receiving bodies should be a maximum of $20 \mathrm{mg} \mathrm{L}^{-1}$. The ammonia nitrogen values indicate that the filters were able to adapt the treated effluent for release into water bodies.

Figure 6 shows the final balance of the COD, ammonia nitrogen, and total phosphorus parameters. The COD (Figure 6a) of SSF2, SSF3 and SSF4, compared to that of the textile effluent used to feed the filters, proves that the incorporation of organic matter in the soil was approximately $81.17 \%$. According to Paterniani et al. (2011), these values are considered acceptable if the reuse purpose is fertigation of cooked, consumed plants, fertigation of inedible plants and reuse for environmental improvement.

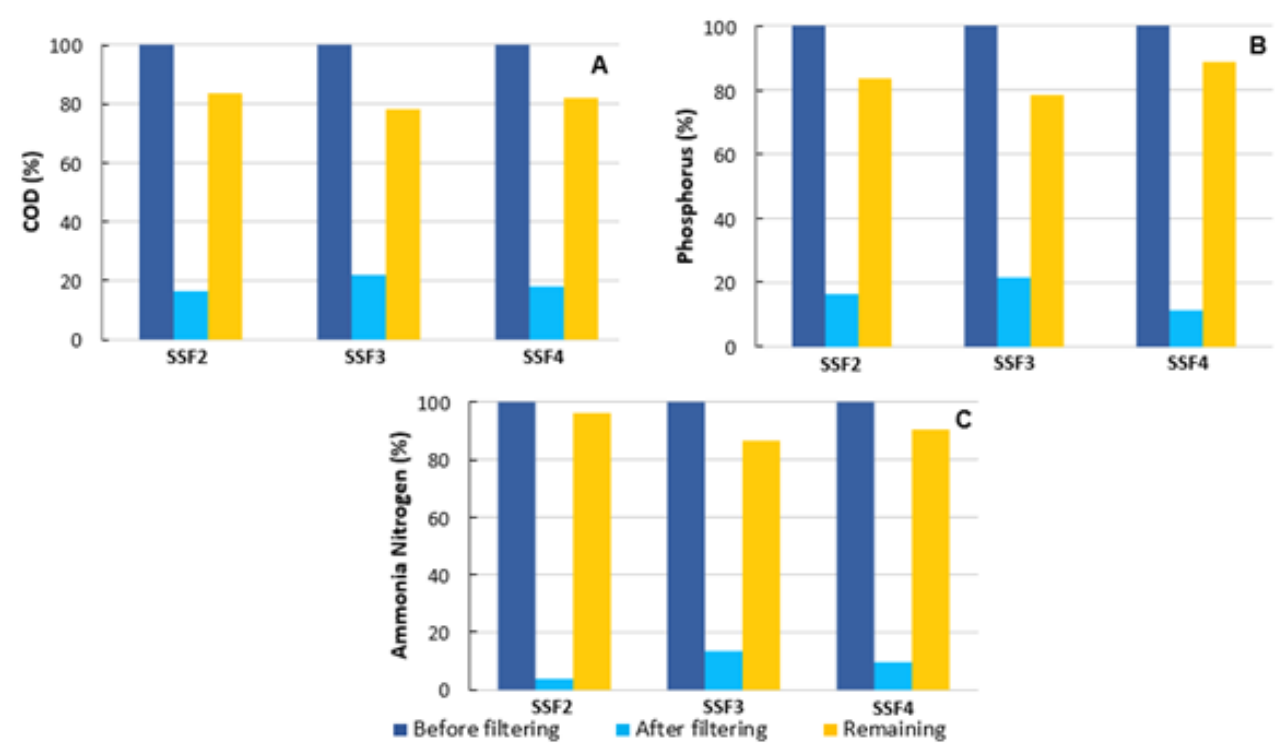

Figure 6. Graphs for the analyses performed at the end of the experiment.

According to the results expressed in Figure 6b, the phosphorus removal by slow sand filters was, on average, $83.54 \%$. Probably, this reduction was due to the microbiological 
assimilation of some bacteria genders, contributing efficiently to reduce the phosphorus concentration in the wastewater. This phosphorus release is vital for agricultural reuse, as this component is essential for storing and transporting energy to the plant. That is, without its presence, no metabolic process occurs (Sousa et al., 2005).

The average ammonia nitrogen removal among filters receiving textile effluent irrigation was $91 \%$ (Figure 6c), approximately. The removal obtained by Brito-Pelegrini (2006) was 12\% for landfill leachate (slurry). The low percentage of removal obtained by this author is explained by the fact that the effluent used in his work consists of landfill percolate, a highly toxic compound with a high recalcitrant organic load.

Table 5 shows the presence of nitrogen in the soil in the form of nitrate $\left(\mathrm{NO}_{3}{ }^{-}\right)$and ammonium $\left(\mathrm{NH}_{4}{ }^{+}\right)$ions in the natural soil sample and each column sample after irrigation with effluent. As expected, for filters irrigated with effluent, ion concentrations increased substantially. In the SSF1 soil, it was noted that the ammonium concentration regarding the raw soil was the same as it was irrigated with distilled water. However, the nitrate ion was leached, because the concentration in the soil was reduced.

In SSF2, SSF3, and SSF4 soils, which were irrigated with effluent, the values of the analyzed ions increased when compared to the raw soil values, with the values of ammonium higher than those of nitrate.

Table 5. Ammonium and nitrate in natural soil and soils after use as a filter.

\begin{tabular}{cccccc}
\hline Parameter & Rough soil & SSF1 & SSF2 & SSF3 & SSF4 \\
\hline Nitrate $\left(\mathrm{mg} \mathrm{kg}^{-1}\right)$ & 16.29 & 9.30 & 56.00 & 70.00 & 81.67 \\
Ammonium $\left(\mathrm{mg} \mathrm{kg}^{-1}\right)$ & 7.10 & 7.00 & 123.67 & 147.00 & 116.67 \\
\hline
\end{tabular}

Although ammonium was converted to nitrate by nitrification, the bacteria responsible for this biological process were unable to perform this conversion clearly. The reduction in microbial biomass may be relevant to nutrients supply such as sodium, indirectly compromising the nutritional disorder (Andrade et al., 2016).

\section{CONCLUSIONS}

The $\mathrm{pH}$ result for samples collected after filtration were within the recommended value range for agricultural reuse water, making the samples that passed the filters more fundamental than the textile effluent used.

Regarding the dissolved oxygen concentration, the filters were able to aerate between the rest period of each slow filter and were able to be used for irrigation.

The average color and turbidity reduction shows that the filters were efficient in removing particulates, dissolved materials, and organic matter, promoting the use of reused water in fertigation practices, performed through drip systems, which did not present clogging problems.

The electrical conductivity values and the salinity concentrations did not reach the allowable range for irrigation, necessitating the use of specific soil types and selected crops if irrigation is made with reused water from the slow sand filters. The high concentration of salts present in the textile effluent can be explained by the fact that the laundry chosen for this research uses salt in its textile production processes to fix color on garments.

Regarding organic matter removal, it was possible to conclude that the slow sand filters presented excellent efficiency concerning the organic matter incorporation in the used soil.

Regarding nutrient concentrations, the filters allowed the incorporation of nutrients in the used soil. Therefore, there was a high removal of these nutrients, evidencing a possible reduction of eutrophication in case of release in any outfall. However, the values obtained for these two nutrients after filtration still classify the reuse waters as suitable for irrigation 
according to international laws.

It is concluded that the simplified effluent post-treatment system of the textile industry, performed by slow sand filters with a $20 \mathrm{~cm}$ thick sand layer, was efficient, presenting no severe problems during its operation.

\section{ACKNOWLEDGMENTS}

This work was carried out with the support of the project "Transfer of Water and Mixtures of Reactive Pollutants in Anthropized Soils" (CNPq process No. 436875/2018-7) and of the Foundation for the Support of Science and Technology of the State of Pernambuco (FACEPE/CAPES process IBPG-0800-3.01/18).

\section{REFERENCES}

ABDEL-FATAH, M. A.; SHERIF, H. O.; AGOUR, F.; HAWASH, S. I. Textile waste water treatment by chemical coagulation technology. Global Journal of Advanced Engineering Technologies and Sciences, v. 2, n. 12, p. 20-28, 2015.

ABNT. NBR 13969: Tanques Sépticos - Unidades de tratamento complementar e disposição final dos efluentes líquidos - Projeto, construção e operação. Rio de Janeiro, 1997. 60 p.

ABNT. NBR 7181: solo - análise granulométrica. Rio de Janeiro, 1984. 13 p.

ABREU, M. C. S.; SILVA FILHO, J. C. L.; OLIVEIRA, B. C.; HOLANDA JÚNIOR, F. L. Perfis estratégicos de conduta social e ambiental: estudos na indústria têxtil nordestina. Gestão da Produção, v. 15, n. 1, p. 159-172, 2008. http://dx.doi.org/10.1590/S0104530X2008000100014

ALEXANDRE, J. I. S.; NETO, S. M. S.; COUTINHO, A. P.; MELO, T. A. T.; GONÇALVES, E. A. P.; GONDIM, M. V. S.; ANTONINO, A. C. D.; RABELO, A. E. C. G. C.; OLIVEIRA, A. L. Sorption of the Direct Black 22 dye in alluvial soil. Revista Ambiente \& Água, v. 15, n. 4, p. 1-13, 2020. http://dx.doi.org/10.4136/ambi-agua.2483

ALVES, A. T. A.; SILVA, L. T. M. S.; ALCÂNTARA, L. R. P.; BARROS, V. H. O.; NETO, S. M. S.; LIMA, V. F.; LIMA, J. R. S.; COUTINHO, A. P. ANTONINO, A. C. D. Sorption of Remazol Black B dye in alluvial soils of the Capibaribe River Basin, Pernambuco, Brazil. Revista Ambiente \& Água, v. 15, n. 2, p. 1-12, 2020. http://dx.doi.org/10.4136/ambi-agua.2491

ANDRADE, L. C.; ANDREAZZA, R.; CAMARGO, F. A. O. Atividade microbiana em solos sob doses de lodo de estação de tratamento de efluentes de um aterro industrial. Ciência Rural, v. 46, n. 2, p. 267-272, 2016. http://dx.doi.org/10.1590/0103-8478cr20140871

APAC. Monitoramento das Chuvas no Estado de Pernambuco. 2019. Available in: http://www.apac.pe.gov.br/meteorologia/chuvas-rmr.php. Access: Sep. 2019.

APHA; AWWA; WEF. Standard Methods for the examination of water and wastewater. 22nd ed. Washington, 2012. 1496 p.

ARMINDO, R. A.; FREITAS, K. S.; SOBENKO, L. R.; LASKOSKI, M.; ARAÚJO, T. F. Qualidade da água, métodos e manejo de irrigação para olericultura. Curitiba: SENAR, 2015. 78 p. 
AUSLAND, G.; STEVIK, T. K.; HANSSEN, J.F.; KOHLER, J.C.; JENSSEN, P.D. Intermittent filtration of wastewater - removal of fecal coliforms. Water Research, v. 36, n. 14, p. 3507-3516, 2002. http://dx.doi.org/10.1016/S0043-1354(02)00060-X

BAÊTA, B. E. L.; LIMA, D. R. S.; SILVA, S. Q.; AQUINO, S. F. Influence of the applied organic load (OLR) on textile wastewater treatment using submerged anaerobic membrane bioreactors (SAMBR) in the presence of redox mediator and powdered activated carbon (PAC). Brazilian Journal of Chemical Engineering, v. 33, n. 4, p. 817 825, 2016. http://dx.doi.org/10.1590/0104-6632.20160334s20150031

BENDIDA, A.; TIDJANI, A. E. B.; BADRI, A.; KENDOUCI, M. A.; NABOU, M. Treatment of domestic wastewater from the town of Bechar by a sand filter (sand of Beni Abbes Bechar Algeria). Energy Procedia, v. 36, p. 825-833, 2013. http://dx.doi.org/10.1016/j.egypro.2013.07.095

BRITO-PELEGRINI, N. N. Sistema de Filtração Lenta no Tratamento de Percolado do Aterro Sanitário de Limeira - SP, 2006, 101f. Dissertação (Mestrado em Engenharia Agrícola; Água e Solo) - Faculdade de Engenharia Agrícola, Universidade Estadual de Campinas, Campinas, 2006.

CHANDANSHIVE, V. V.; RANE, N. R.; TAMBOLI, A. S.; GHOLAVE, A. R.; KHANDARE, R. V.; GOVINDWAR, S. P. Co-plantation of aquatic macrophytes Typha angustifolia and Paspalum scrobiculatum for effective treatment of textile industry effluent. Journal $\begin{array}{lllllll}\text { of Hazardous } & \text { Materials, } & \text { v. 338, } & \text { p. 47-56, }\end{array}$ http://dx.doi.org/10.1016/j.jhazmat.2017.05.021

CHICATTO, J. A.; RAINERT, K. T.; GONÇALVES, M. J.; HELM, C. V.; ALTMAJER-VAZ, D.; TAVARES, L. B. B. Decolorization of textile industry wastewater in solid state fermentation with Peach-Palm (Bactris gasipaes) residue. Brazilian Journal of Biology, v. 78, n. 4, p. 718-727, 2018. http://dx.doi.org/10.1590/1519-6984.175074

CLAESSEN, M. E. C. Manual de métodos de análise de solo. Rio de Janeiro: EMBRAPACNPS, 1997. $212 \mathrm{p}$.

COELHO, E. R. C.; DI BERNARDO, L. Remoção de atrazina e metabólitos pela filtração lenta com leito de areia e carvão ativado granular. Engenharia Sanitária e Ambiental, v. 17, n. 3, p. 269-276, 2012. http://dx.doi.org/10.1590/S1413-41522012000300003

CONAMA (Brasil). Resolução n ${ }^{\circ} 430$ de 13 de maio 2011. Dispõe sobre as condições e padrões de lançamento de efluentes, complementa e altera a Resolução no 357, de 17 de março de 2005, do Conselho Nacional do Meio Ambiente-CONAMA. Diário Oficial [da] União: seção 1, Brasília, DF, n. 92, p. 89, 16 maio 2011.

CORDEIRO, G. G. Qualidade de Água para Fins de Irrigação: conceitos básicos e práticos. Petrolina: Embrapa Semiárido, 2001. 31 p.

DIAS, I. N. MBBR acoplado a filtro lento de areia e a osmose inversa para tratamento de efluente da indústria de petróleo visando reuso. 2011. 153f. Dissertação (Mestrado em Engenharia Química) - Instituto Alberto Luiz Coimbra, Rio de Janeiro, 2011.

EGEA-CORBACHO, A.; GUTIÉRREZ, S.; QUIROGA, J. M Removal of emerging contaminants from wastewater through pilot plants using intermitente sand/coke filters for its subsequent reuse. Science of the Total Environment, v. 646, p. 1232-1240, 2019. http://dx.doi.org/10.1016/j.scitotenv.2018.07.399 
ESTEVES, F. A.; MEIRELLES-PEREIRA, F. Fundamentos de limnología. Rio de Janeiro: Interciência, 2011. 826 p.

GRACE, M. A.; HEALY, M. G.; CLIFFORD, E. Performance and surface clogging in intermittently loaded and slow sand filters containing novel media. Journal of

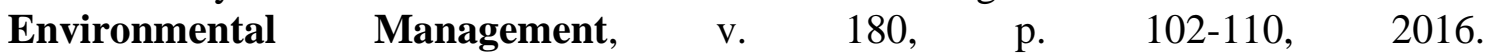
http://dx.doi.org/10.1016/j.jenvman.2016.05.018

HELLER, L.; VIEIRA, M. B.C. M.; BRITO, L. L. A.; SALVADOR, D. P. Association between the concentration of protozoa and surrogates in effluents of the slow sand filtration for water treatment. Brazilian Journal of Microbiology, v. 38, n. 2, p. 337-345, 2007. http://dx.doi.org/10.1590/S1517-83822007000200029

IBGE. Brasil/Pernambuco/Caruaru. IBGE, 2010. Available in: https://cidades.ibge.gov.br/brasil/pe/caruaru/pesquisa/23/25207?tipo=ranking\&ano=201 0\&indicador=25207. Access: April 2018.

JEONG, H.; KIM, H.; JANG, T. Irrigation water quality standards for indirect wastewater reuse in agriculture: a contribution toward sustainable wastewater reuse in South Korea. Water, v. 8, n. 4, p. 1-18, 2016. http://dx.doi.org/10.3390/w8040169

JIMENO, V. A. V.; MERCADO, E. R. A.; BALLESTEROS, D. M. P.; YÉPEZ, J. G. T.; VEJA, M. E. P. Uso de la microalga Chlorella sp. Viva em suspensión em la decoloración del agua residual de uma empresa textil. Prospect, v. 15, n. 1, p. 93-99, 2017. http://dx.doi.org/10.15665/rp.v15i1.829

MANCUSO, P. C. S.; SANTOS, H. F. Reuso de água. São Paulo: Manole, 2003. 590 p.

PATERnIANI, J. E. S.; SILVA, M. J. M.; RIBEIRO, T. A. P.; AIROLDI, R. P. S. A importância da qualidade da água nos projetos de irrigação - um estudo de caso. Revista Brasileira de Engenharia de Biossistemas, v. 2, n. 3, p. 223-230, 2008. http://dx.doi.org/10.18011/bioeng 2008v2n3 p 223-230

PATERNIANI, J. E. S.; SILVA, M. J. M.; RIBEIRO, T. A. P.; BARBOSA, M. Pré-filtração em pedregulho e filtração lenta com areia, manta não tecida e carvão ativado para polimento de efluentes domésticos tratados em leitos cultivados. Engenharia Agrícola, v. 31, n. 4, p. 803-812, 2011. http://dx.doi.org/10.1590/S0100-69162011000400018

ROCHA, R.; SOARES, R. R. Water scarcity and birth outcomes in the Brazilian semiarid.

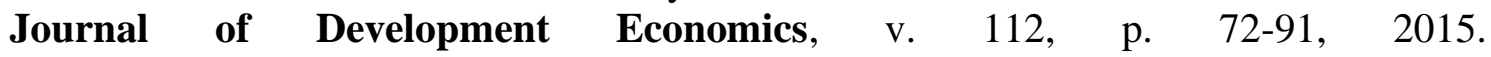
http://dx.doi.org/10.1016/j.jdeveco.2014.10.003

SANTOS, E. M. A.; NASCIMENTO, A. T. P.; PAUlinO, T. R. S.; BARROSO, B. C. S.; AGUIAR, C. R. Reator anaeróbio tipo UASB conjugado com processo Fenton para remoção de cor e demanda química de oxigênio de água residuária sintética de indústria têxtil. Engenharia Sanitária e Ambiental, v. 22, n. 2, p. 285-292, 2017. http://dx.doi.org/10.1590/S1413-41522016148154

SOUSA, J. T.; VAN HAANDEL, A. C.; CAVALCANTI, P. F. F.; FIGUEIREDO, A. M. F.. Tratamento de esgoto para uso na agricultura do semi-árido nordestino. Engenharia Sanitária e Ambiental, v. 10, n. 3, p. 260-265, 2005. http://dx.doi.org/10.1590/S141341522005000300011 
SOUZA, L. H.; NOVAIS, R. F.; ALVAREZ, V. H.; VILLANI, E. M. A. Efeito do pH do solo rizosférico e não rizosférico de plantas de soja inoculadas com Bradyrhizobium japonicum na absorção de boro, cobre, ferro, manganês e zinco. Revista Brasileira de Ciência do Solo, v. 34, n. 5, p. 1641-1652, 2010. http://dx.doi.org/10.1590/S010006832010000500017

TONETTI, A. L.; FILHO, B. C.; NICOLAU, C. E.; BARBOSA, M.; TONON, D. Tratamento de esgoto e produção de água de reuso com o emprego de filtros de areia. Engenharia Sanitária e Ambiental, v. 17, n. 3, p. 287-294, 2012. http://dx.doi.org/10.1590/S141341522012000300005

USEPA. Wastewater Technology Fact Sheet Intermittent Sand Filters. Washington, D.C., 1999. Available in: https://www3.epa.gov/npdes/pubs/isf.pdf. Access: Aug. 2019.

VERMA, A. K.; DASH, R. R.; BHUNIA, P. A review on chemical coagulation/flocculation technologies for removal of colour from textile wastewaters. Journal of Environmental $\begin{array}{lllllll}\text { Management, } & \text { v. } & 93, & \text { n. } & 1, & \text { p. } & 154-168,\end{array}$ http://dx.doi.org/10.1016/j.jenvman.2011.09.012 


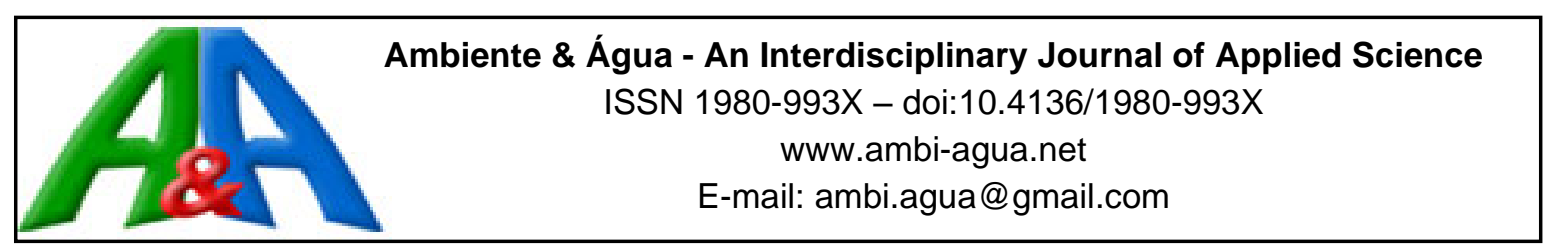

\title{
Ozonation as a pre-treatment of landfill leachate
}

\author{
ARTICLES doi:10.4136/ambi-agua.2592
}

Received: 08 Jun. 2020; Accepted: 15 Sep. 2020

\section{Leticia Tamara Hoffmann ${ }^{(D)}$ Matheus Caneles Batista Jorge* ${ }^{*}$; Adriana Garcia do Amaral ${ }^{\infty}$; Milene Carvalho Bongiovani ${ }^{\circledR}$; Roselene Maria Schneider}

\begin{abstract}
Instituto de Ciências Agrárias e Ambientais. Universidade Federal de Mato Grosso (UFMT), Avenida Alexandre Ferronato, n 1200, CEP: 78557-267, Sinop, MT, Brazil. E-mail: 1thhoffmann@gmail.com, adrianagamaral@gmail.com, milene.bongiovani@gmail.com,roselenems@yahoo.com.br

*Corresponding author. E-mail: jorge.batista2@ hotmail.com
\end{abstract}

\begin{abstract}
Ozone is an oxidizing agent with a potential for removing complex molecules, including those of difficult microbiological decomposition, such as the molecules found in landfill leachates. This effluent presents high organic content, including recalcitrant molecules. Therefore, this study evaluated the efficiency of ozonation in the treatment of raw leachate at the Primavera landfill, located in Mato Grosso, Brazil. The experiments were carried out using the batch system. The leachate $\mathrm{pH}$ value was set at 7 and 10, and the contact times between the gas and the leachate were 20,40,60, 80, and 100 minutes. Throughout the study, we analyzed color, turbidity, $\mathrm{pH}$ value, chemical oxygen demand (COD), and ultraviolet absorbance at 254 $\mathrm{nm}$ (UV abs) of the leachate, both before and after ozonation. Results show that ozonation presented high removal of color, $\mathrm{COD}$ and $\mathrm{UV}$ abs when $\mathrm{pH}$ was 7 . In contrast, turbidity removal was higher when the $\mathrm{pH}$ value was 10 . Regarding contact time, we observed a high removal of color (between $80 \%$ and $90 \%$ ) and UV abs (between $60 \%$ and $70 \%$ ) at 40 minutes, depending on the $\mathrm{pH}$ value. Removal was also high for turbidity (approximately $75 \%$ ) starting at 20 minutes with the $\mathrm{pH}$ value at 10 , and at 70 minutes with $\mathrm{pH}$ at 7 . The removal relation within all analyzed parameters (due to ozone consumption) decreased throughout the reaction time. Thus, we concluded that ozonation as a pre-treatment of leachate is indeed satisfactory because of its great capacity for organic material removal.
\end{abstract}

Keywords: degradation, leachate, ozone.

\section{Ozonização como pré-tratamento de lixiviado de aterro sanitário}

\section{RESUMO}

O ozônio é um agente oxidante com potencial para remoção de moléculas complexas, de difícil decomposição microbiológica, como as moléculas presentes em lixiviados. Este efluente apresenta alta carga orgânica, sendo parte desta recalcitrante. Assim, neste trabalho avaliou-se a eficiência da ozonização no tratamento do lixiviado bruto do aterro sanitário de Primavera, localizado no município de Sorriso - MT. Os experimentos foram realizados em batelada, com o valor de $\mathrm{pH}$ do lixiviado ajustado em 7 e 10, e tempos de contato entre o gás e o lixiviado iguais a 20, 40, 60, 80 e $100 \mathrm{~min}$. Foram analisados cor, turbidez, pH, DQO e absorbância ultravioleta a $254 \mathrm{~nm}$ (abs UV) do efluente antes e após a ozonização. Os resultados indicaram 
que a ozonização apresentou maiores remoções de cor, DQO e abs UV em pH 7, ao passo que a remoção de turbidez foi maior em pH 10. Em relação ao tempo de contato, foram observadas altas remoções de cor (entre 80 e $90 \%$ ) e abs UV (entre 60 e $70 \%$ ) em 40 minutos, dependendo do valor de $\mathrm{pH}$; e turbidez (aproximadamente 75\%) a partir do tempo 20 minutos, em valor de pH 10, e em 70 minutos, em pH 7. A relação de remoção entre todos os parâmetros analisados em função do consumo de ozônio foi decrescente ao longo do tempo de reação. Por fim, conclui-se que o emprego da ozonização como pré-tratamento de lixiviado é satisfatório, pois apresenta boa remoção de material orgânico.

Palavras-chave: chorume, degradação, ozônio.

\section{INTRODUCTION}

Population growth results in a disorderly growth of cities, mainly in large urban areas, which causes serious problems, especially in regard to the generation of urban waste and its final destination. Concern for residue disposal is studied both in a national (Agostinho et al., 2013) and an international scale (Lombardi et al., 2017), due to the awareness surrounding environmental protection.

The main worry regarding the release of residues is the liquids produced by the landfill, commonly known as leachate. Landfill leachate has high concentrations of organic matter, chlorides, ammoniacal nitrogen, as well as organic compounds of difficult degradation, such as humic substances and metals, depending on the properties of the residues disposed of in the landfill (Renou et al., 2008; Kawahigashi et al., 2014). If discarded inadequately, leachate can cause serious environmental harm.

When one considers efficient techniques for the decomposition of complex compounds, the ozonation technique stands out, either alone or associated with other processes (advanced oxidation processes/AOPs). Thus, it was the technique of choice in this study, and it appears to yield great results in the degradation of recalcitrant molecules (Araújo et al., 2016), as well as in the oxidation and mineralization of organic and inorganic species (Dezotti, 2008). The mentioned technique also showed high efficiency in the reduction of biochemical and chemical oxygen demands (BOD and COD, respectively) (Carvalho et al., 2018; Gomes and Schoenell, 2018; Brito and Silva, 2012) and turbidity (Mondardo et al., 2006).

The treatment process of landfill leachates through ozonation takes place by exposing the effluent to ozone gas. This gas is commonly generated by the Corona effect, which consists of passing atmospheric air between two electrodes. These two electrodes, due to their potential difference, will generate an electric discharge that breaks down the $\mathrm{O}_{2}$, resulting in the formation of atomic oxygen, which will bond to another $\mathrm{O}_{2}$ molecule and form ozone (Balakrishnan et al., 2002; Kunz et al., 1999; Almeida et al., 2004).

Ozone reacts with various organic compounds, chiefly amines and aromatic compounds rich in electrons, such as phenols and alkoxylated benzenes, which results in $\cdot \mathrm{OH}$ in parallel reactions. Therefore, $\bullet \mathrm{OH}$ is always formed when potable water and residual water are treated with ozone (von Sonntag and von Gunten, 2012).

Thereby, the key of the ozone treatment is based on the $\mathrm{O}_{3}$ direct reaction or on its indirect form, by generating the $\mathrm{OH}$ radical. Ozone, due to its elevated standard reduction potential $\left(\mathrm{E}^{0}\right.$ $=2.08 \mathrm{~V}$ ) reacts slowly and has high selectivity in regards to a great number of organic compounds (Almeida et al., 2004; Geppert, 2018). However, OH radicals also present a high standard reduction potential $\left(\mathrm{E}^{0}=2.80 \mathrm{~V}\right)$ and react quickly and without a selection for the majority of the compounds in an aqueous solution (Metcalf and Eddy, 2015; Li et al., 2018).

The most studied components that influence the ozonation treatment are ozone dosage (Jung et al., 2017), exposure time to the gas (Camilo Júnior et al., 2019), pH value (Buffle et 
al., 2006), effluent characteristics (Silva and Jardim, 2006; Xu et al., 2002), among others (Galdeano et al., 2018).

This paper therefore evaluated the reduction of the initial values of color, turbidity, chemical oxygen demand, UV abs and $\mathrm{pH}$ variance of the raw leachate sampled from a landfill in Sorriso, MT, by considering the influence of $\mathrm{pH}$ value and contact time with ozone.

\section{MATERIALS AND METHODS}

The raw leachate was sampled at a landfill in Primavera, in the city of Sorriso, Mato Grosso, Brazil. The facility has been in operation since 2011, and receives solid residues from Class IIA, which is non hazardous and non inert, and Class IIB, which is non hazardous and inert. It services more than twelve cities and processes twelve thousand tonnes of residue each month.

In order to treat landfill leachate, there is a system that combines biological and coagulation and flocculation processes (a waste stabilization pond and a physical-chemical treatment). Apart from being licensed by the regulating agencies in charge, the landfill possesses a system for monitoring physical and biotic factors.

The experiments were carried out in the Water and Wastewater Laboratory (LAR) at the Federal University of Mato Grosso (UFMT), in Sinop, Mato Grosso.

The elements that composed the ozonation system were an ozone generator; a bubble column reactor with a sparger on its base to defuse ozone into the landfill leachate; a series of three one-liter beakers, where the first one is responsible for reception and storage of the foam, an event that takes place in the reactor, and the other two are responsible for capturing the exceeding ozone (Figure 1). The seizing of ozone was accomplished by using a potassium iodide solution (KI), and its concentration was $20 \mathrm{~g} \mathrm{~L}^{-1}$. Silicone hoses were also used to connect the beakers.

The ozone generator deployed was the model that uses the Corona effect with atmospheric air, and its nominal production capacity was $0.4 \mathrm{~g} \mathrm{O}_{3} \mathrm{~h}^{-1}$.

The experimental tests were performed following the methodology cited by Guimarães et al. (2010).

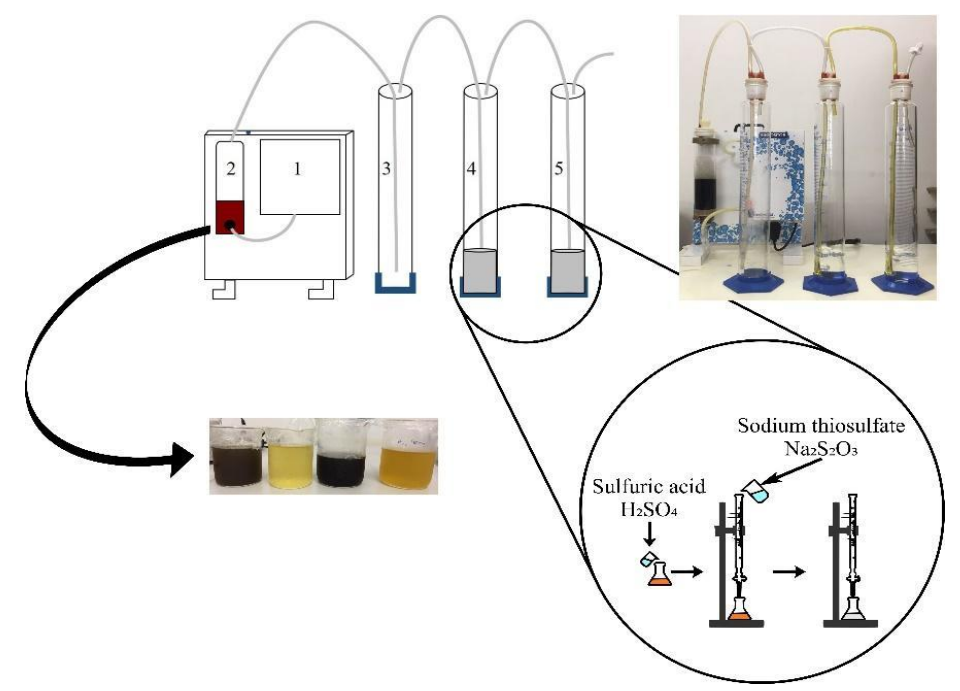

Figure 1. Flowchart of the landfill leachate treatment by ozone [an ozone generator (1); a bubble column reactor to defuse the gas into the leachate (2); a beaker to retain foam (3); and beakers to capture ozone (4 and 5) in a potassium iodide solution]. 
Samples of distilled water (reagent blank) or of landfill leachate had their $\mathrm{pH}$ values set at 7 (or adjusted to 7.3 for water) and 10 . Portions $(0.2 \mathrm{~L})$ of water or effluents were added into the reactor. We added $0.2 \mathrm{~L}$ of potassium iodide (KI), its concentration set at $20 \mathrm{~g} \mathrm{~L}-1$, into the beakers used to capture ozone. The reactor and beakers were then sealed, and the ozonation tests were initiated using the predetermined times of 20, 40, 60, 80 and 100 minutes

After each ozonation time, samples of water or landfill leachate were removed from the reactor, and, for the landfill leachate, we carried out the determination of $\mathrm{pH}$ value, color, turbidity, UV absorbance at $254 \mathrm{~nm}$ (UV abs), and chemical oxygen demand (COD). Afterwards, the values of $\mathrm{pH}$, color, turbidity, and UV abs were obtained using the following pieces of equipment: a $\mathrm{pH}$ meter, a colorimeter, a turbidimeter, and a spectrophotometer, respectively. COD was determined through the heated chemical digestion method.

Then, after the tests, the potassium iodide on the beakers was used to quantify the exceeding ozone (non reactive) through an iodometric titration.

The consumed ozone was determined by the difference between the residual gas contained in the distilled water (reagent blank) and in the effluent.

The characterization of the landfill leachate in regard to the initial parameters is informed in Table 3. We verified that the effluent showed high values of color, turbidity, COD and humic substances (expressed in terms of UV abs), which indicates that the landfill leachate is heavy in pollutants.

The experimental design was entirely random in a $2 \times 5$ factorial design, with two $\mathrm{pH}$ values and five exposure times, resulting in ten samples with three repetitions. The analysis of variance was used, and, when we identified significant effects, we employed Tuckey's test in relation to $\mathrm{pH}$ value, and regression testing in relation to contact time.

\section{RESULTS AND DISCUSSION}

The results from the statistical analysis have shown that there was a significant effect $(\mathrm{p} \leq 0.05)$ from the initial $\mathrm{pH}$ value over the $\mathrm{pH}$ and COD parameters. Also, the interaction among the treatments showed a significant effect $(p \leq 0.05)$ for the removal of UV abs, color and turbidity.

As for the $\mathrm{pH}$ at 7 , we observed an increase in the $\mathrm{pH}$ value from the beginning of the experiment to its end (a negative variation). When the initial $\mathrm{pH}$ was 7 , it is believed that a few intermediate decomposition reactions release $\mathrm{OH}^{-}$ions, which causes the $\mathrm{pH}$ to increase. For the $\mathrm{pH}$ at 10 , we observed a decrease in the $\mathrm{pH}$ value from the beginning of the experiment to its end (a positive variation) (Table 1), which, despite being low, indicates the consumption of $\mathrm{OH}^{-}$ions, probably due to its reaction with ozone chain reactions (von Gunten, 2003).

The average value for the COD parameter, as a function of the initial $\mathrm{pH}$ value (Table 1), showed that a higher removal rate was obtained when $\mathrm{pH}$ was 7 . In neutral $\mathrm{pH}$ values there is, basically, ozone reacting with organic matter. When the $\mathrm{pH}$ value is elevated, there is a tendency to create a hydroxyl radical (a higher standard reduction potential in relation to the molecular ozone), but there is also a tendency for its elimination (Buffle et al., 2006), reducing its availability for indirect reaction.

Table 1. Effect of the $\mathrm{pH}$ treatment regarding the variation of the parameters: $\mathrm{pH}$ value and COD.

\begin{tabular}{ccc}
\hline $\mathbf{p H}$ value & Variation of $\mathbf{p H}(\boldsymbol{\%})^{*}$ & COD removal $(\boldsymbol{\%})$ \\
\hline 7 & -14.5 & 31.9 \\
10 & 1.7 & 17.7 \\
\hline
\end{tabular}

* Negative values point out an addition in $\mathrm{pH}$ variation, and positive values point out a decrease in $\mathrm{pH}$ variation, from the beginning to the end of the experiment. 
For $\mathrm{pH}$ values lower than 7.5 , the decomposition via direct oxidation $\left(\mathrm{O}_{3}\right)$ is highly efficient. For $\mathrm{pH}$ values higher than 7.5, the presence of hydroxide ions initiates the decomposition of ozone in radicals, causing an increase in organic decomposition through indirect oxidation (Takashina et al., 2018; Usepa, 1999). However, for $\mathrm{pH}$ values higher than 9 , the ions found in it (normally bicarbonate and carbonate) act as scavengers of $\bullet \mathrm{OH}$, so they limit indirect oxidative action, reducing the oxidation process (Takeuchi et al., 1997).

Differently, as described by Jung et al. (2017) in their work evaluating saltwater ozonation, the increase of the sample's $\mathrm{pH}$ value ( 7 to 9 ) did not affect the decay of ozonation concentration, due to its quick reaction with bromide ions. The authors describe that the $\mathrm{pH}$ value alteration, however, changed the bromide species, which modified the reactions with ozone without changing its decomposition.

The removal behaviors of color, UV abs and turbidity (in addition to the interaction of $\mathrm{pH}$ value and exposure time) are presented in Figure 2. Higher color removals occurred for contact times above $40 \mathrm{~min}$, with a better tendency of removal for the effluent in $\mathrm{pH}$ value set at 7 (Figure 2A).
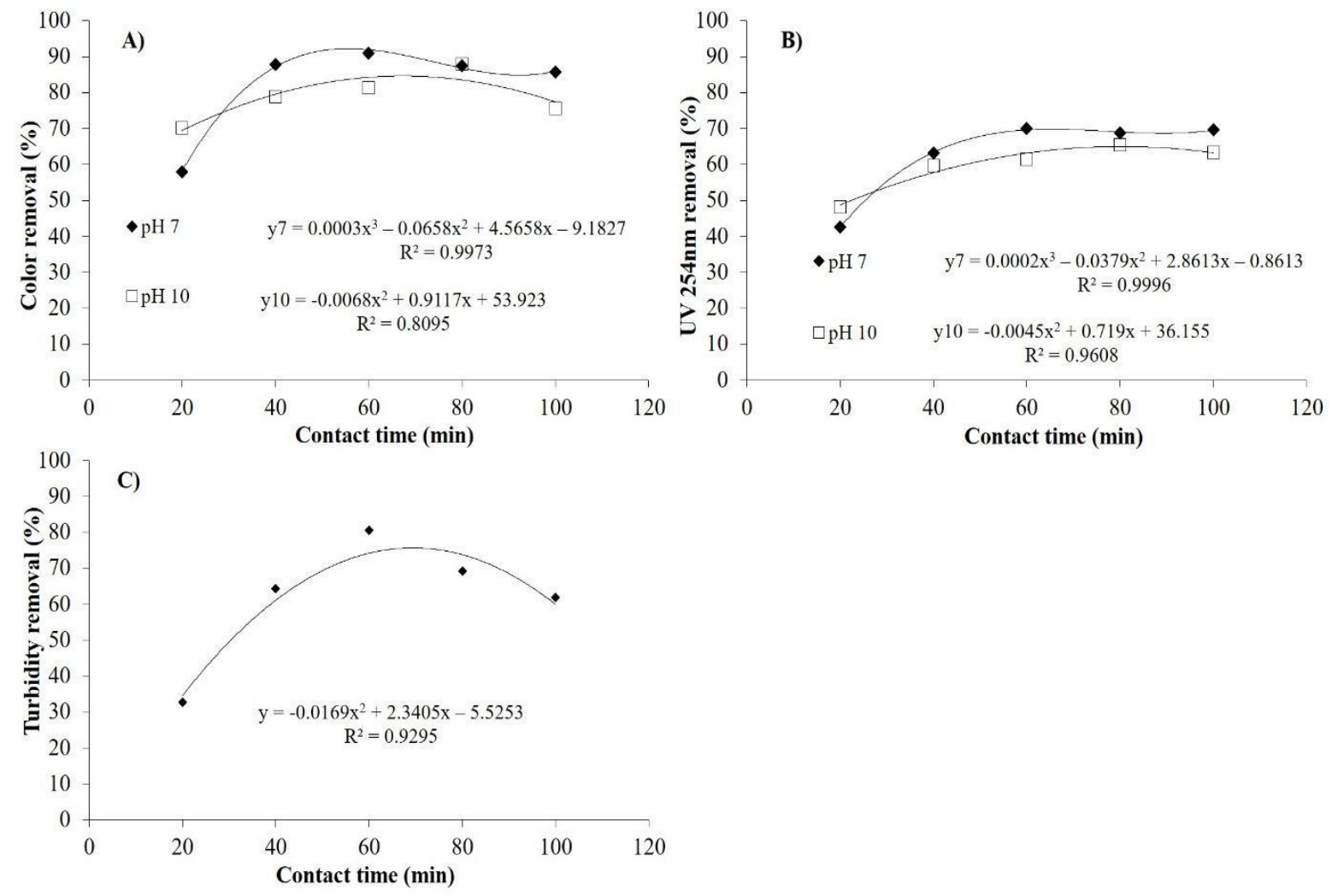

Figure 2. A) Effect of the contact time and the landfill leachate's initial $\mathrm{pH}$ value concerning color removal. B) Effect of the contact time and the leachate's initial $\mathrm{pH}$ value concerning $\mathrm{UV}_{254 \mathrm{~nm}}$ removal. C) Effect of the contact time and the leachate's initial $\mathrm{pH}$ value set at 7 concerning turbidity.

For the UV absorbance parameter, the results were the same as for color removal. However, this parameter showed lower average values of removal (see Figure 2B), which shows that there is a correlation between the parameters. The elements of colors and UV abs are linked to the presence of chromophoric substances in the liquid solution, thus removals or modifications in the chromophoric molecules cause interferences which can be noticed in the visible spectrum (color) and in ultraviolet (UV abs). See Figures 2A and 2B.

Due to the ozonation process applied to the leachate, the sample's initial dark color tends to present a light-yellow color. This reduction of color happens because of the ozone's or the 
$\mathrm{OH}$ radical's attack on the carbon double bond in the chromophore. The procedure results in the formation of the so-called "bleached" products, such as aliphatic acids, aldehydes, and ketones, which are by-products of low-molecular weight, normally biodegradable (Ntampou et al., 2006).

The ultraviolet radiation at $254 \mathrm{~nm}$ is easily absorbed by many organic, inorganic and colloidal compounds that integrate the effluents, which means it is associated with the presence of unsaturated and aromatic compounds (chromophores) in the liquid solution. Therefore, the reduction of UV abs, as well as color removal, is observed through the oxidation of such aromatic compounds (Cortez et al., 2010; Oloibiri et al., 2015).

Results have shown that, both for color (Figure 2A) and UV abs (Figure 2B), there is a tendency for higher removal rates when the timer is set for approximately 60 minutes when $\mathrm{pH}$ value is 7 , reaching removal rates higher than $90 \%$ and around $70 \%$ for color and UV abs, respectively. Regarding the $\mathrm{pH}$ values set at 10 , the tendency for a higher removal occurred at approximately around 70 and 80 minutes. We also observed average removals of $80 \%$ for color, and $60 \%$ for UV abs.

However, we observed that the removal rates for time spans shorter than 70-80 minutes are close to the values of maximum removal. In these cases, it becomes interesting to evaluate ozone production costs. It is necessary to observe production feasibility for longer periods of time, so the parameters can be reduced by $10 \%$.

Then we observed that color and UV abs removal have an increasing rate in the initial times, but, as it advances, the oxidation rate from the organic compounds becomes stable. This same behavior was noticed by Cortez et al. (2010) regarding COD and UV abs, resulting in the hypothesis that the molecular ozone might have reacted with the unsaturated and aromatic compounds, and thus generated compounds that have a slower reaction and which are resistant to complementary oxidation, such as aliphatic acids and aldehydes.

These compounds produced by oxidation do not absorb the ultraviolet spectrum. However, they contribute to COD, which explains the higher removal of absorbance regarding the chemical oxygen demand. Moreover, the landfill leachate's high quantity of organic compounds (Table 3) limits COD removal, as well as possible concentrations of inorganic carbon, which are responsible for consuming $\mathrm{OH}$ radicals, therefore restricting the system's efficiency (Oloibiri et al., 2015).

As for turbidity (Figure 2C), the maximum removal occurred, approximately, at $70 \mathrm{~min}$ $(75 \%)$ for the $\mathrm{pH}$ at 7 . However, we observed that after 40 minutes removals exceeded $60 \%$. Therefore, continuing the ozonation until it reaches 70 minutes may not be a viable alternative. As was suggested for the color and UV abs parameters, it is valid to consider the costs of ozone production.

The turbidity removal when $\mathrm{pH}$ was at 10 did not present any significant regression models ( $\mathrm{p} \leq 0.05$ ), reaching an average removal of around $74 \%$.

The tendency of reduction for turbidity removal (according to the contact time) can have a correlation with precipitating metals, such as iron and manganese; although they were not quantified, these metals were probably part of the composition of the landfill leachate used in the study. The formation of precipitating particles was observed, mainly in higher ozonation times. The precipitated particles stood at the bottom of the reactor. At the end of the ozonation time, the precipitated particles were collected with the samples, which gave the samples turbidity (see Figure 2C).

Iron and manganese are soluble in their lower oxidation states $\left(\mathrm{Fe}^{+2} \mathrm{e} \mathrm{Mn}^{+2}\right)$, but they are relatively insoluble at their higher oxidation states $\left(\mathrm{Fe}^{+3} \mathrm{e} \mathrm{Mn}{ }^{+4}\right)$. This is why these cations can precipitate in the forms of iron hydroxide and manganese hydroxide (Apha et al., 1998).

According to von Gunten (2003), the main oxidation for these inorganic compounds is via direct oxidation, using molecular ozone. As a result, it is possible that a partial oxidation of 
these elements via molecular $\mathrm{O}_{3}$ happened. In addition, the precipitates formed are easily removed using sedimentation and filtration processes after ozonation (Moruzzi and Reali, 2012).

\subsection{Ozone consumption}

The relation of color, turbidity, UV abs, and COD removal, in function of ozone consumption, has shown significant changes $(\mathrm{p} \leq 0.05)$ regarding the isolated treatments, but no significant changes were detected regarding the interaction between them. The variation of $\mathrm{pH}$ value did not show any significant change for the evaluated variables either.

As for color, UV abs, and COD, the highest relation of removal due to ozone mass took place when $\mathrm{pH}$ was 7 , independent of contact time. For turbidity, the highest removal occurred when $\mathrm{pH}$ was set at 10 (Table 2).

Table 2. Effect of the leachate's initial $\mathrm{pH}$ value regarding the removal of the parameters analyzed by milligram of ozone consumed.

\begin{tabular}{|c|c|c|c|c|}
\hline pH value & $\begin{array}{c}\text { Color } \\
\left(\mathrm{mg} \mathrm{Pt}-\mathrm{Co} / \mathrm{mg} \mathrm{O}_{3}\right)\end{array}$ & $\underset{\left(\mathbf{a b s} / \mathrm{mg} \mathrm{O}_{3}\right)}{\mathrm{UV} \text { abs }}$ & 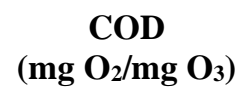 & Turbidity (NTU/mg O $\left.\mathrm{O}_{3}\right)$ \\
\hline 7 & 39.333 & 0.028 & 4.817 & 2.133 \\
\hline 10 & 23.933 & 0.018 & 1.819 & 4.000 \\
\hline
\end{tabular}

Considering the contact time regarding the removal of the parameters analyzed (Figure 3), we observed that the highest ozone mass removals consumed for the parameters color, turbidity, UV abs, and COD took place in the shorter reaction times. This behavior reflects the highest concentration of the elements in the beginning of the treatment, which favors their contact with the oxidizing agent. As the contact time increases, the concentration of the parameters reduces and, consequently, there is less use of the ozone that enters the system (Cortez et al., 2011; Zhang et al., 2018).

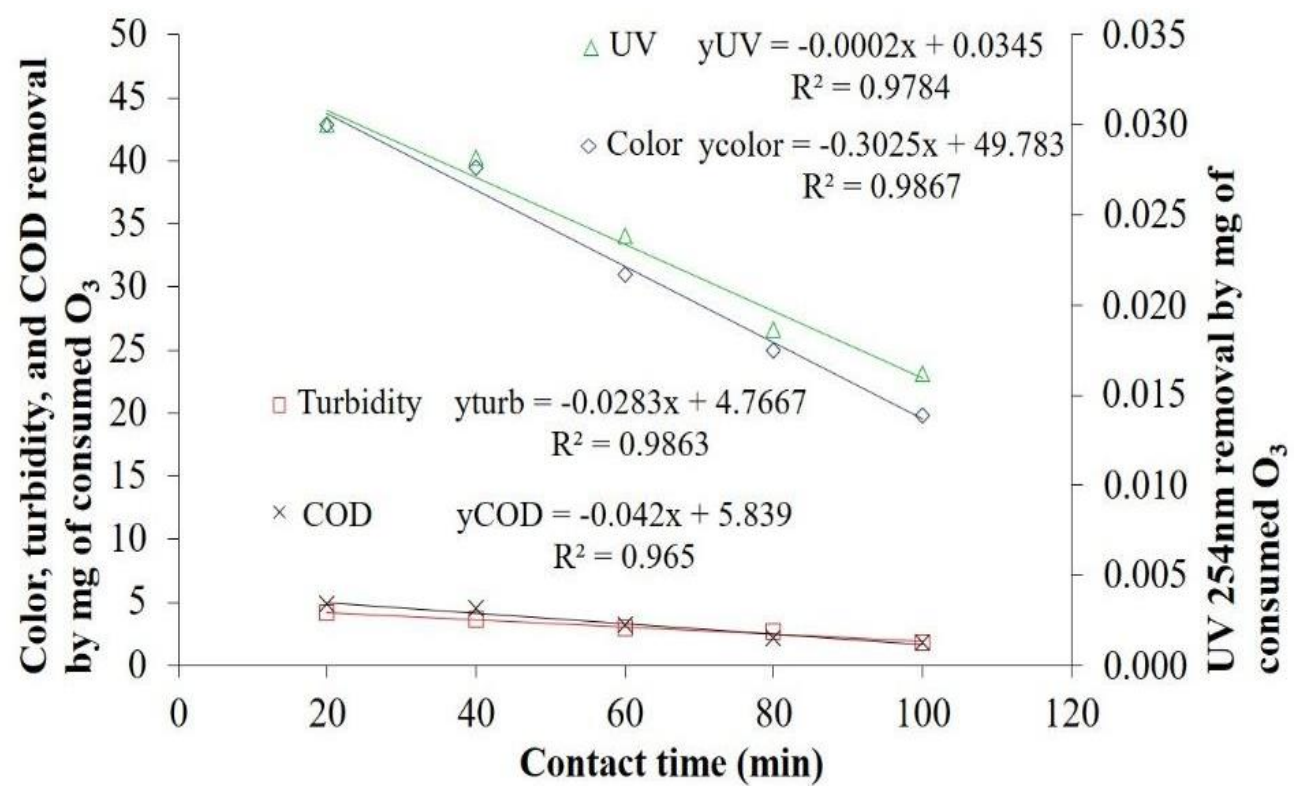

Figure 3. Effect of contact time concerning color, turbidity, UV abs, and COD removals by milligram of ozone consumed. 
The residual values of color, turbidity, UV abs, and COD, determined after the treatment (Table 3), show that the landfill leachate presented high values regarding the parameters analyzed.

Table 3. Residual values obtained for the parameters of raw and treated landfill leachate analyzed, in addition to contact time and initial $\mathrm{pH}$ value.

\begin{tabular}{|c|c|c|c|c|}
\hline \multirow{2}{*}{ Parameters } & \multicolumn{2}{|c|}{ pH 7} & \multicolumn{2}{|c|}{ pH 10} \\
\hline & Raw effluent & Treated effluent & Raw effluent & Treated effluent \\
\hline \multicolumn{5}{|c|}{$20 \mathrm{~min}$} \\
\hline Color (mg Pt-Co L-1) & 14940.00 & 6215.00 & 11870.00 & 3512.00 \\
\hline Turbidity (NTU) & 1104.00 & 743.00 & 1981.00 & 610.00 \\
\hline $\mathrm{pH}$ value & 7.44 & 8.30 & 9.83 & 9.73 \\
\hline $\mathrm{UV}_{254 \mathrm{~nm}}(\mathrm{abs})$ & 13.94 & 7.99 & 12.35 & 6.40 \\
\hline $\operatorname{COD}\left(\mathrm{mg} \mathrm{O}_{2} \mathrm{~L}^{-1}\right)$ & 4321.00 & 3194.00 & 4158.00 & 3393.00 \\
\hline \multicolumn{5}{|c|}{$40 \mathrm{~min}$} \\
\hline Color (mg Pt-Co L-1) & 15020.00 & 1845.00 & 13570.00 & 2858.00 \\
\hline Turbidity (NTU) & 1104.00 & 400.00 & 2618.00 & 770.00 \\
\hline $\mathrm{pH}$ value & 7.35 & 8.51 & 9.79 & 9.70 \\
\hline $\mathrm{UV}_{254 \mathrm{~nm}}(\mathrm{abs})$ & 14.25 & 5.23 & 13.48 & 5.45 \\
\hline $\operatorname{COD}\left(\mathrm{mg} \mathrm{O}_{2} \mathrm{~L}^{-1}\right)$ & 4318.00 & 2497.00 & 4045.00 & 3381.00 \\
\hline \multicolumn{5}{|c|}{$60 \mathrm{~min}$} \\
\hline Color (mg Pt-Co L-1) & 15100.00 & 1346.00 & 13140.00 & 2478.00 \\
\hline Turbidity (NTU) & 1104.00 & 248.00 & 2700.00 & 788.00 \\
\hline $\mathrm{pH}$ value & 7.54 & 8.60 & 9.82 & 9.67 \\
\hline $\mathrm{UV}_{254 \mathrm{~nm}}(\mathrm{abs})$ & 14.66 & 4.37 & 13.36 & 5.17 \\
\hline $\operatorname{COD}\left(\mathrm{mg} \mathrm{O}_{2} \mathrm{~L}^{-1}\right)$ & 4335.00 & 2700.00 & 4042.00 & 3384.00 \\
\hline \multicolumn{5}{|c|}{$80 \mathrm{~min}$} \\
\hline Color (mg Pt-Co L-1) & 14826.00 & 1836.00 & 11880.00 & 1427.00 \\
\hline Turbidity (NTU) & 1104.00 & 366.00 & 2177.00 & 262.00 \\
\hline $\mathrm{pH}$ value & 7.52 & 8.65 & 9.82 & 9.61 \\
\hline $\mathrm{UV}_{254 \mathrm{~nm}}(\mathrm{abs})$ & 13.78 & 4.29 & 12.44 & 4.30 \\
\hline $\mathrm{COD}\left(\mathrm{mg} \mathrm{O}_{2} \mathrm{~L}^{-1}\right)$ & 4691.00 & 3406.00 & 3868.00 & 3122.00 \\
\hline \multicolumn{5}{|c|}{$100 \mathrm{~min}$} \\
\hline Color (mg Pt-Co L-1) & 14826.00 & 2060.00 & 10890.00 & 2656.00 \\
\hline Turbidity (NTU) & 1104.00 & 408.00 & 2188.00 & 840.00 \\
\hline $\mathrm{pH}$ value & 7.52 & 8.72 & 9.86 & 9.57 \\
\hline $\mathrm{UV}_{254 \mathrm{~nm}}(\mathrm{abs})$ & 13.78 & 4.19 & 11.95 & 4.38 \\
\hline $\mathrm{COD}\left(\mathrm{mg} \mathrm{O}_{2} \mathrm{~L}^{-1}\right)$ & 4691.00 & 3609.00 & 4370.00 & 3531.00 \\
\hline
\end{tabular}

Thus, we identified that the values for color, COD and UV abs of the raw effluent were distinct among the $\mathrm{pH}$ values. Those with lower values of $\mathrm{pH}$ showed the highest values in the parameters. As for the turbidity values, we also observed some difference; however, the highest values were for the $\mathrm{pH}$ set at 10. Aziz et al. (2007) investigated the effect of the $\mathrm{pH}$ value regarding color reaction in the landfill leachate's treatment process; they also verified that its 
black color became light-brown, as the effluent's $\mathrm{pH}$ value was reduced or increased, due to the chemical precipitation of humic substances. Therefore, the simple act of increasing or reducing the landfill leachate's $\mathrm{pH}$ value may have promoted a removal of the parameters analyzed.

It is important to highlight that, although the values obtained after the ozonation are high, the treatment did promote a significant reduction of the parameters studied, which can improve or reduce the landfill leachate's post-treatment time.

The ozone integration using other oxidation processes, such as electrochemical and chemical processes (Araújo et al., 2016), are alternatives to achieving the values established by the norm. Also, another interesting alternative is the association between the gas and adsorption processes. Poblete et al. (2017) observed good color and COD removals by using ozone and activated charcoal.

Bila et al. (2004) have shown that the sequence of coagulation-flocculation treatments + ozonation + biological treatment increases the efficiency of the biological treatment stage. Silva and Daniel (2015), by using ozone followed by chlorine disinfection, obtained good removals of biochemical oxygen demand.

\section{CONCLUSION}

Throughout the study, regarding the leachate's hydrogen ionic potential, we observed higher color, COD and UV abs removals when we used $\mathrm{pH}$ value at 7; and, for turbidity, when we set $\mathrm{pH}$ to 10 .

When considering contact time, we verified that, in an exposure of 40 minutes, a good removal for color, turbidity and UV absorbance $\left(\mathrm{UV}_{254 \mathrm{~nm}}\right)$ takes place.

The relation of removal due to ozone consumption decreases as the contact time increases.

Even though the ozonation process has presented good percentages of removal for the parameters analyzed, it must not be applied as the only stage of treatment, since it was not possible to achieve the quality required by the legislation for releasing it into bodies of water. Therefore, it is fundamental to associate it to the methodology of other treatments.

Some alternatives, such as varying the concentration of gas and associating the advanced oxidation processes (AOP) with other advanced or conventional processes, can be interesting from the point of view that it would be a reduction in the effluent load, which would make its treatment less complex.

\section{ACKNOWLEDGEMENTS}

The authors would like to thank the Institute of Agricultural and Environmental Sciences, Federal University of Mato Grosso (UFMT-Sinop), for the financial support.

\section{REFERENCES}

AGOSTINHO, F.; ALMEIDA, C. M. V. B.; BONILlA, S. H.; SACOMANO, J. B.; GIANNETTI, B. F. Urban solid waste plant treatment in Brazil: Is there a net energy yield on the recovered materials? Resources, Conservation and Recycling, v. 73, p. 143-155, 2013. https://doi.org/10.1016/j.resconrec.2013.02.001

ALMEIDA, E.; ASSALIN, M. R.; ROSA, M. A.; DURÁN, N. Tratamento de efluentes industriais por processos oxidativos na presença de Ozônio. Química Nova, v. 27, n. 5, p. 818-824, 2004. http://doi.org/10.1590/S010040422004000500023

APHA; AWWA; WEF. Standard Methods for the Examination of Water and Wastewater. 20. ed. Washington, 1998. 
ARAÚJO, K. S.; ANTONELLI, R.; GAYDECZKA, B.; GRANATO, A. C.; MALPASS, G. R. P. Processos oxidativos avançados: uma revisão de fundamentos e aplicações no tratamento de águas residuais urbanas e efluentes industriais. Revista Ambiente \& Água, v. 11, n. 2, p. 387-401, 2016. https://doi.org/10.4136/ambi-agua.1862

AZIZ, H. A.; ALIAS, S.; ADLAN, M. N.; FARIDAH, A. A. H. ZAHARI, M. N. Colour removal from landfill leachate by coagulation and flocculation processes. Bioresource Technology, v. 98, n. 1, p. 218-220, 2007. https://doi.org/10.1016/j.biortech.2005.11.013

BALAKRISHNAN, P. A.; ARUNAGIRI, A.; RAO, P. G. Ozone generation by silent electric discharge and its application in tertiary treatment of tannery effluent. Journal of Electrostatics, v. 56, n. 1, p. 77-86, 2002. https://doi.org/10.1016/S03043886(02)000311

BILA, D. M.; MONTALVÃO, A. F.; SILVA, A. C.; DEZOTTI, M. Ozonation of a landfill leachate: evaluation of toxicity removal and biodegradability improvement. Journal of Hazardous Materials, v. 117, n. 2-3, p. 235-242, 2004. https://doi.org/10.1016/j.jhazmat.2004.09.022

BRITO, N. N.; SILVA, V. B. M. Processo oxidativo avançado e sua aplicação ambiental. Revista Eletrônica de Engenharia Civil, v. 1, n. 3, p. 36-47, 2012. https://dx.doi.org/10.5216/reec.v3i1.17000

BUFFLE, M.; SCHUMACHER, J.; MEYLAN, S.; JEKEL, M.; VON GUNTEN, U. Ozonation and Advanced Oxidation of Wastewater: Effect of $\mathrm{O}_{3}$ Dose, $\mathrm{pH}$, DOM and HOScavengers on Ozone Decomposition and HO- Generation. Ozone: Science and Engineering, v. 28, n. 4, p. 247-259, 2006. https://doi.org/10.1080/01919510600718825

CAMILO JÚNIOR, O. B.; SANDRI, D.; ALENCAR, E. R.; HEBLING, L. F. Ozonation improves physical attributes in domestic sewage effluent. Revista Ambiente \& Água, v. 14, n. 2, 2019. https://doi.org/10.4136/ambi-agua.2328

CARVALHO, M. C. S.; BORGES, A. C.; PEREIRA, S. P.; HELENO, F. F.; FARONI, L. R. A.; CAMPOS, L. C. Combined use of $\mathrm{O} 3 / \mathrm{H} 2 \mathrm{O} 2$ and $\mathrm{O} 3 / \mathrm{Mn} 2+$ in flotation of dairy wastewater. Revista Ambiente \& Água, v. 13, n. 2, 2018. https://dx.doi.org/10.4136/1980-993X

CORTEZ, S.; TEIXEIRA, P.; OLIVEIRA, R.; MOTA, M. Evaluation of Fenton and ozonebased advanced oxidation processes as mature landfill leachate pre-treatments. Journal Hazardous Materials, v. 92, n. 3, p. 749-755, 2011. https://doi.org/10.1016/j.jenvman.2010.10.035

CORTEZ, S.; TEIXEIRA, P.; OLIVEIRA, R.; MOTA, M. Ozonation as polishing treatment of mature landfill leachate. Hazardous Materials, v. 182, p. 730-734, 2010. https://doi.org/10.1016/j.jhazmat.2010.06.095

DEZOTTI, M. (Coord.). Processos e técnicas para o controle ambiental de efluentes líquidos. Rio de Janeiro: E-papers, 2008. 360p.

GALDEANO, M. C.; WILHELM, A. E.; GOULART, I. B.; TONON, R. V.; FREITAS-SILVA, O.; GERMANI, R.; CHÁVEZ, D. W. H. Effect of water temperature and pH on the concentration and time of ozone saturation. Brazilian Journal of Food Technology, v. 21, 2018. http://dx.doi.org/10.1590/1981-6723.15617 
GEPPERT, M. Avaliação da eficiência de degradação de azo corante amido black 10B em solução aquosa por ozônio. 2018, 221f. Dissertação (Mestrado em avaliação de impactos ambientais) - Universidade La Salle, Canoas, 2018.

GOMES, P. L.; SCHOENELL, E. K. Aplicação de ozônio e ozônio + peróxido de hidrogênio para remoção de compostos recalcitrantes em lixiviados de aterros sanitários. Engenharia Sanitária e Ambiental, v. 15, n. 1, p. 93-98, 2018. https://doi.org/10.1590/s1413-41522018155758

GUIMARÃES, J. R.; ALMEIDA JÚNIOR, R. L.; MANIERO, M. G.; FADINI, P. S. Ozonização em meio básico para redução de cor do licor negro de indústria de celulose de algodão. Engenharia Sanitária e Ambiental, v. 15, n, 1, p. 93-98, 2010. https://doi.org/10.1590/S1413-41522010000100011

JUNG, Y.; HONG, E.; KWON, M.; KANG, J. A kinetic study of ozone decay and bromine formation in saltwater ozonation: Effect of $\mathrm{O} 3$ dose, salinity, $\mathrm{pH}$, and temperature.

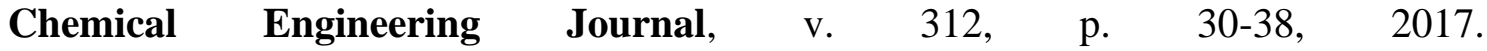
https://doi.org/10.1016/j.cej.2016.11.113

KAWAHIGASHI, F.; MENDES, M. B.; ASSUNÇÃO JÚNIOR, V. G.; GOMES, V. H.; FERNANDES, F.; HIROOKA, E. Y.; KURODA, E. K. Pós-tratamento de lixiviado de aterro sanitário com carvão ativado. Engenharia Sanitária e Ambiental, v. 19, n. 3, p. 236-244, 2014. https://doi.org/10.1590/S1413-41522014019000000652

KUNZ, A.; FREIRE, R. S.; ROHWEDDER, J. J. R.; DURAN, N. Construção e otimização de um sistema para produção e aplicação de ozônio em escala de laboratório. Química Nova, v. 22 , n. 3, p. 425-428, 1999. http://doi.org/10.1590/S0100-40421999000300022

LI, X.; CHEN, W.; MA, L.; WANG, H.; FAN, J. Industrial wastewater advanced treatment via catalytic ozonation with an Fe-based catalyst. Chemosphere, v. 195, p. 336-343, 2018. https://doi.org/10.1016/j.chemosphere.2017.12.080

LOMBARDI, F.; COSTA, G.; SIRINI, P. Analysis of the role of the sanitary landfill in waste management strategies based upon a review of lab leaching tests and new tools to evaluate leachate production. Revista Ambiente \& Água, v. 12, n. 4, p. 543-555, 2017. http://dx.doi.org/10.4136/ambi-agua.2096

METCALF, L.; EDDY, H. P. Tratamento de efluentes e recuperação de recursos. Tradução de Ivanildo Hespanhol e José Carlos Mierzwa. 5. ed. Porto Alegre: McGraw Hill; Bookman, 2015. 2008 p.

MONDARDO, R. I.; SENS, M. L.; MELO FILHO, L. C. Pré-tratamento com cloro e ozônio para remoção de cianobactérias. Engenharia Sanitária e Ambiental, v. 11, n. 4, p. 337 342, 2006. http://doi.org/10.1590/S141341522006000400006

MORUZZI, R. B.; REALI, M. A. P. Oxidação e remoção de ferro e manganês em águas para fins de abastecimento público ou industrial - uma abordagem geral. Revista de Engenharia e Tecnologia, v. 4, n. 1, p. 29-43, 2012.

NTAMPOU, X.; ZOUBOULIS, A. I.; SAMARAS, P. Appropriate combination of physicchemical methods (coagulation/flocculation and ozonation) for the efficient treatment of landfill leachates. Chemosphere, v. 62, n. 5, p. 722-730, 2006. https://doi.org/10.1016/j.chemosphere.2005.04.067 
OLOIBIRI, V.; UFOMBA, I.; CHYS, M.; AUDENAERT, W. T. M.; DEMEESTERE, K.; VAN HULLE, S. W. H. A comparative study on the efficiency of ozonation and coagulation-flocculation as pretreatment to activated carbon adsorption of biologically stabilized landfill leachate. Waste Management, v. 43, p. 335-342, 2015. https://doi.org/10.1016/j.wasman.2015.06.014

POBLETE, R.; OLLER, I.; MALDONADO, M. L.; LUNA, Y.; CORTES, E. Cost estimation of COD and color removal from landfill leachate using combined coffee-waste based activated carbon with advanced oxidation processes. Journal of Environmental $\begin{array}{llllllll}\text { Chemical Engineering, } & \text { v. 5, n. } & \text { 1, } & \text { p. } & \text { 114-121, }\end{array}$ https://doi.org/10.1016/j.jece.2016.11.023

RENOU, S.; GIVAUDAN, J. G.; POULAIN, S.; DIRASSOUYAN, F.; MOULIN, P. Landfill leachate treatment: Review and opportunity. Journal of Hazardous Materials, v. 150, n. 3, p. 468-493, 2008. https://doi.org/10.1016/j.jhazmat.2007.09.077

SILVA, G. H. R.; DANIEL, L. A. Desinfecção de efluente anaeróbio com o uso de ozônio/cloro. Engenharia Sanitária e Ambiental, v. 20, n. 2, p. 279-288, 2015. https://doi.org/10.1590/S1413-41522015020000083662

SILVA, L. M.; JARDIM, W. F. Trends and strategies of ozone application in environmental problems. Química Nova, v. 29, n. 2, p. 310-317, 2006. https://doi.org/10.1590/S010040422006000200023

TAKASHINA, T. A.; LEIFELD, V.; ZELINSKI, D. W.; MAFRA, M. R.; IGARASHIMAFRA, LUCIANA. Application of Response Surface Methodology for Coffee Effluent Treatment by Ozone and Combined Ozone/UV. Ozone: Science \& Engineering, v. 40, n. 4, p. 293-304, 2018. https://doi.org/10.1080/01919512.2017.1417112

TAKEUCHI, Y.; MOCHIDZUKI, K.; MATSUNOBU N.; KOJIMA, R.; MOTOHASHI, H.; YOSHIMOTO, S. Removal of organic substances from water by ozone treatment followed by biological activated carbon treatment. Water Science and Technology, v. 35, n. 7, p. 171- 178, 1997. https://doi.org/10.1016/S0273-1223(97)00128-5

USEPA. Alternative disinfectants and oxidants: guidance manual. Washington, 1999. 328 p.

VON GUNTEN, U. Ozonation of drinking water: Part I. Oxidation kinetics and product formation. Water Research, v. 37, n. 7, p. 1443-1467, 2003. https://doi.org/10.1016/S0043-1354(02)00457-8

VON SONNTAG, C.; VON GUNTEN, U. Chemistry of ozone in water and wastewater treatment from basic principles to applications. Londres: IWA Publishing, 2012. 302 p.

XU, P.; JANEX, M. L.; SAVOYE, P.; COCKX, A.; LAZAROVA, V. Wastewater disinfection by ozone: main parameters for process design. Water Research, v. 36, p. 1043-1055, 2002. https://doi.org/10.1016/S0043-1354(01)00298-6

ZHANG, J.; HUANG, G.; LIU, C.; ZHANG, R.; CHEN, X.; ZHANG, L. Synergistic effect of microbubbles and activated carbon on the ozonation treatment of synthetic dyeing wastewater. Separation and Purification Technology, v. 201, p. 10-18, 2018. https://doi.org/10.1016/J.SEPPUR.2018.02.003 


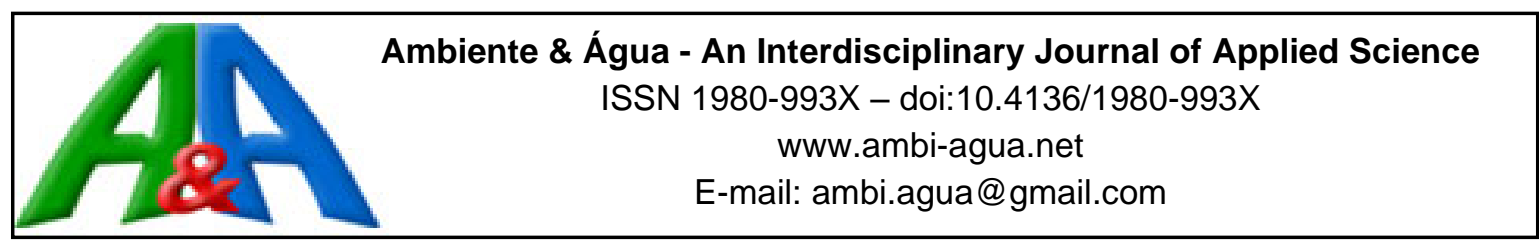

\title{
Biodegradation of nitroaromatic compounds in Red Water by white rot fungi Pleurotus ostreatus and floridae
}

\author{
ARTICLES doi:10.4136/ambi-agua.2594
}

Received: 10 Jun. 2020; Accepted: 15 Sep. 2020

\section{Cristiane Patrícia Kist ${ }^{1}$; ; Claudio Eduardo Scherer $^{2}(\mathbb{D}$; Marlene Soares $^{3}$; ; Marcio Barreto Rodrigues ${ }^{4 *}$}

\begin{abstract}
${ }^{1}$ Programa de Pós-Graduação em Ciência e Tecnologia Ambiental. Universidade Tecnológica Federal do Paraná (UTFPR), Rua Deputado Heitor Alencar Furtado, n 5000, CEP: 81280-340, Curitiba, PR, Brazil. E-mail: criskist_ck@hotmail.com

${ }^{2}$ Programa de Pós-Graduação em Tecnologia de Processos Químicos e Bioquímicos. Universidade Tecnológica Federal do Paraná (UTFPR), Via do conhecimento, Km 1, s/n, CEP: 85503-390, Pato Branco, PR, Brazil. E-mail: claudiorx.scherer@gmail.com

${ }^{3}$ Departamento Acadêmico de Química e Biologia. Programa de Pós-Graduação em Ciência e Tecnologia Ambiental. Universidade Tecnológica Federal do Paraná (UTFPR), Rua Deputado Heitor Alencar Furtado, n 5000, CEP: 81280-340, Curitiba, PR, Brazil. E-mail: marlenesoares@utfpr.edu.br

${ }^{4}$ Departamento Acadêmico de Química. Programa de Pós-Graduação em Tecnologia de Processos Químicos e Bioquímicos. Universidade Tecnológica Federal do Paraná (UTFPR), Via do conhecimento, Km 1, s/n, CEP: 85503-390, Pato Branco, PR, Brazil.

*Corresponding author. E-mail: marciorodrigues@utfpr.edu.br
\end{abstract}

\begin{abstract}
Pleurotus fungi are basidiomycetes that stand out in the degradation of recalcitrant organic compounds such as lignin derivatives and phenolic compounds. The aim of this study was to make a comparative evaluation of the capacity of the Pleurotus ostreatus POS 560 and Pleurotus floridae PSP1 fungi in the degradation of 2,4 and 2,6-dinitrotoluene (DNTs) in effluent from an explosive factory. The characterization of the effluent indicated $318 \mathrm{mg} \mathrm{L}^{-1}$ of DNTs, $246 \mathrm{mg} \mathrm{L}^{-1}$ of COD and toxicity factor for Daphnia magna corresponding to 8 . The conduct of a multivariate study estimated the influence of the variables $\mathrm{pH}$ (5.0 and 6.0), cosubstrate concentration (10 and $20 \mathrm{~g} \mathrm{~L}^{-1}$ of glucose) and species of the fungus Pleurotus (ostreatus and floridae) on the degradation of DNTs, indicating that the variables Fungus and [Glucose] were significant $(\mathrm{p}<0.05)$ presenting effects in the order of $+4.45 \pm 0.26$ and -1.14 \pm 0.26 , respectively. The reproduction of the best efficiency conditions (P. floridae; $\mathrm{pH} 6.0$ and $10 \mathrm{~g} \mathrm{~L}^{-1}$ of glucose $)$ in agitated flasks $\left(100 \mathrm{rpm}, 26^{\circ} \mathrm{C}\right)$ was able to carry out, within 14 days of treatment, the removal of organic matter and toxicity factor in levels on the order of 55 and $50 \%$, respectively, in addition to the complete degradation of DNTs which occurred in the first 120 hours of treatment. In this period, the maximum activity of the peroxidase and Mnperoxidase enzymes was also characterized, suggesting high potential of the bioprocess under study for remediation of effluents contaminated with nitroaromatic compounds.
\end{abstract}

Keywords: DNT biodegradation, explosives factory effluent, white rot fungi. 


\section{Biodegradação de compostos nitroaromáticos em Água Vermelha pelos fungos de degradação branca Pleurotus ostreatus e floridae}

\section{RESUMO}

Os fungos pleurotus são basidiomicetos que se destacam na degradação de compostos orgânicos de natureza recalcitrante, como derivados de lignina e compostos fenólicos. O objetivo deste estudo foi avaliar comparativamente a capacidade dos fungos Pleurotus ostreatus POS 560 e Pleurotus floridae PSP1 na degradação de 2,4 e 2,6-dinitrotolueno (DNTs) em efluente da indústria de explosivos. A caracterização indicou $318 \mathrm{mg} \mathrm{L}^{-1}$ de DNTs, $246 \mathrm{mg} \mathrm{L}^{-1}$ de DQO e fator de toxicidade para Daphnia magna correspondente a 8. A condução de um estudo multivariado estimou a influência das variáveis $\mathrm{pH}(5.0$ e 6.0), concentração de cosubstrato (10 e $20 \mathrm{~g} \mathrm{~L}^{-1}$ de glicose) e espécies do fungo Pleurotus (ostreatus e floridae) sobre a degradação de DNTs, tendo indicado que as variáveis Fungo e [Glicose] se mostraram significativas $(\mathrm{p}<0.05)$ apresentando efeitos da ordem de $+4.45 \pm 0.26$ e $-1.14 \pm 0.26$, respectivamente. A reprodução das melhores condições de eficiência ( $P$. floridae; $\mathrm{pH}$ 6,0 e $10 \mathrm{~g} \mathrm{~L}^{-1}$ de glicose $)$ em frascos agitados $\left(100 \mathrm{rpm}, 26^{\circ} \mathrm{C}\right)$ foi capaz de promover em 14 dias de tratamento remoções de matéria orgânica e fator de toxicidade em níveis da ordem de 55 e $50 \%$, respectivamente, além da completa degradação de DNTs a qual ocorreu nas primeiras 120 horas de tratamento, período durante o qual também foi caracterizada atividade máxima das enzimas peroxidase e Mn-peroxidase, sugerindo alto potencial do bioprocesso em estudo para remediação de efluentes contaminados com compostos nitroaromáticos.

Palavras-chave: biodegradação de DNT, efluente de indústria de explosivos, fungos de degradação branca.

\section{INTRODUCTION}

The nitroaromatic explosives industry produces in its industrial process, especially in the purification stages, wastewater with significant polluting potential, a characteristic especially attributed to the presence of significant amounts of nitroaromatic compounds such as 2,4,6trinitrotoluene 2,4-dinitrotoluene, 2,6-dinitrotoluene mono and polysubstituted amino and nitrophenols, among others (Barreto-Rodrigues et al., 2009). These effluents have a high degree of toxicity and, when in contact with the intestinal microflora of mammalian organisms, are quickly reduced to a more reactive derivative with characteristic carcinogenic and mutagenic potential (Spain et al., 1994). Due to the low biodegradability that these compounds end up transferring to the effluent, their treatment by conventional remediation technologies is limited. For this reason, different alternatives have been proposed, including filtering catalytic ceramics, modified membranes, different types of advanced oxidative processes and process integration (Bhosale et al., 2019; Ali et al., 2019; Bhanot et al., 2020). As an additional alternative, treatment using fungi has already demonstrated the potential to promote extensive degradation of chemical species of environmental relevance (Bennett, 1994).

Fungi are capable of decomposing wood components, being divided into three groups, according to their morphology: white, brown and mild degradation fungi (Bennett, 1994). White degradation fungi decompose the three components of wood - lignin, cellulose, hemicellulose - at similar speeds. This ability is because they produce several extracellular lignocellulolytic enzymes, mainly laccases, manganese peroxidase and versatile peroxidases, being able to act on several xenophobic compounds with lignolytic characteristics (Šrédlová et $a l .$, 2016). In comparison to the enzymatic system of many microorganisms, only the attack of white degrading fungi by specific enzymatic oxidative is able to cause mineralization by the cometabolic process of the aromatic nucleus of the $\mathrm{C}-\mathrm{TNT}$ ring, which generates $\mathrm{CO}_{2}$ and 
carbohydrates, used as a substrate and source of energy and growth (Spain et al., 1994, p. 214).

The fungi of the Pleurotus genus are known as oyster mushrooms and have about 40 species, occupying the third position $(25 \%)$ in annual world production. Examples of this species include Pleurotus pulmonarius, Pleurotus sajor-caju, Pleurotus floridae and Pleurotus ostreatus. These last two are known as "shimeji" and contain high amounts of proteins, carbohydrates, minerals, vitamins and low fat content, being very important commercially (Maity et al., 2011; Wang et al., 2015). Microorganisms of the Pleurotus genus are generally found in tropical and subtropical forests around the world, and can be grown artificially, due to their ability to degrade a wide variety of substrates that contain cellulose, hemicellulose and lignin, as they have different enzymatic complex, such as cellulases, hemicellulases, ligninases, peroxidases, laccases and proteases (Bennett, 1994).

Although several previous studies report the use of Pleurotus species in processes of bioremediation and degradation of different chemical species of environmental relevance, the applications are restricted mainly to $P$. ostreatus, $P$. sajor-caju, $P$. eryngii and $P$ pulmonarius, with few studies with some species like Pleurotus floridae. For example, using Pleurotus ostreatus HAUCC 162, Zhuo et al. (2019) characterized the role of laccase enzyme in the degradation process of textile dyes, Malachite green (MG), Remazol Brilliant Blue R (RBBR), Bromophenol blue (BB) and Methyl orange (MO) and in 24h the decolorization rates were of 91.5\%, 84.9\%, 79.1\%, and 73.1\% for MG (100 $\left.\mathrm{mg} \mathrm{L}^{-1}\right)$, RBBR $\left(100 \mathrm{mg} \mathrm{L}^{-1}\right), \mathrm{BB}\left(100 \mathrm{mg} \mathrm{L}^{-1}\right)$ and MO (100 mg L $\mathrm{m}^{-1}$ ), respectively. Kamida et al. (2005) studied the bioremediation of synthetic effluent (textile dye - indigo) with Pleurotus sajor-caju, and obtained in 14 days of treatment the total removal of the color from the midst. Hadibarata and Kristanti (2013) studied the bioremediation of synthetic fluorene effluent using Pleurotus eryngii, and during 23 days of treatment they obtained complete removal of the contaminant. Zhang et al. (2015) studied the remediation of bisphenol A synthetic effluent $(10 \mathrm{mg} / \mathrm{L})$ by Pleurotus ostreatus, observing total biodegradation after 7 days. Finally, Šrédlová et al. (2016) studied the remediation of polychlorinated biphenyl, obtaining 72 to $80 \%$ removal of the total polychlorinated biphenyl content, after a week of treatment with the Pleurotus ostreatus fungus.

The present work evaluated the potential of Pleurotus floridae and Pleurotus ostreatus for the degradation of nitroaromatic compounds in wastewater from the explosives industry. The scientific contribution and novelty presented is related to the comparison between species of the same fungus applied to the treatment of industrial effluent, since, as mentioned above, most research involving fungi of the genus Pleurotus uses compounds or synthetic effluents as models, and applications with floridae species are relatively scarce.

\section{MATERIAL AND METHODS}

\subsection{Chemicals and supplies}

All chemicals used were of analytical grade and were obtained from Merck, Reagen or Sigma. The wastewater samples were collected from IMBEL Explosives Materials Industry, located in São Paulo State, Brazil. The wastewater resulted from the trinitrotoluene manufacturing process purification stage. After being collected at room temperature, it was stored under refrigeration $\left(4^{\circ} \mathrm{C}\right)$ for later analysis. All experiments used diluted samples $(1: 200)$.

\subsection{Analytical control}

The following parameters were used to determine the pollution potential of the effluent and ensure analytic control of the system:

$U V$-visible spectroscopy (UV-Vis): Spectroscopic analyses were performed on a spectrophotometer Thermal Scientific Evolution 60S model-UV-visible, using quartz cuvettes with an optical path of $1 \mathrm{~cm}$. Absorbance measurements at $K \mathrm{max}=275 \mathrm{~nm}$ were performed to quantify the rate of degradation of nitroaromatic compounds in the effluent. 
Chemical oxygen demand (COD): A sample was refluxed in a strongly acidic solution with a known excess of $\mathrm{K}_{2} \mathrm{Cr}_{2} \mathrm{O}_{7}$. The consumed oxygen was measured against the standard at $600 \mathrm{~nm}$ with a spectrophotometer (APHA et al., 2005).

Gas chromatograph/mass spectrometer analysis: One hundred millimeters (100 mL) of effluent were dried under reduced pressure and the residue was solubilized with methanol chromatographic grade. After treatment with anhydrous sodium sulfate for moisture extraction and filtering on $0.45 \mu \mathrm{m}$ cellulose membrane, it was transferred to a sample vial. The proportional sample amount $(0.4 \mu \mathrm{L})$ was injected into a gas chromatograph/mass spectrometer (Varian 431-GC/210MS) equipped with a capillary column (DB5, $30 \mathrm{~m} \times 0.25 \mathrm{~mm}$, film thickness $0.25 \mu \mathrm{m}$ ), operated from 313 to $573 \mathrm{~K}$ at a programming rate of $20 \mathrm{~K} \cdot \mathrm{min}^{-1}$. The obtained mass spectra were used to identify 2,4 and 2,6-dinitrotoluene involved in the wastewater when compared to authentic standard compounds.

Red water acute toxicity with Daphnia magna: The procedures followed the NBR 12.713 (ABNT, 2009) and evaluated the acute toxicity of samples from wastewater, surface or subterranean waters and from continental soluble chemicals or from chemicals dispersed in the water. The D. magna factor toxicity (FTD) was calculated according to the lowest sample dilution, which presented immobility in not more than $10 \%$ of the organisms.

\subsection{Effluent biotreatment in shake flasks}

Microorganism and inoculum preparation: The ligninolytic P.ostreatus POS 560 and $P$. floridae PSP 1 fungus (Fungibrás/SP) were initially grown on potato dextrose agar (PDA) in Petri dishes at $37^{\circ} \mathrm{C}$ for 7 days and then transferred to the liquid culture (Malt Broth, MB) by punching out $5 \mathrm{~mm}$ of the agar plate with a sterilized self-designed cutter. Twenty disks were used in each flask as standard inoculum.

Red water effluent treatment: After $72 \mathrm{~h}$, the pre-inoculum was filtered through sterile gauze and the fungal biomass $(20 \mathrm{~g})$ was transferred to $250 \mathrm{ml}$ of effluent diluted with distilled water (1:200) and subjected to treatment according to conditions described by factorial planning for a period of 14 days. Samples were collected daily, filtered and analyzed according to parameters described in 2.2.

Experimental Design: A complete $2^{3}$ factorial design with three genuine repetitions was conducted in shaker flasks $\left(100 \mathrm{rpm}, 26^{\circ} \mathrm{C}, 7\right.$ days) to evaluate the effects $\mathrm{X}_{1}$ : fungus species (P.ostreatus and P. Floridae), $\mathrm{X}_{2}: \mathrm{pH}$ (5.0 and 6.0) and $\mathrm{X}_{3}$ : concentration of co-substrate in the form of glucose (10 and $20 \mathrm{~g} \mathrm{~L}^{-1}$ ) on the removal of nitroaromatic compounds as measured by the percentage reduction in absorbance at $K_{\max }=275 \mathrm{~nm}$. For the purpose of statistical calculations, the values of the independent variables were coded in two levels $(-$ and +$)$, as shown in Table 1.

Table 1. Factorial planning matrix and Effects for nitroaromatic removal in Red Water.

\begin{tabular}{|c|c|c|c|c|c|c|c|c|}
\hline \multirow{2}{*}{ Test } & \multicolumn{3}{|c|}{ Codified levels } & \multicolumn{3}{|c|}{ Actual values } & \multirow{2}{*}{\multicolumn{2}{|c|}{ Nitroaromatic Removal (\%) }} \\
\hline & $\mathrm{X}_{1}$ & $\mathrm{X}_{2}$ & $\mathrm{X}_{3}$ & Fungus & $\mathrm{pH}$ & [glucose] $\left(\mathrm{g} \mathrm{L}^{-1}\right)$ & & \\
\hline 1 & -1 & -1 & -1 & P. ostreatus & 5.0 & 10 & 14.3 & \pm 0.53 \\
\hline 2 & +1 & -1 & -1 & P. floridae & 5.0 & 10 & 17.5 & \pm 0.58 \\
\hline 3 & -1 & +1 & -1 & P. ostreatus & 6.0 & 10 & 18.4 & \pm 0.42 \\
\hline 4 & +1 & +1 & -1 & P. floridae & 6.0 & 10 & 21.0 & \pm 0.74 \\
\hline 5 & -1 & -1 & +1 & P. ostreatus & 5.0 & 20 & 15.6 & \pm 0.65 \\
\hline 6 & +1 & -1 & +1 & P. floridae & 5.0 & 20 & 20.9 & \pm 0.74 \\
\hline 7 & -1 & +1 & +1 & P. ostreatus & 6.0 & 20 & 11.7 & \pm 0.75 \\
\hline 8 & +1 & +1 & +1 & P. floridae & 6.0 & 20 & 18.4 & \pm 0.44 \\
\hline
\end{tabular}

$\mathrm{X}_{1}$ : Fungus; $\mathrm{X}_{2}$ : $\mathrm{pH}$ and $\mathrm{X}_{3}$ : Pleurotus fungus specie. 
For better interpretation, a statistical analysis carried out with Statgraphics plus 5.1 software estimated the effects of the variables of interest on the removal rate of nitroaromatic compounds. The results are shown in Table 2, in which it is possible to observe estimated effect values, regression coefficients, interactions with significant and non-significant parameters, in addition to associated errors and level of significance attributed to each parameter. Factors in bold and marked with an asterisk were considered significant for the $95 \%$ confidence interval ( $\mathrm{X}_{1}$ : Fungus, $\mathrm{X}_{3}$ : glucose; interactions $\mathrm{X}_{1} \cdot \mathrm{X}_{3}$ and $\mathrm{X}_{2} \cdot \mathrm{X}_{3}$ ).

Table 2. Effects, regression coefficients and interaction to Red Water biotreatment.

\begin{tabular}{|c|c|c|c|c|c|c|}
\hline Factors & Effect & Effect error & tcalc & $\mathrm{p}$ Value & Coefficient & Coefficient error \\
\hline Average & 17.22 & \pm 0.134 & 128.5 & & 17.225 & \pm 0.067 \\
\hline $\mathbf{X}_{1}$ :fungus* & 4.45 & \pm 0.268 & 16.60 & $0.0000 *$ & 2.225 & \pm 0.134 \\
\hline $\mathrm{X}_{2}: \mathrm{pH}$ & 0.325 & \pm 0.268 & 1.212 & 0.2115 & 0.1625 & \pm 0.134 \\
\hline $\mathbf{X}_{3}:[\text { glucose }]^{*}$ & -1.137 & \pm 0.268 & -4.244 & $0.0002 *$ & -0.5687 & \pm 0.134 \\
\hline$X_{1} . X_{2}$ & 0.225 & \pm 0.268 & 0.8395 & 0.3829 & 0.1125 & \pm 0.134 \\
\hline $\mathbf{X}_{1} \cdot \mathbf{X}_{3} *$ & 1.53 & \pm 0.268 & 5.376 & $0.0001 *$ & 0.7687 & \pm 0.134 \\
\hline $\mathbf{X}_{2 .} \mathbf{X}_{3}^{*}$ & -3.51 & \pm 0.268 & -13.10 & $0.0001 *$ & -1.756 & \pm 0.134 \\
\hline
\end{tabular}

*Statistically significant factors $(\mathrm{p}<0.05) . \mathrm{t}_{\mathrm{tab}} 0.05 ; 24=2.060$.

\section{RESULTS AND DISCUSSION}

\subsection{Multivariate study of red water biotreatment with Pleurotus}

Table 1 shows the tests, coded and real levels, in addition to the results obtained in each experiment carried out with the same experimental errors. The data (responses) obtained based upon the statistical design were assessed by analysis of variance (ANOVA). The homogeneity of variance was checked by Levene's test, and the normal distribution of results was checked using the Shapiro-Wilk test with a 5\% significance level. In general, degradation rates of nitroaromatic compounds ranged from 11.7 to $21 \%$, obtained in tests 4 and 7, which used $P$.

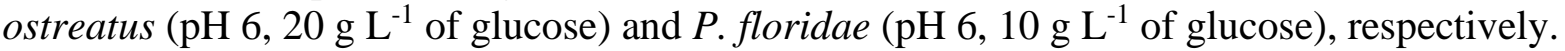

Equation 1 was generated considering only the significant coefficients listed in Table 2 and it explains mathematically how each variable affects the nitroaromatic compounds removal during the biological treatment of red water effluent.

DNT removal $(\%)=17.22+2.22 \mathrm{X}_{1}-0.568 \mathrm{X}_{3}+0.768 \mathrm{X}_{1} \cdot \mathrm{X}_{3}-1.756 \mathrm{X}_{2} \cdot \mathrm{X}_{3}$

As it would be of interest to use Equation 1 as a model for predictive and interpretative purposes, the adjustment of Equation 1 was assessed with the aid of analysis of variance (ANOVA) (Barros Neto et al., 2002) and the results are shown in Table 3. In this context, it can be verified with $95 \%$ confidence that the model is satisfactory. Approximately $95 \%$ of variation around the mean can be verified, in addition, the value for the Fcalc ratio was higher than the Ftab value, suggesting that a regression involving the study variables can be considered significant and adequate to be used for predictive purposes (Box et al., 1978). Thus, Equation 1 was used for the construction of response surfaces "Fungus versus Glucose" $\left(\mathrm{X}_{1} . \mathrm{X}_{3}\right)$ and " $\mathrm{pH}$ versus Glucose" $\left(\mathrm{X}_{2} \cdot \mathrm{X}_{3}\right)$ illustrated in Figure 1 and useful for the interpretation of the interaction of significant effects on the rate of removal of dinitrotoluenes from the red water effluent. 
Table 3. Variance analysis to Red Water Discoloration.

\begin{tabular}{ccccc}
\hline Variance source & GL & SQ & QM & $F_{\text {calc }}$ \\
\hline Model & 6 & 287.633 & 47.938 & 93.5 \\
Lack of adjust & 1 & 2.10125 & 2.10125 & 4.09 \\
Pure error & 24 & 12.305 & 0.512708 & \\
Total & 31 & 302.0392 & & \\
\hline $\mathrm{R}^{2}=95.23 ; \mathrm{F}_{\text {tab }} 0.05 ; 6 ; 25=2.490$ & &
\end{tabular}

Both surfaces illustrated in Figure 1 show a variable [glucose] slope of the response of nitroaromatics removal (\%) from the lower level to the upper level, indicating that lower concentrations of co-substrate provide significant efficiency gains. Regarding $\mathrm{pH}$, although its main effect was not significant, its interaction with the glucose illustrated by surface 1 (a) reveals better efficiency when the tests were conducted at the lowest glucose concentration and the highest $\mathrm{pH}$ level (6.0). These results show that even in treatments of different contaminants, there is a relationship in the efficiency presented by the fungi when influenced by $\mathrm{pH}$ and glucose as the study of Kunjadia et al. (2016) shows, where the efficiency of biodegradation of three types of azo dyes was evaluated by three varieties of white degrading fungi of the genus Pleurotus, namely $P$. ostreatus, $P$. sapidus, and $P$. floridae, which respectively showed 88, 92 and $98 \%$ efficiency in decolorization in 10 days of treatment where the influence by the $\mathrm{pH}$ of the medium in the process of biosorption carried out by the fungi had the maximum removal, being achieved with $\mathrm{pH}$ varying between $6-6.5$ and, outside of that, it was verified that the the removal rates reduce quickly. The influence of sugar, especially glucose as a co-substrate in cultures showed use of up to $0.4 \mathrm{mg} / \mathrm{mL}$ for the $P$. ostreatus compared to the use of 0.30 and $0.35 \mathrm{mg} \mathrm{mL}^{-1}$ for $P$. sapidus, and $P$. floridae, in that order. For the fungus variable, the high slope from the level $(-1)$ to the level $(+1)$ of Figure 1 (b) towards the dependent variable associated with the calculated effect (Table 2) shows a gain of 4.4 percentage points when the $P$. ostreatus is replaced by $P$. floridae.
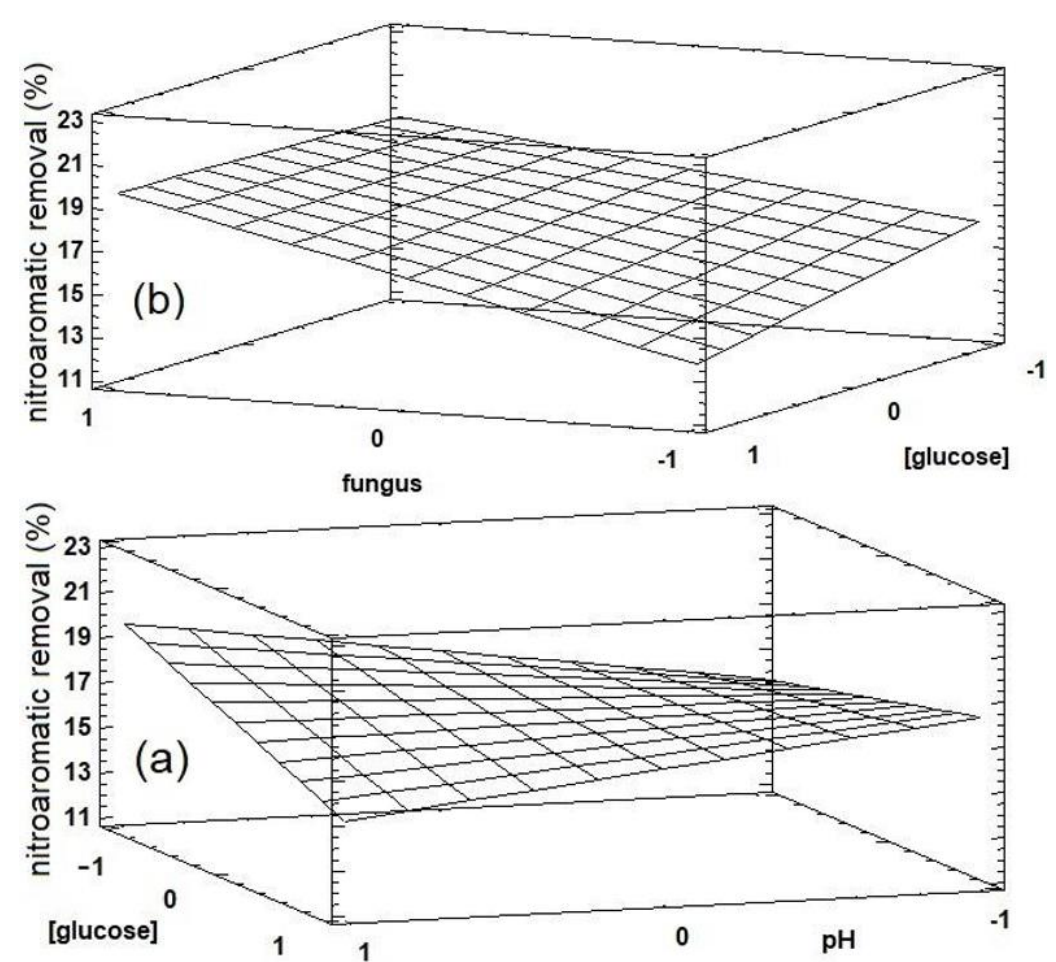

Figure 1. Response surface for the effects on DNT removal: (a) glucose $\mathrm{x} \mathrm{pH}$; (b) fungus $\mathrm{x}$ glucose. 


\subsection{Biological treatment of Red Water effluent in shake flasks}

The reproduction of the conditions of better efficiency identified through the factorial design (species of fungus $P$. floridae; $\mathrm{pH} 6.0$ and $10 \mathrm{~g} \mathrm{~L}^{-1}$ of glucose) in shaker flasks generated the results illustrated in Figure 2 and Table 4.

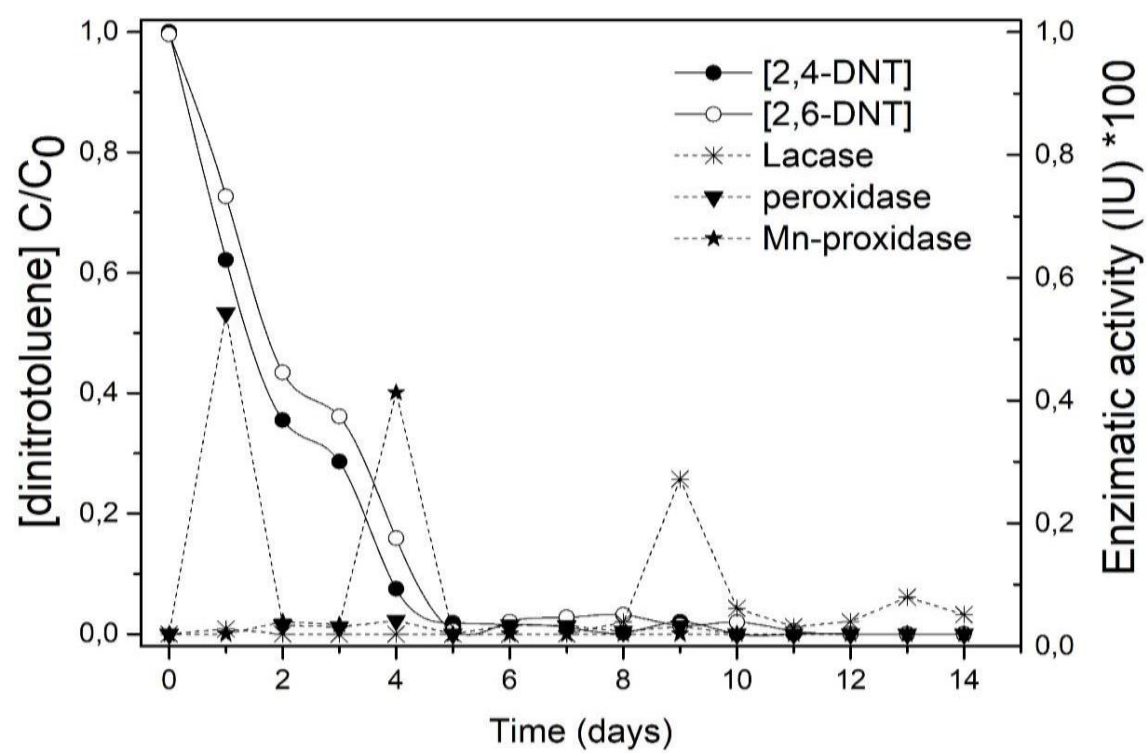

Figure 2. Reduction of dinitrotoluenes and Enzymatic activity of Red Water effluent under treatment in shake flasks with Pleurotus floridae PSP. Experimental conditions: initial $\mathrm{pH}$ of $6.0 ; 10 \mathrm{~g} \mathrm{~L}^{-1}$ glucose and 14 days fermentation time.

Table 4. Physical-chemical parameters and ecotoxicity of red water before and after fungal treatment (dilution 1: 200; treatment time: 14 days).

\begin{tabular}{lcccc}
\hline Parameters & $\begin{array}{c}\text { Untreated } \\
\text { effluent }\end{array}$ & $\begin{array}{c}\text { Treated } \\
\text { effluent }\end{array}$ & $\begin{array}{c}\text { Reduction } \\
(\%)\end{array}$ & $\begin{array}{c}\text { Limits of environmental } \\
\text { legislation* }\end{array}$ \\
\hline COD, mg L & \\
Total dinitroaromatic, $\mathrm{mgL}^{-1}$ & 246 & 135 & 55 & 225 \\
Toxicity Factor & 318 & n.d & 100 & --- \\
& 8 & 4 & 50 & 8 \\
\hline
\end{tabular}

* Brazilian resolution CEMA 81/2010, CONAMA 430/2011 (CEMA, 2010; CONAMA, 2011); n.d: not detected.

The complete removal of nitroaromatic compounds occurred in 5 days of treatment (120 hours) and was related to the activity of the enzyme peroxidase and Mn-peroxidase, which presented maximum activity on the first and fourth days, respectively, coinciding with the periods of higher removal of 2,4 and 2,6-dinitrotoluene. Additionally, the laccase enzyme was also detected, but only after the ninth day of treatment; therefore, its performance seemed to be more related to the degradation of possible intermediates of 2,4 and 2,6-DNT. Such enzymes are recognized for their ability to break down lignin and its derivatives, and also other types of xenobiotic compounds such as pesticides, hormones, drugs and nitroaromatic compounds (Morsi et al., 2020). For example, Levin et al. (2016) obtained 98.4\% removal of 4-nitrophenol (70 $\mathrm{mg} \mathrm{L}^{-1}$ aqueous solution) with Trametes versicolor in 4 days of treatment, the present study also observed the importance of the process performance of the laccase and Mn-peroxidase and peroxidase enzymes. Bettin et al. (2019) also found activities of several phenoloxidases, including laccase in the degradation of phenol in aqueous solution. 
As shown in Table 4, in addition to the complete removal of 2,4 and 2,6-dinitroaromatics, the data suggests that the enzymatic activity shown by Pleurotus floridae was also sufficient to, in 14 days of treatment, remove organic matter and toxicity factor for Daphnia magna at levels in the order of 55 and $50 \%$, respectively. Although the contribution of the adsorption / biosorption processes in the mycelium in relation to biodegradation has not been evaluated, the results reveal that fungal biotreatment promoted a sufficient reduction in the levels of the monitored parameters, making them compatible with the limits provided for in the current environmental legislation. An analysis of the efficiency of Red Water treatment processes available in the scientific literature (Table 5) reveals that physical (adsorption) and chemical (electrochemical) processes present, in comparison to the results obtained in this work, equivalent performances, which can also reach $100 \%$ of removal of DNT, however, in shorter intervals of treatment time (between 3 and 30 hours). On the other hand, it is important to highlight that such processes generally have limitations related to the need to dispose of contaminated phases in the case of adsorbents, in addition to the typical complexity of electrochemical processes, which hinder scaling up operations. In comparison to the biological process with immobilized microorganisms, the results of which are also illustrated in Table 5, the present study required less treatment time for relatively greater removal of the DNT (5 days). Finally, it should be noted that the fact that the \% of COD removal (55\%) was inferior to the other treatments may be related to the residual cosubstrate (glucose) present in the effluent after treatment.

Table 5. Performance of treatment process for Red Water treatment.

\begin{tabular}{|c|c|c|c|c|}
\hline Process & $\begin{array}{l}\text { Experimental } \\
\text { Conditions }\end{array}$ & $\begin{array}{l}\text { Treatment } \\
\text { time }\end{array}$ & $\begin{array}{l}\text { Removal } \\
\text { Efficiency }\end{array}$ & Ref. \\
\hline $\begin{array}{l}\text { Adsorption in Activated } \\
\text { Coque (AC) }\end{array}$ & $\begin{array}{c}160 \mathrm{~g} \mathrm{~L}^{-1} \mathrm{AC}, \mathrm{pH} \\
6.28,20^{\circ} \mathrm{C}, \text { red water dilution } \\
1: 100\end{array}$ & $3 \mathrm{~h}$ & $\begin{array}{l}64.8 \% \text { COD } \\
84 \% \text { DNT }\end{array}$ & $\begin{array}{l}\text { Zhang et } \\
\text { al. }(2011)\end{array}$ \\
\hline $\begin{array}{l}\text { Electrochemical } \\
\text { Treatment (Ti/IrO2) }\end{array}$ & $\begin{array}{l}\text { Anodic } \mathrm{Ti} / \mathrm{IrO}_{2} \text { electrode and } \mathrm{Ti} \\
\text { cathode. Red water dilution 1:100 }\end{array}$ & 30 hours & $\begin{array}{l}68.5 \% \text { COD } \\
100 \% \mathrm{DNT}\end{array}$ & $\begin{array}{l}\text { Jiang et al. } \\
\quad(2018)\end{array}$ \\
\hline $\begin{array}{l}\text { Immobilized ana/aerobic } \\
\text { microbial filters }\end{array}$ & $\begin{array}{c}\text { upflow, Bionetix B925 } \\
\text { microorganisms, red water dil. } \\
\text { 1:200 }\end{array}$ & $\begin{array}{l}25 \text { days } \rightarrow \\
100 \text { days } \rightarrow\end{array}$ & $\begin{array}{l}88 \% \mathrm{DNT} \\
77 \% \mathrm{COD}\end{array}$ & $\begin{array}{l}\text { Zhang et } \\
\text { al. (2015) }\end{array}$ \\
\hline Fungal biotreatment & $\begin{array}{l}10 \mathrm{~g} \mathrm{~L}^{-1} \text { glucose, } \mathrm{pH} 6, P . \text { floridae } \\
\text { fungal, red water dilution 1:200 }\end{array}$ & $\begin{array}{l}5 \text { days } \rightarrow \\
14 \text { days } \rightarrow\end{array}$ & $\begin{array}{l}100 \% \text { DNT } \\
55 \% \text { COD } \\
50 \% \text { toxicity }\end{array}$ & This work \\
\hline
\end{tabular}

\section{CONCLUSIONS}

The statistical analysis of the factorial design indicated that the variables of greatest influence on the degradation of 2,4 and 2,6-dinitrotoluene were the concentration of cosubstrate [Glucose] and species of fungus. Treatability studies conducted in an optimized condition ( $P$. floridae, initial $\mathrm{pH}$ of 6.0 and $10 \mathrm{~g} \mathrm{~L}^{-1}$ glucose) revealed significant performance for the reduction of chemical oxygen demand, toxicity factor for Daphnia magna and also for the total removal of dinitroaromatic compounds constituents of the Red Water effluent. Additionally, it was possible to infer that the observed mechanism of degradation of DNTs is directly related to the activity of identified phenoloxidase enzymes, especially peroxidase and $\mathrm{Mn}$-peroxidase. These results suggest the potential of the bioprocess studied for applications in the treatment of effluents from the nitroaromatic explosives industry. 


\section{ACKNOWLEDGMENTS}

The authors would like to thank UTFPR, Câmpus Pato Branco, CAPES and the Analysis Center availability for the use of the laboratories and for the analysis carried out.

\section{REFERENCES}

ABNT. NBR 12713: Ecotoxicologia aquática - Toxicidade aguda - Método de ensaio com Daphnia spp (Crustacea, Cladocera). Rio de Janeiro, 2009.

ALI, I.; HAN, G.; KIM, J. Reusability and photocatalytic activity of bismuth-TiO2 nanocomposites for industrial wastewater treatment. Environmental Research, v. 170, p. 222-229, 2019. https://doi.org/10.1016/j.envres.2018.12.038

APHA; AWWA; WEF. Standard Methods for the Examination of Water and Wastewater. 21. ed. Washington, 2005.

BARRETO-RODRIGUES, M.; SILVA, F. T.; PAIVA, T. C. B. Characterization of wastewater from the Brazilian TNT industry. Journal of Hazardous Materials, v. 164, n. 1, p. 385388, 2009. https://doi.org/10.1016/j.jhazmat.2008.07.152

BARROS NETO, B.; SCARMÍNIO, S.; BRUNS, R. E. Como fazer experimentos: pesquisa e desenvolvimento na ciência e na indústria. 2. ed. Campinas: UNICAMP, 2002. 401 p.

BENNET, J. W. Prospects for fungal bioremediation of TNT munition waste. International $\begin{array}{lllllllll}\text { Biodeterioration } \& \text { Biodegradation, } & \text { v. } 34, & \text { n. } & 1, & \text { p. } & 21-34, & 1994 .\end{array}$ https://doi.org/10.1016/0964-8305(95)00001-1

BETTIN, F.; COUSSEAU, F.; MARTINS, H.; BOFF, N. A.; SZACCARIA, S.; SILVEIRA, M. M.; DILLON, A. J. P. Phenol removal by laccases and other phenol oxidases of Pleurotus sajor-caju PS-2001 in submerged cultivations and aqueous mixtures. Journal $\begin{array}{llllll}\text { of Environmental Management, } & \text { v. 236, p. 581-590, }\end{array}$ https://doi.org/10.1016/j.jenvman.2019.02.011

BHANOT, P.; CELIN, S. M.; SREEKRISHNAN, T. R.; KALSI, A.; SAHAI, S. K.; SHARMA, P. Application of integrated treatment strategies for explosive industry wastewater-A critical review. Journal of Water Process Engineering, v. 35, 2020. https://doi.org/10.1016/j.jwpe.2020.101232

BHOSAlE, V. K.; CHANA, H. H.; KAMBLE, S. P.; KULKARNI, P. S. Separation of nitroaromatics from wastewater by using supported ionic liquid membranes. Journal of Water Process Engineering, v. 32, 2019. https://doi.org/10.1016/j.jwpe.2019.100925

BOX, G. E. P.; HUNTER, W. G.; HUNTER, J. S. Statistics for experimenters. An introduction to design, data analysis and model building. New York: Wiley, 1978.

CONAMA (Brasil). Resolução nº 430 de 13 de maio 2011. Dispõe sobre as condições e padrões de lançamento de efluentes, complementa e altera a Resolução $n^{\circ} 357$, de 17 de março de 2005, do Conselho Nacional do Meio Ambiente-CONAMA. Diário Oficial [da] União: seção 1, Brasília, DF, n. 92, p. 89, 16 maio 2011.

CONSELHO ESTADUAL DO MEIO AMBIENTE (PR). Resolução CEMA n81 de 19/10/2010. Dispõe sobre Critérios e Padrões de ecotoxicidade para o Controle de Efluentes Líquidos lançados em águas superficiais no Estado do Paraná. Diário Oficial [do] Estado, Curitiba, 19 out. 2010. 
HADIBARATA, T.; KRISTANTI, R. A. Potential of a white-rot fungus Pleurotus eryngii F032 for degradation and transformation of fluorene. Fungal Biology, v. 118, n. 2, p. 222-227, 2013. https://doi.org/10.1016/j.funbio.2013.11.013

JIANG, N.; ZHAO, Q.; XUE, Y.; XU, W.; YE, Z. Removal of dinitrotoluene sulfonate from explosive wastewater by electrochemical method using Ti/IrO2 as electrode. Journal of $\begin{array}{lllll}\text { Cleaner Production, } & \text { v. } & 188, & \text { p. }\end{array}$ https://doi.org/10.1016/j.jclepro.2018.04.030

KAMIDA, H. M.; DURRANT, L. R.; MONTEIRO, R. T. R.; ARMAS, E. D. Biodegradação de efluente têxtil por Pleurotus sajor-caju. Química Nova, v. 28, n. 4, p. 629-632, 2005. https://doi.org/10.1590/S0100-40422005000400014

KUNJADIA, P. D.; SANGHVI, G. V.; KUNJADIA, A. P.; MUKHOPADHYAY, P. N.; DAVE, G. S. Role of ligninolytic enzymes of white rot fungi (Pleurotus spp.) grown with azo dyes. SpringerPlus, v. 5, p. 1487, 2016. http://dx.doi.org/10.1186/s40064-016-3156-7

LEVIN, L.; CARABAJAL, M.; HOFRICHTER, M.; ULLRICH, R. Degradation of 4nitrophenol by the white-rot polypore Trametes versicolor. International $\begin{array}{lllllll}\text { Biodeterioration } \quad \text { \& } & \text { Biodegradation, } & \text { v. 107, }\end{array}$ https://doi.org/10.1016/j.ibiod.2015.11.023

MAITY, K. K.; PATRA, S.; DEY, B.; BHUNIA, S. K.; MANDAL, S.; DAS, D.; MAJUMDAR, D. K.; MAITI, S.; MAITI, T. K.; ISLAM, S. S. A heteropolysaccharide from aqueous extract of an edible mushroom, Pleurotus ostreatus cultivar: structural and biological studies. Carbohydrate Research, v. 346, n. 2, p. 366-372, 2011. https://doi.org/10.1016/j.carres.2010.10.026

MORSI, R.; BILAL, M.; IQBAL, H. M. N.; ASHRAF, S. S. Laccases and peroxidases: The smart, greener and futuristic biocatalytic tools to mitigate recalcitrant emerging pollutants. Science of The Total Environment, v. 714, p. 136572, 2020. https://doi.org/10.1016/j.scitotenv.2020.136572

SPAIN, J. C.; HUGUES, J. B.; KNACKMUSJ, H. Biodegradation of nitroaromatic compounds and explosives. Boca Raton: Lewis Publishers, 1994. 451 p. http://dx.doi.org/10.1201/9781420032673

ŠRÉDLOVÁ, K.; KŘESINOVÁ, Z.; CAJTHAML, T. Biodegradations of polychlorinated biphenyls by Pleurotus ostreatus. New Biotechnology, v. 33, n. 2016, p. S134-S135, 2016. http://dx.doi.org/10.1016\%2Fj.nbt.2016.06.1189

WANG, S.; XU, F.; LI, Z.; ZHAO S.; SONG, S.; RONG, C.; GENG, X.; LIU, Y. The spent mushroom substrates of Hypsizigus marmoreus can be an effective component for growing the oyster mushroom Pleurotus ostreatus. Scientia Horticulturae, v. 186, p. 217-222, 2015. https://doi.org/10.1016/j.scienta.2015.02.028

ZHANG, C.; MINGZHU, L.; XIAOYAN, C.; MINGCHUN, L. Edible fungus degrade bisphenol A with no harmful effect on its fatty acid composition. Ecotoxicology and $\begin{array}{llllll}\text { Environmental Safety, } & \text { v. } & 118, & \text { p. }\end{array}$ https://doi.org/10.1016/j.ecoenv.2015.04.020

ZHANG, M.; LIU, G.; SONG, K.; WANG, Z.; ZHAO, Q.; LI, S.; YE, Z. Biological treatment of 2,4,6-trinitrotoluene (TNT) red water by immobilized anaerobic-aerobic microbial filters. Chemical Engineering Journal, v. 259, p. 876-884, 2015. https://doi.org/10.1016/j.cej.2014.08.041 
ZHANG, M.; ZHAO, Q.; YE, Z., Organic pollutants removal from 2,4,6-trinitrotoluene (TNT) red water using low cost activated coke. Journal of Environmental Sciences, v. 23, p.1962-1969, 2011. https://doi.org/10.1016/S1001-0742(10)60619-5

ZHUO, R.; ZHANG, J.; YU H.; MA, F.; ZHANG, X. The roles of Pleurotus ostreatus HAUCC 162 laccase isoenzymes in decolorization of synthetic dyes and the transformation $\begin{array}{llrlll}\text { pathways. } & \text { Chemosphere, } & \text { v. } 234, & \text { p. }\end{array}$ https://doi.org/10.1016/j.chemosphere.2019.06.113 


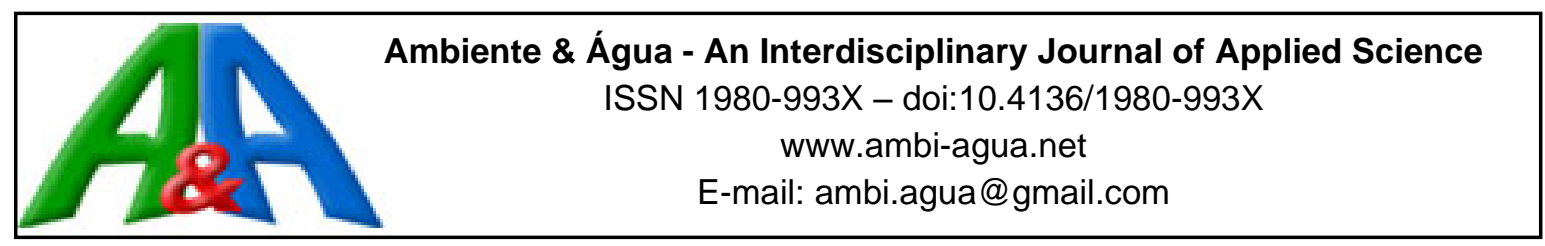

\title{
Mixed greywater treatment for irrigation uses
}

\author{
ARTICLES doi:10.4136/ambi-agua.2599
}

Received: 15 Jun. 2020; Accepted: 08 Oct. 2020

\begin{abstract}
Eli Morales Rojas ${ }^{1 * i D}$; Jesús Rascón ${ }^{1}{ }^{\mathbb{D}}$; Lenin Quiñones Huatangari2 ${ }^{\circledR}$; Segundo Chavez Quintana1 ${ }^{1 D}$; Manuel Oliva1(id); Manuel Emilio Milla Pino ${ }^{3}$

${ }^{1}$ Instituto de Investigación para el Desarrollo Sustentable de Ceja de Selva. Universidad Nacional Toribio Rodríguez de Mendoza de Amazonas (UNTRM), Calle Higos Urco, n 342-350-356, 01001,

Chachapoyas, Amazonas, Peru. E-mail: jesus.rascon@untrm.edu.pe, segundo.quintana@untrm.edu.pe, manuel.oliva@untrm.edu.pe

${ }^{2}$ Facultad de Ingeniería de Industrias Alimentarias. Universidad Nacional de Jaén (UNJ), Jirón Cuzco, n² 250, 06801, Jaén, Cajamarca, Peru. E-mail: lenin.quinones@unj.edu.pe

${ }^{3}$ Facultad de Ingeniería Civil. Universidad Nacional de Jaén (UNJ), Jirón Cuzco, n ${ }^{\circ}$ 250, 06801, Jaén, Cajamarca, Peru. E-mail: memilla22@yahoo.com.mx

*Corresponding author. E-mail: eli.morales@untrm.edu.pe
\end{abstract}

\begin{abstract}
Water contamination comes from many different sources, including, among others, factories, sewage treatment plants, mining activities (heavy metals), food-processing waste, agriculture runoff, animal waste, disposal of personal care products, and household chemicals. Therefore, the reuse of wastewater has become a fundamental strategy for sustainable water management and maintaining environmental quality. In this sense, this research presents a simple and economic alternative to solving the problems caused by greywater, resulting from laundry activities. This paper evaluates a mixed system for the treatment of greywater. The mixed system has physical filters that are composed of river stone, concrete, river sand, and coal. A bioremediation technique is also evaluated, involving two types of aquatic plants, watercress (Nasturtium officinale L.) and duckweed (Lemma minor L.). This study showed significant differences in $\mathrm{pH}$ reduction, from 9.56 to 7.50 , total suspended solids (TSS), from $1742.00 \mathrm{mg} / \mathrm{L}$ to $298.50 \mathrm{mg} / \mathrm{L}$, phosphates, from $1.12 \mathrm{mg} / \mathrm{L} \mathrm{PO}_{4}{ }^{3-}$ to $0.31 \mathrm{mg} / \mathrm{L} \mathrm{PO}_{4}{ }^{3-}$, and chemical oxygen demand (COD), from $472.38 \mathrm{mg} / \mathrm{L}$ to $8.52 \mathrm{mg} / \mathrm{L}$. Thus, the results indicate that this system is efficient for the reuse of grey water for irrigation uses. Moreover, each parameter, with the exception of dissolved oxygen and total suspended solids (TSS), meets the maximum limits set by the Environmental Quality Standards for Category 3: irrigation water for vegetables and animal beverages and the FAO irrigation water standards.
\end{abstract}

Keywords: biological filter, detergents, macrophytes, physical filter, water quality.

\section{Sistema misto de tratamento de águas cinzas para irrigação}

\section{RESUMO}

As atividades pelas indústrias, população urbana e rural, são fontes mais frequentes na poluição de água, devido nisso tem se tornado necessário, principalmente a reutilização das águas resíduas como uma estratégia fundamental. Nesse sentido esta pesquisa apresenta uma alternativa simples e econômica para solucionar os problemas causados pela água cinzas das atividades de lavanderia doméstica, com o objetivo de avaliar um sistema misto de tratamento de água cinza. Para isso foi estabelecido um sistema misto com filtração física, compostos de pedra de rio, concreto, areia de rio e carvão, seguido pela Biorremediação com duas plantas 
aquáticas, agrião (Nasturtium officinale L.) e lentilha d'água (Lemma minor L.). Os resultados tiveram diferenças significativas na redução do $\mathrm{pH}$ de 9.56 até 7.50, os sólidos suspensos totais (SST) de $1742.00 \mathrm{mg} / \mathrm{L}$ até $298.50 \mathrm{mg} / \mathrm{L}$, os fosfatos de $1,12 \mathrm{mg} / \mathrm{L} \mathrm{PO}_{4}{ }^{3-}$ até $0,31 \mathrm{mg} / \mathrm{L} \mathrm{PO}_{4}{ }^{3-}$ e demanda química de oxigênio (DQO) de $472,38 \mathrm{mg} / \mathrm{L}$ até $8,52 \mathrm{mg} / \mathrm{L}$, por tanto indicam que o sistema é eficiente para o reuso da água cinzas com fim de irrigação. Finalmente, todos os parâmetros, a diferença do oxigênio dissolvido e os sólidos suspensos totais (SST), cumprem com os limites máximos permitidos pelos padrões de qualidade ambiental para a categoria três: água de irrigação para vegetais e bebidas de animais e os padrões para irrigação pela FAO.

Palavras-chave: detergentes, filtro biológico, filtro físico, macrófitas, qualidade da água.

\section{INTRODUCTION}

Water is one of the essential resources for the development of natural life in all its forms (Cai et al., 2016). However, the importance of this resource has not been taken into account until the end of the 19th century, when it was discovered as the origin of numerous water-related infectious diseases (Abellán, 2017). Moreover, the scarcity and deterioration of water resources have been related to anthropological activities, for example, poor agriculture practices, livestock, and mining, along with accelerated industrial development and rapid population growth (Bwapwa, 2018). All these factors lead to health problems due to deficient water consumption (Guzmán et al., 2016). In developing countries, such as Peru, most diseases are caused by poor water supply (Ferro-Mayhua et al., 2019).

The service of water supply and sanitation is a major problem in Peru (Calzada et al., 2017). Accordingly, by the beginning of 2018, an estimated $10.6 \%$ of the Peruvian population lacked access to drinking water services in the public system. Furthermore, the inadequate disposal of greywater outside the sewerage system is of great concern. As a result, there is an increase in the proliferation of vector-borne diseases that affect the most vulnerable population (Gutierrez-Espino and Romero-Cóndor, 2018). Greywater or sullage is the result of laundry activities, showers, baths, hand basins, and washing machines. These waste waters usually have hazardous contaminants such as phosphate, a typical compound in detergents, which causes the eutrophication of water bodies (Fowdar et al., 2017; Pérez-Díaz et al., 2019).

Those water issues are a major concern in the search for new supply sources and treatment systems, as well as finding alternatives to mitigate the environmental impacts caused by the inadequate disposal of greywater. In fact, water is a valuable resource that must be preserved in order to ensure a permanent supply for a sustainable use. There are a large number of techniques for treating wastewater, which range from conventional techniques, mostly physical and chemical, such as sedimentation, filtration or chlorination, to alternative techniques, generally physical and biological, such as bioremediation or filtration involving inert material such as sand or gravel (Ghernaout et al., 2017; Poirier et al., 2019). Alternative techniques, although not generally used by both national and local government bodies, may be part in the response to greywater treatment in rural or low-finance areas, as they are proven to be efficient in removing organic and inorganic pollutants and pathogenic organisms (Boczkaj and Fernandes, 2017).

Regarding alternative treatments, bioremediation is one of the most important techniques that is increasingly used due to its easy and simple use and its friendliness to the environment (Azubuike et al., 2016). These techniques usually involve planting emergent plants, such as watercress (Nasturtium officinale L.); but in some cases, organisms such as worms have also been considered. It has been proven that the use of Californian worms (Eisenia fetida, Savigny, 1826) or water hyacinth (Eichhornia crassipes (Mart.) Solms) is highly effective in treating and purifying greywater, especially in terms of organic matter parameters which include

Rev. Ambient. Água vol. 15 n. 6, e2599 - Taubaté 2020 
biochemical oxygen demand $\left(\mathrm{BOD}_{5}\right)$ or chemical oxygen demand (COD) (Reyes Farje and Morales Rojas, 2019).

In this sense, this work proposes a mixed treatment system based on bioremediation and filtration techniques to treat greywater which is generated in a building, testing the evolution of the physicochemical parameters throughout the system. Furthermore, we analyze the spatial variation of the physicochemical parameters in the system and, finally, determine whether the parameters meet national and international regulations and standards regarding water usage in the irrigation of vegetables.

\section{MATERIALS AND METHODS}

\subsection{Study Area}

The experiment was conducted in the building "La Alianza Alemana", with an average population of 18 people and an age distribution of the occupants above 18 years. This building is located in the province of Chachapoyas, Amazonas in northern Peru. It is located at an altitude of 2483 meters above sea level, between the coordinates $6^{\circ} 13^{\prime} 00^{\prime \prime} \mathrm{S}$ and $77^{\circ} 51^{\prime} 00^{\prime \prime} \mathrm{O}$.

\subsection{Mixed system design}

The mixed treatment system for the purification of greywater has two parts, which are connected to each other. The first one is a grey water collection system, with a capacity of 100 litres, with the purpose of adequately feeding the filter systems of the following component. The second part has three mechanical filters, each with a capacity of 600 litres, and whose measurements are $100 \mathrm{~cm}$ in width per $100 \mathrm{~cm}$ in length and $60 \mathrm{~cm}$ in depth. Each filter's base is composed of three layers; the first layer has $0.24 \mathrm{~m} 3$ of 1 " river stone, the second one of 0.04 $\mathrm{m} 3$ of concrete, and the last one of $0.24 \mathrm{~m} 3$ of sand mixed with $0.06 \mathrm{~m} 3$ of coal generated from wood. Furthermore, in the third filter, we also included two bioremediation plants, duckweed (Lemma minor L) and watercress (Nasturtium officinale L), which were distributed in equal parts. It was taken an average height of 10 centimetres into account for the aforementioned plants, thus ensuring their proper development (Figure 1).

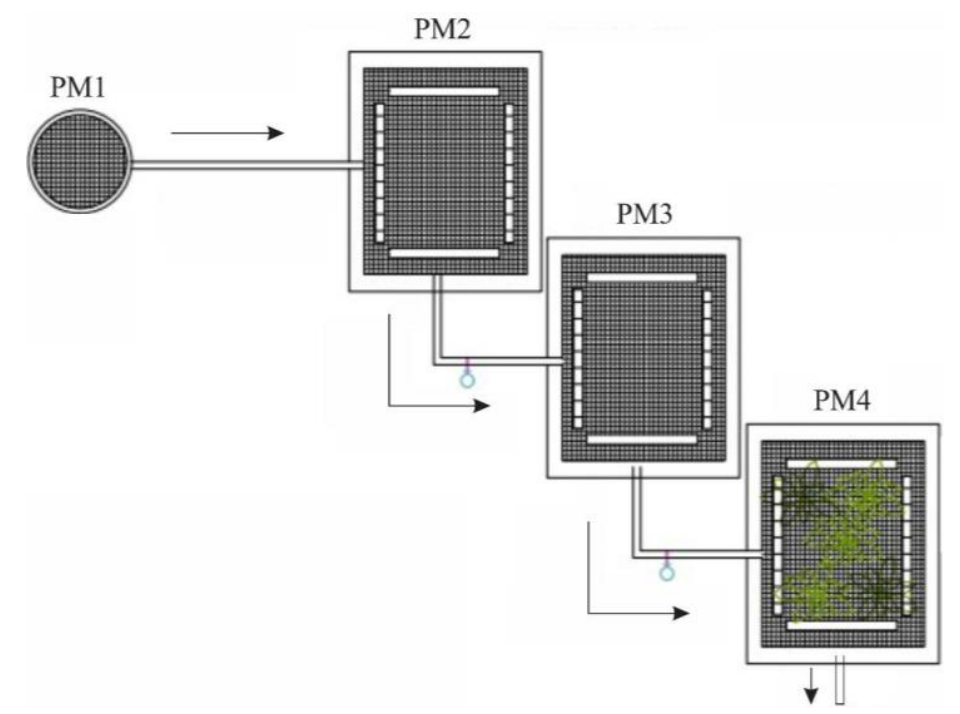

Figure 1. Design of the mixed treatment system based on filtration and bioremediation techniques (PM1: Collection, PM2: Filter 1, PM3: Filter 2, PM4: Filter 3)

\subsection{Methodology}

Sampling was carried out every 15 days between June and July 2018. For each established sampling point (PM1, PM2, PM3 and PM4) we collected four samples. The collection, storage, 
and transfer of samples, including laboratory analysis, were done according to APHA et al. (2017). Moreover, data collection of $\mathrm{pH}$ and Dissolved Oxygen (DO) was performed on-site using a Hanna Model HI 98194 multiparametric water test. The samples to determine biochemical oxygen demand $\left(\mathrm{BOD}_{5}\right)$ and chemical oxygen demand $(\mathrm{COD})$, parameters that establish the contamination of organic matter in water bodies, were collected in dark plastic containers and transparent plastic bottles, thereby allowing the physicochemical analysis of electrical conductivity (EC), total dissolved solids (TDS), total suspended solids (TSS), alkalinity and phosphates. Such analyses were performed at the Soil and Water Laboratory of the Research Institute for the Sustainable Development of the "Ceja de Selva" (INDES-CES) from the National University Toribio Rodriguez de Mendoza de Amazonas.

\subsection{Statistical analysis}

First of all, a graphic analysis of the box and whiskers of each parameter per sampling point was created to study the behaviour of the parameters in each part of the system. Likewise, a Kruskal-Walis analysis of each parameter was made and subsequently a post-hoc test, a Mann-Whitney test with the Bonferroni adjustment method, was carried out on the parameters that showed significant differences, in the interest of identifying the existence of differences between individual parts of the system, and thus being able to compare the behaviour and interrelationship at the inflow and outflow stages of the system. To understand the relationship between the studied parameters, a Spearman correlation analysis was performed. Finally, it was verified graphically whether all the parameters met the maximum permitted limits for $\mathrm{pH}, \mathrm{DO}$, EC, Alkalinity, BOD and COD, set by the Environmental Quality Standards (EQS) of Water for Category 3: irrigation water for vegetables and animal beverages, established by the Ministry of Environment, Peru (2017). Due to the fact that the parameters of TDS, TSS and phosphate are not included in the EQS, they were tested with standards established by the Food and Agriculture Organization of the United Nations (FAO) for water quality in agriculture (Ayers and Westcot, 1994). All statistical analyses were performed at a significance level of $\mathrm{p}<0.05$ with the statistical software R v. 3.6.3 (R Development Core Team, 2020).

\section{RESULTS AND DISCUSSION}

\subsection{Performance of the physicochemical parameters in the mixed treatment system}

We found that the parameters that showed a reduction throughout the treatment system are $\mathrm{pH}$ ranging from 9.56 to 7.50 , DO from $6.58 \mathrm{mg} / \mathrm{L}$ to $3.13 \mathrm{mg} / \mathrm{L}$, TSS from $1742.00 \mathrm{mg} / \mathrm{L}$ to $298.50 \mathrm{mg} / \mathrm{L}$, alkalinity from $106.06 \mathrm{mg} / \mathrm{L}$ to $76 \mathrm{mg} / \mathrm{L}$, phosphates from $1.12 \mathrm{mg} / \mathrm{L}$ to 0.31 $\mathrm{mg} / \mathrm{L}, \mathrm{BOD}$ from $28.13 \mathrm{mg} / \mathrm{L}$ to $12.31 \mathrm{mg} / \mathrm{L}$ and COD from $472.38 \mathrm{mg} / \mathrm{L}$ to $8.52 \mathrm{mg} / \mathrm{L}$. On the other hand, the parameters that experienced an increase are EC rising from $186.75 \mu \mathrm{S} / \mathrm{cm}$ to $328.25 \mu \mathrm{S} / \mathrm{cm}$ and TDS from $112.05 \mathrm{mg} / \mathrm{L}$ to $196.95 \mathrm{mg} / \mathrm{L}$ (Figure 2).

It should be noted that $\mathrm{pH}$ is one of the parameters which is most affected by the mixed treatment system, as it has been reduced from alkaline to almost neutral (Figure 2A). This performance can also be observed in fast, slow and mixed sand filters for obtaining drinking water (Laghari et al., 2018). In fact, this parameter has enormous importance in wastewater treatment, due to the high influence on biological, chemical or physical treatments (Aelterman et al., 2006; Issabayeva and Dih, 2019). As an example of this, it is relevant in the ammonium oxidation process (Tomaszewski et al., 2017), in advanced oxidation processes (Boczkaj and Fernandes, 2017), as well as in microbiological processes for the elimination of phosphorus (Stokholm-Bjerregaard et al., 2017).

Rev. Ambient. Água vol. 15 n. 6, e2599 - Taubaté 2020 

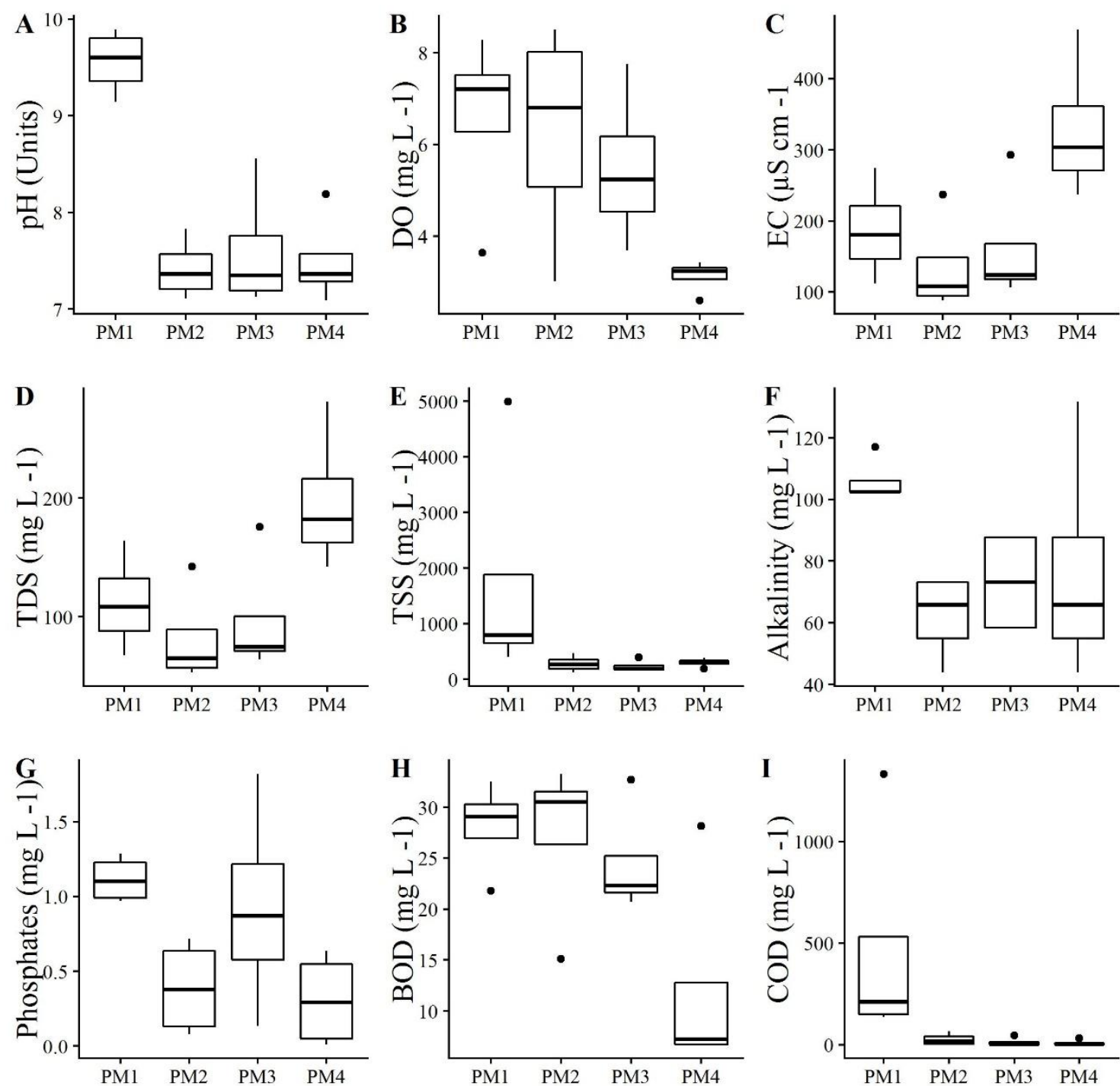

Figure 2. Average values of $\mathrm{pH}(\mathrm{A}), \mathrm{DO}(\mathrm{B}), \mathrm{EC}(\mathrm{C})$, TDS (D), TTS (E), Alkalinity (F), Phosphates $(\mathrm{G})$, BOD $(\mathrm{H}), \mathrm{COD}(\mathrm{I})$ at the different sampling points in the system.

In contrast, regarding DO, it was negatively affected since it had a significant decrease (Figure 2B). Usually this is typical at the bottom of oxidation ponds (Noikondee et al., 2019). However, DO reduction is very common in biological treatments, since oxygen consumption is an excellent indicator that the system works properly (Harja et al., 2016). Nevertheless, it would be ideal to include an additional method in this system to increase DO, given that it is essential to biodegrade contaminants, especially organic matter (Radzi et al., 2020).

In relation to EC and TDS parameters, which are directly related to each other, they experience an increase along the treatment system points (Figure $2 \mathrm{C}$ and 2D). These parameters usually decrease when biological treatments are applied (Duque-Sarango et al., 2018). This behavior is due to the dragging of particles in the system when the filters contain sand and carbon (Pompei et al., 2017). Nevertheless, just the opposite occurs with TSS (Figure 2E), owing to the fact that there are seasonal phases in the filter, and in the absence of pumps, sedimentation processes, therefore take place, leading to a settling of solid particles to the bottom (Merizalde et al., 2019).

The alkalinity decreased from Point PM1 to Point PM2 of the treatment; however, it was constant in the remaining points (Figure 2F). Alkalinity is an important parameter, not only because it varies according to the type of treatment and temperature, but also because it is an indicator for making $\mathrm{pH}$ adjustments in the systems, as it is strongly related to it, and thus 
prevents corrosion or incrustation in the treatment systems (Silva-Teira et al., 2018). The reduction of phosphate (Figure $2 \mathrm{G}$ ) is mainly due to assimilation by aquatic plants, since it is an important nutrient for their growth (Delgadillo-Mirquez et al., 2016).

The organic matter, BOD and COD parameters showed a large decrease throughout the mixed system (Figure $2 \mathrm{H}$ and 2I). The same inclinations are found in other water treatments, for instance, stabilization or oxidation ponds, which, by degrading organic matter and oxygenating it, have proven to be efficient, reducing up to $82 \%$ of organic matter (Peña et al., 2018). Similarly, it has been shown that aquatic plants are efficiently removing organic matter in the range of 70-86\% when using Eichhornia crassipes (Mart.) Solms, and about 58\% when using Lemma minor L, both of which are used in this research (Rodríguez-Miranda et al., 2010).

\subsection{Spatial dynamics for the mixed treatment system}

The Kruskal-Wallis analysis for the nine physicochemical parameters showed significant differences for $\mathrm{pH}$, TSS, Phosphates and COD (Table 1). After applying the post-hoc test (Mann-Whitney test), it was found that point number one of the systems differs from the rest of the treatment system

Table 1. Kruskal-Wallis analysis and post-hoc test (Mann-Whitney test) for the analyzed physicochemical parameters.

\begin{tabular}{|c|c|c|c|c|}
\hline \multirow{2}{*}{ Parameters } & \multicolumn{2}{|c|}{ Kruskal-Wallis } & \multicolumn{2}{|c|}{ Post-hoc } \\
\hline & $\chi^{2}$ & Sig. & Different PM & Same PM \\
\hline pH (Units) & 8.54 & $0.036^{*}$ & 1 & $3,4,2$ \\
\hline $\mathrm{DO}(\mathrm{mg} / \mathrm{L})$ & 6.77 & $0.079^{\mathrm{ns}}$ & \multicolumn{2}{|c|}{ Same } \\
\hline $\mathrm{EC}(\mu \mathrm{S} / \mathrm{cm})$ & 7.48 & $0.057^{\mathrm{ns}}$ & \multicolumn{2}{|c|}{ Same } \\
\hline TDS (mg/L) & 7.48 & $0.058^{\mathrm{ns}}$ & \multicolumn{2}{|c|}{ Same } \\
\hline TSS (mg/L) & 8.25 & $0.041 *$ & 1 & $3,4,2$ \\
\hline Alkalinity (mg/L) & 6.55 & $0.088^{\mathrm{ns}}$ & \multicolumn{2}{|c|}{ Same } \\
\hline Phosphates (mg/L) & 8.76 & $0.033 *$ & 1 & $2,4,3$ \\
\hline $\mathrm{BOD}_{5}(\mathrm{mg} / \mathrm{L})$ & 5.87 & $0.118^{\mathrm{ns}}$ & \multicolumn{2}{|c|}{ Same } \\
\hline $\mathrm{COD}(\mathrm{mg} / \mathrm{L})$ & 10.41 & $0.015^{*}$ & 1 & $2,3,4$ \\
\hline
\end{tabular}

*Significant $(\mathrm{P}<0.05),{ }^{\mathrm{ns}}$ not significant $(\mathrm{P}>0.05)$.

As for the $\mathrm{pH}$, TSS, phosphates and COD parameters, those parameters have been affected by the mixed treatment system (Table 1). Both $\mathrm{pH}$ and TSS are significantly affected by the action of mechanical filters, due to the retention of particles larger than $0.45 \mu \mathrm{m}$ (Laghari et al., 2018) and the effect of calcium carbonate that is usually found in the sand (Holtman et al., 2018). The significant effects on phosphates are due to the action of aquatic plants when using them as a nutrient (Delgadillo-Mirquez et al., 2016), whereas the effects on COD are mainly due to the path taken by the water through the various mechanical filters, which promotes oxygenation and thus the degradation of organic matter (Achak et al., 2019).

\subsection{Water quality testing of the mixed treatment system}

Regarding water warmth evolution, it is noted that at the beginning, all parameters meet the regulations, but $\mathrm{pH}$, TSS, BOD and COD. On the other hand, at the end of the treatment, the only parameters that fail to meet the regulations are the DO and the TSS (Figure 3).

If we compare the final values of $\mathrm{pH}, \mathrm{OD}, \mathrm{EC}$, Alkalinity, $\mathrm{BOD}$ and $\mathrm{COD}$ parameters with the Environmental Quality Standards (EQS) for Water, Category 3: irrigation water for vegetables and animal beverages, established by the Peruvian Ministry of the Environment (Peru, 2017), we find that they all meet the standard, except for the DO. TDS, TSS and 
phosphate parameters were compared with the standards established by the FAO, for water quality in agriculture, given that Peruvian regulations do not include them within the RCTs (Figure 3). Although $\mathrm{pH}$ is not widely used to assess irrigation water quality, it is important to establish the relative concentrations of dissolved carbonate species, which affect plant nutrient uptake (Jaramillo and Restrepo, 2017).
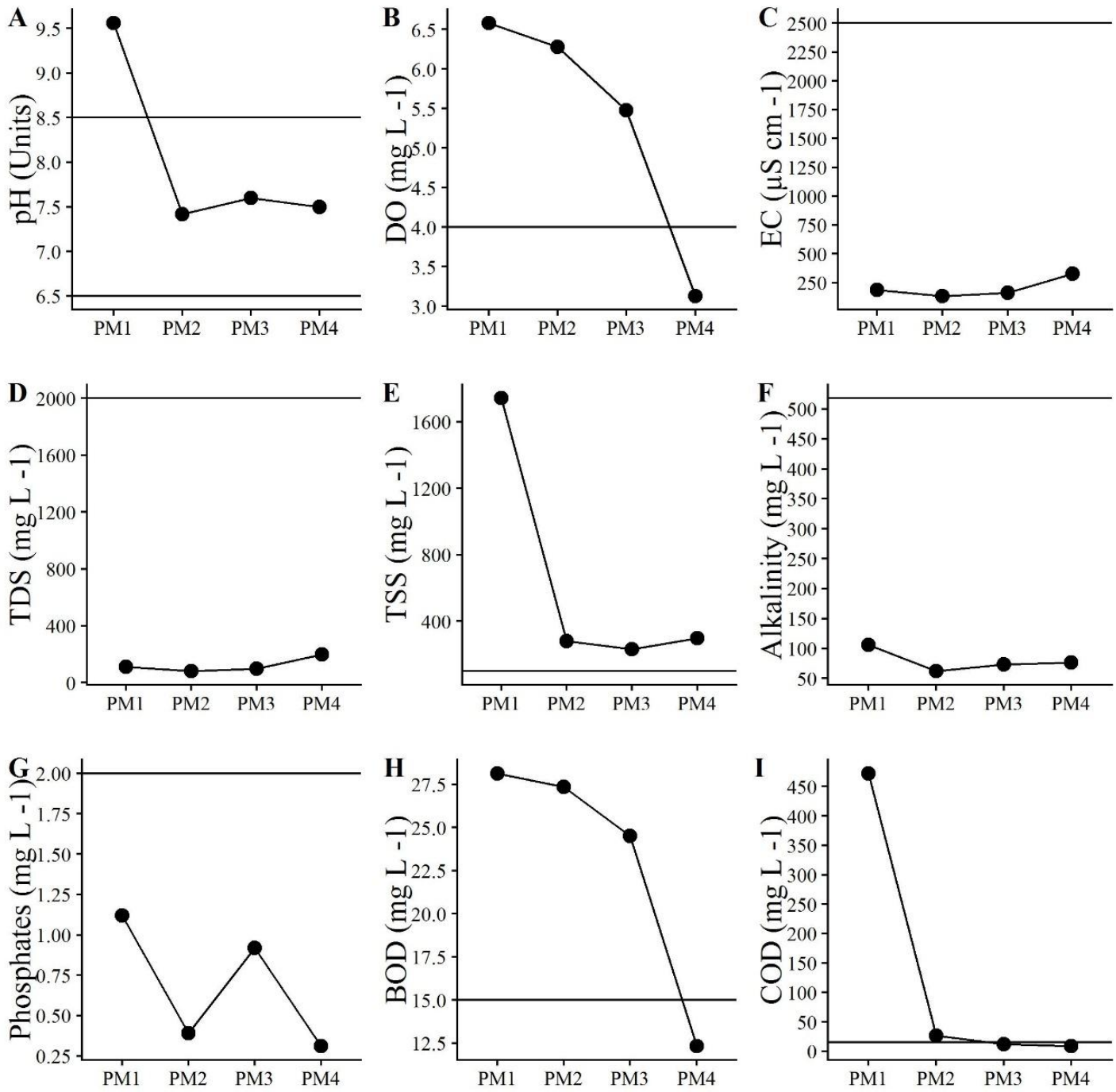

Figure 3. Comparison of average values of $\mathrm{pH}(\mathrm{A})$, DO (B), EC (C), TDS (D), TTS (E), Alkalinity (F), Phosphates (G), BOD (H), COD (I) regulations.

Parameters which are of primary importance for irrigation include phosphates and organic matter (BOD and COD), due to their strong influence on plant growth (Da Silva Gomes et al., 2019). Nevertheless, low DO concentration has a major disadvantage, since values found to be lower than $3.0 \mathrm{mg} / \mathrm{L}$ make biota survival impossible (Rubio Arias et al., 2014). Therefore, one option may be the implementation of air pumps, in order for the DO values to be increased. Both TDS and phosphates meet the limits established by the FAO. However, TSS exceeds the maximum limit allowed. Nevertheless, that limit is only for drip irrigation to avoid clogging (Ayers and Westcot, 1994). This means that we can use them for direct irrigation.

\section{CONCLUSIONS}

Our results demonstrated that the mixed treatment system improved greywater quality for irrigation uses, notably by reducing levels of $\mathrm{pH}$, TSS, phosphates, BOD and COD. As a result, 
these parameters were favourably influenced in each system filter. Nevertheless, the EC and TDS parameters were negatively affected by the sediment carry-over in the treatment system, as well as the DO reaching lower values for the development of biota.

Finally, all final values of parameters meet the FEA and FAO standards for irrigation water, except the DO. Therefore, we suggest implementing an aeration system within the treatment.

\section{REFERENCES}

ABELLÁN, J. Water supply and sanitation services in modern Europe: developments in 19th 20th centuries. In: INTERNATIONAL CONGRESS OF THE SPANISH ASSOCIATION OF ECONOMIC HISTORY, 12., 6-9 Sep. 2017, Salacamca. Proceedings[...] Salamanca: University of Salamanca, 2017.

ACHAK, M.; BOUMYA, W.; OUAZZANI, N.; MANDI, L. Preliminary evaluation of constructed wetlands for nutrients removal from olive mill wastewater (OMW) after passing through a sand filter. Ecological Engineering, v. 136, p. 141-151, 2019. https://doi.org/10.1016/j.ecoleng.2019.06.007

AELTERMAN, P.; RABAEY, K.; CLAUWAERT, P.; VERSTRAETE, W. Microbial fuel cells for wastewater treatment. Water Science and Technology, v. 54, n. 8, p. 9-15, 2006. https://doi.org/10.2166/wst.2006.702

APHA; AWWA; WEF. Standard Methods for the examination of water and wastewater. 23nd ed. Washington, 2017. 1504 p.

AYERS, R. S.; WESTCOT, D. W. Water quality for agriculture. Roma: FAO, 1994. 85 p.

AZUBUIKE, C. C.; CHIKERE, C. B.; OKPOKWASILI, G. C. Bioremediation techniquesclassification based on site of application: principles, advantages, limitations and prospects. World Journal of Microbiology and Biotechnology, v. 32, n. 11, p. 1-18, 2016. https://doi.org/10.1007/s11274-016-2137-x

BOCZKAJ, G.; FERNANDES, A. Wastewater treatment by means of advanced oxidation processes at basic pH conditions: A review. Chemical Engineering Journal, v. 320, p. 608-633, 2017. https://doi.org/10.1016/j.cej.2017.03.084

BWAPWA, J. K. Review on Main Issues Causing Deterioration of Water Quality and Water Scarcity: Case Study of South Africa. Environmental Management and Sustainable Development, v. 7, n. 3, p. 14-34, 2018. https://doi.org/10.5296/emsd.v7i3.13156

CAI, Y.; YUE, W.; XU, L.; YANG, Z.; RONG, Q. Sustainable urban water resources management considering life-cycle environmental impacts of water utilization under uncertainty. Resources, Conservation and Recycling, v. 108, p. 21-40, 2016. https://doi.org/10.1016/j.resconrec.2016.01.008

CALZADA, J.; IRANZO, S.; SANZ, A. Community-Managed Water Services: The Case of Peru. Journal of Environment and Development, v. 26, n. 4, p. 400-428, 2017. https://doi.org/10.1177/1070496517734020

DA SILVA GOMES, J. W.; DA SILVA DIAS, N.; MORENO PIZANI, M. A. Growth and mineral composition of the melon with different doses of phosphorus and organic matter. Dyna, v. 86, n. 211, p. 363-368, 2019. https://doi.org/10.15446/dyna.v86n211.69776 
DELGADILLO-MIRQUEZ, L.; LOPES, F.; TAIDI, B.; PAREAU, D. Nitrogen and phosphate removal from wastewater with a mixed microalgae and bacteria culture. Biotechnology Reports, v. 11, p. 18-26, 2016. https://doi.org/10.1016/j.btre.2016.04.003

DUQUE-SARANGO, P.; HERAS-NARANJO, C.; LOJANO-CRIOLLO, D. Modelamiento del tratamiento biológico de aguas residuales; estudio en planta piloto de contactores biológicos rotatorios. Revista Ciencia UNEMI, v. 11, p. 88-96, 2018.

FERRO-MAYHUA, F.; FERRÓ-GONZALES, P. F.; FERRÓ-GONZALES, A. L. Distribución temporal de las enfermedades diarreicas agudas, su relación con la temperatura y cloro residual del agua potable en la ciudad de Puno, Perú. Journal of High Andean Research, v. 21, n. 1, p. 69-80, 2019. https://doi.org/10.18271/ria.2019.446

FOWDAR, H. S.; HATT, B. E.; BREEN, P.; COOK, P. L. M.; DELETIC, A. Designing living walls for greywater treatment. Water Research, v. 110, p. 218-232, 2017. https://doi.org/10.1016/j.watres.2016.12.018

GHERNAOUT, D.; BADIS, A.; BRAIKIA, G.; MATÂAM, N.; FEKHAR, M.; GHERNAOUT, B.; BOUCHERIT, A. Enhanced coagulation for algae removal in a typical Algeria water treatment plant. Environmental Engineering and Management Journal, v. 16, n. 10, p. 2303-2315, 2017. https://doi.org/10.30638/eemj.2017.238

GUTIERREZ-ESPINO, C.; ROMERO-CÓNDOR, E. Perú: Formas de acceso a agua y sanemiento básico. Lima: INEI, 2018.

GUZMÁN, B. L.; NAVA, G.; BEVILACQUA, P. D. Vigilancia de la calidad del agua para consumo humano en Colombia: desafíos para la salud ambiental. Revista Facultad Nacional de Salud Pública, v. 34, n. 2, p. 175-183, 2016. https://doi.org/10.17533/udea.rfnsp.v34n2a06

HARJA, G.; NASCU, I.; MURESAN, C.; NASCU, I. Improvements in dissolved oxygen control of an activated sludge wastewater treatment process. Circuits, Systems, and Signal Processing, v. 35, n. 6, p. 2259-2281, 2016. https://doi.org/10.1007/s00034016-0282-y

HOLTMAN, G. A.; HALDENWANG, R.; WELZ, P. J. Biological sand filter system treating winery effluent for effective reduction in organic load and $\mathrm{pH}$ neutralisation. Journal of Water Process Engineering, v. 25, p. 118-127, 2018. https://doi.org/10.1016/j.jwpe.2018.07.008

ISSABAYEVA, G.; DIH, J. C. M. Rubber industry wastewater treatment: Adsorption of zinc. AIP Conference Proceedings, v. 2157, 2019. https://doi.org/10.1063/1.5126547

JARAMILLO, M. F.; RESTREPO, I. Wastewater reuse in agriculture: A review about its limitations and benefits. Sustainability (Switzerland), v. 9, n. 10, 2017. https://doi.org/10.3390/su9101734

LAGHARI, A. N.; WALASAI, G. D.; JATOI, A. R.; SHAIKH, F. A.; SIYAL, Z. A. Performance analysis of water filtration units for reduction of $\mathrm{pH}$, Turbidity, Solids and Electricity Conductivity. Engineering, Technology \& Applied Science Research, v. 8, n. 4, p. 3209-3212, 2018.

MERIZALDE, E.; MONTENEGRO, L.; CABRERA, M. Estudio de un Sistema de Tratamiento de Aguas Residuales Provenientes de una Industria de Papel. Revista Politécnica, v. 43, n. 1, p. 07-14, 2019. https://doi.org/10.33333/rp.vol43n1.951 
NOIKONDEE, R.; CHUNKAO, K.; BUALERT, S.; PATTAMAPITOON, T. Evaluation of dissolved oxygen stratification in an oxidation pond for community wastewater treatment through King's Royally initiated "Nature by Nature" process. Environment Asia, v. 12, n. 1, p. 169-177, 2019. https://doi.org/10.14456/ea.2019.19

PEÑA, S.; MAYORGA, J.; MONTOYA, R. Propuesta de tratamiento de las aguas residuales de la ciudad de Yaguachi (Ecuador). Revista Ciencia e Ingeniería, v. 39, n. 2, p. 161 $168,2018$.

PÉREZ-DÍAZ, J. P.; ORTEGA-ESCOBAR, H. M.; RAMÍREZ-AYALA, C.; FLORESMAGDALENO, H.; SÁNCHEZ-BERNAL, E. I.; CAN-CHULIM, Á.; MANCILLAVILLA, O. R. Concentración de nitrato, fosfato, boro y cloruro en el agua del río Lerma. Ecosistemas y Recursos Agropecuarios, v. 6, n. 16, p. 175, 2019. https://doi.org/10.19136/era.a6n16.1829

PERU. Ministerio del Ambiente. Decreto Supremo $\mathrm{n}^{\circ}$ 004-2017-MINAM. Aprueban Estándares de Calidad Ambiental para agua y establecen disposiciones complementarias. El Peruano, Lima, 07 de jun. de 2017.

POIRIER, L.; PINAULT, L.; ARMSTRONG, N.; GHIGO, E.; DAUDÉ, D.; CHABRIÈRE, E. Evaluation of a robust engineered enzyme towards organophosphorus insecticide bioremediation using planarians as biosensors. Chemico-Biological Interactions, v. 306, p. 96-103, 2019. https://doi.org/10.1016/j.cbi.2019.04.013

POMPEI, C. M. E.; CIRIC, L.; CANALES, M.; KARU, K.; VIEIRA, E. M.; CAMPOS, L. C. Influence of PPCPs on the performance of intermittently operated slow sand filters for household water purification. Science of the Total Environment, v. 581-582, p. 174185, 2017. https://doi.org/10.1016/j.scitotenv.2016.12.091

$\mathrm{R}$ DEVELOPMENT CORE TEAM. $\mathbf{R}$ a language and environment for statistical computing. Vienna: R Foundation for Statistical Computing, 2020.

RADZI, E. Z.; WAHAB, M. S.; SAHDAN, M. Z.; HAMDAN, R.; ZAKARIAH, R. A. Gravitational aeration tower filter system to increase the dissolved oxygen amount for iron removal in groundwater. International Journal of Integrated Engineering, v. 12, n. 3, p. 207-215, 2020. https://doi.org/10.30880/ijie.2020.12.03.024

REYES FARJE, J. F.; MORALES ROJAS, E. Eficiencia del tratamiento de aguas residuales utilizando lombrices californianas (Eisenia foétida) y el jacinto acuático (Eichhornia crassipes), Chachapoyas, 2018. Revista de Investigación Científica UNTRM: Ciencias Naturales e Ingeniería, v. 2, n. 1, p. 33-36, 2019. http://dx.doi.org/10.25127/ucni.v2i1.445

RODRÍGUEZ-MIRANDA, J. P.; GÓMEZ, E.; GARAVITO, L.; LÓPEZ, F. Estudio de comparación del tratamiento de aguas residuales domésticas utilizando lentejas y buchón de agua en humedales artificiales. Tecnología y Ciencias del Agua, v. 1, n. 1, p. 59-68, 2010.

RUBIO ARIAS, H. O.; ORTIZ DELGADO, R. C.; QUINTANA MARTÍNEZ, R. M.; SAUCEDO TERÁN, R. A.; OCHOA RIBEIRO, J. M.; REY BURCIAGA, N. I. Índice De Calidad De Agua (ICA) en la presa La Boquilla en Chihuahua, México. Ecosistemas y Recursos Agropecuarios, v. 1, n. 2, p. 139-150, 2014. 
SILVA-TEIRA, A.; VÁZQUEZ-PADÍN, J. R.; WEILER, R.; FERNÁNDEZ-GONZÁLEZ, R.; ROGALLA, F.; GARRIDO, J. M. Performance of a hybrid membrane bioreactor treating a low strength and alkalinity wastewater. Process Biochemistry, v. 66, n. September 2017, p. 176-182, 2018. https://doi.org/10.1016/j.procbio.2017.12.015

STOKHOLM-BJERREGAARD, M.; MCILROY, S. J.; NIERYCHLO, M.; KARST, S. M.; ALBERTSEN, M.; NIELSEN, P. H. A critical assessment of the microorganisms proposed to be important to enhanced biological phosphorus removal in full-scale wastewater treatment systems. Frontiers in Microbiology, v. 8, p. 1-18, 2017. https://doi.org/10.3389/fmicb.2017.00718

TOMASZEWSKI, M.; CEMA, G.; ZIEMBIŃSKA-BUCZYŃSKA, A. Influence of temperature and $\mathrm{pH}$ on the anammox process: A review and meta-analysis. $\begin{array}{lllll}\text { Chemosphere, } & \text { v. } & 182, & \text { p. } & 203-214,\end{array}$ https://doi.org/10.1016/j.chemosphere.2017.05.003 


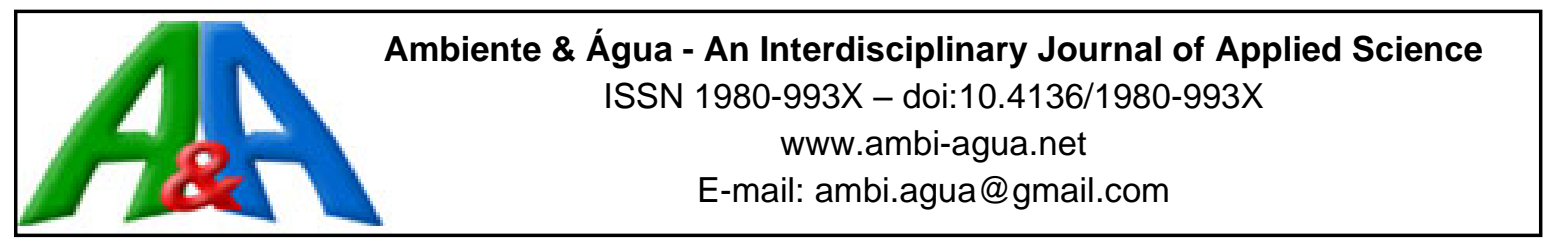

\title{
Polymer coating in soybean seed treatment and their relation to leaching of chemicals
}

\author{
ARTICLES doi:10.4136/ambi-agua.2602
}

Received: 18 Jun. 2020; Accepted: 28 Sep. 2020

\begin{abstract}
Eduardo José Ludwig $^{1 *(D)}$; Ubirajara Russi Nunes1 ${ }^{1}$; Osmar Damian Prestes ${ }^{2}{ }^{(D}$; Lovane Klein Fagundes ${ }^{1}$; ; Tiéle Stuker Fernandes ${ }^{1}{ }^{(D}$; Nathália Saibt ${ }^{2}[\mathbb{i}$

${ }^{1}$ Departamento de Fitotecnia. Universidade Federal de Santa Maria (UFSM), Avenida Roraima, nº 1000, CEP: 97105-970, Santa Maria, RS, Brazil. E-mail: russinunes@yahoo.com.br, lovklein@yahoo.com.br, tielefernandes@hotmail.com

${ }^{2}$ Departamento de Química. Universidade Federal de Santa Maria (UFSM), Avenida Roraima, no 1000 , CEP: 97105-970, Santa Maria, RS, Brazil. E-mail: osmar.prestes@ufsm.br, nattiesaibt@hotmail.com *Corresponding author. E-mail: eduludwig@yahoo.com.br
\end{abstract}

\begin{abstract}
This study evaluated the physiological quality and quantified the efficiency of polymer in reducing the loss of phytosanitary products by leaching from soybean seeds of different diameters and in different treatments. Two lots of seed and two types of treatments were tested: polymers associated with seed treatment, and polymer application in layers after the seed treatment. For that, the following treatments were analyzed: Control= no seed treatment; Treat + pol $=$ seed treatment + polymers in the mix; Treat/pol $=$ seed treatment + polymers applied in layers; Treat $=$ seed treatment. To evaluate seed treatment retention by the polymers, extraction equipment was employed and leaching of the active ingredient thiamethoxam was quantified. Evaluation of physical quality was conducted with tests of germination rate, first count, emergence rate, accelerated aging, seedling length, seedling dry mass and moisture content. Polymer application associated with seed treatment was efficient in reducing losses by leaching, reducing product loss by $20 \%$. No significant differences in retention and physiological quality were found when different methods for polymer application were compared. Bigger seeds presented greater vigor, but the germination rate was unaffected.
\end{abstract}

Keywords: film coating, Glycine $\max$ (L.) Merrill, layer treatment.

\section{Polímeros no tratamento de sementes de soja e sua relação com a lixiviação de produtos químicos}

\section{RESUMO}

O objetivo deste trabalho foi avaliar a qualidade fisiológica e quantificar a eficácia do polímero na retenção de perdas por lixiviação do tratamento fitossanitário em sementes de soja com diferentes diâmetros e tratadas sob diferentes formas. Foram utilizados dois lotes de sementes com diferentes diâmetros e foram realizadas duas formas de aplicação do tratamento: polímero associados ao tratamento fitossanitário na mesma calda e aplicação do polímero em camada após o tratamento, sendo os tratamentos formados da seguinte maneira: Control= sem tratamento, Treat + pol $=$ Tratamento fitossanitário + polímero aplicados na mesma calda, Treat/pol $=$ Tratamento fitossanitário + polímero aplicados em camadas, Treat $=$ Tratamento 
fitossanitário. Para avaliação da retenção do tratamento pelo polímero foi utilizado um extrator e realizada a quantificação do ingrediente ativo tiametoxam lixiviado. Para avaliação da qualidade fisiológica foram realizados os testes de germinação, primeira contagem, emergência, envelhecimento acelerado, comprimento de plântulas, massa seca de plântulas e grau de umidade. A aplicação de polímero associado ao tratamento fitossanitário de sementes foi eficiente na diminuição das perdas por lixiviação, reduzindo em $20 \%$ a perda de produtos. Não houve diferença na capacidade de retenção e na qualidade fisiológica entre as diferentes formas de aplicação do polímero. Sementes de maior tamanho apresentam maior vigor, porém a germinação não é afetada.

Palavras-chave: Glycine max (L.) Merrill, tratamento em camadas, peliculização.

\section{INTRODUCTION}

The establishment of soybean seedling in the field is a critical step for achieving success in the following growth phases of the crop. However, there are several factors that can hinder the development of the seedling stand. Pests and pathogen attacks can be considered major causes of reduced germination, and consequently, lower physiological quality of seeds (Zhang et al., 2016; Hesler et al., 2018).

Seed treatment aims to protect seeds against these diverse factors. By providing adequate conditions for the establishment of seedlings and benefiting the following growth phases, the procedure maintains the physiological and sanitary quality of seeds (Arfaoui et al., 2018). The methods generally consist of applying chemicals that protect seeds against adverse effects. Thus, attacks during the seedling's establishment are controlled, and crop emergence and development are stimulated (Balardin et al., 2011).

Among the current challenges in seed treatment are the development of lower doses, more effective and less pollutant active ingredients, and improving the adherence of chemicals (Lima et al., 2006). Detected problems in seed treatment include the formation of toxic dust and loss of chemical due to leaching. In regard to the latter problem, the use of chemicals in agriculture possess risks of groundwater contamination (Castro et al., 2008).

Polymers can be applied in association with fungicides and insecticides for seed treatment. Seed film coating is a method in which seeds are covered with polymers that increase the adherence of chemicals, thereby reducing risks of environmental contamination, formation of dust, attacks by fungi and moisture absorption during storage (Accinelli et al., 2016; Avelar et al., 2012; Vijaya Mahantesh et al., 2017). Ioannou et al. (2020) argue that polymers have been used as seed coatings, allowing the encapsulation and controlled release of pesticides used against pathogens, pests and insects that may interfere with seed germination. Using polymers for seed coating was found to benefit corn (Avelar et al., 2012) and rice (Fagundes et al., 2017).

The recent increases in the use of industrial seed treatment, which involves innovative equipment, and techniques such as the formulation of mixes containing fungicides, insecticides and nematicides can maximize the efficiency of the products, protect operators and reduce environmental contamination (Brzezinski et al., 2015). There is also equipment that allows the application of separate mixes during the seed treatment, thereby creating layers of chemicals.

Few studies investigated the relation between seed size and treatment, since the latter is commonly done considering the mass of seeds rather than their superficial area. Considering that a certain mass constituted by smaller seeds will present a larger superficial area than an equal mass of bigger seeds, the seed size can influence the efficiency of seed coating. Furthermore, seed size can possibly affect the physiological quality. A previous study reports the influence of seed size on the physiological quality, in which larger seeds presented higher physiological quality (Pádua et al., 2010). Contrarily, other authors suggest that these two 
characters are unrelated (Camozzato et al., 2009). According to Carvalho and Nakagawa (2012), seed size has no influence on germination, but affects seedling vigor. These authors reported that larger seeds originated more vigorous seedlings and might result in superior stands in fields with variable conditions. An advantage of smaller seeds is the larger ratio of surface area to volume which facilitates the absorption of water necessary for germination in soil (Kopper et al., 2010).

Studies on the relation between seed treatment and seed size are incipient. Therefore, the present work evaluated physiological quality and quantified the efficiency of a polymer in retaining chemicals on soybean seeds of different diameters and treated by different methods.

\section{MATERIAL AND METHODS}

The experiment was conducted in the Seeds Didactics and Research Laboratory and Pesticide Waste Analysis Laboratory, both of the Universidade Federal de Santa Maria.

Two seed lots from cultivar Nidera NA5909 were tested. The lots were collected in the field and their differentiation was based on sieve diameter. Therefore, seed retained in 5.5 to $6.0 \mathrm{~mm}$ sieves composed the $5.5 \mathrm{~mm}$ lot, whereas seeds retained in the $6.5-7.0 \mathrm{~mm}$ sieves composed the $6.0 \mathrm{~mm}$ lot.

Prior to seed treatment, the physiological quality of the seed lots were evaluated using tests of germination, first count, 1,000-seed weight and moisture content, according to the methodology described in Brazil (2009).

The chemical applied in the seed treatment was Avicta Completo® $\left(85 \mathrm{~g} \mathrm{~L}^{-1}\right.$ Abamectin + $115 \mathrm{~g} \mathrm{~L}^{-1}$ Thiamethoxam $+4 \mathrm{~g} \mathrm{~L}^{-1}$ Fludioxonil) at a dose of $6 \mathrm{~mL} \mathrm{~kg}^{-1}$ of seeds. The polymer Likoseed Vermelho® was applied in a dose of $1 \mathrm{~mL} \mathrm{~kg}^{-1}$ of seeds. The products were applied using two methods: polymers in association with seed treatment in the same mix; and polymer applied in a different mix after the seed treatment, which resulted in a layer treatment. Therefore, the following treatments were established: Control= no seed treatment; Treat+pol= seed treatment + polymer in the same mix; Treat/pol $=$ seed treatment + polymer applied in layers; Treat $=$ seed treatment.

In the treatments Treat+pol, the chemical and polymer were added in a unique mix used for seed treatment. Similarly, the treatment Treat involved a unique mix with the chemical. Otherwise, treatment Treat/pol involved separate applications of the seed treatment mix followed by the polymer mix. The later mix was applied after a homogenization step and included water in a concentration of $5 \mathrm{~mL} \mathrm{~kg}^{-1}$ of seed to form the required minimum volume of $6 \mathrm{~mL} \mathrm{~kg}^{-1}$. This polymer and water mix did not exceed the maximum volume of $14 \mathrm{~mL} \mathrm{~kg}^{-1}$, which results in no negative effect on physiological quality of seeds (Segalin et al., 2013).

The seed treatments were conducted in the center for seed treatment of COTRIBÁ, RS, BRAZIL. A model Momesso Arktos Africa batch treating machine was used for applying the mixes of treatments Treat+pol and Treat; and the two distinct mixes for treatment Treat/pol.

The extraction equipment used for measuring the leaching of chemicals from treated seeds was made of PVC pipes $(15 \mathrm{~cm}$ height and diameter of $4.6 \mathrm{~cm}$ ) placed side by side on a wooden support (Figure 1). A paper filter tied to the tubes was employed for covering the inferior part, as described by Fagundes et al. (2017). Furthermore, the equipment was filled with $7 \mathrm{~cm}$ of washed, sieved and sterilized sand. Five seeds from each of the four tested treatments were placed in the tubes and covered by $3 \mathrm{~cm}$ of the sand. Thus, the equipment simulated a $10 \mathrm{~cm}$ layer of soil in which seeds were sown at a $3 \mathrm{~cm}$ depth.

Simulated rainfall of $50 \mathrm{~mm}$ was applied for $20 \mathrm{~min}$ on the sand substrate that contained the seeds and was already saturated at $100 \%$ of water-holding capacity. The leached solution was collected in glass flasks placed under the tubes and taken for analyses at the LARP. Presence of the active ingredient Thiamethoxam in the samples was detected employing Ultra- 
High Performance Liquid Chromatography-tandem Mass Spectrometry (UHPLC-MS/MS) analyses, as described by Kemmerich et al. (2014).

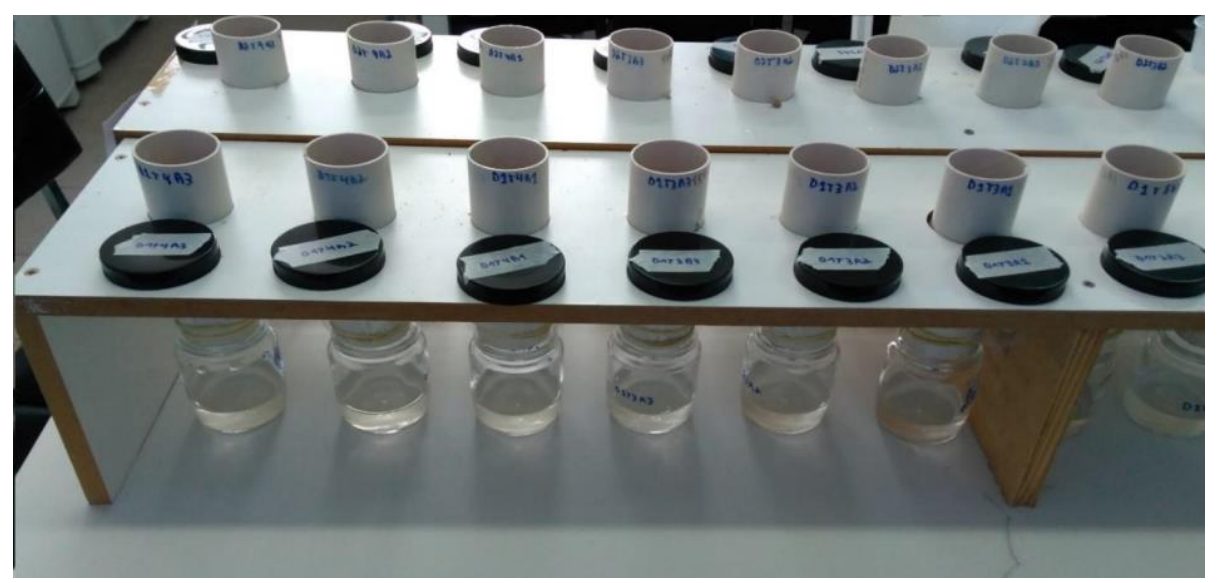

Figure 1. Extractor used for the simulated precipitation experiment and collection of leachate material.

Physiological quality of seeds with different diameters and treated with polymers in different methods were evaluated by the following tests:

Germination tests: performed according to the Rules for Seed Analyses (Brasil, 2009). Four repetitions of 50 seeds were sown on germitest paper rolls moistened with a water volume of 2.5 times the rolls' dry weight. The water used to hydrate the rolls had a $\mathrm{pH}$ of 5.8. These rolls were placed in a germinator at $25^{\circ} \mathrm{C}$ for eight days with constant light. Measurements were conducted afterwards and expressed as percentages of normal seedlings.

First count of the germination test: performed jointly with the germination test by computing the mean value of normal seedlings after five days of the sowing. Results were expressed as the percentage of normal seedlings.

Field emergence: four repetitions of 50 seeds from each treatment were sown at depth of $0.02 \mathrm{~m}$ in lines $1.0 \mathrm{~m}$ wide and spaced $0.20 \mathrm{~m}$ apart from each other. The percentage of seedlings emergence was evaluated 14 days after the sowing.

Accelerated aging: performed using the gerbox method with $40 \mathrm{~mL}$ of distilled water at $41^{\circ} \mathrm{C}$ for 48 hours. After that period, four repetitions of 50 seeds from each treatment were evaluated with the germination test. The counting was performed five days after the sowing.

Seedling length: four repetitions of 20 seeds from each treatment were sown in three lines on the superior part of germitest paper rolls. The rolls were placed in plastic bags and placed in a B.O.D incubator at $25^{\circ} \mathrm{C}$. Radicle and hypocotyl lengths of 10 randomly selected seedlings were measured using a millimeter ruler and the results were expressed in $\mathrm{cm}$ per seedling.

Radicle dry mass: after evaluating the seedling lengths, cotyledons were removed and the seedlings were placed in paper bags. After a 48 hours incubation period inside a germinator at $65 \pm 2^{\circ} \mathrm{C}$, the bags were weighted using a precision scale $(0.001 \mathrm{~g})$. The obtained masses were divided by the number of normal seedlings and the results were expressed in milligrams per seedling (mg seedling $\left.{ }^{-1}\right)$

Moisture content: determined using the laboratory stove method at $105^{\circ} \mathrm{C} \pm 3^{\circ} \mathrm{C}$ for 24 hours. Two repetitions containing $5 \pm 0.5 \mathrm{~g}$ of seed for each experimental unit were tested (Brasil, 2009)

The experiment had a completely randomized design in $2 \times 4$ factorial arrangement (seed lots $x$ seed treatment). For data analyses, variance analysis and comparison of means using the Scott-Knott test at the 5\% significance level in the statistical software Sisvar were calculated. Variables represented as percentages were transformed using $\arcsin \sqrt{\mathrm{x} / 100}$. 


\section{RESULTS AND DISCUSSION}

Initial evaluation of the two seed lots indicated that they did not present significant differences of physiological quality (Table 1). Nonetheless, the weight of 1,000 seeds differed between them due to the difference in size of the seeds.

Table 1. Average weight of 1,000 seeds (AW), first count (FC) and germination rate (G) from two soybean seed lots of the cultivar Nidera NA 5909.

\begin{tabular}{cccc}
\hline Diameter & AW $(\mathrm{g})$ & $\mathrm{FC}(\%)$ & $\mathrm{G}(\%)$ \\
\hline 5.5 & $146.3 \mathrm{a} *$ & $78 \mathrm{a}$ & $88 \mathrm{a}$ \\
6.5 & $181.2 \mathrm{~b}$ & $76 \mathrm{a}$ & $84 \mathrm{a}$ \\
\hline $\mathrm{CV}(\%)$ & 0.86 & 3.35 & 6.65 \\
\hline
\end{tabular}

* Different letters in the columns indicate means with statistically significant difference by the Scott-Knott test at the 5\% significance level.

For estimating the amount of active ingredient on the seeds (Table 2), a calculation was done using the concentration of the active ingredient in the commercial product and in the mix applied on the seeds, and the weight of 1,000 seeds from the two loots.

Table 2. Measured mass (mg) before and after leaching and percentage of the leached active ingredient (A.I.) Thiamethoxam $(\%)$ from five soybean seeds of the cultivar Nidera NA 5909. Seeds presented two distinct diameters, and underwent phytosanitary and polymers treatments and simulated rainfall.

\begin{tabular}{cccc}
\hline \multirow{2}{*}{ Diameter } & Initial A.I. & \multicolumn{2}{c}{ Leached A.I. } \\
\cline { 2 - 4 } & $\mathrm{Mg}$ & $\mathrm{Mg}$ & $\%$ \\
\hline 5,5 & 0,512 & $0,274 \mathrm{a}^{*}$ & $53,64 \mathrm{a}$ \\
6,5 & 0,634 & $0,342 \mathrm{~b}$ & $53,97 \mathrm{a}$ \\
\hline $\mathrm{CV}(\%)$ & - & 17,43 & 16,74 \\
\hline
\end{tabular}

* Different letters in the columns indicate means with statistically significant differences in the Scott-Knott test at the 5\% significance level. ${ }^{\text {ns: }}$ non-significant in the $\mathrm{F}$ test at $5 \%$ probability.

In the evaluation of chemicals leached, the results indicated a significant difference in the amount of the active ingredient thiamethoxam leached from seeds with different diameters, with more leaching detected from the larger seeds. This is due to the different weight of 1,000 seeds from the two lots. Larger seeds will have a smaller number of seeds per kilogram and consequently, smaller specific surface area. This difference was not observed when the comparison involved the percentage of leachate and the total active ingredient present. This is due to the fact that the guidelines for soybean seed treatment consider the mass rather than the number of seeds.

To become efficient, a sufficient quantity of chemicals needs to be applied and they must present a uniform distribution on the seeds. Thus, there is a need for correct technical information, and companies in the seed treatment market must investigate the factor seed size and give specific recommendations that aim for more efficient seed treatments. 
A significant difference in the factor seed treatment (Table 3) was found when seeds treated with polymer were compared to those only treated with the chemical. No significant difference was found when the different methods for applying the polymer were compared.

Table 3. Measured mass (mg) before and after leaching and percentage of leached active ingredient (A.I.) Thiamethoxam (\%) from five soybean seeds of the cultivar Nidera NA 5909, which underwent different phytosanitary and polymers treatments.

\begin{tabular}{cccc}
\hline \multirow{2}{*}{ Treatment } & \multicolumn{2}{c}{ Initial A.I. } & \multicolumn{2}{c}{ Leached A.I. } \\
\cline { 2 - 4 } & $\mathrm{Mg}$ & $\mathrm{mg}$ & $\%$ \\
\hline Control & 0 & $0 \mathrm{nd}^{*}$ & $0 \mathrm{nd}$ \\
Treat+pol & 0.574 & $0.268 \mathrm{a}^{1}$ & $46.67 \mathrm{a}$ \\
Treat/pol & 0.574 & $0.271 \mathrm{a}$ & $47.19 \mathrm{a}$ \\
Treat & 0.574 & $0.386 \mathrm{~b}$ & $67.56 \mathrm{~b}$ \\
\hline CV $(\%)$ & & 17.43 & 16.74 \\
\hline
\end{tabular}

*not detected by the used method. ${ }^{1}$ Different letters in the columns indicate means with statistically significant differences in the Scott-Knott test at the 5\% significance level.

The present results show that the use of polymers in both seed and layer treatment mixes was efficient in reducing the loss of the active ingredient Thiamethoxam by leaching in the simulated rainfall test. This result corroborates studies on corn by Avelar et al. (2012) and rice by Fagundes et al. (2017), who achieved reduced losses by leaching from the sand column and reported that the application of polymer promoted more adherence of chemicals on the seeds. This result indicates that the tested product is compatible and reflected on higher adhesion of the chemical on the seeds. Therefore, it ensured better seed protection and can reduce environmental impacts, such as soil contamination and pesticide leaching to groundwater.

To be considered adequate, a polymer must present determined characteristics. The coating must be stable in seed handling conditions encountered during the manufacturing, storage, distribution and sowing, be compatible with material to be incorporated with it, and must not be persistent in the soil after sowing (Accinelli et al., 2016). The retention of products used for seed treatment also depends on the adhesion of the applied product, compatibility among different formulations and the characteristics of the seed coating (Avelar et al., 2012).

The concentration of leached products may also vary according to the soil. According to Castro et al. (2008), the active ingredient thiamethoxam is highly leached from Red Latosol and less leached from Yellow-Red Latosol. This is due to soil characteristics, such as structure, sorption and compound degradation by this soil.

Leaching is related to the land cover, and consequently, uncovered soils may present faster leach than, for instance, no-till ones. The risk of groundwater contamination at levels which are toxic to humans depends on the groundwater depth and product toxicity (Castro et al., 2008).

The polymer application methods were not statistically different. Therefore, seed handling equipment should be better designed and more adequate, so that the polymer can more efficiently retain the chemical products and losses by leaching can be further reduced.

Looking at the total percentage of leachate, the use of polymer in the seed treatment prevented a loss of about $20 \%$ of the active ingredient when compared to the seed treatment without polymer. With more chemicals being retained on the seed, the treatment protects them more effectively and they may show better initial development under adverse conditions. In 
addition to greater seed protection, there is an environmental benefit as less product is leached into the soil.

In regard to physiological quality, the isolated effects of diameter and seed treatment were statistically significant for some variables (Table 4). Concerning the seed diameter effect, no statistically significant difference was found by analyzing the results of parameters vigor (FC), germination $(\mathrm{G})$, field emergence (FE), radicle length (RL) and hypocotyl length (HL).

Table 4. Means of the first count (FC), germination rate $(\mathrm{G})$, emergence in the field (FE), accelerated aging (AA), radicle length (RL), hypocotyl length (HL), dry mass (DM) and moisture content (MC) test results from soybean seeds presenting different diameters.

\begin{tabular}{ccccccccc}
\hline Diameter & FC $(\%)$ & G $(\%)$ & FE $(\%)$ & AA $(\%)$ & RL $(\mathrm{cm})$ & HL $(\mathrm{cm})$ & DM $(\mathrm{mg})$ & MC $(\%)$ \\
\hline 5.5 & $81^{\text {ns }}$ & $89^{\text {ns }}$ & $86^{\text {ns }}$ & $71 \mathrm{~b}^{*}$ & $13.66^{\text {ns }}$ & $6.78^{\text {ns }}$ & $28.65 \mathrm{~b}$ & $11.31^{\text {ns }}$ \\
6.5 & 79 & 89 & 86 & $79 \mathrm{a}$ & 13.84 & 6.31 & $31.71 \mathrm{a}$ & 11.44 \\
\hline $\mathrm{CV}(\%)$ & 6.43 & 6.79 & 5.03 & 5.42 & 7.6 & 9.9 & 5.97 & 0.5 \\
\hline
\end{tabular}

* Different letters in the columns indicate means with statistically significant differences in the Scott-Knott test at the 5\% significance level. ${ }^{\text {ns: }}$ non-significant in the $\mathrm{F}$ test at $5 \%$ probability.

For the accelerated aging parameter, seeds of larger diameter showed higher values. This result corroborates Vinhal-Freitas et al. (2011), who justified this result by pointing out the high temperature and high relative humidity of the air. This can promote a sharp increase in the metabolism of the seed, and when smaller ones are exposed to stress, their quality decreases more quickly. On the other hand, larger seeds will have more reserves to perform metabolic processes and thus greater capacity to originate normal seedlings.

By evaluating the parameter radicle dry mass, seed of larger diameter presented higher accumulation of phytomass. Similar results were obtained by Morais Soares et al. (2015) and Vinhal-Freitas et al. (2011) who linked them to the size or mass of seeds. This character reflects on the size of reserve tissues available for seedling development and directly influences the transference of mass from the cotyledons to the seedlings.

By observing the isolated factor treatment (Table 5), the results of parameters first count $(\mathrm{FC})$, germination rate $(\mathrm{G})$, field emergence $(\mathrm{FM})$, accelerated aging (AA) and radicle dry mass (RDM) indicate a non-significant difference among the different seed methods. Those results demonstrated that the use of polymers in seed treatment did not affect the physiological quality of the seeds. These results support the findings of Ludwig et al. (2011) and Brzezinski et al. (2015), who obtained no significant difference among treatments in soybeans. These previous studies indicated that the treatments did not affect the physiological quality obtained through germination and vigor tests.

Table 5. Means of the first count (FC), germination rate (G), emergence in the field (FE), accelerated aging (AA), radicle length (RL), hypocotyl length (HL), dry mass (DM) and moisture content (MC) test results from soybean seeds undergone different phytosanitary and polymers treatments.

\begin{tabular}{ccccccccc}
\hline Treatment & FC $(\%)$ & G $(\%)$ & FE $(\%)$ & AA $(\%)$ & RL $(\mathrm{cm})$ & HL $(\mathrm{cm})$ & DM $(\mathrm{mg})$ & MC $(\%)$ \\
\hline Control & $77 \mathrm{a}^{*}$ & $86 \mathrm{a}$ & $89 \mathrm{a}$ & $76 \mathrm{a}$ & $13.15 \mathrm{a}$ & $7.42 \mathrm{a}$ & $30.73 \mathrm{a}$ & $10.95 \mathrm{a}$ \\
Treat+pol & $80 \mathrm{a}$ & $91 \mathrm{a}$ & $86 \mathrm{a}$ & $75 \mathrm{a}$ & $14.35 \mathrm{a}$ & $6.25 \mathrm{~b}$ & $30.18 \mathrm{a}$ & $11.53 \mathrm{~b}$ \\
Treat/pol & $83 \mathrm{a}$ & $91 \mathrm{a}$ & $84 \mathrm{a}$ & $73 \mathrm{a}$ & $13.57 \mathrm{a}$ & $6.22 \mathrm{~b}$ & $29.8 \mathrm{a}$ & $11.60 \mathrm{~b}$ \\
Treat & $81 \mathrm{a}$ & $90 \mathrm{a}$ & $86 \mathrm{a}$ & $70 \mathrm{a}$ & $13.93 \mathrm{a}$ & $6.29 \mathrm{~b}$ & $30 \mathrm{a}$ & $11.41 \mathrm{~b}$ \\
\hline CV $(\%)$ & 6.43 & 6.79 & 5.03 & 5.42 & 7.6 & 9.9 & 5.97 & 0.5 \\
\hline
\end{tabular}

* Different letters in the columns indicate means with statistically significant differences in the Scott-Knott test at the 5\% significance level. 
However, there was a significant difference among the evaluated seed treatments when the variable hypocotyl length was accessed. The control presented higher values when compared to the other treatments. These results corroborate Ludwig et al. (2014) who suggests that these results are due to phytotoxic effect of the higher concentration of the chemical on the germitest paper during the initial growth of the seedling.

Generally speaking, seed treatment should not have a negative impact on the quality and early development of seed, but rather should protect them against adverse conditions. In order to consider a treatment appropriate, it should not be toxic to seeds so that the germination and seedling emergence are not negatively impacted (Keawkham et al., 2014).

Differences in the moisture content of the seeds were found. Those treated by any of the analyzed treatments presented higher values in comparison to control seeds. Even though the moisture contents were higher, the values are below the limit of $14 \%$ which, according to Smaniotto et al. (2014), is suitable for seed storage. Limiting the moisture contents to this value avoids mechanical damage and pathogen attacks that can lead to lower vigor.

\section{CONCLUSIONS}

The use of polymers associated with seed treatment is efficient in reducing losses by leaching, preventing a loss of about $20 \%$ of the active ingredient when compared to the seed treatment without polymer. No significant difference was found by comparing the water holding capacity and physiological quality of seed treated with two distinct polymer application methods. Moreover, larger seeds presented greater vigor, though the germination rate was similar.

\section{REFERENCES}

ACCINELli, C.; ABBAS, H. K.; LITTLE, N. S.; KOTOWICZ, J. K.; MENCARELLI, M.; SHIER, W. T. A. liquid bioplastic formulation for film coating of agronomic seeds. Crop Protection, v. 89, p. 123-128, 2016. https://doi.org/10.1016/j.cropro.2016.07.010

ARFAOUI, A.; EL HADRAMI, A.; DAAYF, F. Pre-treatment of soybean plants with calcium stimulates ROS responses and mitigates infection by Sclerotinia sclerotiorum. Plant $\begin{array}{llllll}\text { Physiology and Biochemistry, v. 122, p. 121-128, } 2018 . & \end{array}$ https://doi.org/10.1016/j.plaphy.2017.11.014

AVELAR, S. A. G.; SOUSA, F. V. D.; FISS, G.; BAUDET, L.; PESKE, S. T. The use of film coating on the performance of treated corn seed. Revista Brasileira de Sementes, v. 34, n. 2, p. 186-192, 2012. http://doi.org/10.1590/S0101-31222012000200001

BALARDIN, R. S.; SILVA, F. D. L.; DEBONA, D.; CORTE, G. D.; FAVERA, D. D.; TORMEN, N. R. Tratamento de sementes com fungicidas e inseticidas como redutores dos efeitos do estresse hídrico em plantas de soja. Ciência Rural, v.41, n.7, p.1120-1126, 2011. http://doi.org/10.1590/S0103-84782011000700002

BRASIL. Ministério da Agricultura, Pecuária e Abastecimento. Regras para Análise de Sementes. Brasília: Mapa/ACS, 2009. 395 p.

BRZEZINSKI, C. R.; HENNING, A. A.; ABATI, J.; HENNING, F. A.; FRANÇA-NETO, J. D. B.; KRZYZANOWSKI, F. C.; ZUCARELI, C. Seeds treatment times in the establishment and yield performance of soybean crops. Journal of Seed Science, v. 37, n. 2, 147-153, 2015. http://doi.org/10.1590/2317-1545v37n2148363 
CAMozZATO, V. A.; PESKE, S. T.; POSSENTI, J.; MENDES, A. S. Desempenho de cultivares de soja em função do tamanho das sementes. Revista brasileira de sementes, v. 31, n. 1, p. 288-292, 2009. http://doi.org/10.1590/S0101-31222009000100032

CARVAlHO, N. M.; NAKAGAWA, J. Sementes: Ciência, Tecnologia e Produção. 5. ed. Jaboticabal: Funep, 2012. 590 p.

CASTRO, N. R. A.; RIGITANO, R. L. D. O.; LIMA, J. M. D.; GUERREIRO, M. C. Lixiviação do inseticida thiamethoxam em macrolisímetros de duas classes de solo. Ciência e agrotecnologia, v. 32, n. 6, p. 1818-1823. 2008. http://doi.org/10.1590/S141370542008000600021

FAGUNDES, L. K.; NUNES, U. R.; PRESTES, O. D.; FERNANDES, T. S.; LUDWIG, E. J.; SAIBT, N. Rice seed treatment and recoating with polymers: physiological quality and retention of chemical products. Revista Caatinga, v. 30 n. 4, p. 920-927, 2017 http://doi.org/10.1590/1983-21252017v30n412rc

HESLER, L. S.; ALLEN, K. C.; LUTTRELL, R. G.; SAPPINGTON, T. W.; PAPIERNIK, S. K. Early-season pests of soybean in the United States and factors that affect their risk of infestation. Journal of Integrated Pest Management, v. 9, n. 1, p. 19, 2018. https://doi.org/10.1093/jipm/pmx028

IOANNOU, A.; GOHARI, G.; PAPAPHILIPPOU, P.; PANAHIRAD, S.; AKBARI, A.; DADPOUR, M. R.; KRASIA-CHRISTOFOROU, T.; FOTOPOULOS, V. Advanced nanomaterials in agriculture under a changing climate: The way to The future? Environmental and Experimental Botany, v. 176, p. 1-14, 2020. https://doi.org/10.1016/j.envexpbot.2020.104048

KEAWKHAM, T.; SIRI, B.; HYNES, R. K. Effect of polymer seed coating and seed dressing with pesticides on seed quality and storability of hybrid cucumber. Australian Journal of Crop Science, v. 8, n. 10, p. 1415, 2014.

KEMMERICH, M.; RIZZETTI, T. M.; MARTINS, M. L.; PRESTES, O. D.; ADAIME, M. B.; ZANELLA, R. Optimization by central composite design of a modified QuEChERS method for extraction of pesticide multiresidue in sweet pepper and analysis by ultrahigh-performance liquid chromatography-tandem mass spectrometry. Food analytical methods, v. 8, n. 3, p. 728-739, 2014. https://doi.org/10.1007/s12161-014-9951-2

KOPPER, A. C.; MALAVASI, M. DE M.; MALAVASI, U. C. Influência da temperatura e do substrato na germinação de sementes de Cariniana estrellensis (Raddi) Kuntze. Revista Brasileira de Sementes, v. 32, n. 2, p. 160-165, 2010. http://doi.org/10.1590/S010131222010000200020

LIMA, L. B.; DA SILVA, P. A.; GUIMARÃES, R. M.; OLIVEIRA, J. A. Peliculização e tratamento químico de sementes de algodoeiro. Ciência e Agrotecnologia, v. 30, p. 10911098, 2006. http://doi.org/10.1590/S1413-70542006000600007

LUDWIG, E. J.; NUNES, U. R.; MERTZ, L. M.; DA SILVA, J. R.; NUNES, S. C. P. Vigor e produção de sementes de crambe tratadas com fungicida, inseticida e polímero. Científica, v. 42, n. 3, p. 271-277, 2014. http://doi.org/10.15361/1984$5529.2014 \mathrm{v} 42 \mathrm{n} 3 \mathrm{p} 271-277$

LUDWIG, M. P.; LUCCA FILHO, O. A.; BAUDET, L.; DUTRA, L. M. C.; AVELAR, S. A. G.; CRIZEL, R. L.; OLIVEIRA, S. Eficiência do recobrimento de sementes de soja em equipamento com sistema de aspersão. Ciência Rural, v. 41, n. 4, 2011. http://doi.org/10.1590/S0103-84782011005000023 
MORAIS SOARES, M.; CARVALHO, J. S.; H., SIMÕES, M. G.; PAZZIN, D.; JUNIO DA SILVA, L. Estresse hídrico e salino em sementes de soja classificadas em diferentes tamanhos. Pesquisa Agropecuária Tropical, v. 45, n. 4, 2015. http://doi.org/10.1590/1983-40632015v4535357

PADUA, G. P.; ZITO, R. K.; ARANTES, N. E.; NETO, F. Influência do tamanho da semente na qualidade fisiológica e na produtividade da cultura da soja, Revista Brasileira de Sementes, v. $32, \quad \mathrm{n} \quad 3$ p. 009-016, 2010. http://doi.org/10.1590/S010131222010000300001

SEGALIN, S. R.; BARBIERI, A. P. P.; HUTH, C.; BECHE, M.; MATTIONI, N. M.; MERTZ, L. M. Physiological quality of soybean seeds treated with different spray volumes. Journal of Seed Science, v. 35, n. 4, p. 501-509, 2013. http://doi.org/10.1590/S231715372013000400012

SMANIOTTO, T. A. D. S.; RESENDE, O.; MARÇAL, K. A.; DE OLIVEIRA, D. E.; SIMON, G. A. Physiological quality of soybean seeds stored in different conditions. Revista Brasileira de Engenharia Agrícola e Ambiental, v. 18, n. 4, p. 446-453, 2014. http://doi.org/10.1590/S1415-43662014000400013

VIJAYA MAHANTESH, B. N.; RAI, P. K.; SRIVASTAVA, D. K.; BARA, B. M.; KUMAR, R. Effects of polymer seed coating, fungicide seed treatment and storage duration on seedling characteristics of cotton (Gossypium hirsutum) seeds. Journal of Pharmacognosy and Phytochemistry, v. 6, n. 4, p. 534-536, 2017.

VINHAL-FREITAS, I. C.; GARCIA JUNIOR, J. E.; SEGUNDO, J. P.; VILARINHO, M. S. Germinação e vigor de sementes de soja classificadas em diferentes tamanhos. Agropecuária Técnica, v. 32, n. 1, p. 108-114, 2011.

ZHANG, F.; GE, H.; ZHANG, F.; GUO, N.; WANG, Y.; CHEN, L.; LI, C. Biocontrol potential of Trichoderma harzianum isolate T-aloe against Sclerotinia sclerotiorum in soybean. Plant Physiology and Biochemistry, v. 100, p. 64-74, 2016. https://doi.org/10.1016/j.plaphy.2015.12.017 


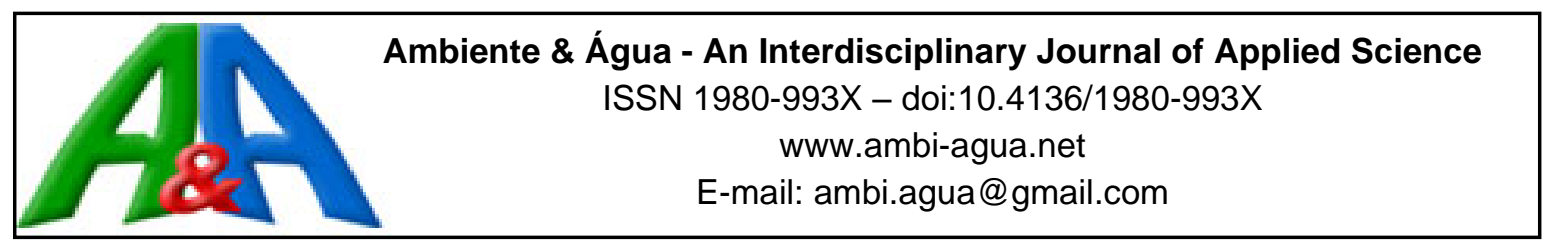

\title{
Monitoring of fluoride in the public water supply using electrometric or colorimetric analyses
}

\author{
ARTICLES doi:10.4136/ambi-agua.2603
}

Received: 25 Jun. 2020; Accepted: 05 Oct. 2020

\author{
Caio Luiz Lins-Candeiro' ${ }^{(D)}$; Karen Katlein Dolenkei ${ }^{1}$ (D); \\ Luiz Renato Paranhos ${ }^{2}$; Douglas Queiroz Santos ${ }^{3}$; \\ Jaime Aparecido Cury ${ }^{4}$; Juliana Pereira da Silva Faquim ${ }^{3 *}$ \\ ${ }^{1}$ Faculdade de Odontologia. Universidade Federal de Uberlândia (UFU), Avenida Pará, \\ n 1720, CEP: 38405320, Uberlândia, MG, Brazil. \\ E-mail: caiocandeiro@yahoo.com.br, karendolenkei@hotmail.com \\ ${ }^{2}$ Departamento de Odontologia Preventiva e Social. Faculdade de Odontologia. \\ Universidade Federal de Uberlândia (UFU), Avenida Pará, n 1720, CEP: 38405320, Uberlândia, MG, Brazil. \\ E-mail: paranhos.lrp@gmail.com \\ ${ }^{3}$ Escola Técnica de Saúde. Universidade Federal de Uberlândia (UFU), Avenida Amazonas, Bloco 4K, \\ CEP: 38400-902, Uberlândia, MG, Brazil. E-mail: douglas@ufu.br \\ ${ }^{4}$ Escola de Odontologia de Piracicaba. Departamento de Biociências. Universidade Estadual de Campinas \\ (UNICAMP), Avenida Limeira, n 910, CEP: 13414-903, Piracicaba, SP, Brazil. E-mail: jcury@unicamp.br \\ *Corresponding author. E-mail: julianafaquim@ufu.br
}

\begin{abstract}
The surveillance of the concentration of fluoride in the public water supply aims to ensure the balance between the benefits (carie prevention) and risk (dental fluorosis) of water fluoridation programs. The aim of this study was to check the accuracy of two analytical methods for monitoring the concentration of fluoride in the public water supply of a Brazilian city. The STROBE checklist was used to aid the conduction of this study and report the results. It was an analytical, observational, and prospective study using the water supply of Uberlândia, MG, Brazil. We collected 126 water samples at 21 sites for six consecutive months and analyzed them using the fluoride ion selective electrode (F-ISE) method and colorimetry with SPADNS. The statistical analysis was performed descriptively and then the ANOVA and Student $t$-test for paired samples were applied. The results showed that the F-ISE method had a lower coefficient of variation $(12.3 \%)$ than the SPADNS method $(57.4 \%)$. There was no significant variation of the fluoride concentration in the water through the supply network evaluated either by F-ISE as SPADNS. We concluded that the electrometric method should be the first choice for use by laboratories that monitor fluoride concentration in the public supply water.
\end{abstract}

Keywords: fluoridation, sanitary surveillance, water supply.

\section{Monitoramento de flúor no abastecimento público de água por meio de análises eletrométricas e colorimétricas}

\section{RESUMO}

A vigilância da concentração de flúor na água de abastecimento público visa garantir o equilíbrio entre o benefício (prevenção de cárie) e risco (fluorose dental) dos programas da 
fluoretação de água. O objetivo deste estudo foi verificar a precisão de dois métodos analíticos no monitoramento da concentração de flúor na água de abastecimento público de uma cidade brasileira. O checklist STROBE foi utilizado para auxiliar na condução desta pesquisa e relatar os resultados. Tratou-se de um estudo observacional analítico, de caráter prospectivo utilizando a água de abastecimento de Uberlândia, MG. Foram coletadas 126 amostras de água, em 21 pontos, durante seis meses seguidos e analisadas por meio do método com eletrodo íon seletivo (F-SIE) e por colorimetria com o SPADNS. A análise estatística foi realizada de maneira descritiva, em seguida, empregou-se o teste ANOVA e o teste $t$ de Student para amostras pareadas. Os resultados mostraram que o método eletrométrico mostrou menor coeficiente de variação $(12,3 \%)$ quando comparado o método colorimétrico $(57,4 \%)$. Não foi observada variação significativa da concentração de fluoreto na água avaliada pelo F-ISE e SPADNS. Conclui-se que o método eletrométrico deve ser de primeira escolha para ser utilizado por laboratórios que monitoram a concentração de flúor nas águas de abastecimento público.

Palavras-chave: abastecimento de água, fluoretação, vigilância sanitária.

\section{INTRODUCTION}

Fluorine is considered the main reason for decreasing cases of carie diseases worldwide (Maia et al., 2003; Cho et al., 2014; Jordan et al., 2017). Over four decades, fluorine has been used for controlling dental caries, resulting in a significant improvement in the oral health of the population (Frazão et al., 2018). Fluorine presents low cost (Leivas et al., 2010), high effectiveness (Frazão et al., 2018), and especially an extensive population coverage, regardless of age and social and economic conditions (Burt, 2002; Petersen and Lennon, 2004).

Providing a more effective delivery of the benefit to the population requires that the fluoride concentration remains at an "optimal level" (Amaral et al., 2007). Hence, controlling fluorine concentration in the public water supply is essential, as well as the operational control performed by companies in water treatment plants (Frazão et al., 2018).

Regardless of the local temperature, there is great variability in fluorine concentrations in the water (Buzalaf et al., 2013; Paredes et al., 2014; Bergamo et al., 2015; Piorunneck et al., 2017; Uchida et al., 2018). Determining fluoride in the water requires the use of the electrometric method with specific ion electrode by the direct method, as well as the colorimetric method by the SPADNS method or the Alizarine visual colorimetric method (APHA et al., 2012). The Ion Chromatography method is also used (Dovidauskas et al., 2017) but sporadically.

This study compared two assessment methods of fluoride concentration in the public water supply and determined the better one to use as an oral health surveillance tool. The following hypotheses were tested: (1) The electrometric method presents a lower coefficient of variation than the colorimetric method; (2) There are differences in fluorine ion concentrations between the population receiving water in regions distant from the site of fluoride addition and the population living close to the Water Treatment Plants.

\section{MATERIALS AND METHODS}

\subsection{Ethical research criteria and protocol}

This was an observational study that did not involve human beings and animals, therefore its submission to the Research Ethics Committee was not required. The STROBE checklist Strengthening the Reporting of Observational Studies in Epidemiology (Von Elm et al., 2008) was used to aid the research and the reporting of results. 


\subsection{Type and characterization of the study location}

It was an analytical, observational, and prospective study performed in the city of Uberlândia, Minas Gerais - southeast region of Brazil. The city of Uberlândia, according to the Brazilian Institute of Geography and Statistics (IBGE, 2020) for 2016, has an estimate of 669,672 inhabitants - the second largest city of the state of Minas Gerais. According to the report of the Trata Brasil Institute (Instituto Trata Brasil, 2016), Uberlândia has the third best sanitation service in Brazil and it is considered a reference. The city also has $100 \%$ water coverage and $99 \%$ sewage collection coverage. One hundred percent of the sewage collected is treated.

In 1967, the city government created the Municipal Department of Water and Sewage (DMAE), establishing the construction of the first Water Treatment Plant (WTP). Currently, Uberlândia has two working plants (Sucupira WTP and Bom Jardim WTP) and one more under construction (Capim Branco WTP). Figure 1 shows the coverage area of each WTP. The north and east sections are supplied by the Bom Jardim WTP and the central, south, and west sections are supplied by the Sucupira WTP. It is worth noting that a small area of the west section is supplied by both WTPs.

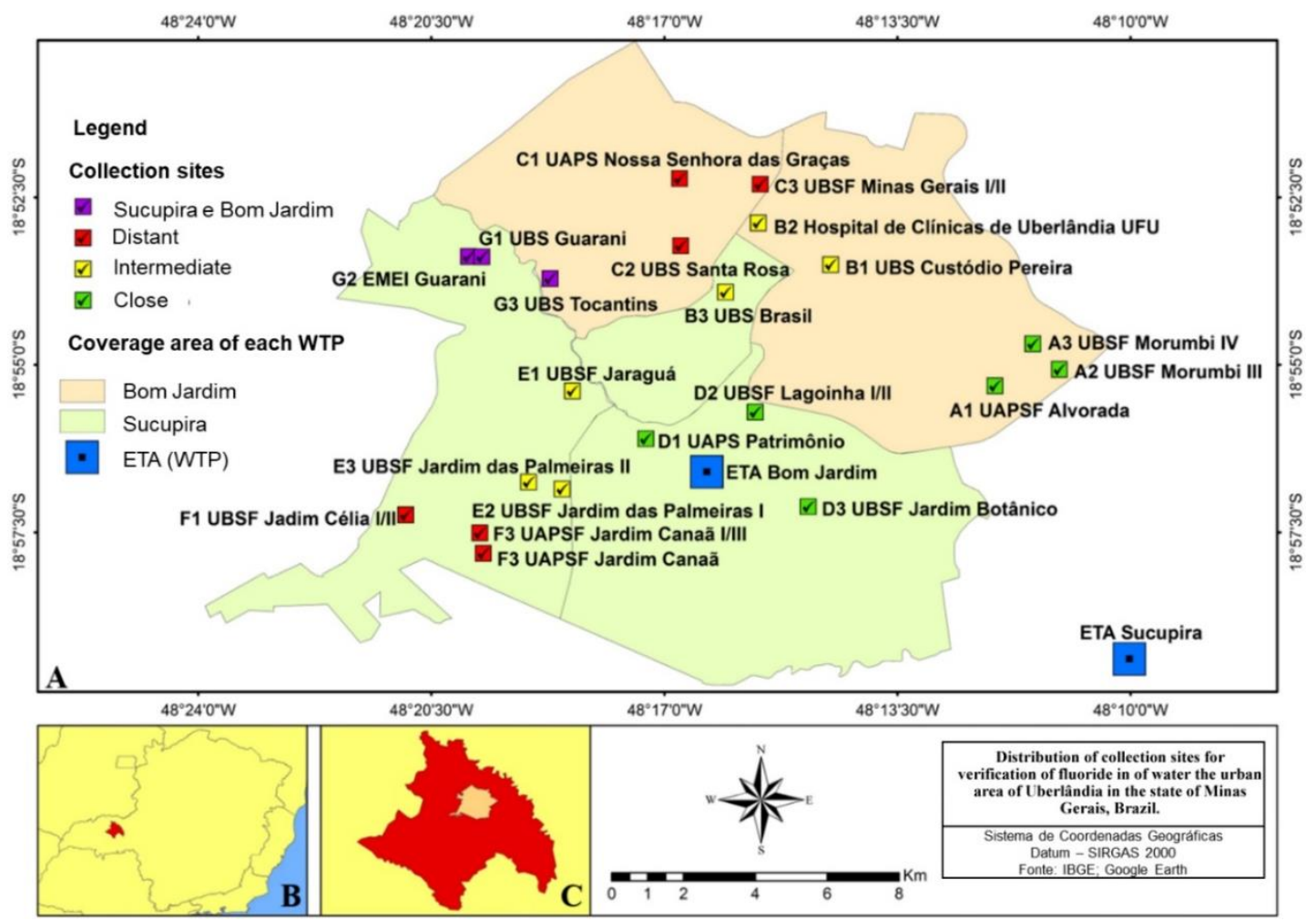

Figure 1. A) Distribution of collection sites in the urban area of Uberlândia. B) Location of the city of Uberlândia in the state of Minas Gerais, Brazil. C) Delimitation of the urban area in the territory extension of the city (Lins-Candeiro, 2018).

To define the collection sites, we analyzed the representativity and space coverage of each WTP, following the branch supply network. Hence, it was required to understand the water distribution network of the city, locate the number of treatment plants, and identify the existence of alternative collective solutions and the coverage of these systems.

Three main sites were defined, with one close to the WTP, an intermediate, and one distant from the WTP. For each of these three main sites, two additional close sites were established (Figure 2). Thus, there were a total of nine sites for each WTP and three additional collection sites for the region supplied by both WTPs. The locations prioritized for such collections were health units and public schools. 


\section{DEFINITION OF THE NUMBER OF WATER COLLECTION SITES}
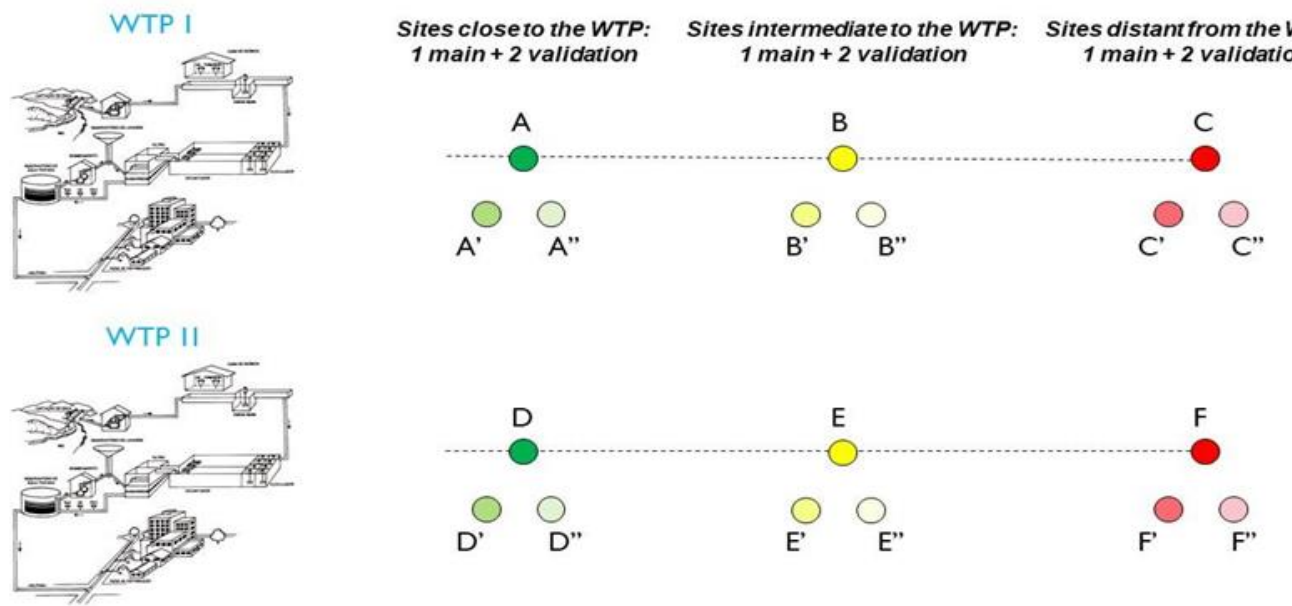

Figure 2. Adapted and summarized scheme of the sampling method for the analysis of fluoride in the city of Uberlândia, MG, Brazil. To the collection site A1 (main site), two more validation sites (A2 and A3) are added close to the WTP. Sites B1, B2, and B3 correspond to the collection sites at an intermediate distance from the WTP. Sites C1, C2, and $\mathrm{C} 3$ refer to the collections distant from the WTP. Sites D, E, F, and G followed the same dynamic of sites A, B, and C (CECOL, 2011).

The city has a region where the population is supplied by both WTPs (Bom Jardim and Sucupira). Therefore, the study chose to draw three additional collection sites in this region to assess the water supplying the population. The samples received the letter $G$ for identification in the results tables.

The collections were performed once a month for six months (CECOL, 2014). One hundred and twenty-six water samples were collected in plastic recipients with a natural pressure cap and capacity of $20 \mathrm{~mL}$, which were identified previously with a permanent marker. The water samples collected were analyzed in the laboratory of the Technical Course in Environmental Control and Environment of the Technical School of Health of the Federal University of Uberlândia.

\subsection{Description of methods}

The electrometric and colorimetric methods were performed to quantify the fluorine ion content in the samples collected. The electrometric method is based on the direct measurement of free fluorine ions and it uses the fluoride ion selective electrode (F-ISE) as the main tool. This electrode has a fluoride crystal membrane from which a potential is established by fluoride solutions of different concentrations, determining the calibration of the electrode. Quantification occurs when the electrode is immersed in the solution (sample and reagent) and the crystal contacts the sample solution on one surface and the internal reference solution on the other surface. When removing the electrode, it is important to rinse it with distilled water and dry it in-between readings. The minimum reading range in the quantification of the fluorides of this method is approximately $0.02 \mathrm{ppm}$ of $\mathrm{F}^{-}$and the maximum is $19000 \mathrm{ppm}$ of fluorine (APHA et al., 2012).

The principle of the colorimetric method is the reading method based on the reaction between fluorine and a zirconium-dye lake. According to the amount of fluorine, the liquid becomes lighter (more fluorine) or darker (less fluorine), and the filter photometer provides the concentration value. For this method, the minimum reading value in the quantification of fluorides is $0.05 \mathrm{ppm} \mathrm{F}^{-}$and the maximum value is $2.0 \mathrm{ppm}$ of fluorine (APHA et al., 2012). 


\subsection{Data collection}

The samples were analyzed with a selective ion electrode (Analion ${ }^{\mathrm{TM}}$ ) coupled to a potentiometer (Adwa ${ }^{\mathrm{TM}}$ model AD 1000) for the electrometric method and with a SPADNS solution analysis kit for the colorimetric method by Nanocolor REF 918142. The reagent used in the samples for the electrometric analysis was the TISAB II (Total Ionic Strength Adjustment Buffer II), pH 5.0, in the standards of 0.125 - 0.500 - 1.000 ppm F'.

The electrode used was calibrated before the analysis with standards between 0.125 and $1.0 \mathrm{ppm} \mathrm{F}^{-}$. In the interval between assessments, the electrode was washed with distilled and deionized water and dried with an absorbent paper towel. For the colorimetric method, the reagent was added to the samples and after five minutes it was subjected to the spectrophotometer to analyze the concentration of $\mathrm{F}^{-}$. The results were expressed in $\mathrm{mg} \mathrm{F}^{-} / \mathrm{L}$ $(\mathrm{ppm} \mathrm{F})^{-}$.

\subsection{Data analysis}

Initially, a descriptive statistical analysis was performed to characterize the samples. Next, ANOVA was used to identify significant differences in water fluoridation within the months of the study and the different collection sites. Student t-test for paired samples was also performed to compare the results obtained with the electrometric and colorimetric methods (Larson and Farber, 2016). The significance level was set at 5\% ( $<<0.05)$. All analyses were performed with the help of the IBM SPSS Statistics software, Version 20.0, considering a 95\% confidence interval to obtain the estimates.

\section{RESULTS}

The data reported between November 2015 and April $2016(n=126)$ revealed the mean monthly values of the fluoride concentration in the public water supply. The differences between the monthly means, calculated with repeated measures ANOVA, showed a statistically significant difference in water fluoridation between the months collected $(p<0.001)$ for each method monitored. The Table 1 shows the monthly means assessed.

Table 1. Mean of fluoride contents in the public water supply in Uberlândia (MG), Brazil, for all collection sites.

\begin{tabular}{ccccc}
\hline & \multicolumn{2}{c}{ Electrometric Method } & \multicolumn{2}{c}{ Colorimetric Method } \\
\cline { 2 - 5 } Period & $\begin{array}{c}\text { Fluorine Content } \\
(\mathbf{p p m F})\end{array}$ & $\begin{array}{c}\text { Standard deviation } \\
(\mathbf{p p m})\end{array}$ & $\begin{array}{c}\text { Fluorine Content } \\
(\mathbf{p p m F})\end{array}$ & $\begin{array}{c}\text { Standard deviation } \\
(\mathbf{p p m F})\end{array}$ \\
\hline November/2015 & 0.62 & 0.07 & 0.72 & 0.10 \\
December/2015 & 0.60 & 0.04 & 0.33 & 0.11 \\
January/2016 & 0.55 & 0.08 & 0.38 & 0.17 \\
February/2016 & 0.60 & 0.03 & 0.73 & 0.09 \\
March/2016 & 0.56 & 0.04 & 1.29 & 0.52 \\
April/2016 & 0.53 & 0.08 & 0.65 & 0.08 \\
\hline General & $\mathbf{0 . 5 7}$ & $\mathbf{0 . 0 7}$ & $\mathbf{0 . 6 8}$ & $\mathbf{0 . 3 9}$ \\
\hline
\end{tabular}

Note: Differences between the monthly means (ANOVA test for repeated measures, $p<0.001$ ); Differences between two methods (Student $\mathrm{t}$-test for paired samples, $\mathrm{p}=0.002$ ).

Using the electrometric method evidenced a general mean of $0.57 \mathrm{ppm} \mathrm{F}^{-}$, which was considered moderate for carie prevention. The month of November showed the highest fluorine concentration $(0.62 \pm 0.07)$, while the lowest was seen in April $(0.53 \pm 0.08)$. The colorimetric method presented a general mean of $0.68 \mathrm{ppm} \mathrm{F}^{-}$. The month of March showed the highest fluoride concentration $(1.29 \pm 0.52)$ and the lowest was seen in December $(0.33 \pm 0.11)$. The 
comparison between these two methods, performed by the Student t-test for paired samples, showed statistically significant differences $(p=0.002)$.

The results showed that the mean value of fluoride in the water is lower when assessed by the electrometric method $(0.57 \pm 0.07)$ than the colorimetric method $(0.68 \pm 0.39)$. However, when analyzing the fluorine concentration of the water samples according to the collection sites (Table 2), the colorimetric method showed a higher coefficient of variance (57.4\%) than the electrometric method (12.3\%).

Table 2. Fluorine concentration of the water samples according to the collection site in Uberlândia (MG), Brazil, by collection site.

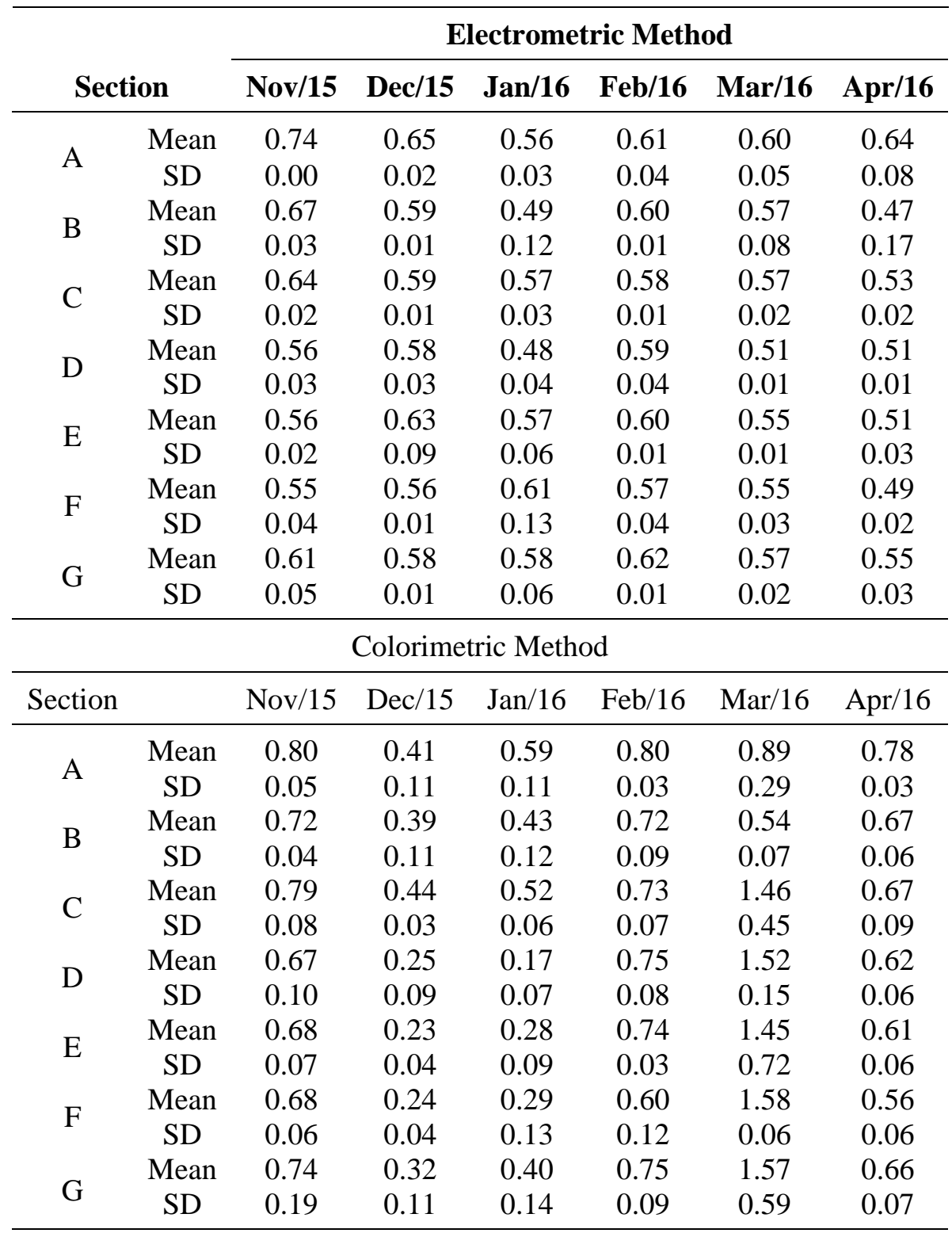

Note: Descriptive statistics; $\mathrm{SD}=$ standard deviation.

Lastly, the mean fluoride values were compared using ANOVA according to the distance of water collection sites relative to the WTP in Uberlândia (close, intermediate, and distant), aiming to investigate some variation of concentration to be attributed to the water distribution network (Table 3). However, there were no statistically significant differences regarding the distance of collection sites relative to the WTP when comparing the results obtained with the electrometric $(p=0.815)$ and colorimetric $(p=0.155)$ methods. 
Table 3. Mean fluorine concentration of the water samples according to the distance of water collection sites relative to the WTP in Uberlândia (MG), Brazil.

\begin{tabular}{|c|c|c|c|c|c|c|c|}
\hline \multirow{2}{*}{ Collection sites } & & \multicolumn{6}{|c|}{ Electrometric Method } \\
\hline & & Nov/15 & Dec/15 & Jan/16 & Feb/16 & Mar/16 & Apr/16 \\
\hline \multirow{2}{*}{ Close } & Mean & 0.65 & 0.61 & 0.52 & 0.60 & 0.56 & 0.57 \\
\hline & $\mathrm{SD}$ & 0.10 & 0.05 & 0.05 & 0.03 & 0.06 & 0.09 \\
\hline \multirow{2}{*}{ Intermediate } & Mean & 0.62 & 0.61 & 0.53 & 0.60 & 0.56 & 0.49 \\
\hline & SD & 0.06 & 0.06 & 0.10 & 0.01 & 0.05 & 0.11 \\
\hline \multirow{2}{*}{ Distant } & Mean & 0.59 & 0.58 & 0.59 & 0.58 & 0.56 & 0.51 \\
\hline & $\mathrm{SD}$ & 0.06 & 0.02 & 0.08 & 0.03 & 0.02 & 0.03 \\
\hline \multirow{2}{*}{ Sucupira and Bom Jardim } & Mean & 0.61 & 0.58 & 0.58 & 0.62 & 0.57 & 0.55 \\
\hline & $\mathrm{SD}$ & 0.05 & 0.01 & 0.06 & 0.01 & 0.02 & 0.03 \\
\hline \multicolumn{8}{|c|}{ Colorimetric Method } \\
\hline \multicolumn{2}{|l|}{ Collection sites } & Nov/15 & Dec/15 & $\mathrm{Jan} / 16$ & Feb/16 & Mar/16 & Apr/16 \\
\hline \multirow{2}{*}{ Close } & Mean & 0.74 & 0.33 & 0.38 & 0.78 & 1.20 & 0.70 \\
\hline & $\mathrm{SD}$ & 0.10 & 0.12 & 0.25 & 0.06 & 0.40 & 0.10 \\
\hline \multirow{2}{*}{ Intermediate } & Mean & 0.70 & 0.31 & 0.36 & 0.73 & 0.99 & 0.64 \\
\hline & SD & 0.06 & 0.12 & 0.12 & 0.06 & 0.68 & 0.06 \\
\hline \multirow{2}{*}{ Distant } & Mean & 0.73 & 0.34 & 0.41 & 0.66 & 1.52 & 0.62 \\
\hline & SD & 0.08 & 0.11 & 0.15 & 0.11 & 0.29 & 0.09 \\
\hline \multirow{2}{*}{ Sucupira and Bom Jardim } & Mean & 0.74 & 0.32 & 0.40 & 0.75 & 1.57 & 0.66 \\
\hline & $\mathrm{SD}$ & 0.19 & 0.11 & 0.14 & 0.09 & 0.59 & 0.07 \\
\hline
\end{tabular}

Note: ANOVA for electrometric $(\mathrm{p}=0.815)$ and colorimetric $(\mathrm{p}=0.155)$ methods.

\section{DISCUSSION}

This study compared the electrometric and colorimetric methods to verify the fluorine ion concentration in the public water supply. The results showed that the electrometric method had a lower variation than the colorimetric method. Moreover, none of the methods studied showed a reduction in the fluoride concentration from the WTP up to the farthest collection sites, which suggests there are no hidden wells through the network because ANOVA did not show statistical differences.

The results of the present study indicate that the electrometric method has a higher coefficient of variance than the colorimetric method, which means that the electrometric method presents higher precision. Similar results were observed in other studies (Ferreira and Benedet, 1999; Motter et al., 2011). The electrometric method has higher precision than the colorimetric method (alizarine and spectrophotometric) in the presence of fluoride at $0.6 \mathrm{ppm}$ (Ferreira and Benedet, 1999). The colorimetric method presented, on average, double the fluoride concentration when compared with the electrometric method, which may be explained by the interference it suffers from chemical substances such as chloride $\left(\mathrm{Cl}^{-}\right)$, hexametaphosphate $\left(\left[\mathrm{NaPO}_{2}\right]_{6}\right)$, phosphate $\left(\mathrm{PO}_{4}{ }^{3-}\right)$, aluminum $\left(\mathrm{Al}^{3+}\right)$, iron $(\mathrm{Fe})$, or sulfate $\left(\mathrm{SO}_{4}{ }^{2-}\right)$. It is worth noting that, despite the fact that these substances also interfere with the electrometric method, the effect is smaller (APHA et al., 2012). There are also limitations for the use of the colorimetric method, considering that samples cannot be cloudy or colored, should be distilled before the analysis (APHA et al., 2012; Prasad et al., 2018), and cannot contain free residual chlorine (Dovidauskas et al., 2016).

While these limitations are presented for the colorimetric method, the electrometric method does not require any type of sample preparation (APHA et al., 2012), which makes it easy to perform, considering it is exempt from a previous analysis phase (Moimaz et al., 2015) and consequently has a lower cost (Bratovcic et al., 2009; Dovidauskas et al., 2016; Balkunde et al., 2016). Thus, this study suggests that the electrometric method be used as the main method 
for surveilling the quality of water fluoridation (Ramires and Buzalaf, 2007; Do Carmo et al., 2010; Leivas et al., 2010; Moimaz et al., 2012; De Brito et al., 2016; Uchida et al., 2018).

The results presented in studies (Zimmer et al., 2003; Leivas et al., 2010; De Brito et al., 2016) did not assess the difference of $\mathrm{F}^{-}$among sites close, intermediate, and distant from the WTP. The analyses of fluorine contents in this study at the sites from the WTP did not show a loss of fluorine through the water distribution network, suggesting there is no chemical reaction of fluorine.

The results of this study also show that, despite not being included in the central objective of the investigation, it is worth noting that the mean fluoride level in the city studied was lower than that recommended for the local characteristics. The mean temperature of the collection months was $25.75^{\circ} \mathrm{C}$, therefore suggesting a water fluorine content between 0.65 and 0.94 , which interval is considered a maximum benefit and low risk. However, the mean observed using the electrometric method was $0.57 \mathrm{ppm} \mathrm{F}^{-}$, a value considered a moderate benefit and low risk of fluorosis, as well as another study (Ramires and Buzalaf, 2007) that presented mean concentrations of $\mathrm{F}^{-}$. For the colorimetric method, the mean content of $\mathrm{F}^{-}$was $0.68 \mathrm{ppm} \mathrm{F}$, which value provides maximum benefit and low risk of fluorosis.

In this sense, it stands out that the city studied does not present an effective Oral Health Surveillance policy, not even for water fluoridation, which is restricted to operational control. Several studies recommend Oral Health Surveillance (Narvai, 2000; Zimmer et al., 2003; Lima et al., 2004; Moimaz et al., 2015; Frazão et al., 2018) for an external control besides operational control, thus providing the achievement of reliable results regarding fluoride levels (Ramires and Buzalaf, 2007; CECOL, 2011; Frazão et al., 2018), enhancing this public health strategy, promoting anti-carie coverage, and preventing fluorosis. Fluoridation control by institutions not involved directly in its operation is an essential condition to preserve the quality of the process and for information credibility (Lima et al., 2004; Olivati et al., 2011).

The low number of studies found comparing methods is an important limitation. However, the present study is original, indicates the most effective method, and it may easily be used to maintain a better standard of drinking water, allowing the implementation of public policies to maintain the quality of the health surveillance service.

The establishment of local Oral Health Surveillance policies is an essential measure to ensure that the fluorine concentration in the water supply is sufficient to provide the high effectiveness of fluorine ion and low risk of fluorosis. The investment in this type of policy should be directed to the use of the electrometric method in both the fluoride addition site and the sites distant from the WTP. Moreover, Oral Health Surveillance should include an understanding of the epidemiological dynamic of dental caries in the cities.

\section{CONCLUSION}

The electrometric and colorimetric methods for fluoride monitoring in the public water supply, when compared, present statistically different results and precision, and the electrometric method is the more precise. The distance between the WTP and the sampling sites does not affect statistically the fluoride content in the public water supply and there is a statistically significant difference in fluoride concentration regarding the sampling month.

\section{REFERENCES}

AMARAL, R. C.; WADA, R. S.; SOUSA, L. M. R. Concentração de fluoretos nas águas de abastecimento público relacionada à temperatura em Piracicaba - SP. Revista da Faculdade de Odontologia, v. 12, n. 3, p. 24-28, 2007. https://doi.org/10.5335/rfo.v12i3.1064 
APHA; AWWA; WEF. Standard Methods for the examination of water and wastewater. 22nd ed. Washington, 2012. $1496 \mathrm{p}$.

BALKUNDE, P.; KRISHNAN, S.; RAJKUMAR, S.; HALERY, N.; LEVIN, S. Monitoring of fluoride in water samples using a smartphone. The Science of the Total Environment. v. 551-552, p. 101-107, 2016. https://doi.org/10.1016/j.scitotenv.2016.01.156

BERGAMO, E. T. P.; BARBANA, M.; TERADA, R. S. S.; CURY, J. A.; FUJIMAKI, M. Fluoride concentrations in the water of Maringá, Brazil, considering the benefit/risk balance of caries and fluorosis. Brazilian Oral Research, v. 29, n. 1, p. 1-6, 2015. https://doi.org/10.1590/1807-3107bor-2015.vol29.0047

BRATOVCIC, A.; ODOBASIC, A.; CATIC, S. The advantages of the use of ion-selective potentiometry in relation to UV/VIS spectroscopy. Agriculturae Conspectus Scientificus, v. 74, n. 3, p. 139-142, 2009.

BURT, B. A. Fluoridation and social equity. Journal of Public Health Dentistry, v. 62, n. 4, p. 195-200, 2002. https://doi.org/10.1111/j.1752-7325.2002.tb03445.x

BUZALAF, M. A. R.; MORAES, C. M.; OLYMPIO, K. P. K; PESSAN, P.; GRIZZO, L. T.; SILVA, T. L.; MAGALHÃES, A. C.; OLIVEIRA, R. C.; GROISMAN, S.; RAMIRES, I. Seven years of external control of fluoride levels in the public water supply in Bauru, São Paulo, Brazil. Journal of Applied Oral Science, v. 21, n. 1, p. 92-98, 2013. https://doi.org/10.1590/1678-7757201302196

CECOL. Consenso técnico sobre classificação de águas de abastecimento público segundo o teor de flúor. Brasília, 2011.

CECOL. Guia de Amostragem para Vigilância da Concentração do Fluoreto na Água de Abastecimento Público. 2014. Available at: http://www.cecol.fsp.usp.br/dcms/uploads/arquivos/1411739637_ManualGuia_Amostragem-v.1.0.pdf. Access on 31 May 2020.

CHO, H. J.; JIN, B. H.; PARK, D. Y.; JUNG, S. H.; LEE, H. S.; PAIK, D. I.; BAE, K. H. Systemic effect of water fluoridation on dental caries prevalence. Community Dentistry

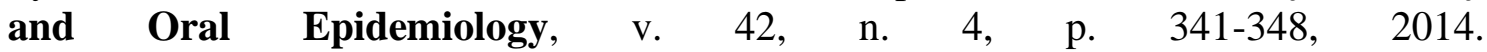
https://doi.org/10.1111/cdoe.12091

DE BRITO, C. S.; GARBIN, R. R.; MUSSI, A.; RIGO, L. Vigilância da concentração de flúor nas águas de abastecimento público na cidade de Passo Fundo - RS. Cadernos Saúde Coletiva, v. 24, n. 4, p. 452-459, 2016. https://doi.org/10.1590/1414-462x201600040240

DO CARMO, C. D. S.; ALES, C. M. C.; CAVALCANTE, P. R.; RIBEIRO, C. C. C. Avaliação da fluoretação da água do sistema de abastecimento público na Ilha de São Luís, Maranhão, Brasil. Ciência \& Saúde Coletiva, v. 15, supl. 1, p. 1835-1840, 2010. https://doi.org/10.1590/S1413-81232010000700096

DOVIDAUSKAS, S.; OKADA, I. A.; IHA, H.; CAVALLINI, A. G.; OKADA, M. M.; BRIGANTI, R. C. Avaliação da qualidade da fluoretação de águas de abastecimento público em 88 municípios da região Nordeste do estado de São Paulo (Brasil). Vigilância Sanitária em Debate, v. 5, n. 3, p. 14- 23, 2017. https://doi.org/10.22239/2317-269x.00926

DOVIDAUSKAS, S.; OKADA, I. A.; OKADA, M. M.; BRIGANTI, R. C.; DE OLIVEIRA, C. C. Determinação de fluoreto em baixas concentrações: validação de método com eletrodo íon seletivo para análise da água utilizada na preparação de soluções de diálise. Revista do Instituto Adolfo Lutz, v. 74, n. 4. p. 347-360, 2016. 
FERREIRA, R.; BENEDET, H.D. Comparação de métodos para determinação de flúor. Boletim do Centro de Pesquisa e Processamento de Alimentos, v. 17, n. 1, p. 53-58, 1999.

FRAZÃO, P.; ELY, H. C.; NORO, L. R. A.; PINHEIRO, H. H. C.; CURY, J. A. O modelo de vigilância da água e a divulgação de indicadores de concentração de fluoreto. Saúde em Debate, v. 42, n. 116, p. 274-286, 2018. https://doi.org/10.1590/0103-1104201811622

FRAZÃO, P.; PERES, M. A. P.; CURY, J. A. Drinking water quality and fluoride concentration. Revista de Saúde Pública, v. 45, n. 5, p. 964-73, 2011. https://doi.org/10.1590/S0034-89102011005000046

IBGE. Censo demográfico do município de Uberlândia, Minas Gerais, Brasil. Available at http://cidades.ibge.gov.br/xtras/perfil.php?codmun=317020. Access on 26 May 2020.

INSTITUTO TRATA BRASIL. Relatório Ranking do Saneamento. Instituto Trata Brasil 2016. Available at http://portaldoamazonas.com/wp-content/uploads/2016/04/relatoriocompleto.pdf. Access on 26 May 2020.

JORDAN, R. A.; SCHULTE, A.; BOCKELBRINK, A. C.; NAUMOVA, S. P. E.; WÄRN, L. G.; ZIMMER, S. Caries-Preventive Effect of Salt Fluoridation in Preschool Children in The Gambia: A Prospective, Controlled, Interventional Study. Caries Research. v. 51, n. 6, p. 596- 604, 2017. https://doi.org/10.1159/000479892

LARSON, R.; FARBER, B. Estatística Aplicada. 6. ed. São Paulo: Pearson Prentice Hall, 2016.

LEIVAS, L. L.; TOVO, M. F.; ARDENGHI, T. M.; FELDENS, C. A.; KRAMER, P. F.; FARACO JUNIOR, I. M. Heterocontrole da fluoretação das águas de abastecimento público do Município de Canoas/RS. Stomatos, v. 16, n. 30, p. 11-20, 2010.

LIMA, F. G.; LUND, R. G.; JUSTINO, L. M.; DEMARCO, F. F.; DEL PINO, F. A. B.; FERREIRA, R. Vinte e quatro meses de heterocontrole da fluoretação das águas de abastecimento público de Pelotas, Rio Grande do Sul, Brasil. Cadernos de Saúde $\begin{array}{lllllll}\text { Pública, } & \text { v. } & 20, & \text { n. } & 2, & \text { p. } & 422-429,\end{array}$ https://doi.org/10.1590/S0102-311X2004000200009

LINS-CANDEIRO, C. L. Monitoramento de fluoreto nas águas de abastecimento público: comparação entre a técnica eletrométrica e a colorimétrica. 2018. 26 f. Monografia (Graduação em Odontologia) - Universidade Federal de Uberlândia, Uberlândia, 2018.

MAIA, L. C.; VALENÇA, A. M. G.; SOARES, E. L.; CURY, J. A. Controle operacional da fluoretação da água de Niterói, Rio de Janeiro, Brasil. Cadernos de Saúde Pública, v. 19, n. 1, p. 61-67, 2003. https://doi.org/10.1590/s0102-311x2003000100007

MOIMAZ, S. A. S.; GARBIN, C. A. S; IGLESIAS, G. F.; CHIBA, F. Y.; SUMIDA, D. H.; SALIBA, O. Dificuldades enfrentadas no processo de fluoretação das águas de abastecimento público. Revista Brasileira de Pesquisa em Saúde, v. 17, n. 1, p. 87-94, 2015.

MOIMAZ, S. A. S.; SALIBA, O.; CHIBA, F. Y.; SUMIDA, D. H.; GARBIN, C. A. S.; SALIBA, N. A. Fluoride Concentration in Public Water Supply: 72 Months of Analysis. Brazilian Dental Journal, v. 23, n. 4, p. 451-456, 2012. https://doi.org/10.1590/S010364402012000400024 
MOTTER, J.; MOYSES, S. T.; FRANÇA, B. H. S.; CARVALHO, M. L.; MOYSÉS, S. J. Análise da concentração de flúor na água em Curitiba, Brasil: comparação entre técnicas. Revista Panamericana de Saúde Pública, v. 29, n. 2, p. 120-125, 2011. https://doi.org/10.1590/s1020-49892011000200007

NARVAI, P. C. Cárie dentária e flúor: uma relação do século XX. Ciência \& Saúde Coletiva, v. 5, n. 2, p. 381-392, 2000. https://doi.org/10.1590/S1413-81232000000200011

OLIVATI, F. N.; SOUZA, M. L. R.; TENUTA, L. M. A.; CURY, J. A. Quality of drinking water fluoridation of Capão Bonito, SP, Brazil, evaluated by operational and external controls. Revista Odonto Ciência v. 26, n. 4, p. 285-290, 2011. https://doi.org/10.1590/S1980-65232011000400002

PAREDES, S. O.; SAMPAIO, F. C.; FORTE, F. D. S. External Control over Fluoridation of the Public Water Supply in São Luís, MA, Brazil. Brazilian Research in Pediatric Dentistry and Integrated Clinic, v. 14, v. 2, p. 129-40, 2014. http://dx.doi.org/10.4034/PBOCI.2014.142.07

PETERSEN, P. E.; LENNON, M. A. Effective use of fluorides for the prevention of dental caries in the 21st century: the WHO approach. Community Dentistry and Oral Epidemiology, v. 32, n. 5, p. 319-321, 2004. https://doi.org/10.1111/j.16000528.2004.00175.x

PIORUNNECK, C. M. O.; DITTERICH, R. G.; GOMES, E. C. Heterocontrole da fluoretação nos municípios da região Metropolitana de Curitiba nos anos de 2014 e 2015. Cadernos Saúde Coletiva, v. 25 n. 4, p. 414-422, 2017. http://dx.doi.org/10.1590/1414462x201700040171

PRASAD, N.; PUSHPAANGAELI, B.; RAM, A.; MAIMANUKU, L. Fluoride concentration in drinking water samples in Fiji. Australian and New Zealand Journal of Public Health, v. 42, n. 4, p. 372-374, 2018. https://doi.org/10.1111/1753-6405.12787

RAMIRES, I.; BUZALAF, M. A. R. A fluoretação da água de abastecimento público e seus benefícios no controle da cárie dentária: cinquenta anos no Brasil. Ciência \& Saúde Coletiva v. 12, n. 4 , p. $1057-1065$, 2007. https://doi.org/10.1590/S141381232007000400027

UCHIDA, T. H.; CURY, J. A.; TABCHOURY, C. O. M.; TERADA, R. S. S.; FUJIMAKI, M. Heterocontrole da fluoretação da água de abastecimento público da $15^{\mathrm{a}}$ Regional de Saúde do Paraná. Revista de Saúde Pública. v. 1, n. 1, p. 59-67, 2018. https://doi.org/10.32811/2595-4482.2018v1n1.40

VON ELM, E.; ALTMAN, D. G.; EGGER, M.; POCOCK, S. J.; GOTZSCHE, P. C.; VANDERBROUCKE, J. P. The Strengthening the Reporting of Observational Studies in Epidemiology (STROBE) Statement: Guidelines for Reporting Observational Studies. Journal of Clinical Epidemiology, v. 61, n. 4, p. 344-349, 2008. https://doi.org/10.1016/j.jclinepi.2007.11.008

ZIMMER, S.; JAHN, K. R.; BARTHEL, C. R. Recommendations for the use of fluoride in caries prevention. Oral Health \& Preventive Dentistry. v. 1, n. 1, p. 45-51, 2003. 


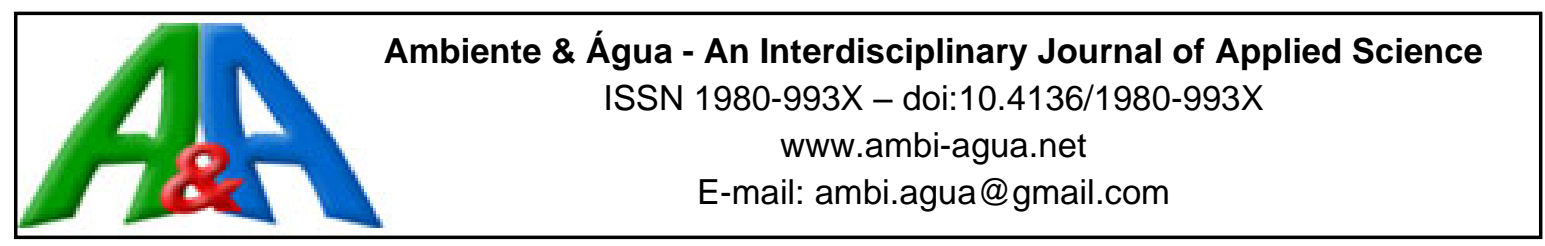

\title{
Coagulation Activity of the Seed Extract from Zygia cauliflora (WILLD.) KILLIP applied in Water Treatment
}

\author{
ARTICLES doi:10.4136/ambi-agua.2611
}

Received: 29 Jun. 2020; Accepted: 28 Sep. 2020

\begin{abstract}
Julia Aoki Domingues ${ }^{1}$; Nelson Consolin Filho ${ }^{2 *}$;
Luiz Augusto Gomes de Souza ${ }^{3}$; Flávia Vieira da Silva Medeiros ${ }^{1}$ (D)
${ }^{1}$ Departamento de Engenharia Ambiental. Universidade Tecnológica Federal do Paraná (UTFPR), Via Rosalina Maria dos Santos, n 1233, CEP: 87301-899, Campo Mourão, PR, Brazil.
E-mail: juaoki12@gmail.com, flaviav@utfpr.edu.br
${ }^{2}$ Departamento de Química. Universidade Tecnológica Federal do Paraná (UTFPR), Via Rosalina Maria dos Santos, $\mathrm{n}^{\circ}$ 1233, CEP: 87301-899, Campo Mourão, PR, Brazil.

${ }^{3}$ Departamento de Ciências Agronômicas. Instituto Nacional de Pesquisas da Amazônia (INPA), Avenida André Araújo, n² 2936, CEP: 69083-000, Manaus, AM, Brazil. E-mail: souzalag@inpa.gov.br

*Corresponding author. E-mail: consolin@utfpr.edu.br
\end{abstract}

\begin{abstract}
The use of natural coagulants is a promising alternative to replace or assist chemical coagulants due to its numerous advantages. This paper evaluates the effectiveness of a natural coagulant in water treatment. The coagulant was extracted from the Zygia cauliflora (Willd.) Killip seed in saline solutions and defatted using $95 \%$ ethanol. The tests were conducted using different concentrations of the coagulant $\left(0.1,0.5,1.0,2.0,3.0\right.$, and $\left.4.0 \mathrm{~g} \mathrm{~L}^{-1}\right)$ and of $\mathrm{NaCl}(0.0$ $\mathrm{M}, 1.0 \mathrm{M}$, and $5.0 \mathrm{M})$. The results showed that the use of $2 \mathrm{~g} \mathrm{~L}^{-1}$ of coagulant and $1.0 \mathrm{M}$ of the salt achieved an effectiveness of $20 \%$ and $70 \%$, respectively, of color and turbidity removal. The analysis showed an effectiveness of $70 \%$ and $30 \%$, respectively, when removing the $\mathrm{UV}_{254}$ compound and DOM (dissolved organic matter). The mechanism for turbidity removal by the coagulants prepared with aqueous solution and with saline solution at $1.0 \mathrm{M}$ of $\mathrm{NaCl}$ is supposed to be adsorption and charge neutralization, respectively, following the Freundlich and Langmuir models. However, the coagulant prepared with saline solution at $5.0 \mathrm{M}$ of $\mathrm{NaCl}$ tends to form a netlike structure followed by turbidity removal through a sweep coagulation mechanism. Future papers should therefore focus on the use of Zygia cauliflora (Willd.) Killip as an alternative for replacement or use as an auxiliary chemical coagulant.
\end{abstract}

Keywords: Amazon seed, flocculation, natural coagulant.

\section{Atividade Coagulante do Extrato de Sementes de Zygia cauliflora (WILLD.) KILLIP no Tratamento de Água}

\section{RESUMO}

O uso de coagulantes naturais é uma alternativa promissora para substituir ou auxiliar coagulantes químicos devido às suas inúmeras vantagens. Este artigo avalia a eficácia no uso de um coagulante natural no tratamento de água. O coagulante foi extraído da semente de Killip Zygia cauliflora (Willd.) em soluções salinas e desengordurada com etanol a 95\%. Os testes foram conduzidos utilizando diferentes concentrações do coagulante $(0,1,0,5,1,0,2,0,3,0$ e 
4,0 $\left.\mathrm{g} \mathrm{L}^{-1}\right)$ e de $\mathrm{NaCl}\left(0,0 \mathrm{M}, 1,0 \mathrm{M}\right.$ e 5,0 M). Os resultados mostraram que o uso de $2 \mathrm{~g} \mathrm{~L}^{-1}$ de coagulante e 1,0 M de sal alcançou uma eficácia de $20 \%$ e $70 \%$, respectivamente, na remoção de cor e turbidez. A análise mostrou uma eficácia de $70 \%$ e $30 \%$, respectivamente, na remoção do composto UV254 e DOM (matéria orgânica dissolvida). Além disso, o mecanismo de remoção da turbidez pelos coagulantes preparados com solução aquosa e com solução salina a 1,0 M de $\mathrm{NaCl}$ é suposto ser adsorção e neutralização de carga, respectivamente seguindo os modelos de Freundlich e Langmuir. No entanto, o coagulante preparado com solução salina a 5,0 M de $\mathrm{NaCl}$ tende a formar uma estrutura semelhante a uma rede seguida pela remoção da turbidez por mecanismo de coagulação por varredura. Portanto, trabalhos futuros devem se concentrar no uso de Zygia cauliflora (Willd.) Killip como uma alternativa para substituição ou uso como coagulante químico auxiliar.

Palavras-chave: coagulante natural, floculação, semente da Amazônia.

\section{INTRODUCTION}

According to the World Health Organization (WHO) and its member countries, "every person, at any stage of development and socio-economic conditions, has the right to access an adequate supply of potable and safe water'. In this context, 'safe' refers to a water supply which does not represent a health risk, with enough quantity to meet all household needs, that is continuously available, and is affordable. If the purpose is to improve public health, such conditions must be considered when defining and maintaining water quality and water supply programs (OPS, 2001).

During the water treatment process, one of the first steps is coagulation, which aims to reduce impurities to make the water potable. Since it is a delicate part of the treatment, a strict control of the dosage of these chemical products is necessary. However, an increase of these dosages is required considering the high demand of potable water and a considerable decrease in the quality of water resources. The decision of coagulant is often based on economic factors, related to suitability, raw water, treatment technology, and cost (Richter et al., 1991).

According to Richter (2009), the most commonly used coagulants are iron and aluminumbased coagulants, due to their reaction with the natural alkalinity of raw water. According to several studies, there is evidence of a relationship between the content of aluminum in treated water and the increasing incidents of neurological diseases. According to Flaten (2001), aluminum plays an important role in the etiology and pathogenesis of Alzheimer's, but this connection is still under debate. Bondy (2010) states that there are analyses that link Parkinson's disease and other chronic neurodegenerative diseases as well.

Moreover, the high sensitivity of inorganic coagulants to the water $\mathrm{pH}$ and the possibility of secondary contamination of drinking water with traces of toxic synthetic polymeric coagulants or residual iron and aluminum ions are the main challenges for flocculationcoagulation water treatment processes (Bratskaya et al., 2004).

In view of these disadvantages, it is desirable to replace chemical coagulants with natural coagulants. Using natural plants as coagulants has many advantages, among which are their profitability, biodegradability, and lack of requirement for a high $\mathrm{pH}$ for water treatment (Bratskaya et al., 2004).

Thus, the Moringa oleifera Lam (moringa) seed has been gaining prominence as a natural coagulant in water treatment since the species contains an edible oil, a water-soluble substance with protein in its organic composition, and can act as an effective coagulant Salazer Gámez et al., 2015). However, Moringa oleifera is an Indian seed, so its availability could be restrictive for water treatment worldwide. It is therefore important to research the applicability of regional leguminous seeds that could play the same role as Moringa oleifera Lam. 
Many plants have recently been identified as sources of natural polymers for the treatment of various types of water, including Plantago ovata, Musa ABB, and Strychnos potatorum (Ramavandi, 2014; Tirado et al., 2017; Gaikwad and Munavalli, 2019).

The use of regional coagulants is studied to evaluate their applicability regarding the difference in coagulation capacity, cheapness, variety, and ease of access. This research has attempted to use Zygia cauliflora (Willd.) Killip. seeds as an abundantly available, low-cost, and renewable precursor for producing a coagulant for improving water quality. Zygia cauliflora (Willd.) Killip. was considered because it is one of the most abundant species in undisturbed forests and with the highest density throughout the Amazon rainforest, especially in permanent preservation areas of the Moju River Basin (Oliveira et al., 2016). Zygia cauliflora (Willd.) Killip. trees, flowers and seeds are shown in Figure 1.

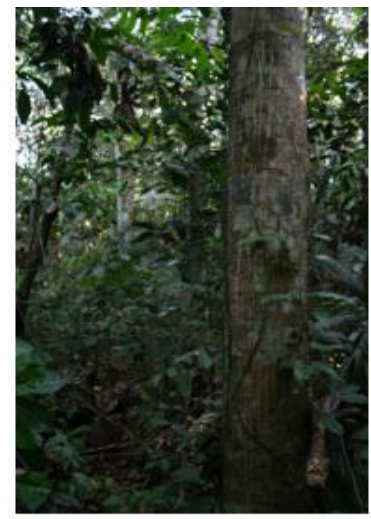

(a)

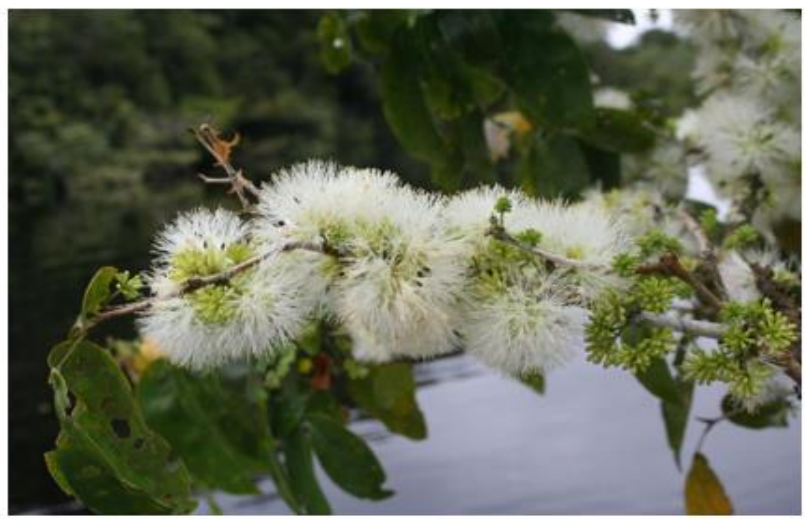

(b)

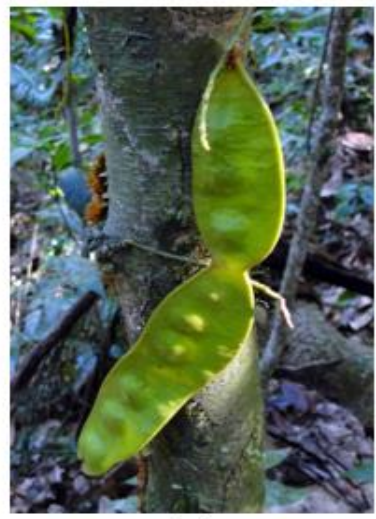

(c)

Figure 1. Zygia cauliflora (Willd.) Killip. tree (a), flowers (b) and seeds (c).

Therefore, this paper evaluates the coagulation potential of aqueous and saline solutions obtained from Zygia cauliflora (Willd.) Killip. seeds to determine water color, turbidity, and organic compounds absorbed at $254 \mathrm{~nm}$ ( $\mathrm{UV}_{254}$ compounds) and to remove dissolved organic matter (DOM). The effect of the operational parameters including coagulant dosage and $\mathrm{NaCl}$ concentration was studied to better understand the coagulation process using Zygia cauliflora (Willd.) Killip. seeds.

\section{MATERIALS AND METHODS}

Raw water samples were collected from a public water treatment system (WTS), Paraná Sanitation Company (Companhia de Saneamento do Paraná, SANEPAR), located in Campo Mourão, State of Paraná, Brazil. The surface water originates from the Campo River Basin.

Characterization before and after the treatment was carried out using quality parameters such as color, turbidity, $\mathrm{UV}_{254}$, and dissolved organic matter (DOM). 


\subsection{Color}

The apparent color was determined based on the procedures described in Standard Methods for the Examination of Water and Wastewater ${ }^{10}$ using the Digimed colorimeter equipment, Model DM-COR.

\subsection{Turbidity}

The turbidity was determined based on the procedures described in Standard Methods for the Examination of Water and Wastewater (APHA et al., 2012) using a turbidimeter (PoliControl equipment, Model AP2000 iR).

\subsection{Dissolved organic matter parameters}

The $\mathrm{UV}_{254}$ and $\mathrm{UV}_{272}$ compounds were determined using the $\mathrm{HACH}$ spectrophotometer, Model DR5000.

Equation 1 was used to determine the concentration of dissolved organic matter from $\mathrm{UV}_{272}$ results, a method proposed previously (Khan et al., 2014).

$$
\operatorname{DOM}\left(\mathrm{mg} \mathrm{L}^{-1}\right)=518.93 \times \text { Absorbance }(272 \mathrm{~nm})+1.065
$$

The detection of dissolved organic matter (DOM) in water is necessary since it consists of a set of substances originated from the excretion, secretion, and intermediary process of the decomposition of terrestrial and aquatic organisms (Di Bernardo et al., 2002), which influences water appearance among other consequences.

\subsection{Extraction and preparation of the coagulant}

The method used for the extraction and preparation of the coagulant in saline solution was described by Sánchez-Martín et al. (2010).

The peels of the Zygia cauliflora (Willd.) Killip seeds were manually removed and ground in a domestic blender. The powder was defatted in $95 \%$ ethanol with a mass/volume ratio of 1:10 using a magnetic stirrer for 45 minutes at $150 \mathrm{rpm}$.

The supernatant was manually separated and placed in glass tubes so that the resulting powder would dry in an oven at $60^{\circ} \mathrm{C}$ for three days.

A coagulant was prepared in distilled water, which was denominated aqueous solution. One gram of the dried seed was added in a glass beaker containing $0.1 \mathrm{~L}$. The coagulant was extracted by turbolysis for 3 minutes and then stirred in a magnetic stirrer for 30 minutes at 150 $\mathrm{rpm}$. The obtained solution was vacuum filtrated on quality filter paper and then on a $0.9 \mu \mathrm{m}$ pore glass fiber membrane. The dried seeds and turbolysis process are shown in Figure 2.

The same procedure was performed for the saline solutions of $1 \mathrm{M}$ and $5 \mathrm{M}$.

All tests were performed in duplicate.
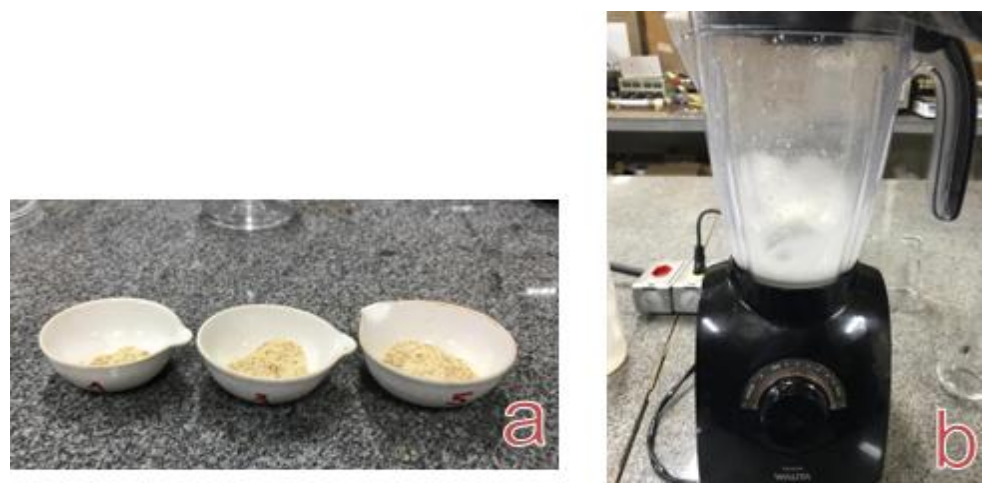

Figure 2. Dried seeds (a) and turbolysis process (b). 


\subsection{Coagulation/flocculation test}

The coagulation/flocculation tests were performed on a Jar test device (Nova Ética) with a rotating regulator of mixing rods and jars with capacity of $1 \mathrm{~L}$ (Figure 3 ).

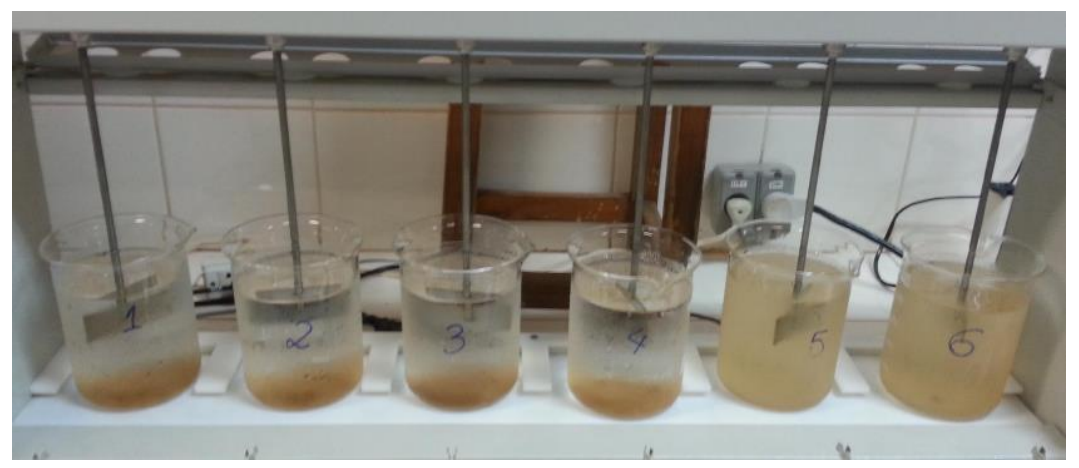

Figure 3. Coagulation/flocculation performed on Jar test equipment.

The use of the Jar Test allows the determination of the ideal dosage of coagulant or coagulation aid necessary to cause raw water clarification (Di Bernardo et al., 2002).

Predetermined amounts of coagulant solution were added to each jar (Table 1), using an automatic pipette. The water used was at room temperature, without any $\mathrm{pH}$ correction or adjustment.

Table 1. Coagulant concentration solution in each jar.

\begin{tabular}{lcccccc}
\hline & Jar 1 & Jar 2 & Jar 3 & Jar 4 & Jar 5 & Jar 6 \\
\hline Coagulant concentration $\left(\mathrm{mg} \mathrm{L}^{-1}\right)$ & 0.1 & 0.5 & 1.0 & 2.0 & 3.0 & 4.0 \\
\hline
\end{tabular}

The rapid mixing was set at 1 minute, with gradient speed of $120 \mathrm{rpm}$, while the slow mixing was set at 15 minutes at $60 \mathrm{rpm}$. The settling time was established at 15 minutes. The methodology used for the tests was described in Di Bernardo et al. (2002).

Subsequently, the color, turbidity, $\mathrm{UV}_{254}$ compounds, and DOM were measured to verify the efficiency of the process by comparing the results with raw water.

\subsection{Mechanism evaluation}

In order to evaluate the mechanism of coagulation/flocculation process using aqueous and saline solutions obtained from Zygia cauliflora (Willd.) Killip, Langmuir and Freundlich isotherms were employed to describe adsorption equilibrium. This evaluation was performed using turbidity removal data and was adapted from Fahmi et al. (2011), Mateus et al. (2020), Zhou et al. (2018) and Sia et al. (2020).

The theoretically derived Langmuir model assumes adsorption energies are uniform and independent of surface coverage and complete coverage of surface by a monolayer of adsorbate indicates maximum adsorption. The linear form of Langmuir isotherm is given in Equation 2:

$\frac{1}{q_{e}}=\frac{1}{q_{m}}+\frac{1}{q_{m} K_{l} C_{e}}$

Where:

$\mathrm{q}_{\mathrm{e}}=$ ratio of turbidity adsorbed to the dosage of coagulant employed

$\mathrm{C}_{\mathrm{e}}=$ equilibrium concentration of turbidity

$\mathrm{q}_{\mathrm{m}}=$ maximum adsorption capacity of the coagulant employed

$\mathrm{K}_{\mathrm{l}}=$ Langmuir constant, related to the energy of adsorption 
The value of Langmuir constants (slope) and maximum adsorption capacity (intercept) were obtained from the linear correlation plots between $1 / q_{\mathrm{e}}$ with $1 / \mathrm{C}_{\mathrm{e}}$.

On the other hand, the Freundlich model is empirical, encompassing the heterogeneity of adsorbent surface, the exponential distribution sites and their energies. The linear equation of the Freundlich isotherm is given in Equation 3:

$l q_{e}=l K_{f}+\frac{1}{n} l C_{e}$

Where:

$\mathrm{q}_{\mathrm{e}}=$ ratio of turbidity adsorbed to the dosage of coagulant employed

$\mathrm{C}_{\mathrm{e}}=$ equilibrium concentration of turbidity

$\mathrm{K}_{\mathrm{f}}=$ Freundlich constant indicative of the relative adsorption capacity of the adsorbent

$1 / \mathrm{n}=$ constant that indicates the adsorption intensity

The value of Freundlich constants (slope) and adsorption intensity (intercept) were obtained from the linear correlation plots between $\ln \mathrm{q}_{\mathrm{e}}$ with $\ln \mathrm{C}_{\mathrm{e}}$.

\section{RESULTS AND DISCUSSION}

\subsection{Characterization of the raw water}

The results of the raw water characterizations are presented in Table 2 according to color, turbidity, $\mathrm{UV}_{254}$ compounds, and DOM.

Table 2. Results of the physical-chemical analysis of the raw water.

\begin{tabular}{cc}
\hline & Raw water \\
\hline Color (uH) & 92.2 \\
Turbidity (NTU) & 76.3 \\
$\mathrm{UV}_{254}(\mathrm{abs})$ & 1.367 \\
DOM $\left(\mathrm{mg} \mathrm{L}^{-1}\right)$ & $1,183.2$ \\
\hline
\end{tabular}

According to Gaikwad et al. (2019), the composition of typical raw water samples collected from a river has a turbidity of 5-50 NTU. The turbidity of the raw water collected in this study was 76.3 NTU, which can be considered high.

On the other hand, the raw water characteristics are similar to reports found in literature. Ramavandi (2014) evaluated a coagulant extracted from Platago ovata and used a raw water with turbidity of $76 \mathrm{NTU}$, TOC (total organic carbon) of $8.6 \mathrm{mg} \mathrm{L}^{-1}$ and DOC of $4.02 \mathrm{mg} \mathrm{L}^{-1} .8$ Lima et al. (2017) used raw water with color of 174 UC and turbidity of 97 NTU when studying Abelmoschus esculentus as a flocculation aid. Malik (2018) used raw water with higher levels of turbidity, 250 NTU.

\subsection{Results of the tests with Zygia cauliflora (Willd.) Killip as a potential natural coagulant}

Figure 4 presents the results of color, turbidity, $\mathrm{UV}_{254 \mathrm{~nm}}$ absorption compounds, and DOM removal obtained with the coagulants prepared from Zygia cauliflora (Willd.) Killip in different dosages and different concentrations of $\mathrm{NaCl}$. The results with saline solutions were similar, showing no considerable variations between 1.0 M and 5.0 M solutions. The results of removing 
the color, turbidity, and $\mathrm{UV}_{254}$ were approximately $20 \%, 70 \%$, and $70 \%$, respectively, with no considerable differences between the dosage employed. Despite this, the coagulant prepared with $5.0 \mathrm{M}$ of $\mathrm{NaCl}$ removed no DOM at any dosage, while the coagulant prepared with $1.0 \mathrm{M}$ of $\mathrm{NaCl}$ removed approximately $21 \%$ of DOM at all dosages.

On the other hand, the coagulant obtained from the aqueous solution removed no color, while removing turbidity, $\mathrm{UV}_{254}$, and DOM at approximately $45 \%, 70 \%$, and 30\%, respectively.

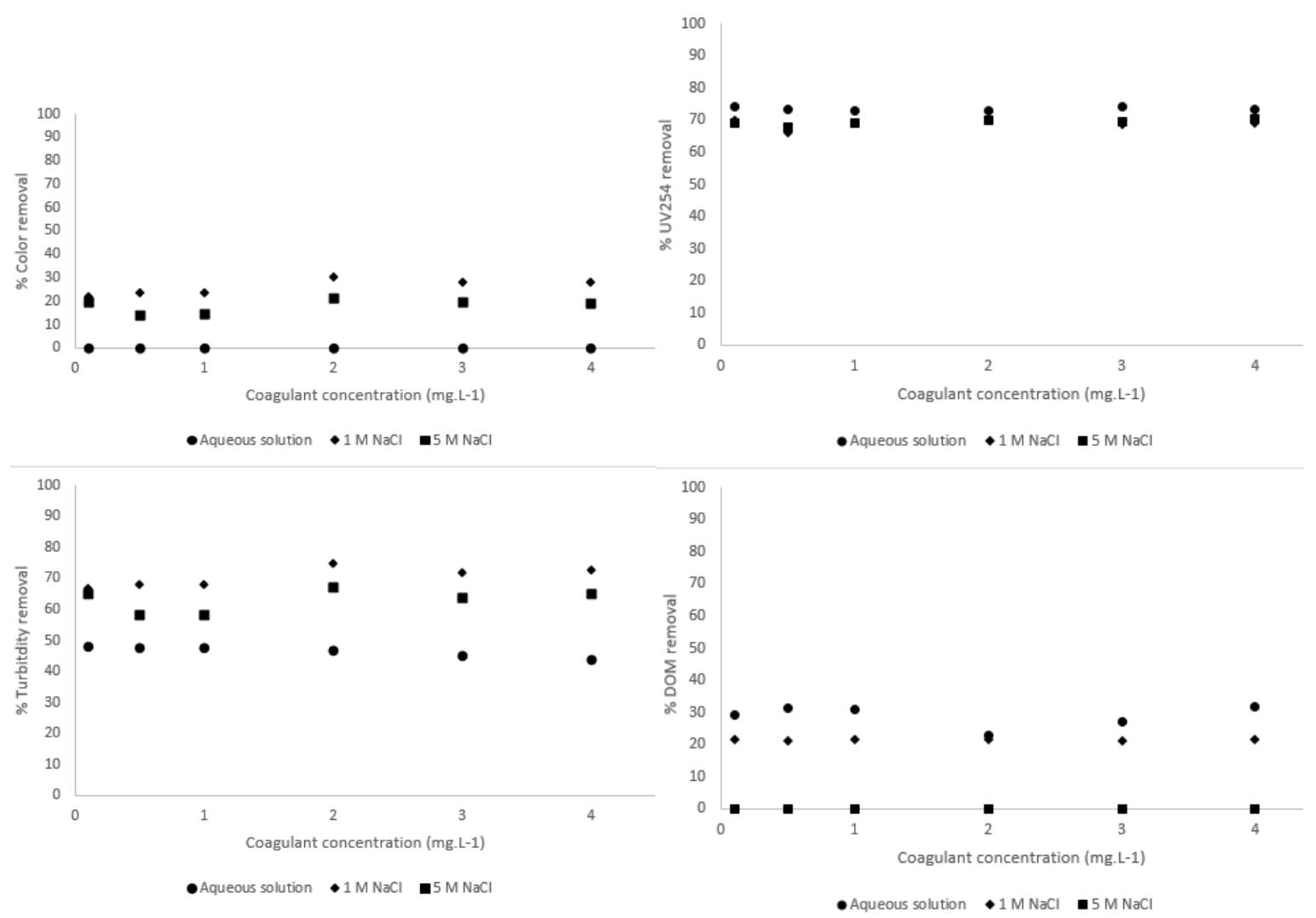

Figure 4. Efficiency of removal of parameters using different dosages of coagulants prepared from Zygia cauliflora (Willd.) Killip.

Considering these results, the coagulants prepared with a saline solution at $1.0 \mathrm{M}$ of $\mathrm{NaCl}$ were more efficient than those prepared with a $5.0 \mathrm{M}$ solution. Furthermore, better results were obtained for the coagulant concentration of $2 \mathrm{~g} \mathrm{~L}^{-1}$, even when compared to concentrations of $3 \mathrm{~g} \mathrm{~L}^{-1}$ and $4 \mathrm{~g} \mathrm{~L}^{-1}$, which also showed reasonable results of color and turbidity removal. Thus, a more satisfactory efficiency was obtained for the saline solution with $1.0 \mathrm{M}$ concentration of $\mathrm{NaCl}$ for the analyzed parameters, presenting $30.4 \%$ and $74.5 \%$ of removal, respectively, for color and turbidity.

Moreover, the saline solutions presented greater efficiency in removing color and turbidity when compared with the aqueous solution, as observed by Madrona et al. (2010), Nkurunziza et al. (2009), and Nishi et al. (2011).

Nkurunziza et al. (2009) reached $99.8 \%$ of turbidity removal using Moringa oleifera coagulant extracted with saline solution at $1.0 \mathrm{M}$, while Nishi et al. (2011) obtained $96.4 \%$ of color removal in the same conditions. These results suggest that Zygia cauliflora (Willd.) Killip could be applied as a coagulation/flocculation aid, instead of a primary coagulant.

The aqueous solution presented better $\mathrm{UV}_{254}$ compound and DOM removal, removing $74.3 \%$ of $\mathrm{UV}_{254}$ compounds at the concentration of $3.0 \mathrm{mg} \cdot \mathrm{L}^{-1}$ and $31.7 \%$ of DOM at the concentration of $4.0 \mathrm{mg} \mathrm{L}^{-1}$.

The presence of $\mathrm{NaCl}$ in the water showed that increasing the ionic strength results in a greater amount of extracted compounds, but does not affect coagulation activity, which can be 
observed in the results of $U_{254}$ and DOM removal (Kukic et al. 2015).

Previous work found in the literature shows that the coagulant obtained from Plantago ovata at a dosage of $0.250 \mathrm{mg} \mathrm{L}^{-1}$ showed turbidity removal of $36 \%$ and $99 \%$, respectively, when using crude and treated extract (Ramavandi, 2014).

Tirado et al. (2017) applied higher dosages (5-200 $\mathrm{mg} \mathrm{L}^{-1}$ ) of starch obtained from Musa ABB as a coagulant and achieved color and turbidity removals from 90 to $99 \% .{ }^{9}$ The difference in results when compared to this work could be due to the higher dosages used by the authors.

Valverde et al. (2018) evaluated the synergistic effect between Moringa oleifera and APC (aluminum polychloride) for coagulation/flocculation and observed lower removal efficiencies at greater proportions of moringa, with $70.1 \%, 75.1 \%$, and $56.7 \%$ for color, turbidity, and $\mathrm{UV}_{254}$ absorption, respectively, which suggests that natural coagulants present lower removal efficiencies. Furthermore, Valverde et al. (2018) obtained a turbidity removal close to that observed in this work with the coagulant prepared with saline solutions, from 65 to $70 \%$. Moreover, the removal of $\mathrm{UV}_{254}$ compounds achieved in this paper are higher, at $70 \%$, for aqueous and saline solutions than the results observed by Valverde et al. (2018), even though the authors employed a synthetic coagulant in association with Moringa oleifera.

\subsection{Mechanism evaluation results}

Figures 5 and 6 show the respective results of Langmuir and Freundlich adsorption equilibrium models for turbidity removal, and Table 3 presents the $\mathrm{R}^{2}$ obtained for each model and coagulant condition.

It was observed that the coagulants prepared with aqueous solution and with a saline solution at $1.0 \mathrm{M}$ of $\mathrm{NaCl}$ show positive correlation with Langmuir and Freundlich models. The coagulant prepared in aqueous solution presented $\mathrm{R}^{2}$ of 0.77 and 0.98 , respectively, for the Langmuir and Freundlich models, while the coagulant prepared with a saline solution at $1.0 \mathrm{M}$ of $\mathrm{NaCl}$ showed $\mathrm{R}^{2}$ of 0.63 for and 0.54 , respectively, for the Langmuir and Freundlich models. This indicates that adsorption and charge neutralization mechanisms are most likely involved in the processes (Fahmi et al., 2011).
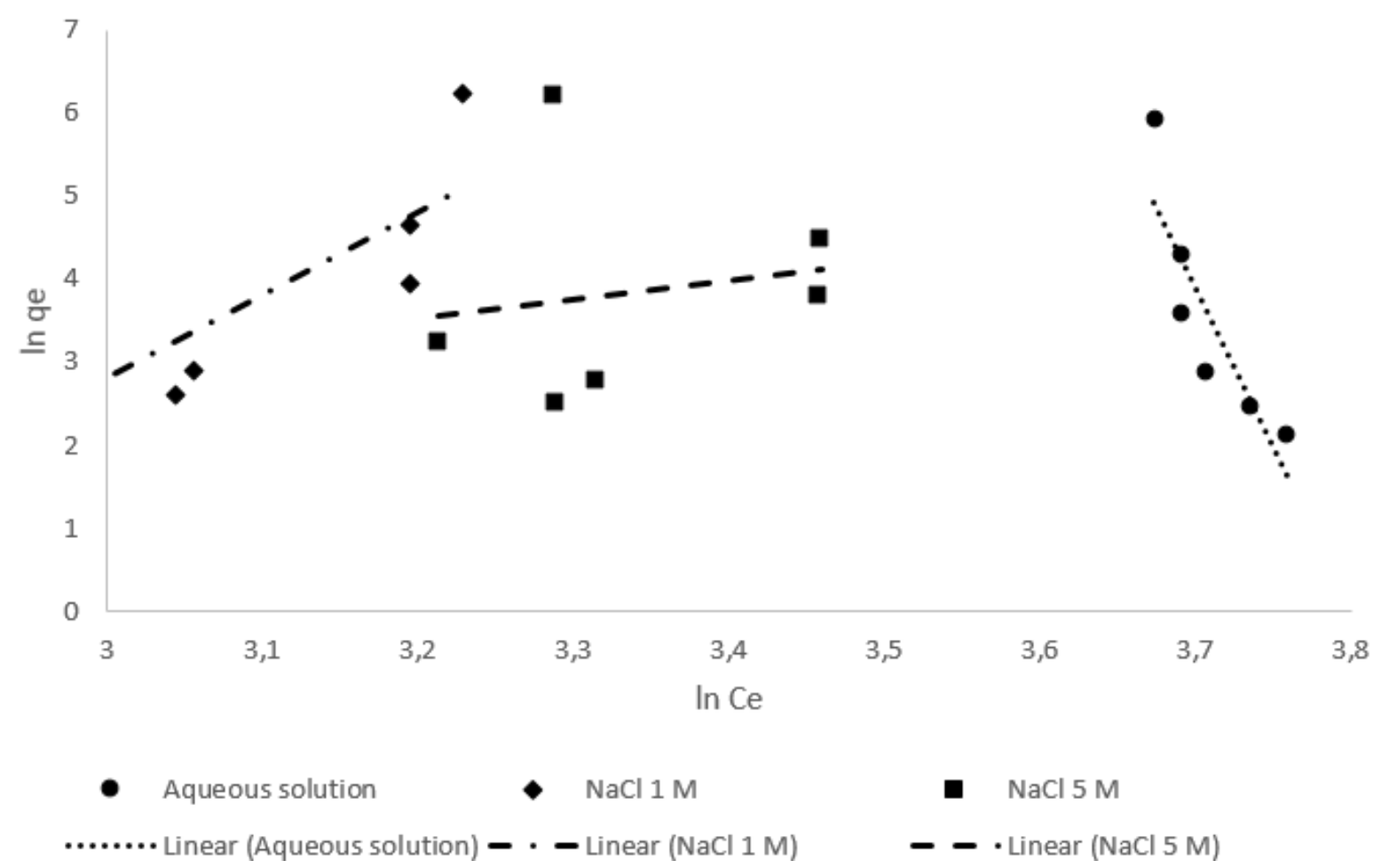

Figure 5. Langmuir adsorption isotherm for turbidity removal. 


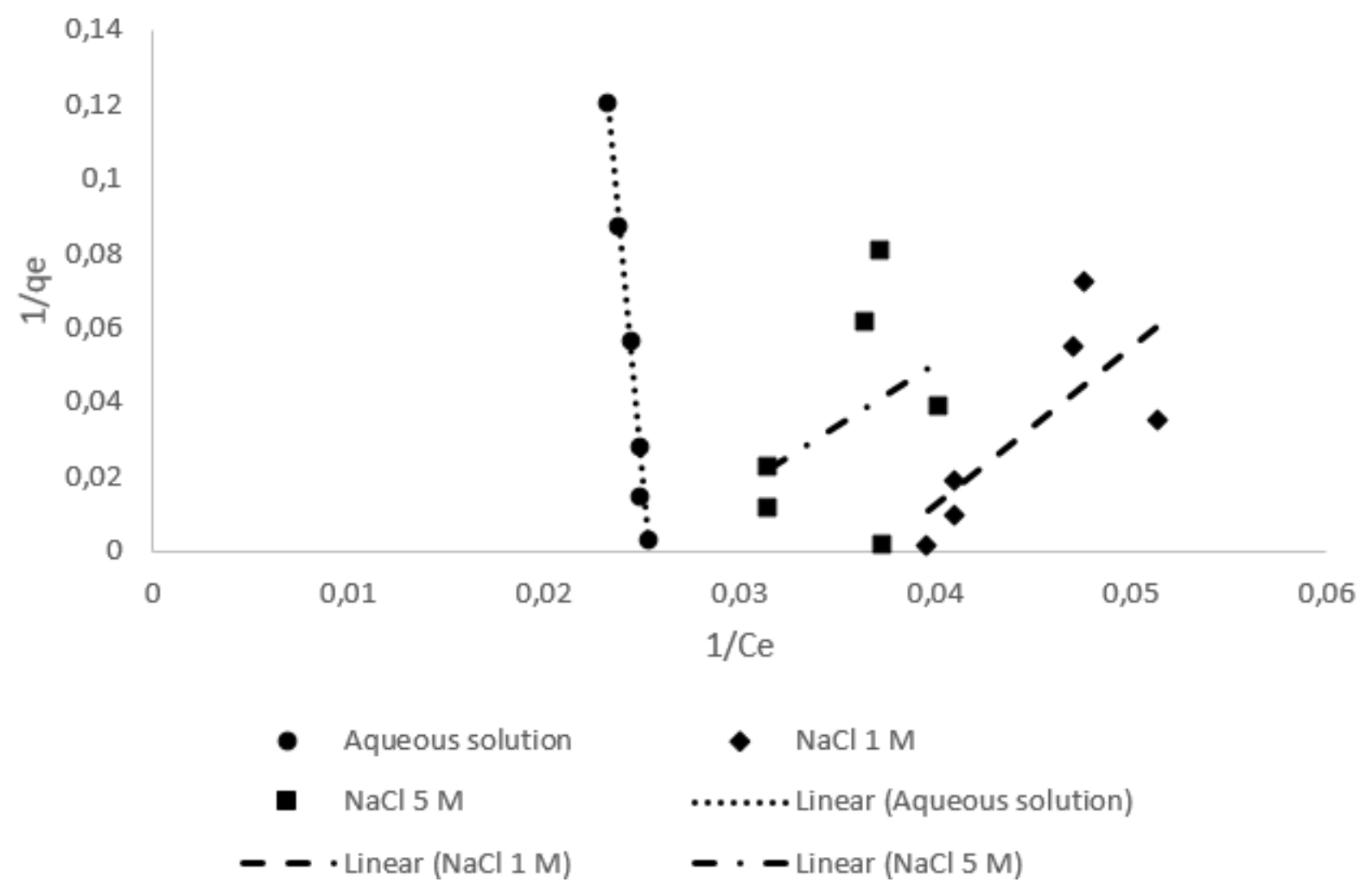

Figure 6. Freundlich adsorption isotherm for turbidity removal.

Table 3. $\mathrm{R}^{2}$ results for Langmuir and Freundlich models applied to turbidity removal.

\begin{tabular}{ccc}
\hline Coagulant condition & $\mathbf{R}^{\mathbf{2}}$ (Langmuir) & $\mathbf{R}^{\mathbf{2}}$ (Freundlich) \\
\hline Aqueous solution & 0.77 & 0.98 \\
$\mathrm{NaCl} \mathrm{1} \mathrm{M}$ & 0.63 & 0.54 \\
$\mathrm{NaCl} \mathrm{5} \mathrm{M}$ & 0.03 & 0.15 \\
\hline
\end{tabular}

Furthermore, the mechanism for turbidity removal for the coagulant obtained from Zygia cauliflora (Willd.) Killip. Extract in aqueous solution was found to be due to adsorption, approximating to the Freundlich type $\left(>R^{2}\right)$, which indicates that adsorption occurs on heterogeneous surface and the adsorption energy decreases logarithmically, as the surface of adsorbent becomes covered by the solute (Fahmi et al., 2011; Mateus et al., 2020; Zhou et al., 2018; Sia et al., 2020).

With the experimental data presented, it is possible to observe that the Langmuir model presented a better fit $\left(>\mathrm{R}^{2}\right)$ for the coagulant with a saline solution at $1.0 \mathrm{M}$ of $\mathrm{NaCl}$, suggesting homogeneous and monolayer adsorption characterizing a more selective adsorption process, as reported by Mateus et al. (2020). The decay in $\mathrm{R}^{2}$ values when compared with aqueous solution suggests that the mechanisms involved tend to change when saline solution is used to extract the coagulant from Zygia cauliflora (Willd.) Killip. seeds.

However, these models were not found to fit for the coagulant prepared with a saline solution at $5.0 \mathrm{M}$ of $\mathrm{NaCl}$, which presented $\mathrm{R}^{2}$ for the Langmuir model of 0.03 and for the Freundlich model of 0.15. This occurrence indicates that the coagulant obtained from Zygia cauliflora (Willd.) Killip. at higher saline concentrations more probably form a netlike structure followed by turbidity removal through a sweep coagulation mechanism, as previously described (Fahmi et al., 2011). \\ IPABH}




\section{CONCLUSIONS}

This study showed that the concentration of $\mathrm{NaCl}$ slightly influenced the removal of water parameters such as color, turbidity, $\mathrm{UV}_{254}$ compounds, and DOM using the coagulants obtained from Zygia cauliflora (Willd.) Killip. The optimum dosage of coagulant for color and turbidity removal was $2.0 \mathrm{mg} \mathrm{L}^{-1}$ with $1.0 \mathrm{M} \mathrm{NaCl}$, which is very low and removed $21 \%$ of DOM from treated water. The removal of color, turbidity, $\mathrm{UV}_{254}$ compounds, and DOM were $30.4 \%$, $74.5 \%, 70.1 \%$, and $21.5 \%$, respectively, in this optimum dosage.

Furthermore, aqueous solution in concentrations of 3.0 and $4.0 \mathrm{mg} \mathrm{L}^{-1}$ removed $\mathrm{UV}_{254}$ compounds and DOM more efficiently, with values of $74.3 \%$ and $31.7 \%$, respectively.

Moreover, the mechanism for turbidity removal by the coagulants prepared with aqueous solution and with a saline solution at $1.0 \mathrm{M}$ of $\mathrm{NaCl}$ is supposed to be adsorption and charge neutralization, with the adsorption isotherm following the Freundlich model for aqueous solution and the Langmuir model for saline solution at $1.0 \mathrm{M}$ of $\mathrm{NaCl}$. Therefore, the coagulant prepared with a saline solution at $5.0 \mathrm{M}$ of $\mathrm{NaCl}$ tends to form a netlike structure followed by turbidity removal through sweep coagulation mechanism.

According to the data presented, the Zygia cauliflora (Willd.) Killip seed can be used as a natural coagulant and is a good alternative to improve water quality for human supply.

\section{REFERENCES}

APHA; AWWA; WEF. Standard Methods for the examination of water and wastewater. 22nd ed. Washington, 2012. 1496 p.

BONDY, S. C. The neurotoxicity of environmental aluminum is still an issue. $\begin{array}{lllllll}\text { NeuroToxicology, } & \text { v. } & 31, & \text { n. } & 5, & \text { p. } & 575-581,\end{array}$ https://doi.org/10.1016/j.neuro.2010.05.009

BRATSKAYA, S.; SCHWARTZ, S.; CHERVONETSKY, D. Comparative Study of Humic Acids Flocculation with Chitosan Hydrochloride and Chitosan Glutamate. Water Research, v. 38, p. 2955-2961, 2004. https://doi.org/10.1016/j.watres.2004.03.033

DI BERNARDO, L.; DI BERNARDO, A.; CENTURIONE FILHO, P. L. Ensaios de Tratabilidade de Água e Resíduos Gerados em Estações de Tratamento de Água. São Carlos: Rima, 2002.

FAHMI, M. R.; NAJIB, N. W. A.Z.; PING, P. C.; HAMIDIN, N. Mechanism of turbidity and hardness removal in hard water sources by using Moringa oleifera. Journal of Applied Sciences, v. 11, p. 2947-2953, 2011.

FLATEN, T. P. Aluminium as a risk factor in Alzheimer's disease, with emphasis on drinking water. Brain Research Bulletin, v. 55, n. 2, p. 187-196, 2001. https://doi.org/10.1016/S0361-9230(01)00459-2

GAIKWAD, V. T.; MUNAVALLI, G. R. Turbidity Removal by Conventional and Ballasted Coagulation with Natural Coagulants. Applied Water Science, v. 9, 2019. https://doi.org/10.1007/s13201-019-1009-6

KHAN, S.; YAOGUO, W.; XIAOYAN, Z.; JINGTAO, L.; JICHAO, S.; SIHAI, H.; Estimation of concentration of dissolved organic matter from sediment by using uv-visible spectrophotometer. International Journal of Environmental Pollution and Remediation, v. 2, p. 24-29, 2014. https://dx.doi.org/10.11159/ijepr.2014.004 
KUKIC, D. V.; SCIBAN, M. B.; PRODANOVIC, J. M.; TEPIC, A. N.; VASIC, M. A. Extracts of fava bean (Vicia faba L.) seeds as natural coagulants. Ecological Engineering, V. 84, p. 229-232, 2015. https://doi.org/10.1016/j.ecoleng.2015.09.008

LIMA, B. C.; PINGUELO, G. C. B.; VEMASQUI, L. G.; TEIXEIRA, G. G.; SILVA MEDEIROS, F. V. Influência do tempo de mistura lenta no uso de quiabo como floculante aplicado associado ao policloreto de alumínio. Brazilian Journal of Food Research, v. 8, n. 4, p. 13-22, 2017. http://dx.doi.org/10.3895/rebrapa.v8n4.4014

MADRONA, G. S.; SERPELLONI, G. B.; VIEIRA, A. M. S.; NISHI, L.; CARDOSO, K. C.; BERGAMASCO, R. Study of the effect of saline solution on the extraction of the Moringa oleifera seed's active component for water treatment. Water, Air and Soil Pollution, v. 211, n. 1-4, p. 409-415, 2010. https://doi.org/10.1007/s11270-009-0309-0

MALIK, Q. H. Performance of Alum and Assorted Coagulants in Turbidity Removal of Muddy Water. Applied Water Science, v. 8, n. 40, 2018. https://doi.org/10.1007/s13201-018$0662-5$

MATEUS, G. A. P.; SANTOS, T. R. T.; SANCHES, I. S.; SILVA, M. F.; ANDRADE, M. B.; PALUDO, M. P.; GOMES, R. G.; BERGAMASCO, R. Evaluation of a magnetic coagulant based on $\mathrm{Fe} 3 \mathrm{O} 4$ nanoparticles and Moringa oleifera extract on tartrazine removal: coagulation-adsorption and kinetics studies. Environmental Technology, v. 41, p. 1648-1663, 2020. https://doi.org/10.1080/09593330.2018.1543358

NISHI, L.; MADRONA, G. S.; VIEIRA, A. M. S.; BASSETI, F. J.; SILVA, G. F.; BERGAMASCO, R. Coagulação/Floculação com Sementes de Moringa oleifera Lam para Remoção de Cistos de Giardia spp. e Oocistos de Cryptosporidium spp. da água. In: INTERNATIONAL WORKSHOP: ADVANCES IN CLEANER PRODUCTION, 3. May 18-20 2011, São Paulo. Papers[...] São Paulo: UNIP, 2011.

NKURUNZIZA, T.; NDUWAYEZU, J. B.; BANADDA, E. N.; NHAPI, I. The effect of turbidity levels and Moringa oleifera concentration on the effectiveness of coagulation in water treatment. Water Science and Technology, v. 59, n. 8, p. 1551-1558, 2009. https://doi.org/10.2166/wst.2009.155

OLIVEIRA, J. C.; VIEIRA, I. C. G.; ALMEIDA, A. S.; SILVA JUNIOR, C. A. Floristic and Structural Status of Forests in Permanent Preservation Areas of Moju River Basin, Amazon Region. Brazilian Journal of Biology, v. 76, n. 4, 2016. https://doi.org/10.1590/1519-6984.04415

ORGANIZAÇÃO PAN-AMERICANA DA SAÚDE. Água e saúde. Brasília, 2001.

RAMAVANDI, B. Treatment of water turbidity and bacteria by using a coagulant extracted from Plantago ovata. Water Resources and Industry, v. 6, p. 3-50, 2014. https://doi.org/10.1016/j.wri.2014.07.001

RICHTER, C. A. Água: métodos e tecnologia de tratamento. São Paulo: Blucher, 2009.

RICHTER, C. A.; AZEVEDO NETTO, J. M. de. Tratamento de água: tecnologia atualizada. São Paulo: Edgard Blücher, 1991.

SALAZER GÁMEZ, L. L.; LUNA-DEL RISCO, M.; CANO, R. E. S. Comparative study between $M$. oleifera and aluminum sulfate for water treatment: case study Colombia. Environmental Monitoring and Assessment, v. 187, n. 10, 2015. https://doi.org/10.1007/s10661-015-4793-y 
SÁNCHEZ-MARTIN, J.; GHEBREMICHAEL, K.; BELTRÁN-HEREDIA, J. Comparison of single-step and two-step purified coagulants from Moringa oleifera seed for turbidity and DOC removal. Bioresource Technology, v. 101, n. 15, p. 6269-6261, 2010. https://doi.org/10.1016/j.biortech.2010.02.072

SIA, G. B.; VERNASQUI, L. G.; CONSOLIN-FILHO, N.; GONÇALVES, M. S.; SILVAMEDEIROS, F.V. Zinc adsorption from aqueous solution on biosorbent from urban pruning waste. Environmental Technology, v. 41, p. 1-10, 2020. https://doi.org/10.1080/09593330.2020.1803418

TIRADO, D. F.; HERRERA, A. P.; ACEVEDO CORREA, D. Evaluation of the Coagulant Capacity of Starch Obtained from Topocho Pelipita Plantain Clone (Musa abb) for Turbidity and Color Removal in Raw Waters. Revista Internacional de Contaminación Ambiental, v. 33, p. 125-134, 2017. http://dx.doi.org/10.20937/RICA.2017.33.esp01.11

VALVERDE, K. C.; COLDEBELLA, P. F.; SILVA, M. F.; NISHI, L.; BONGIOVANI, M. C.; BERGAMASCO, R. Moringa oleifera Lam. and Its Potential Association with Aluminium Sulphate in the Process of Coagulation/Flocculation and Sedimentation of Surface Water. International Journal of Chemical Engineering, v. 2018, 2018. https://doi.org/10.1155/2018/4342938

ZHOU, T.; XIA, F.; DENG, Y. Removal of Pb(II) from aqueous solutions using waste textiles/poly(acrylic acid) composite synthesized by radical polymerization technique. International Journal of Environmental Science, v. 67; p. 368-377, 2018. https://doi.org/10.1016/j.jes.2017.04.010 


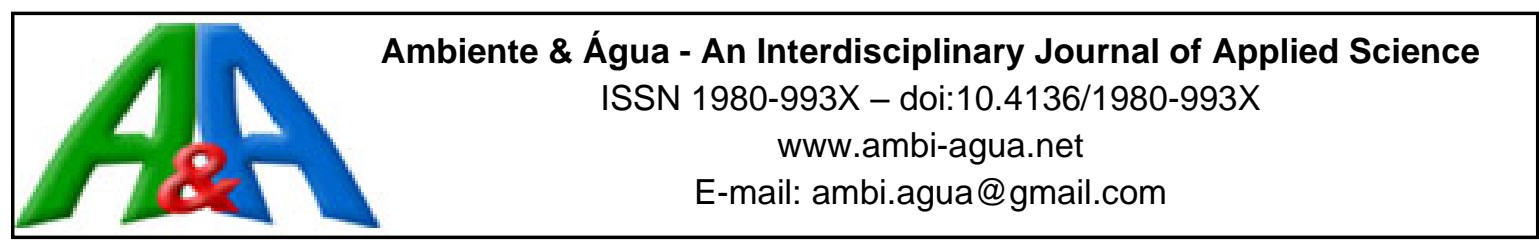

\title{
Study of the performance of disinfection with sodium hypochlorite on a full-scale sewage treatment plant
}

ARTICLES doi:10.4136/ambi-agua.2652

Received: 29 Sep. 2020; Accepted: 13 Oct. 2020

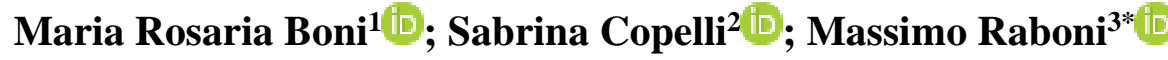 \\ ${ }^{1}$ Department of Civil, Constructional and Environmental Engineering (DICEA). University of Rome "La \\ Sapienza", Piazzale Aldo Moro, n 5, 00185, Roma, Italy. E-mail: mariarosaria.boni@ing.uniroma1.it \\ ${ }^{2}$ Department of Science and High Technology. University of Insubria, Via Ravasi, ${ }^{\circ} 2,21100$, Varese, Italy. \\ E-mail: sabrina.copelli@uninsubria.it \\ ${ }^{3} \mathrm{PhD}$ in Civil Engineering. University of Pavia, Corso Str. Nuova, ${ }^{\circ} 65,27100$, Pavia, Italy \\ *Corresponding author. E-mail: massimo.raboni@gmail.com
}

\begin{abstract}
A full-scale sewage treatment plant was investigated to assess the performance of the disinfection stage. Sodium hypochlorite was used as a disinfectant agent and the process efficiency was evaluated by E.coli removal. The research took place over a period of two years in order to evaluate the effect of retention time $(\mathrm{t})$ and residual chlorine $(\mathrm{Cr})$ under different seasonal conditions. The effectiveness of E.coli removal with sodium hypochlorite proved to be strictly dependent on the factor $C_{R} t$ (product of residual chlorine with the contact time). The regression line of the experimental points was, on the whole, well comparable with the model proposed by Collins, especially in the field of $\mathrm{C}_{\mathrm{R}} \mathrm{t}$ lower than $30 \mathrm{mg} \mathrm{L}^{-1} \mathrm{~min}$.
\end{abstract}

Keywords: disinfection, Escherichia coli, sewage treatment plants.

\section{Estudo do desempenho da desinfecção com hipoclorito de sódio em uma planta de tratamento de esgoto em escala real}

\section{RESUMO}

Uma estação de tratamento de esgoto em escala real foi investigada para avaliar o desempenho da etapa de desinfecção. Hipoclorito de sódio foi utilizado como desinfetante e a eficiência do processo foi avaliada pela remoção de E. coli. A pesquisa durou dois anos para avaliar o efeito do tempo de retenção $(t)$ e do cloro residual $\left(C_{R}\right)$ em diferentes condições sazonais. A eficácia da remoção de E. coli com hipoclorito de sódio provou ser estritamente dependente do fator $\mathrm{C}_{\mathrm{R}} \mathrm{t}$ (produto do cloro residual com o tempo de contato). A linha de regressão dos pontos experimentais é, em geral, bem comparável ao modelo proposto por Collins, especialmente no campo de $\mathrm{C}_{\mathrm{R}} \mathrm{t}$ inferior a $30 \mathrm{mg} \mathrm{L}^{-1} \mathrm{~min}$.

Palavras-chave: desinfecção, Escherichia coli, estações de tratamento de esgoto.

\section{INTRODUCTION}

The microbiological analysis of water and wastewaters commonly refer to micro-organism indicators. Fecal coliforms have been used for many years, but more recently E.coli was taken 
as a more specific indicator, thus becoming the reference parameter for much international and local legislation.

Sewage treatment plants play an important role in the removal of typical pollution parameters such as $\mathrm{BOD}_{5}$, COD, Total Nitrogen (TN) (Luciano et al., 2012; Viotti et al., 2014), total phosphorus (Ptot) and suspended solids (SS), but they are also very effective in removing microbiological pollution. They also remove some types of drugs (Chiavola et al., 2019). The scientific literature is full of information on total and fecal coliforms in sewage and on their removal efficiency. Fecal coliforms are detected in raw sewage in the range of $10^{6}-10^{8} 100 \mathrm{ml}^{-}$ 1, while E.coli concentration is in the range 5.5-7.0 $10^{6} 100 \mathrm{ml}^{-1}$ (Tchobanoglous et al., 2003; Raboni et al., 2016; Demir, 2016). Sewage treatment plants can remove these indicators by 90$98 \%$, and an effective additional removal of up to $99.999 \%$ can be achieved by a final disinfection process. Currently the most advanced treatment plants use strong disinfectant agents such as ozone, UV rays, peracetic acid, and others (Castro Ribas and Fortes Neto, 2008; de Oliveira Pereira et al., 2011; Amin et al., 2013; Verma et al., 2015; Barreto Camilo Junior et al.; 2019; de Almeida Soares Oliveira et al., 2019;) but the traditional sodium hypochlorite is still the most widely used all over the world due to its low cost and ease of use. We investigated a full-scale sewage treatment plant located in an area north of Milan, Italy. As shown in Figure 1, the plant performs biological denitrification and oxidation-nitrification followed by phosphorus precipitation. It is a very well-studied, widely applied process (USEPA 1997; 2010; Capodaglio et al., 2015; Copelli et al., 2015; Raboni et al., 2015; 2016; 2017; Torretta et al., 2013; 2014; Viotti et al., 2016). The plant is also equipped with a final disinfection unit (open contact chamber with baffles) to which $\mathrm{NaClO}$ (solution $15 \%$ as $\mathrm{Cl}_{2}$ ) is dosed.

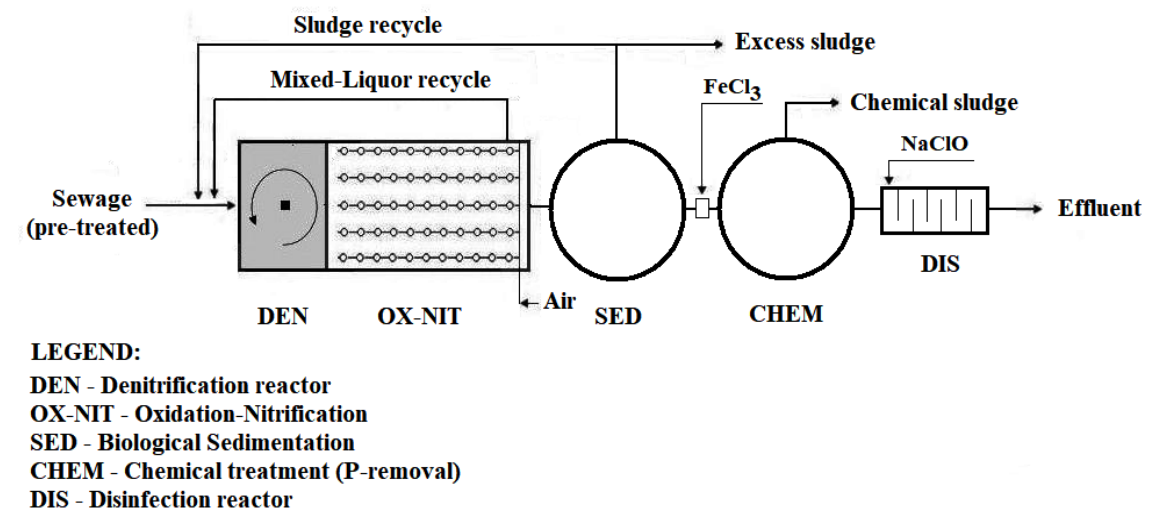

Figure 1. Simplified layout of the sewage treatment plant.

The correlation between the disinfection performance with the factors contact time $t$ and residual chlorine $\mathrm{CR}$ is cited several times in the scientific literature.. Among these, the research recently carried out on 6 full-scale plants deserves particular mention (Raboni et al., 2016). The present research has been developed in a similar way, but over a much longer period of time ( 2 years) so as to also include the possible effects of the different seasons and related climatic conditions.

\section{MATERIALS AND METHODS}

\subsection{The wastewater treatment plant}

Table 1 shows the main features of the plant. Of course, the retention times reported represent the average values, as they vary significatively over time because of the fluctuations of the wastewater flow rate (daily and seasonal fluctuations). 
Table 1. Characteristics of the sewage treatment plants.

\begin{tabular}{ccccc}
\hline \multirow{2}{*}{$\begin{array}{c}\text { Flow rate } \\
\left(\mathbf{m}^{\mathbf{3}} \mathbf{d}^{\mathbf{1}}\right) *\end{array}$} & $\begin{array}{c}\text { Capacity } \\
(\text { eq. inh.) }\end{array}$ & \multicolumn{3}{c}{ Av. Retention time*** } \\
\cline { 3 - 5 } & 80,000 & $\begin{array}{c}\text { Biological } \\
\text { Denitrification (h) }\end{array}$ & $\begin{array}{c}\text { Biological } \\
\text { Oxidation-Nitrification (h) }\end{array}$ & Disinfection (min) \\
\hline 33,000 & 4.5 & 14.1 & 25 \\
\hline
\end{tabular}

* referred to average flow rate in dry weather

** by assuming $60 \mathrm{~g} \mathrm{BOD}_{5} \mathrm{~d}^{-1}$ inh $^{-1}$

$* * *$ referred to average flow rate in dry weather

The performance of the plant is shown in Figure 2, by the parameters $\mathrm{BOD}_{5}, \mathrm{COD}$, Suspended Solids, TKN, $\mathrm{NO}_{3}-\mathrm{N}$ and $\mathrm{P}$. Statistical data are referred to mean values and relative Standard Deviation (SD) of both raw sewage and treated effluent. The plant runs in full compliance with the discharge limits issued by Italian legislation: $\mathrm{BOD}_{5}=25 \mathrm{mg} \mathrm{L}^{-1}, \mathrm{SS}=\mathrm{mg}$ $\mathrm{L}^{-1}, \mathrm{TN}=10 \mathrm{mg} \mathrm{L}^{-1}, \mathrm{P}_{\text {tot }}=1 \mathrm{mg} \mathrm{L}^{-1}$. As to E.coli the average values in raw sewage and in the final effluent after disinfection are $5.910^{6} 100 \mathrm{~mL}^{-1}$ and 2,600 $100 \mathrm{~mL}^{-1}\left(\mathrm{SD}=480100 \mathrm{~mL}^{-}\right.$ ${ }^{1}$ ) respectively. Always with reference to E.coli the discharge limits issued by Italian legislation is E.coli $=5,000 \mathrm{CFU} 100 \mathrm{~mL}^{-1}$.

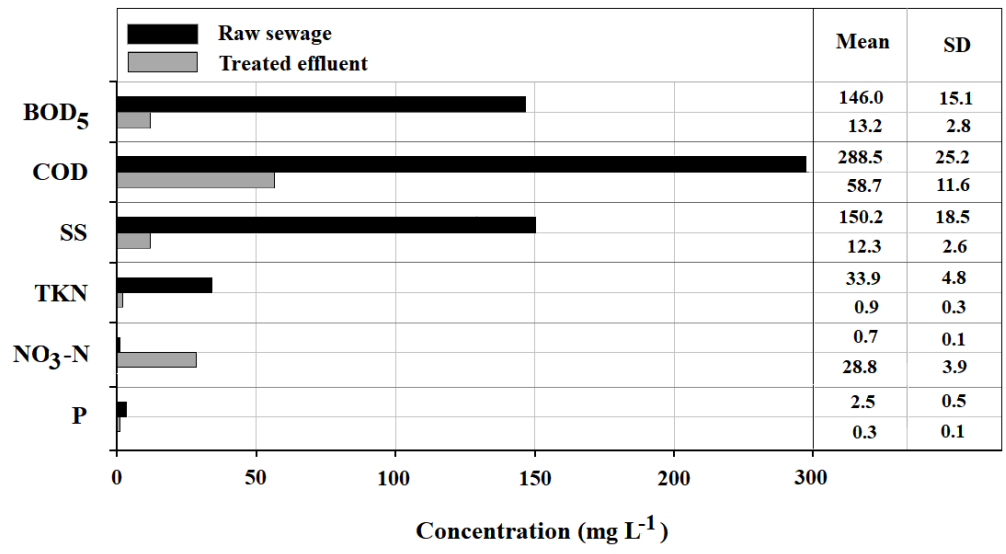

Figure 2. Statistical data of the plant performance referred to $\mathrm{BOD}_{5}, \mathrm{COD}$, Suspended Solids, TKN, $\mathrm{NO}_{3}-\mathrm{N}$ and $\mathrm{P}$.

\subsection{Sampling and analysis}

The investigation lasted 24 months during which 48 sampling campaigns were carried out. The sampling points were at inlet and outlet of disinfection chamber and E.coli in samples was enumerated by the membrane filtration technique and the results were expressed in Colony Forming Units (CFUs) per $100 \mathrm{~mL}^{-1}$. At the same time, various operating data of the plant were collected, among which wastewater flow rate, temperature, $\mathrm{pH}$ and residual chlorine at the end of disinfection. The retention time in the disinfection reactor was calculated in correspondence with the corresponding flow rate.

Sampling and analyses were carried out in accordance with the official analytical methods of Italian legislation, issued by the IRSA-Institute for Water Research of the Italian National Research Council and APAT-Agency for the protection of the Environment and Technical Services (IRSA and APAT, 2003)

The data collected with this analytical campaign were used to verify the correlation of the E.coli removal efficiency with $\mathrm{C}_{\mathrm{R}} \mathrm{t}$ (product of residual chlorine at the end of the disinfection reactor with the contact time). Thus, a total of 96 instantaneous samples were collected for the E.coli count.

The residual chlorine was detected with a portable HI Series HI711 analyzer using a fixed 
wavelength LED and silicon photodetector, in the range $0-3.00 \mathrm{mg} \mathrm{L}^{-1}$, resolution= $0.01 \mathrm{mg} \mathrm{L}^{-1}$. These measures were compared with the residual chlorine amperometric analyzers mounted in line.

In order to make the graphic representation easier, the disinfection performance was evaluated by the efficiency ratio Eo/E, where Eo represents the E.coli concentration at the inlet of disinfection and $\mathrm{E}$ at the outlet.

\section{RESULTS AND DISCUSSION}

In Italy, the disinfectant dosage is set to obtain a concentration of E.coli in the final effluent of less than $5000 \mathrm{CFUs} 100 \mathrm{~mL}^{-1}$ (recommended limit according to Italian legislation). Thus, the dosage normally varies in the range of 3-6 $\mathrm{mg} \mathrm{L}^{-1}\left(\right.$ as $\mathrm{Cl}_{2}$ ), depending on the plant. For instance, higher dosages are necessary in plants with still rather high values of TKN and SS in the treated effluent. Conversely, in plants with a high efficiency of nitrification and of suspended solids removal, smaller doses are required. In this specific plant, due to the strong nitrification and to the polishing effect of tertiary treatment, the $\mathrm{NaClO}$ dosage was limited in the range $1.5-3.5 \mathrm{mg} \mathrm{L}^{-1}$ (as $\mathrm{Cl}_{2}$ ).

Figure 3 shows the experimental correlation between the efficiency ratio of disinfection $\mathrm{Eo} / \mathrm{E}$ with the product of chlorine residual $\mathrm{C}_{\mathrm{R}}$ with the contact time $\mathrm{t}$. The regression line of the experimental points demonstrates a logarithmic-like growth, i.e., with a progressively higher gradient at increasing values of the product $\mathrm{C}_{\mathrm{R}} \mathrm{t}$. In reality, as shown in the Figure 3 , the best interpolation of the experimental points is given by a third degree polynomial equation with a correlation factor $\mathrm{R}^{2}=0.8923$. This value of $\mathrm{R}^{2}$ and the $95 \%$ confidence interval represented in the Figure 3 allow a good level of reliability of the regression line (especially at low-medium values of $\mathrm{C}_{\mathrm{R}} \mathrm{t}$ ). But, at the same time, it should be noted that this experimentation did not highlight the specific role of temperature, which could be more than appreciable considering the wide range assumed in the long experimentation period $\left(\mathrm{T}=12-22^{\circ} \mathrm{C}\right)$. In fact, the scientific research has not yet adequately investigated the influence of temperature which, when properly considered, could lead to an improvement in the level of reliability of the experimental correlation represented in Figure 3.

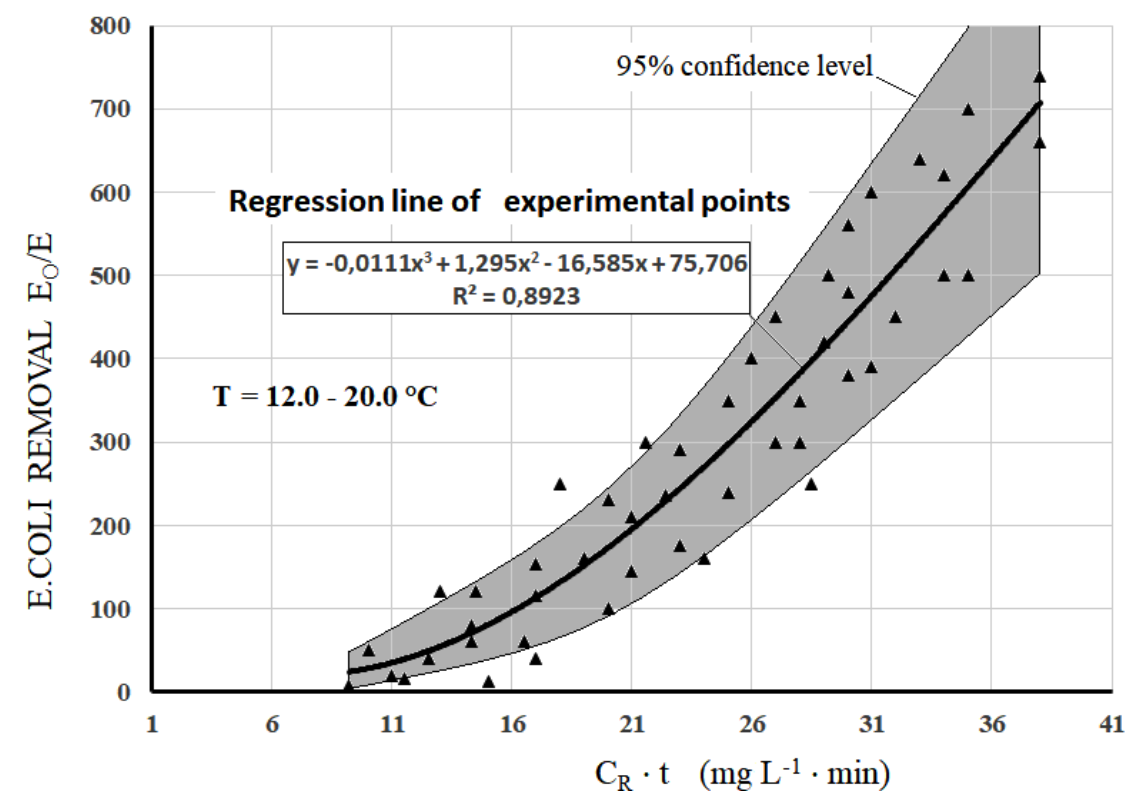

Figure 3. E.coli removal by disinfection with sodium hypochlorite, as a function of $\mathrm{C}_{\mathrm{R}} \mathrm{t}$ (product of chlorine residual with contact time). 
The choice of the efficiency ratio Eo/E allows a good comparison of the experimental results with two of the most commonly used models to describe the performance of the chlorine disinfection of secondary effluents (Tchobanoglous et al., 2003; White, 1999; 2010; Collins, 1970; 1972):

- Collins model $\mathrm{Eo} / \mathrm{E}=\left(1+0.23 \mathrm{C}_{\mathrm{R}} \mathrm{t}\right)^{3}$

- The White model Eo/E $=\left[\left(\mathrm{C}_{\mathrm{R}} \mathrm{t}\right) / \mathrm{b}\right]^{\mathrm{n}}$

where the typical value of the constants, for fecal coliforms are $b=3.0$ and $n=2.8$.

Figure 4 shows this comparison, which proves that the experimental curve fits well the Collins model at $\mathrm{C}_{\mathrm{R}}$ t values of lower than about $30 \mathrm{mg} \mathrm{L}^{-1} \mathrm{~min}$. Figure 5 shows in detail the deviation of the experimental curve from the two models. The deviation is defined as the percentage difference between the Eo/E values of the models compared to those of the experimental curve, at different values of the product $\mathrm{C}_{\mathrm{R}} \mathrm{t}$. It can be observed that within the range $\mathrm{C}_{\mathrm{R}} \mathrm{t}=20-30 \mathrm{mg} \mathrm{L}^{-1} \mathrm{~min}$ the deviation of the experimental curve from the Collins model is lower than about $10 \%$. However, at values greater than $30 \mathrm{mg} \mathrm{L}^{-1} \mathrm{~min}$, this percentage tends to approximate $20 \%$ deviation. On the contrary, the deviation of the experimental curve from the White model is always higher than $10 \%$, thus making them hardly comparable.

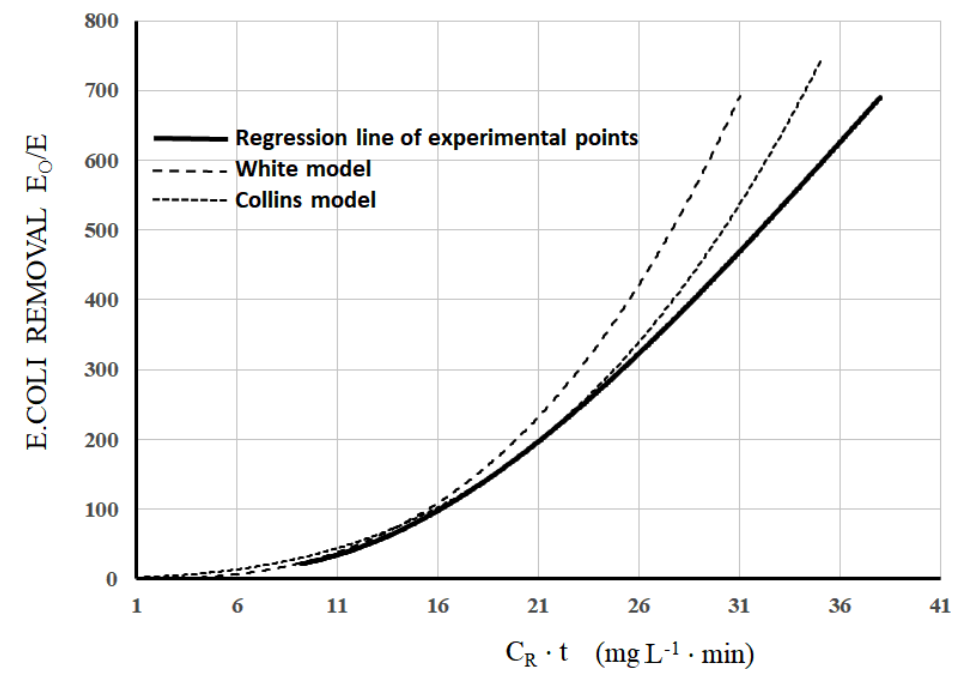

Figure 4. Comparison of the experimental curve with the Collins and White models.

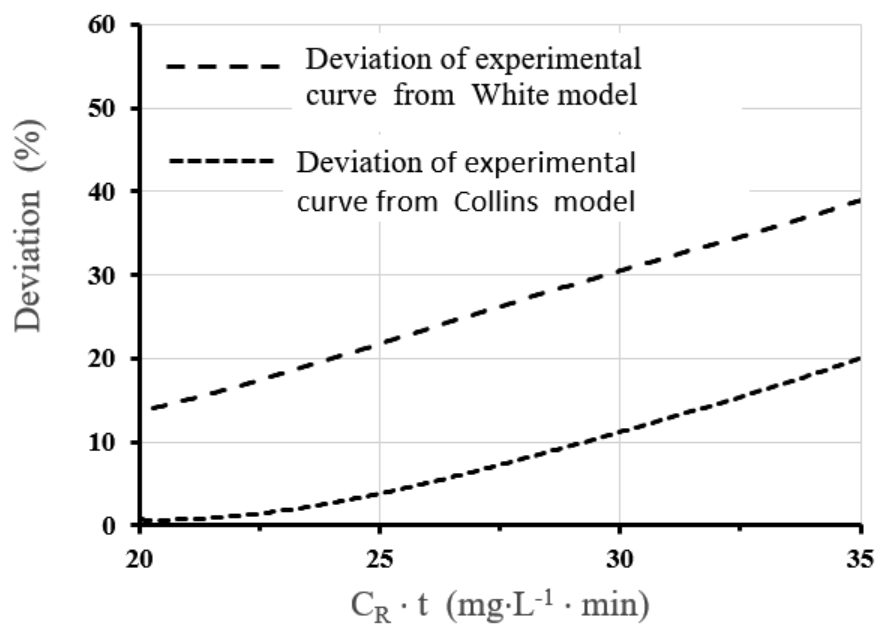

Figure 5. Deviation (\%) of the experimental curve from the White and Collins Models. 
With regard to what is illustrated in the last two figures, attention must be focused on an important aspect: the absence of the temperature factor in the two models examined. In reality, the influence of this factor on the efficiency of disinfection has not yet been adequately studied, although it is recognized that it affects all types of chemical and biochemical kinetics. Thus, it is likely that in sewage treatment plants with significant variations in temperatures the simulation models should be implemented. Furthermore, the deviation in efficiency among the curves could be partially explained by the above considerations.

\section{CONCLUSIONS}

The disinfection treatment with sodium hypochlorite in a full scale sewage treatment plant was investigated for two years in order to highlight the role of the two factors residual chlorine $\mathrm{C}_{\mathrm{R}}$ and contact time $\mathrm{t}$. In this research, the disinfection efficiency was represented by the efficiency ratio $\mathrm{E} / \mathrm{E}$ (ratio of E.coli at disinfection inlet and outlet, respectively)

The experimental results demonstrate the key role of the factor $\mathrm{C}_{\mathrm{R}} \mathrm{t}$ (product of the residual chlorine with the contact time). The regression line of the experimental points shows a progressively higher gradient of Eo/E at increasing values of the product $\mathrm{C}_{\mathrm{R}}$. The line could be represented by a polynomial equation with a correlation factor $\mathrm{R}^{2}=0.8923$. The results of the research show that the experimental curve tends to fit well with the Collins model $\mathrm{Eo} / \mathrm{E}=(1+$ $0.23 \mathrm{C}_{\mathrm{R}} \mathrm{t}^{3}$ at $\mathrm{C}_{\mathrm{R}} \mathrm{t}$ values below about $30 \mathrm{mg} \mathrm{L}^{-1} \mathrm{~min}$. In order to achieve further advances in this field, it is recommended that further in-depth studies on the concomitant role of temperature be conducted. The information gleaned would lead to the development of more complete and reliable models for simulating the disinfection process.

\section{REFERENCES}

AMIN, M.M.; HASSAN, H.; ASHEM, I H.; BOVINI, A.M.; YUNG TSE HUNG, Y. A review on wastewater disinfection. International Journal of Environmental Health Engineering, v. 2, n. 1, p. 1-9, 2013. https://dx.doi.org/10.4103/2277-9183.113209

BARRETO CAMILO JÚNIOR, O.; SANDRI, D.; RODRIGUES DE ALENCAR, E.; FERRAZ HEBLING, L. Ozonation improves physical attributes in domestic sewage effluent. Revista Ambiente \& Água, v. 14, n. 2, 2019. https://dx.doi.org/10.4136/ambi-agua.2328

CASTRO RIBAS, T.; FORTES NETO, P. Disposição no solo de efluentes de esgoto tratado visando à redução de coliformes termotolerantes. Revista Ambiente \& Água, v. 3, n. 3, p. 81-94, 2008. https://dx.doi.org/10.4136/ambi-agua.63

CAPODAGliO, A. G., HLAVÍNEK, P., RABONI, M. Physico-chemical technologies for nitrogen removal from wastewaters: a review. Revista Ambiente \& Água, p. 481-498, 2015. https://dx.doi.org/10.4136/ambi-agua.1618

CHIAVOLA, A.; TEDESCO, P.; BONI, M. R. Fate of selected drugs in the wastewater treatment plants (WWTPs) for domestic sewage. Environmental Science and Pollution Research, p. 1113-1123, 2019. https://dx.doi.org/10.1007/s11356-017-9313-x

COLLINS, H. F. Effects of initial mixing and Residence Time Distribution on the efficiency of the wastewater chlorination process. In: THE CALIFORNIA STATE DEPARTMENT OF HEALTH ANNUAL SYMPOSIUM, 1970. Papers[...] Berkeley; Los Angeles, 1970.

Rev. Ambient. Água vol. 15 n. 6, e2652 - Taubaté 2020 
COLLINS, H. F.; SELLECK, R. E. Process kinetics of wastewater Chlorination. SERL Report 72-5 Sanitary Engineering Research Laboratory. Berkeley: University of California, 1972.

COPELLI, S.; RABONI, M.; URBINI, G. Water Pollution: Biological Oxidation and Natural Control Techniques. Reference Module in Chemistry, Molecular Sciences and Chemical Engineering, p. 1-28, 2015. https://dx.doi.org/10.1016/B978-0-12-4095472.11419-2

DE ALMEIDA SOARES OLIVEIRA, A.; GASPAR BASTOS, R.; FONSECA SOUZA, C. Adaptation of domestic effluent for agricultural reuse by biological, physical treatment and disinfection by ultraviolet radiation. Revista Ambiente \& Água, v. 14, n. 2, 2019. https://dx.doi.org/10.4136/ambi-agua.2292

DEMIR, F. Development and validation of a simulation model to determine the reaction rate constant of chlorine disinfection process at a wastewater treatment plant. Desalination $\begin{array}{lllllll}\text { and Water } & \text { Treatment, } & \text { v. } & 57, & \text { n. } & 19,\end{array}$ https://doi.org/10.1080/19443994.2015.1023850

DE OLIVEIRA PEREIRA, L. C.; ROSSO, T.; CABONELLI CAMPOS, J.; GIORDANO, G. Fenton's reagent application in the domestic sewers disinfection. Revista Ambiente \& Água, v. 6, n. 1, p. 65-76, 2011. https://dx.doi.org/10.4136/ambi-agua.174

IRSA (U.S.); APAT. Analytical methods for water-Report 29/2003. Rome, 2003.

LUCIANO, A.; VIOTTI, P.; MANCINI, G.; TORRETTA, V. An integrated wastewater treatment system using a BAS reactor with biomass attached to tubular supports. Journal $\begin{array}{lllll}\text { of Environmental } & \text { Management, } & \text { p. } & \text { 51-60, }\end{array}$ https://dx.doi.org/10.1016/j.jenvman.2012.08.034

RABONI, M.; GAVASCI, R.; VIOTTI, P. Influence of denitrification reactor retention time distribution (RTD) on dissolved oxygen control and nitrogen removal efficiency. Water Science \& Technology, v. 72, p. 45-51, 2015. https://dx.doi.org/10.2166/wst.2015.188

RABONI, M.; GAVASCI, R.; TORRETTA, V. Assessment of the Fate of Escherichia coli in Different Stages of Wastewater Treatment Plants. Water, Air, \& Soil Pollution, p. $227-$ 455, 2016. https://dx.doi.org/10.1007/s11270-016-3157-8

RABONI, M.; TORRETTA, V. Validation of a new model for the sizing of denitrification reactors, by testing full-scale plants. Environmental Technology, v. 38, p. 1376-1382, 2017. https://doi.org/10.1080/09593330.2016.1228700

TCHOBANOGLOUS, G.; BURTON, F. L.; STENSEL, H. D. Wastewater Engineering: Treatment and Reuse. New York: McGraw-Hill, 2003.

TORRETTA, V.; RAGAZZI, M.; TRULLI, E.; DE FEO, G.; URBINI, G.; RABONI, M.; RADA, E.C. Assessment of biological kinetics in a conventional municipal WWTP by means of the oxygen uptake rate method. Sustainability, v. 6, p. 1833-1847, 2014. https://dx.doi.org/10.3390/su6041833

TORRETTA, V.; URBINI, G.; RABONI, M.; COPELlI, S.; VIOTTI, P.; LUCIANO, A.; MANCINI, G. Effect of Powdered Activated Carbon to Reduce Fouling in Membrane Bioreactors: A Sustainable Solution. Case Study. Sustainability, v. 5, n. 4, p. 1501-1509, 2013. https://doi.org/10.3390/su5041501 
USEPA. Waste Water Treatment Manuals Primary, Secondary And Tertiary Treatment. Washington, 1997.

USEPA. Nutrient Control Design Manual. EPA/600/R-10/100. Washington, 2010.

VERMA, K.; GUPTA, K. D.; GUPTA, A. B. A review on sewage disinfection and need of improvement. Desalination and Water Treatment, v. 56, n. 11, p. 2867-28, 2015. https://doi.org/10.1080/19443994.2014.967307

VIOTTI, P.; LUCIANO, A.; MANCINI, G.; TORRETTA, V. A wastewater treatment using a biofilm airlift suspension reactor with biomass attached to supports: A numerical model. International Journal of Environmental Science and Technology, p. 571-588, 2014. https://dx.doi.org/10.1007/s13762-013-0256-6

VIOTTI, P.; COLLIVIGNARELLI, M. C.; MARTORELLI, E.; RABONI, M. Oxygen control and improved denitrification efficiency by dosing ferrous ions in the anoxic reactor.

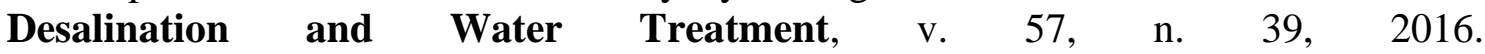
https://dx.doi.org/10.1080/19443994.2015.1089200

WHITE, G. C. Handbook of Chlorination and Alternatives Disinfectants. 4th ed. New Yoirk: Wiley \& Sons, 1999.

WHITE, G. C. White's Handbook of Chlorination and Alternative Disinfectants. 5th ed. New York: John Wiley \& Sons, 2010. 


Ambiente \& Água - An Interdisciplinary Journal of Applied Science
ISSN 1980-993X - doi:10.4136/1980-993X
www.ambi-agua.net
E-mail: ambi.agua@gmail.com

\title{
Medium-term projection for the National Hydro-Electrical System using wavelets
}

\author{
ARTICLES doi:10.4136/ambi-agua.2583
}

Received: 21 May 2020; Accepted: 05 Oct. 2020

\section{Francisco Wellington Martins da Silva ${ }^{1^{*} \text {; }}$; Cleiton da Silva Silveira ${ }^{2}$; Antônio Duarte Marcos Junior ${ }^{3}$; João Dehon de Araujo Pontes Filho ${ }^{2}$}

\footnotetext{
${ }^{1}$ Instituto de Engenharia e Desenvolvimento Sustentável. Universidade da Integração Internacional da Lusofonia Afro-Brasileira (UNILAB), Rua José Franco de Oliveira, s/n, CEP: 62790-970, Redenção, CE, Brazil.

${ }^{2}$ Centro de Tecnologia. Departamento de Engenharia Hidráulica. Universidade Federal do Ceará (UFC), Avenida. Mister Hull, Campus do Pici, Bloco 713, Cep: 60440-970, Fortaleza, CE, Brazil. E-mail: cleitonsilveira@ufc.br, dehonambiental@gmail.com

${ }^{3}$ Centro de Ciências e Tecnologias. Universidade Estadual do Ceará (UECE), Avenida Paranjana, $\mathrm{n}^{\circ}$ 1700, CEP: 84030-900, Fortaleza, CE, Brazil. E-mail: duarte.jr105@gmail.com

*Corresponding author. E-mail: martinswellington29@yahoo.com.br
}

\begin{abstract}
The Brazilian energetic matrix is predominantly based on hydroelectric plants and its planning is very sensitive to climate variability in different time scales. Natural Affluent Energy (NAE) is an established planning tool to project different scenarios of possible energy production, especially in an integrated system. This work aims to fill a gap between short-term (seasonal/ interannual) and long-term (climate change) planning scales by realizing NAE medium-term projections for the Brazilian National Interconnected System basins. The historical NAE series provided by the National System Operator was used for the years 1931 to 2014. The series was divided into two periods: from 1931 to 2003 for verification, and from 2004 to 2014 for calibration. The Wavelets Auto-Regressive (WAR) model was applied from low- and medium-frequency bands. The band signal was analyzed and the NAE was projected for the years 2014 to 2024 . A relationship of the NAE variability with the Pacific Decadal Oscillation (PDO) climate index and the Atlantic Multidecadal Oscillation (AMO) was verified.
\end{abstract}

Keywords: medium-term projection, natural affluent energy, wavelets.

\section{Projeção a médio prazo para o Sistema Hidroelétrico Nacional utilizando wavelets}

\section{RESUMO}

A matriz energética brasileira é predominantemente baseada em hidrelétricas e seu planejamento é muito sensível à variabilidade climática em diferentes escalas de tempo. A Energia Afluente Natural (ENA) é uma ferramenta de planejamento estabelecida para projetar diferentes cenários de possível produção de energia, especialmente em um sistema integrado. Este trabalho visa preencher uma lacuna entre as escalas de planejamento de curto prazo (sazonal/ interanual) e longo prazo (mudanças climáticas), realizando projeções de médio prazo da ENA para as bacias do Sistema Interligado Nacional Brasileiro. As séries históricas de ENA fornecidas pelo Operador Nacional do Sistema foram utilizadas para os anos de 1931 a 2014. 
Francisco Wellington Martins da Silva et al.

As séries foram divididas em dois períodos: de 1931 a 2003 para verificação e de 2004 a 2014 para calibração. O modelo Wavelets Auto-Regressivo (WAR) foi aplicado a partir de bandas de baixa e média frequência. O sinal das bandas foi analisado e a ENA foi projetada para os anos de 2014 a 2024. Foi verificada a relação da variabilidade da ENA com o índice climático da Oscilação Decadal do Pacífico (ODP) e a Oscilação Multidecadal do Atlântico (OMA).

Palavras-chave: energia natural afluente, projeção de médio prazo, wavelets.

\section{INTRODUCTION}

The consumption of goods and services associated with the advancement of technology, and the increase of the technologically active population, has increasingly demanded the use of more energy (ANEEL, 2017). Currently, Brazil has an energetic matrix that is predominantly renewable in terms of electricity production and, although it has tremendous environmental benefits, this category is known for its volatility due to climatic influence. This is a vulnerability of the energetic system, especially when it is too concentrated in one form of electricity production, such as in Brazil, where over $66 \%$ of total energy is generated by hydroelectric plants (EPE, 2011). The electrical generation by hydroelectric plants is highly dependent on climatic phenomena and, above all, good planning. Climate variability occurs at multiple time scales and affects decision making on water use.

Climate external forces such as El Niño, La Niña and Pacific Decadal Oscillation (PDO) contribute to natural inflows variability in the Brazilian electric sector, and consequently the power generated in hydroelectric plants. Knowing the behavior of these phenomena can greatly aid efficient and mitigating energy planning.

Many kinds of research had studied climate forces and their influence on hydrological variables. Studies such as Carvalho et al. (2004); Kodama (1993); Lazaro (2011) relate the Intertropical Convergence Zone (ITCZ) and the South Atlantic Convergence Zone (SACZ) with changes in rainfall in the SIN basins and the direct modification of the flow regime, impacting the Natural Affluent Energy (NAE), which is a direct product of hydroelectric productivity and streamflows.

Silva and Galvíncio (2011); Dantas (2012); Nascimento Júnior and Sant'Anna Neto (2016) showed that there is a relationship between interannual phenomena such as El Niño and the Atlantic dipole, modulated by low-frequency climatic phenomena, such as the Pacific Decadal Oscillation (PDO) (Mantua et al., 1997) and the Atlantic Multidecadal Oscillation (AMO) (Silva, 2013). Andreoli and Kayano (2005) identified a direct relationship of the El Niño episode in the positive phase of PDO and a higher occurrence of La Niña in the negative phase of PDO. The relationship between AMO and PDO influenced the total annual precipitation of the Western Amazon (Silva, 2012). According to Dantas (2012) rainfall and river flows in the Amazon and the Northeast present inter-annual variability and interdecadal time scale, which are more important than increasing or decreasing trends.

The statistical characteristics of a hydrological variable of a set of years or decades depend on both natural climate variability and anthropogenic forces. Decade-long climatic projections should try to bridge the gap between seasonal/interannual forecasts with deadlines of two years or less and project climate change a few decades ahead (Cane, 2010). There is no widely accepted theory for this type of projection; however, the decadal behaviour of Atlantic and Pacific Sea Surface Temperature (SST), AMO and PDO, can be introduced in projections of rainfall and streamflow to allow the consideration of low-frequency decadal variability. Kwon et al. (2007), considering the variability of temperature time series in England and rainfall in Florida, used a statistical model based on wavelet transform and observed that modelling was able to capture the memory of the low-frequency hydroclimatic series.

Rev. Ambient. Água vol. 15 n. 6, e2583 - Taubaté 2020 
Thus, this work presents a medium-term projection for the main basins of the National Interconnected System (NIS) from the temporal series of NAE, using wavelets to consider lowfrequency decadal variability.

\section{MATERIALS AND METHOD}

This work is divided into two main parts, according to Figure 1: (i) trend and variability analysis; followed by (ii) projections made for the entire electrical sector using wavelets. For this approach, trend/variability of the standardized annual series was analyzed by the following classical methods: 10-year moving average and Mann-Kendall-Sen (Burn and Elnur, 2002); and by wavelet transformation (Torrence and Compo, 1998), according to Equation 3. The wavelet-based model consists of the decomposition of time series into bands for all SIN basins for later use in the multivariate autoregressive model.

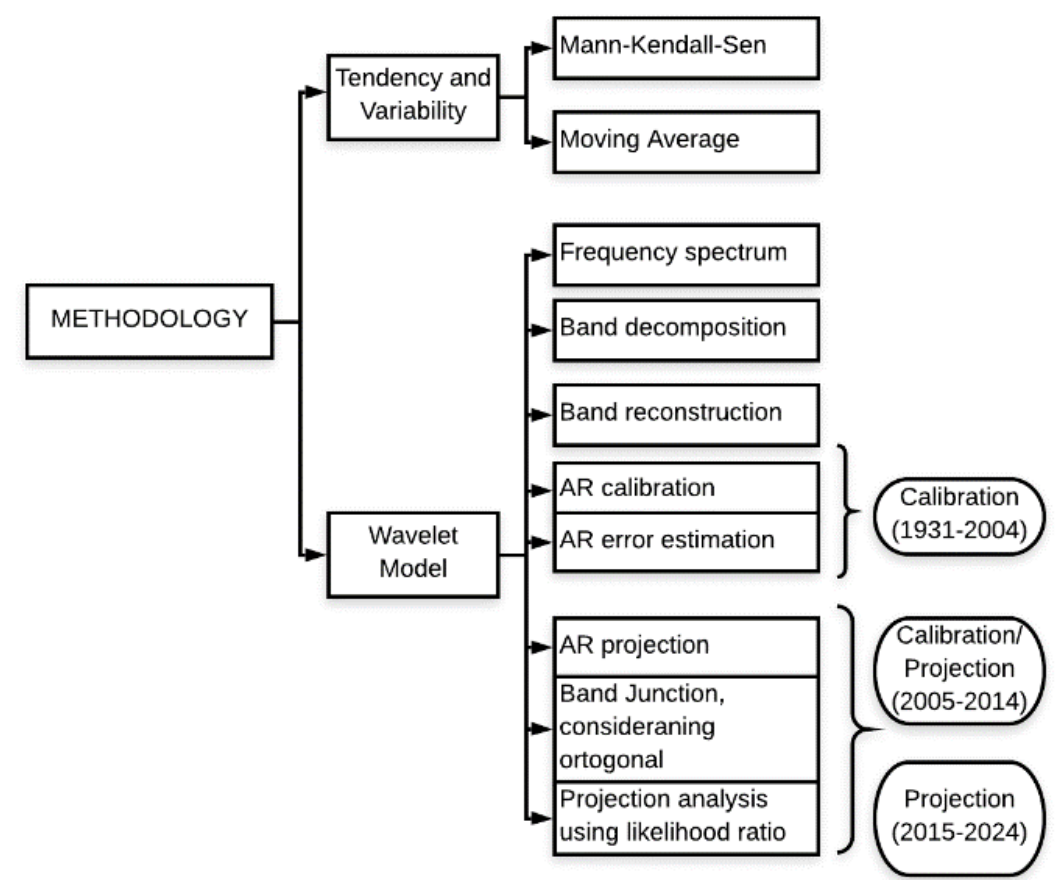

Figure 1. Methodology flowchart.

Data from NAE was made available by the National Electric System Operator (ONS) for the years 1931 to 2014. The series was divided into two periods; from 1931 to 2004 for calibration and from 2005 to 2014 for verification.

\subsection{National Interconnected System (SIN)}

The Brazilian electricity generation and transmission system is a large hydrothermal system with size and characteristics that allow it to be considered unique worldwide and have a strong predominance of hydroelectric power plants with multiple owners. Only $1.7 \%$ of the energy required by the country is outside the SIN, in small and isolated systems located mainly in the Amazon region (ONS, 2012).

The hydroelectric plants of the SIN are frequently built-in cascade systems (in the bed of the same river). Upstream plant operations interfere directly with downstream plant operations, so planning must be done in an integrated manner, increasing their complexity. The planning of the operation is done taking into account the operational interdependencies among the plants, as well as the interconnection among the subsystems. The SIN is divided into four subsystems: Southeastern/Midwestern Region, Southern Region, Northern Region and Northeastern Region. These Subsystems are interconnected by an extensive transmission network that 
enables the transfer of energy surpluses and allows the optimization of storage in the reservoirs of hydroelectric power plants and the integration of generation and transmission resources in the service to the total load of the system. (Ramos, 2011). Figure 2 shows the single-line diagram of the Grande and Paranaíba Basins as an example of a cascade model.

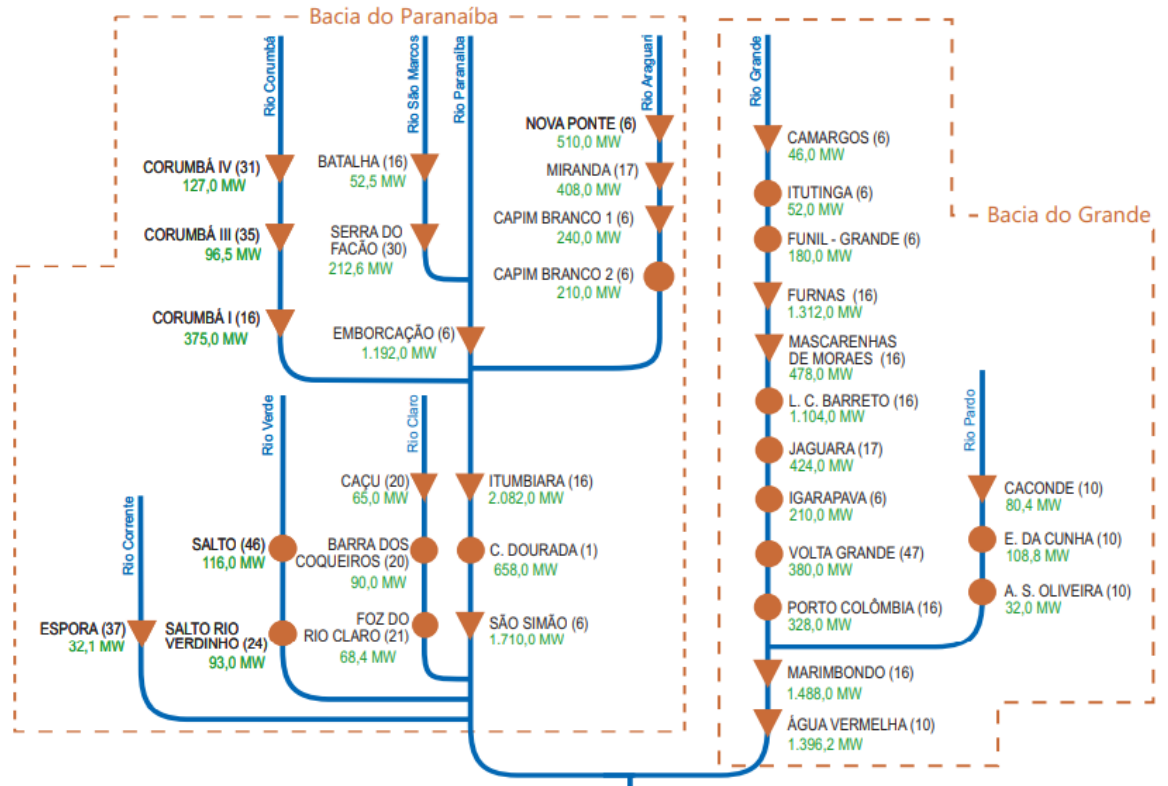

Figure 2. Hydroelectric use of the SIN in the Grande and Paranaíba

Basins.

Legend: The symbols $\rangle$, $\phi$ and $\rangle$ represent, respectively, a power plant with a reservoir; a power plant that has no water reservoir or has smaller or irrelevant dimensions; and a power plant under construction.

Source: ONS (2012).

\subsection{Natural Affluent Energy (NAE) Calculation}

An important variable in the hydroelectric planning framework is NAE, as it considers the interconnections between the different plants and watersheds from the monthly incremental flows of each hydroelectric station. It is obtained by multiplying the natural flow rate of each hydroelectric plant by its average productivity. Usually, the unit measure is $\mathrm{MW}_{\text {mean, which }}$ refers to the relationship between generated power and the facility operating time. It is calculated using the following Equations 1 and 2:

$$
\begin{aligned}
& \operatorname{NAE}_{\text {watersheds }}(t)=\sum_{i=1}^{n}\left[Q_{n a t}(i, t) \cdot p(i)\right] \\
& \operatorname{NAE}_{\text {subsystems }}(t)=\sum_{i=1}^{m}\left[Q_{n a t}(j, t) \cdot p(j)\right]
\end{aligned}
$$

Where:

$\mathrm{t}$ is the time interval considered for the NAE calculation;

$\mathrm{i}$ is the utilization of the system of the considered basin;

$\mathrm{n}$ is the number of stations in the system basin in question;

$Q_{\text {nat }}$ is the natural flow rate of the system in the time interval considered;

$\mathrm{p}$ is the average productivity of the turbine-generating set of the hydroelectric plant, referring to the fall obtained by the difference between the level of the amount, corresponding to storage of $65 \%$ of the useful volume, and the average level of the leakage channel; 
$\mathrm{j}$ is the utilization belonging to the utilization system of the subsystem considered; and $\mathrm{m}$ is the number of stations in the system.

Figure 3 (a) shows the basins whose NAE was estimated: Bacia Grande, Paranaíba, Paranapanema, Paraguai, Parnaíba, São Francisco, Tocantins, Doce, Uruguay, Jacuí, Amazonas, Paraná, Tietê, Iguaçu, Atlântico Suldeste, Atlântico Sul, Paraíba do Sul and Atlântico Leste. While Figure 3 (b) shows the subsystems.
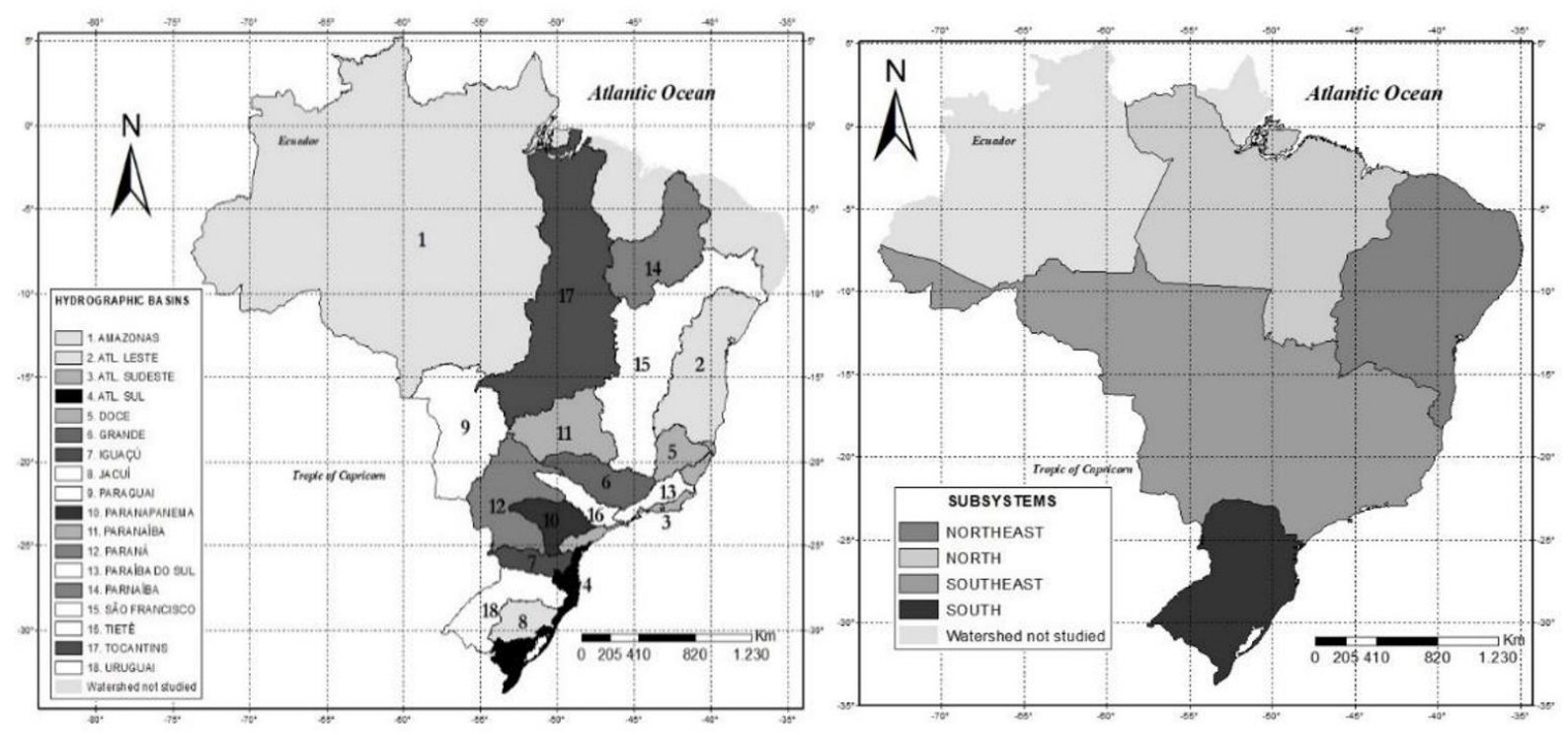

Figure 3. a) Hydrographic basins; b) Hydrographic subsystems.

\subsection{Mann-Kendall Test}

For the observed data $\mathrm{x}_{1}, \mathrm{x}_{2}, \ldots, \mathrm{x}_{\mathrm{k}}, \mathrm{x}_{\mathrm{j}}, \ldots, \mathrm{x}_{\mathrm{n}}$ of the NAE time series in the period from 1931 to 2014, the Mann-Kendall test was applied for a trend because the series is independent. To observe whether the variations of the series are independent and identically distributed, the test of the following hypotheses is considered:

i) $\mathrm{H}_{0}$ : There is no tendency if the observations of the time series are independent and identically distributed;

ii) $\mathrm{H}_{1}$ : There is a trend if the observations of the series have a monotonic tendency in time, that is, one of the variables increases or decreases its tendency.

Thus, the Mann-Kendall statistical test is given by Equation 3:

$S=\sum_{k=1}^{n-1} \sum_{j=k+1}^{n} \operatorname{Signal}\left(x_{j}-x_{k}\right)$

Where:

$x j$ and $x k$ are sequential values of NAE;

$\mathrm{n}$ is the size of the NAE time series;

The signal is the signal function.

$\operatorname{Signal}(x)=\left\{\begin{array}{cl}+1 & \text { if } x>0 \\ 0 & \text { if } x=0 \\ -1 & \text { if } x<0\end{array}\right.$ 


\subsection{Wavelets Auto-Regressive (WAR) Model}

Initially, the NAE series was standardized according to Equation 4.

$$
Z=\frac{X^{j}-\bar{X}}{\sigma}
$$

Where:

$\mathrm{Z}$ is the padronized variable;

$X^{j}$ is the annual variable NAE in a year $\mathrm{j}$;

$\bar{X}$ is the mean annual NAE of the historical series from 1931 to 2014;

$\sigma$ is the standard deviation of the Annual series.

The series decomposition in bands using Morlet Wavelet Function is performed in sequence, given by the Equation 5:

$$
\Psi_{0}(\eta)=\pi^{-1 / 4} e^{i \omega_{0} \eta} e^{-\eta^{2} / 2}
$$

With:

$$
\mathrm{w}_{0}=6 \text { e } \eta=\mathrm{t} / \mathrm{s}
$$

Where,

$\mathrm{t}$ is time;

$\mathrm{s}$ is the wavelet scale;

$\mathrm{w}_{0}$ is a non-dimensional frequency representing a wave modulated by a Gaussian envelope.

Three bands were used: one of high-frequency, of 1 to 10 years; one of medium frequency, from 11 to 33 years; and one of low-frequency of more than 33 years. Thus, the low-frequency band (Residual) was obtained by the Equation 6:

$N A E_{b b f}(i)=N A E(i)-N A E_{b a f}(i)-N A E_{b m f}(i)$

At where:

NAE (i) is the value of the average NAE in a year $i$;

$\mathrm{NAE}_{\text {baf }}(\mathrm{i})$ is the high-frequency band value ( 1 to 10 years) in a year $\mathrm{i}$;

$\mathrm{NAE}_{b m f}(\mathrm{i})$ is the medium frequency band value (11 to 33 years) in a year $\mathrm{i}$;

$\mathrm{NAE}_{\mathrm{bbf}}$ (i) is the low-frequency band value (from 33 years).

We say that $X_{t}, t Z \mathrm{~s}$ an autoregressive process of order $\mathrm{p}$ and we write $X_{t} A R(p)$ if we can write it: (Morettin, 2008) Equation 7.

$\mathrm{X}_{\mathrm{t}}=\phi_{0}+\phi_{1} \mathrm{X}_{\mathrm{t}-1}+\ldots+\phi_{\mathrm{p}} \mathrm{X}_{\mathrm{t}-\mathrm{p}}+\varepsilon_{\mathrm{t}}$

Where the estimation of the variable $\mathrm{Xt}$ for time $\mathrm{t}$ depends on a linear combination of $\mathrm{p}$ terms of the observed series, including the random term $\varepsilon(t)$ of white noise (estimation errors with normal distribution, mean zero, constant variance and non-correlated). The coefficients $\phi i$ are parameters that weight the values of $\mathrm{Xt}$, from the instant immediately preceding $\mathrm{t}-1$ to the farthest $\mathrm{t}-\mathrm{p}$, being determined through techniques to minimize error. 
With the decomposition of the bands from the transformed into wavelets, the signal was reconstructed by applying an autoregressive (AR) model to the high-, medium- and lowfrequency bands, considering that they are orthogonal as described by (Silveira, 2014). Given by Equation 8:

$z_{i}^{p}=\sum_{i=1}^{b} A R s_{b}(i)+A R s_{R(i)}(i)$

Where:

ARsb represents the autoregressive model of each high- and medium-frequency band.

ARsR represents the auto regressive model of the low-frequency band (residual).

The fundamental characteristic of an AR process is summarized in the fact that the current observation is correlated with the previous observation, that is, there is a significant correlation in the first lag, that is, between $\mathrm{Xt}$ and $\mathrm{Xt}-1$. Because $\mathrm{Xt}-1$ is also related to $\mathrm{Xt}-2$, there is indirectly a correlation in the second lag, between Xt and Xt-2. However, in the case of AR series, this correlation is implicit in the first lag (Moreira Junior and Caten, 2004).

\subsection{Model Evaluation: maximum likelihood}

After the composition of the normalized NAE series, an autoregressive model per band is used (Morettin, 2008). The error obtained during calibration is used in the projections. Through these, the mean and standard deviation of the errors are estimated, considering it as white noise. Further, the projection is obtained by summing the band's auto-regressive models.

After completion, the Wavelet Auto-Regressive (WAR) model is evaluated by applying the maximum likelihood estimated in a random sample $\mathrm{x}_{1}, \mathrm{x}_{2}, \ldots, \mathrm{x}_{\mathrm{n}}$ of the NAE time series, whose probability distribution depends on an unknown parameter $\theta$. The main objective is to find a point estimator $\mathrm{u}\left(\mathrm{x}_{1}, \mathrm{x}_{2}, \ldots, \mathrm{x}_{\mathrm{n}}\right)$ such that $\mathrm{u}\left(\mathrm{x}_{1}, \mathrm{x}_{2}, \ldots, \mathrm{x}_{\mathrm{n}}\right)$ is a "good" point estimate of $\theta$, where $\mathrm{x}_{1}, \mathrm{x}_{2}, \ldots, \mathrm{x}_{\mathrm{n}}$ are the observed values of the random sample.

Let $\mathrm{x}_{1}, \mathrm{x}_{2}, \ldots, \mathrm{x}_{\mathrm{n}}$ be a random sample of size $\mathrm{n}$ of the random variable $\mathrm{X}$ with density (or probability) function $\mathrm{f}(\mathrm{x} \mid \theta)$, with $\theta \in \Theta$, where $\Theta$ is the parametric space. The likelihood function of $\theta$ corresponding to the observed random sample is given by Equation 9:

$$
L(\theta, x)=\prod_{i=1}^{n} f_{Y_{i}}\left(x_{i} \vee \theta\right)
$$

The performance of projection of WAR in comparison to the climatology is calculated according to Equation 10:

$$
\text { Performance }=\left(\frac{L(\theta)_{\text {projection }}}{L(\theta)_{\text {climatology }}}\right)^{\frac{1}{n}}
$$

Where $\mathrm{n}$ is the number of years of the historical series used. When Performance $>1$, there was an improvement in the weather forecast. On the contrary, when Performance $<1$, there was a worsening of the projection.

\section{RESULTS AND DISCUSSIONS}

\subsection{Trend Analysis}

Trend analysis of NAE values was performed to detect if there is a trend and, if there is one, whether it is positive or negative. Figure 4 shows the results for the tests applied in historical data. Values above zero indicate the positive deviations (positive anomaly), where 
the annual NAE exceeded the historical average, and values below zero indicate the periods of negative deviation (negative anomaly), where NAE was lower than the mean historical information.

Analyzing the results of the moving average for the stations of the Southeastern Subsystem, it is possible to observe low-frequency variability with long periods of three decades. The Mann-Kendall test showed a positive trend in the NAE series. In the Northeastern Subsystem, a decadal variability is observed through the moving averages. The utilization of the Southern Subsystem showed a significant positive trend with year-on-year behaviour, in most of the series, the Mann-Kendall method shows a tendency of NAE increase. The utilizations of the Northern Subsystem presented anomalies between the ranges of -1 to 1 . Moving averages presented low-frequency decadal variability. The decades of the $40 \mathrm{~s}$ and $80 \mathrm{~s}$ were more energetic. The series showed no significant trend.
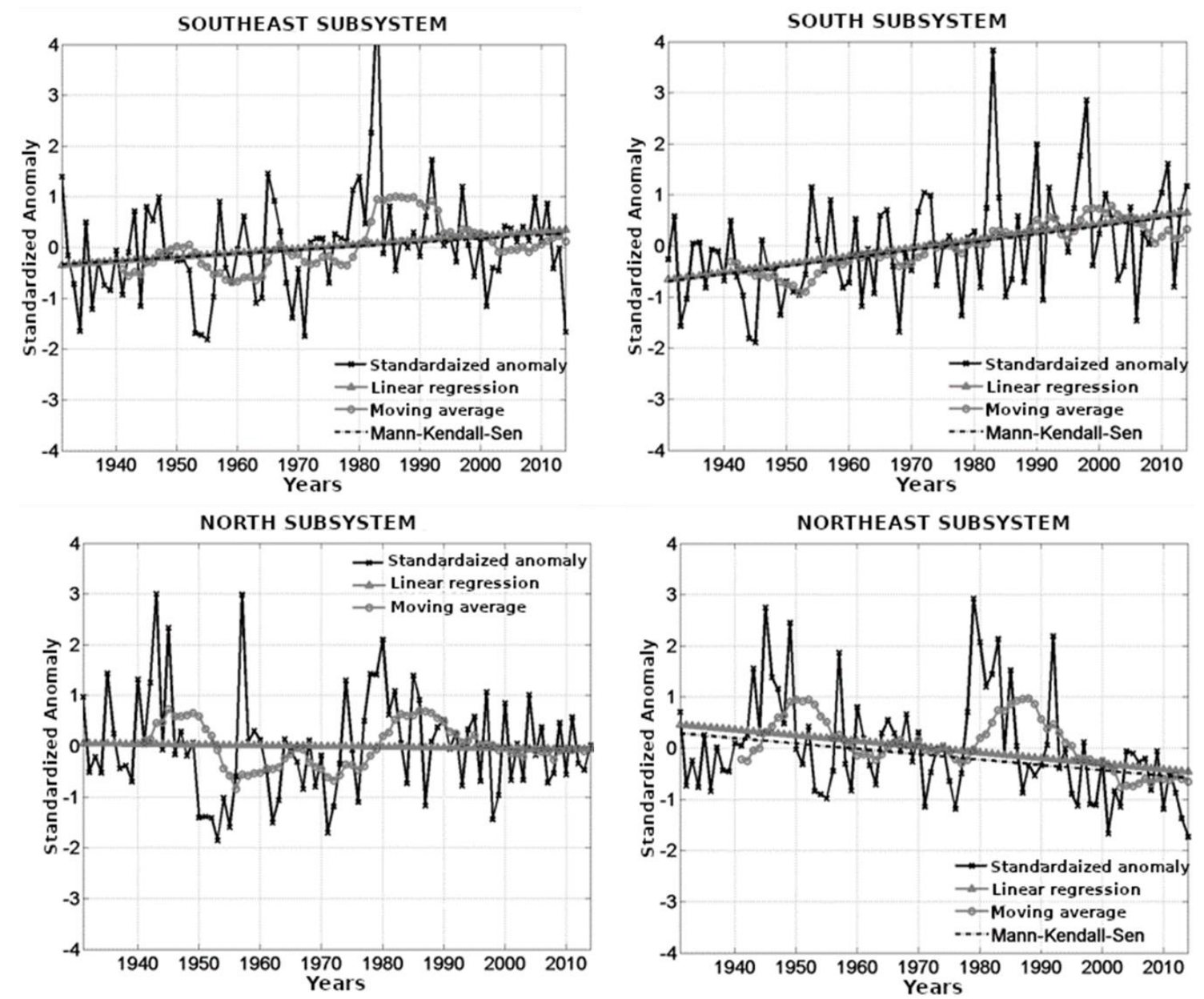

Figure 4. Trend analysis.

The trend analysis detected that thirteen out of eighteen basins analyzed in this study presented a significant trend, Mann-Kendall hypothesis test different from zero. Among these, nine registered a positive trend and four showed a negative trend. The positive trend group is composed of Atlântico Sul, Atlântico Sudeste, Iguaçu, Jacuí, Paraguai, Paraná, Paranapanema, Tiete and Uruguai Basins. Most of these basins belong to the Southern and Southeastern /Midwestern Subsystem. For the basins of the São Francisco, Paranaíba, Paraíba do Sul, Grande, and Amazonas Basins, the Mann-Kendall test showed no tendency, and for the Parnaíba, Tocantins, Doce and Atlântico Leste basins, the test presented a negative trend. Figure 5 and Table 1 show the results for the studied basins. 


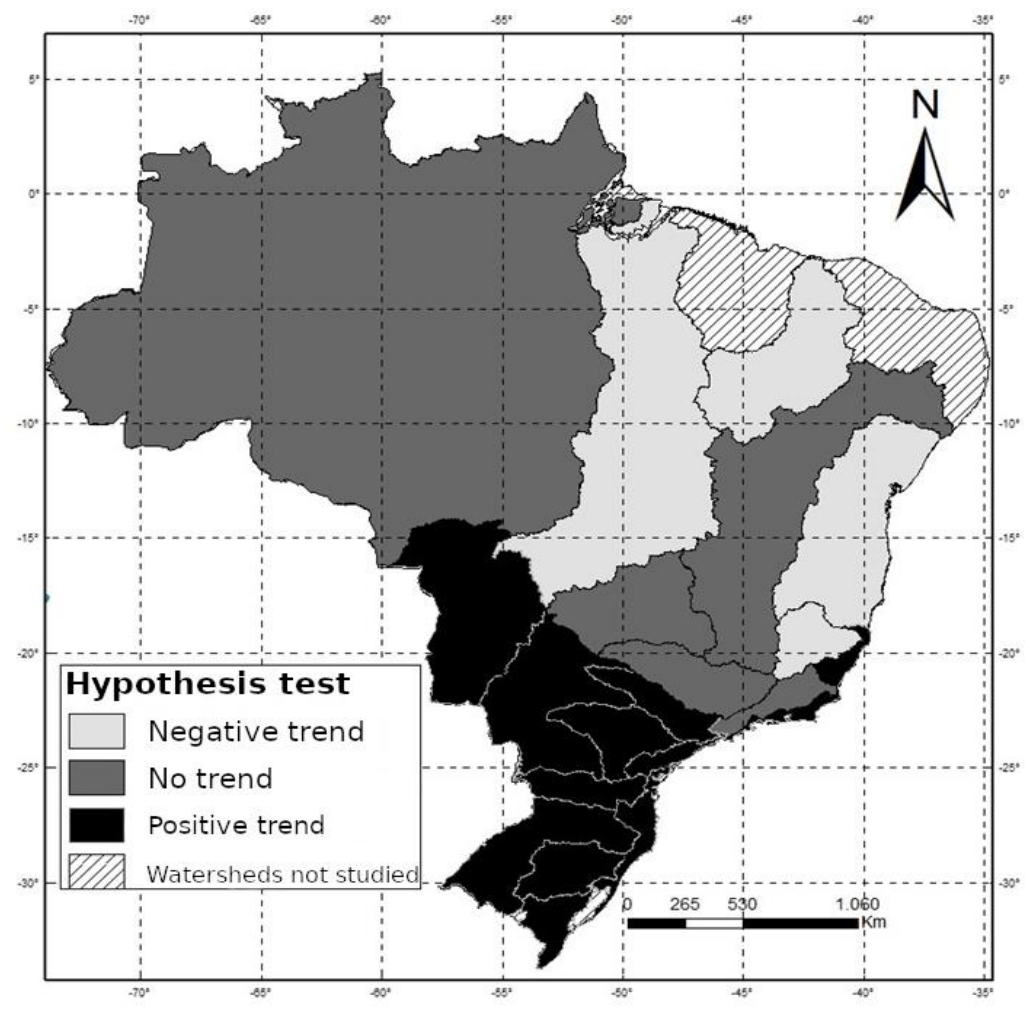

Figure 5. NAE Trend analysis for each basin.

Table 1. Mann-Kendall Test.

\begin{tabular}{cc}
\hline Basin & Trend \\
\hline Parnaíba, Tocantins, Doce and Atlântico Leste & Negative Trend (-1) \\
São Francisco, Paranaíba, Paraíba do Sul, Grande, and Amazonas & No Trend (0) \\
$\begin{array}{c}\text { Atlântico Sul, Atlântico Sudeste, Iguaçu, Jacuí, Paraguai, Paraná, } \\
\text { Paranapanema, Tiete and Uruguai }\end{array}$ & Positive Trend (1) \\
\hline
\end{tabular}

The analysis of the wavelet transformation for the study basins is presented in Tables 2, 3 and 4 and Figures 6 (a), 6 (b) and 6 (c) in the form of maps, showing the spatial distribution of variance proportions explained by the high-, medium- and low frequencies, respectively. With this information, it is possible to realize that a large part of the variance in all the basins is explained by the high-frequency band, less for that of Paraguai, and that, in general, the medium- and low-frequency phenomena are more relevant to the basins which are more embedded in the central part of the continent.

Table 2. High-Frequency (1 to 10 years).

\begin{tabular}{cc}
\hline Basins & Variance Percentage $\left(\boldsymbol{\sigma}^{2}\right)$ \\
\hline------- & $\sigma^{2}<10 \%$ \\
Paraguai & $10 \% \leq \sigma^{2}<20 \%$ \\
$\begin{array}{c}\text { Parnaíba, Tocantins, Doce, Atlântico Leste São Francisco, Paranaíba, Paraíba } \\
\text { do Sul, Grande, Amazonas Atlântico Sul, Atlântico Sudeste, Iguaçu, Jacuí, } \\
\text { Paraná, Paranapanema, Tiete and Uruguai }\end{array}$ & $20 \% \sigma^{2}<30 \%$ \\
\hline
\end{tabular}


Table 3. Mean Frequency (11 to 33 years).

\begin{tabular}{cc}
\hline Basins & Variance Percentage $\left(\boldsymbol{\sigma}^{2}\right)$ \\
\hline Paranaíba, Grande, Paraíba do Sul & $\sigma^{2}<10 \%$ \\
Paraguai, Paraná & $10 \% \leq \sigma^{2}<20 \%$ \\
Tocantins, Parnaíba, Paranapanema, Atlântico Sul & $20 \% \leq \sigma^{2}<30 \%$ \\
Doce, Atlântico Leste São Francisco, Amazonas, Atlântico Sudeste, & $\sigma^{2} \geq 30 \%$ \\
\hline Iguaçu, Jacuí, Tiete and Uruguai, & \\
\hline
\end{tabular}

Table 4. Low-Frequency (33 to 84 years).

\begin{tabular}{cc}
\hline Basins & Variance Percentage $\left(\boldsymbol{\sigma}^{2}\right)$ \\
\hline Tiete, Paranapanema, Atlântico Sul, Uruguai & $\sigma^{2}<10 \%$ \\
Parnaíba, Doce, Atlântico Leste, Paraíba do Sul, Amazonas, & $10 \% \leq \sigma^{2}<20 \%$ \\
Atlântico Sudeste, Iguaçu, Jacuí and Paraná & $20 \% \leq \sigma^{2}<30 \%$ \\
Tocantins, São Francisco, Paraguai, Paranaíba, Grande & $\sigma^{2} \geq 30 \%$ \\
\hline------- &
\end{tabular}
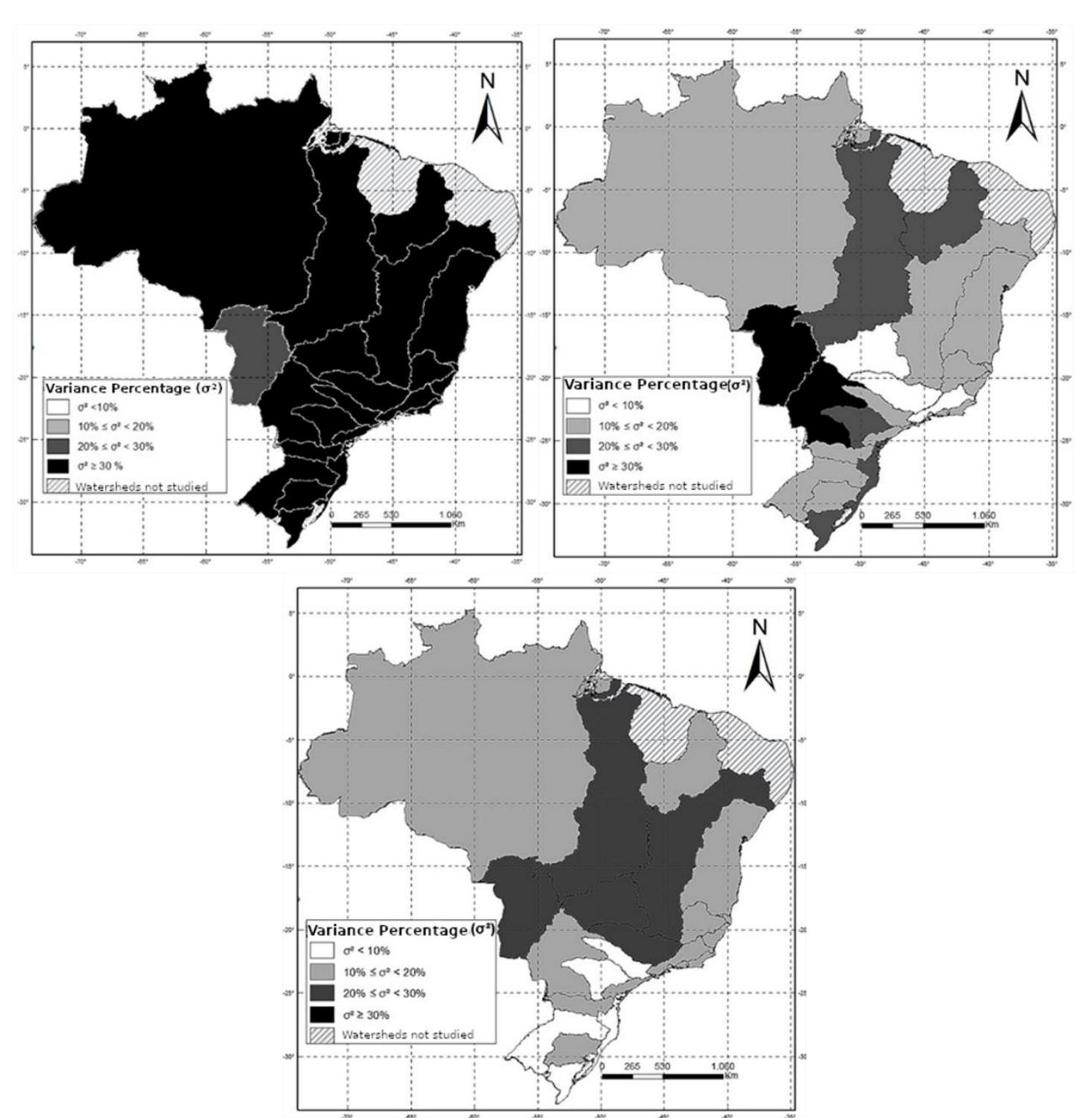

Figure 6. Spatial distribution of variance proportions explained by bands of: (a) highfrequency (1 to 10 years); (b) mean frequency (11 to 33 years) and (c) low-frequency - residue (34 to 84 years). 
Wavelet analysis for the subsystems from the decomposition of the frequency bands is presented in Figure 7. The Southeastern/Midwestern Subsystem presented significant variability. The low-frequency band (Residual) remained approximately constant until the 1960 period. In the period between 1970 and 2000, it presented its most energetic phase, presenting a possible relation with the AMO cold phase. The Northeastern Subsystem presented variation in the low-frequency band (Residual) of approximately 30 years. In the period 1931 to 1950, the time series shows the values of the standardized NAE index coincident with the PDO periods in the cold phase. In the Southern Subsystem, the low-frequency band (Residual) showed oscillation in a long period, changing phase around 1970, with a considerable peak in the decade of 1990. The period between 1970 to 2000 coincided with the AMO cold phase. The Northern Subsystem showed significant variability with maximum values between 1945 and 1980 in the bands, in those years the three bands were at coincident peak. In the Northern Subsystem and Southeastern Subsystem, there is a periodic oscillation in the low-frequency band with a period of approximately 30 years. This behaviour may be related to the PDO, where the hot phase coincides with the fewer periods and the cold phase with the more energetic periods.
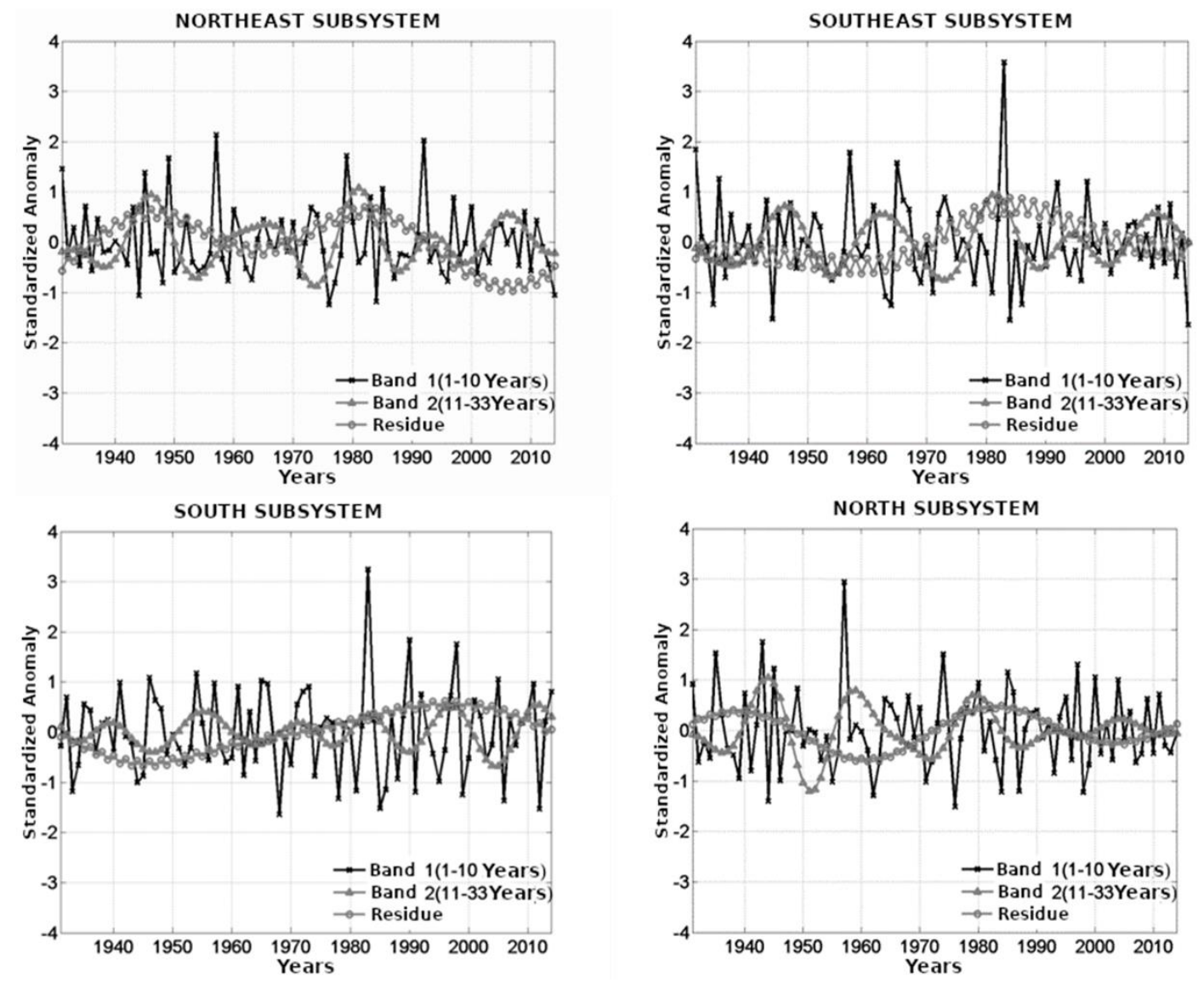

Figure 7. Wavelet analysis.

\subsection{Performance and Evaluation of the WAR model from 2005 to 2014}

The evaluation of the model is to verify if it is better than the climatology in the analyzed 10 years. It was performed by comparing the statistical distribution of the median of the scenarios generated by the WAR model compared to the statistical distribution of the 10 years evaluated (2005 to 2014). This NAE analysis is done concerning climatology. From then on, it obtains the likelihood ratio. Values greater than 1 indicate that the model was successful concerning climatology. Table 5 and Figure 8 show the likelihood ratio obtained by Equation 9. The model showed an improvement in the climatology for the Grande, Paranaíba, 
Paranapanema, São Francisco, Tocantins, Doce, Uruguay, Jacuí, Paraná, Tietê, Iguaçu and Paraíba do Sul Basins. However, for the Paraguai, Parnaíba, Amazonas, Atlântico Sul, Atlântico Suldeste and Atlântico Leste the model showed a worsening in the projection concerning Climatology.

Table 5. Likelihood Ratio- Performance.

\begin{tabular}{cc}
\hline Basin & Performance \\
\hline Paraguai, Paranaíba, Amazonas, Atlântico Sul, Atlântico Sudeste and & \\
Atlântico Leste, & $<1$ \\
Grande, Parnaíba, Paranapanema, São Francisco, Tocantins, Doce, Jacuí, \\
Paraná, Tiete, Uruguai, Iguaçu and Paraíba do Sul. & $>1$ \\
\hline
\end{tabular}

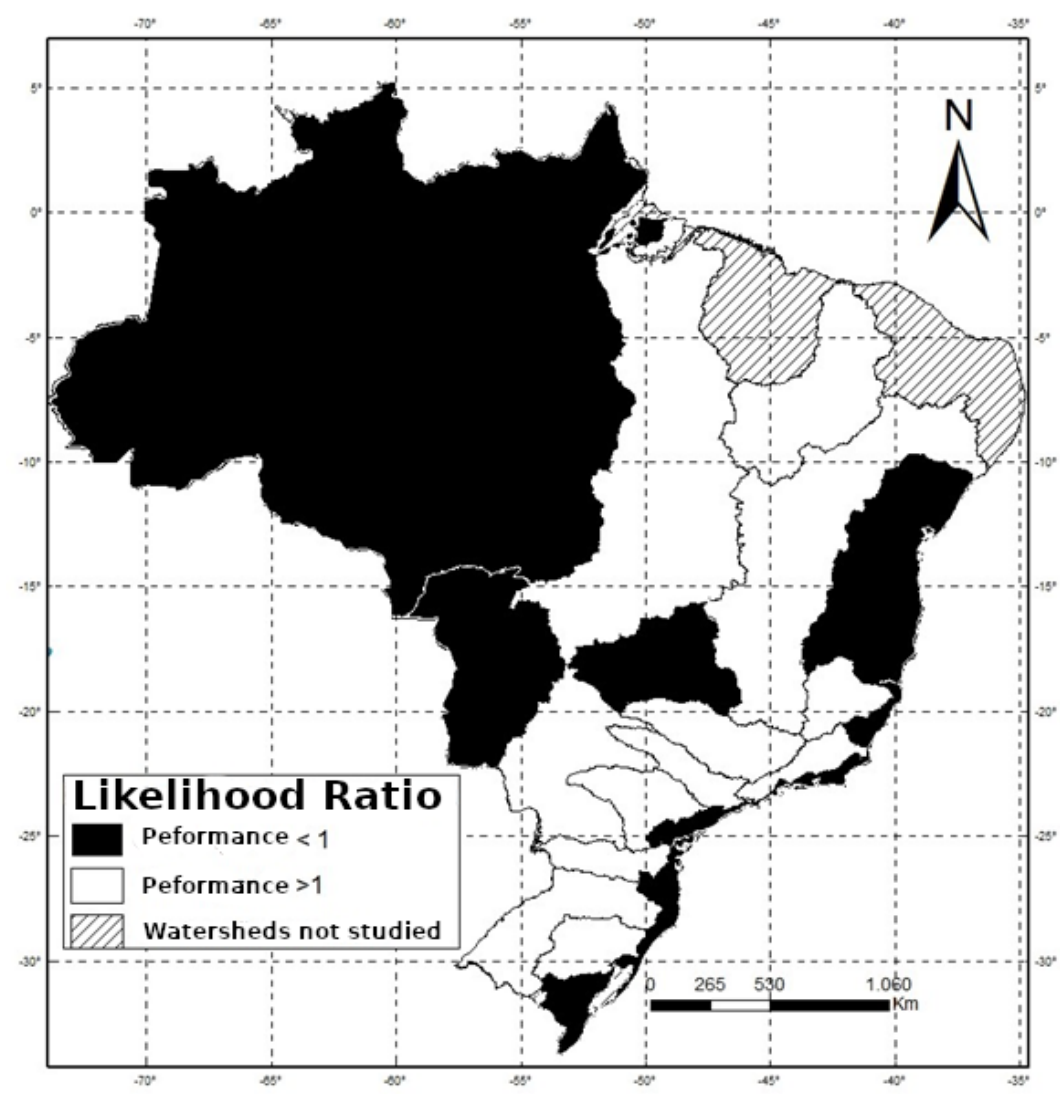

Figure 8. Likelihood ratio obtained between the WARs model and climatology for the SIN basins.

\subsection{Projection-based on the Medium Frequency Band}

As seen previously, the band of medium frequencies presents different significance for the analyzed basins. The Southeastern/Midwestern Subsystem presented significant variability in the 1980s. The low-frequency band remained constant until the 1960 period and in the period of its more energetic phase, between 1970 and 2000, it presented a direct correlation with the AMO's cold phase. The wavelets showed for Northeastern Subsystem that the years between 1940 and 1950 and in approximately 1980 are the periods responsible for a significant value in the variability of NAE and are their most energetic periods. The Northeastern subsystem presented variation in the low-frequency band of approximately 30 years. In the period 1931 to 1950, the time series shows the values of the standardized NAE index coincident with the periods of ODP in the cold phase. 
In the Southern Subsystem, the low-frequency band (Residual) showed oscillation in a long period, changing phase around 1970, with a considerable peak in the decade of 1990. The period between 1970 to 2000 coincided with the period of AMO in the phase cold. The Northern Subsystem showed significant variability around 1945 and 1980 in the bands; in those years the three bands were at coincident peak. The medium frequency band (11 to 33 years - Band 2) showed a gradual reduction of the amplitude of variation throughout the series. In the Northern and Southeastern Subsystem, there is a periodic oscillation in the low- frequency band with a period of approximately 30 years. It is possible that this behaviour is related to the PDO where the hot phase coincides with the less energetic periods and the cold periods coincide with the more energetic periods. It is also observed in the four graphs, a periodic oscillation in the medium frequency band with a period between 10 and 20 years.

\subsection{Projection: 2015 to 2024}

Figure 9 shows the NAE projections employing the WAR model for the period from 2015 to 2024 for the SIN basins. The Iguaçu and Atlântico Sudeste Basins indicate a greater possibility of a reduction in NAE by 2020 , while Parnaíba and Tocantins present a possible increase. These signals may be associated with the AMO and PDO signals.
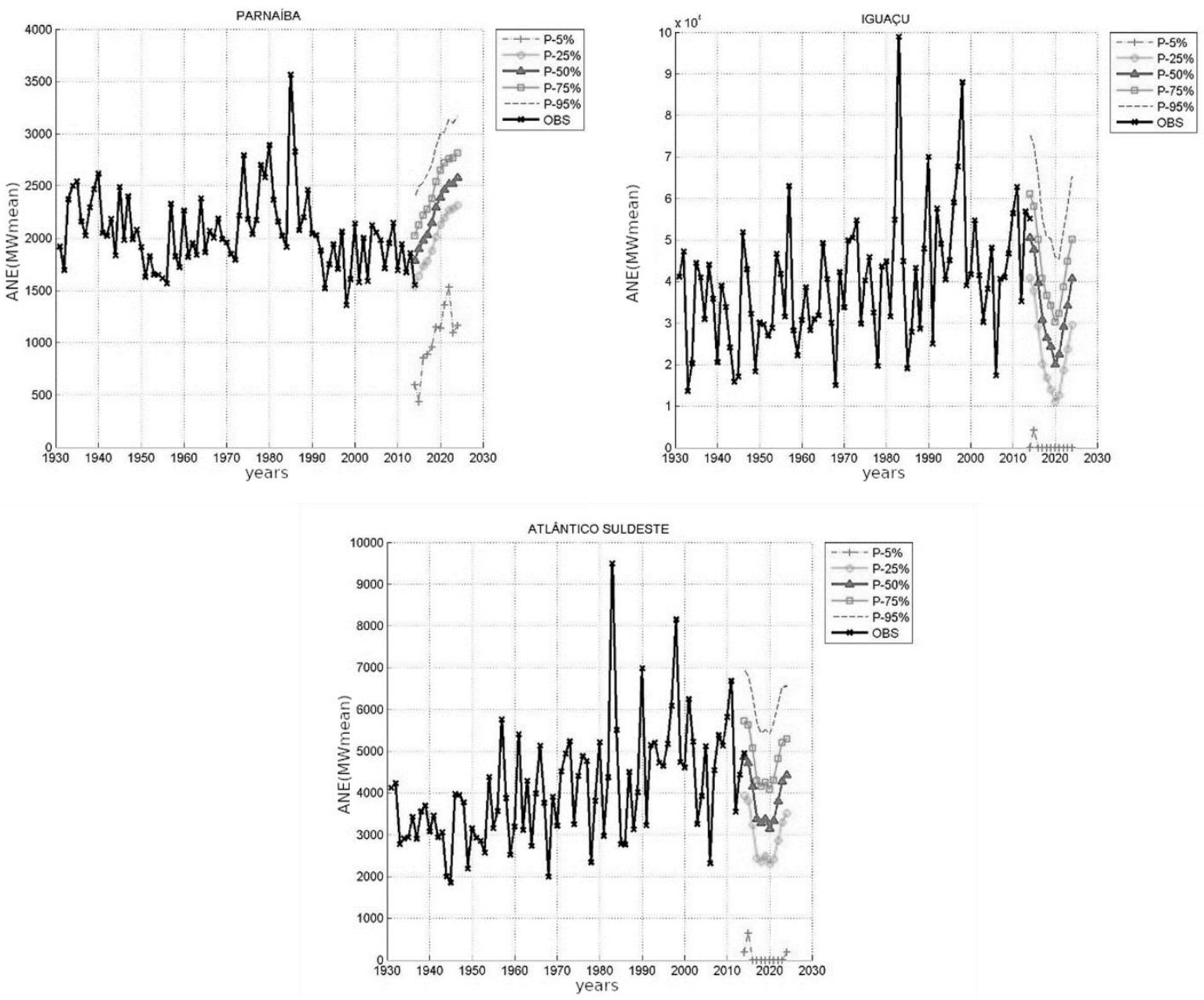

Figure 9. Projections of the WAR model for the period from 2015 to 2024.

\section{CONCLUSIONS}

The basins of the Atântico Sul, Atlântico Suldeste, Iguaçu, Jacuí, Paraguai, Paraná, Paranapanema, Tietê and Uruguai showed a positive trend, according to the method of Mann 
Kendall. It is observed that these basins predominantly belong to the Southern and Southeastern $\backslash$ Midwestern Subsystems. The basins of Amazonas, Grande, Paraíba do Sul, Paranaíba and São Francisco presented no significant trend. While the other basins studied, Atlântico Leste, Doce, Parnaíba and Tocantins presented a negative trend of NAE. The Southern and Southeast/Midwestern Subsystems indicated a positive trend and the Northeastern Subsystem showed a negative trend, while the Northern Subsystem presented a non-significant trend.

Güntner et al. (2007) analyzed monthly flow data and the capacity of the ENSO phenomenon, thus explaining the variability of the hydrological regime of the Southern American rivers and verified a significant correlation between ENSO variability and streamflow in most of South America. As the NAE is a direct product of the flow, this variability can be observed in this study. The patterns of identified variations of NAEs suggest a correlation with PDO.

\section{ACKNOWLEDGEMENTS}

To the research group Climate and energy planning (CLIPE). To the International Integration University of Afro-Brazilian Lusophony (UNILAB), to the Coordination of Improvement of Higher Level Personnel (CAPES), the Federal University of Ceará (UFC), the Cearense Foundation of Meteorology and Water Resources (FUNCEME).

\section{REFERENCE}

ANEEL. Banco de Informações de Geração. Capacidade de Geração do Brasil. Available at: www.aneel.gov.br. Access: 07 Sep. 2017.

ANDREOLI, R. V.; KAYANO, M. T. ENSO - related rainfall anomalies in South America and associated circulation features during warm and cold Pacific Decadal Oscillation regimes. International Journal Climatology. v. 25, n. 15, p. 2017-2030, 2005. https://doi.org/10.1002/joc.1222

BURN, D. H.; ELNUR, M. A. H. Detection of hydrologic trends and variability. Journal of Hydrology, v. 255, n. 1-4, p. 107-122, 2002. https://doi.org/10.1016/S00221694(01)00514-5

CANE, M. A. Decadal predictions in demand. Nature Geoscience, p. 231-232, 2010. https://doi.org/10.1038/ngeo823

CARVAlHO, L. M. V.; JONES, C.; LIEBMANN, B. The South Atlantic Convergence Zone: persistence, intensity, form, extreme precipitation and relationships with intraseasonal activity. Journal of Climate, v. 17, p. 88-108, 2004.

DANTAS, L. G. et al. Oscilação Decadal do Pacífico e Multidecadal do Atlântico no clima da Amazônia Ocidental. Revista Brasileira de Geografia Física, v. 5, n. 3, p. 600-611, 2012.

EMPRESA DE PESQUISA ENERGÉTICA. Anuário estatístico de energia elétrica 2011. Rio de Janeiro, 2011.

GÜNTNER, A.; STUCK, J.; WERTH, S.; DÖLL, P.; VERZANO, K.; MERZ, B. A global analysis of temporal and spatial variations in continental water storage. Water Resources Research, v. 43, n. 5, 2007. https://doi.org/10.1029/2006WR005247 
KODAMA, Y. M. Large-scale common features of subtropical precipitation zones (the Baiu Frontal Zone, the SPCZ, and the SACZ). Part II: Conditions for generating the STCZs. Journal of the Meteorological Society of Japan. v. 71, n. 2, p. 581-610, 1993. https://doi.org/10.2151/jmsj1965.70.4_813

KWON, H. H.; LALL, U.; KHALIL, A. F. Stochastic simulation model for nonstationary time series using an autoregressive wavelet decomposition: Applications to rainfall and temperature. Water Resources Research, v. 43, n. 5, 2007. https://doi.org/10.1029/2006WR005258

LÁZARO, Y. M. C. Mudança climática no nordeste do Brasil, Amazônia e Bacia do Prata: avaliação dos modelos do IPCC e cenários para o século XXI. 2011. 89 f. Dissertação (Mestrado em Engenharia Civil: Recursos Hídricos) - Centro de Tecnologia, Universidade Federal do Ceará, Fortaleza, 2011.

MANTUA, N. J. et al. A Pacific Interdecadal Climate Oscillation with impacts on salmon production. Bulletin of the American Meteorological Society, v. 78, p. 1069-1079, 1997. https://doi.org/10.1175/1520-0477(1997)078\%3C1069:APICOW\%3E2.0.CO;2

MOREIRA JUNIOR, F. de J. M.; CATEN, C, S. Estudo sobre o efeito da Autocorrelação de Modelos AR(1) no Controle Estatístico de Processo. In: ENCONTRO NACIONAL DE ENGENHARIA DE PRODUÇÃO, 24., 2004, Florianópolis. Anais[...] Florianópolis: ABEPRO, 2004.

MORETTIN, P. A. Econometria financeira: um curso de séries temporais financeira. São Paulo: Edgard Blücher, 2008.

NASCIMENTO JÚNIOR, L.; SANT'ANNA NETO, J. L. Contribuição aos estudos da precipitação no estado do Paraná: a oscilação decadal do Pacífico - ODP. Raega - O

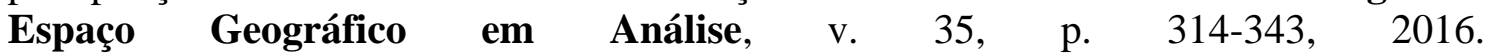
http://dx.doi.org/10.5380/raega.v35i0.42048

OPERADOR NACIONAL DO SISTEMA ELÉTRICO. Programa mensal de operação PMO: relatório de previsão de vazões e geração de cenários de afluências. 2012. Available at: http://www.ons.org.br/conheca_sistema/o_que_e_sin.aspx. Access: 15 May 2016.

RAMOS, T. P. Modelo individualizado de usinas hidrelétricas baseado em técnicas de programação não linear integrado com o modelo de decisão estratégica. 2011. Dissertação (Mestrado em Energia) - Universidade Federal de Juiz de Fora, Juiz de Fora, 2011.

SILVA, D. F. Influência Interdecadal (ODP e OMA) nas Cotas do Rio São Francisco. Revista Brasileira de Geografia Física, v. 6, n. 6, p. 1529-1538, 2013.

SILVA, D. F.; GALVÍNCIO, J. D. et al. Influência da variabilidade climática e da associação de fenômenos climáticos sobre sub-bacias do rio São Francisco. Revista Brasileira de Ciências Ambientais, n. 19, p. 46-56, 2011.

SILVEIRA, C. S. Modelagem integrada de meteorologia e recursos hídricos em múltiplas escalas temporais e espaciais: aplicação no Ceará e no setor hidroelétrico brasileiro. 2014. 352 f. Tese (Doutorado em Recursos Hídricos) - Centro de Tecnologia, Universidade Federal do Ceará, Fortaleza, 2014.

TORRENCE, C.; COMPO, G. P. A Practical Guide to Wavelet Analysis. Bulletin of American Meteorological Society, v. 79, p. 61-78, 1998. https://doi.org/10.1175/15200477(1998)079\%3C0061:APGTWA\%3E2.0.CO;2 


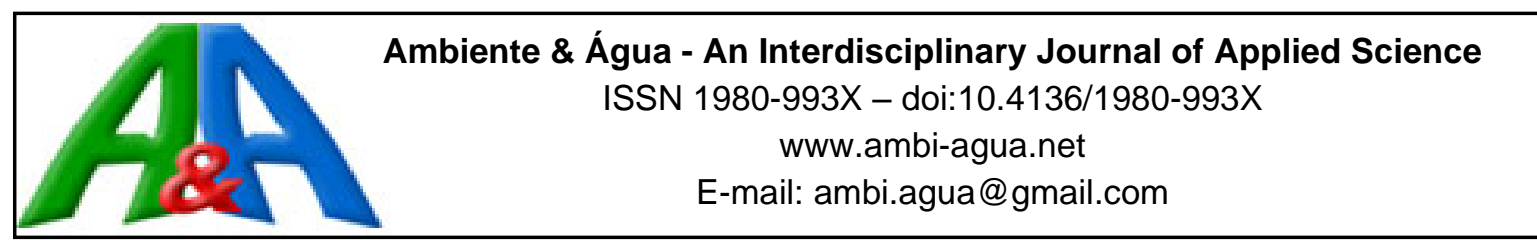

\title{
Physical fractions of organic matter and mineralizable soil carbon in forest fragments of the Atlantic Forest
}

\author{
ARTICLES doi:10.4136/ambi-agua.2601
}

Received: 18 Jun. 2020; Accepted: 28 Sep. 2020

\author{
Jefferson Matheus Barros Ozório ${ }^{1 *}$ (D) Jean Sérgio Rosset ${ }^{1}$; \\ Jolimar Antonio Schiavo ${ }^{2}$; Camila Beatriz da Silva Souza ${ }^{1}$; \\ Paulo Guilherme da Silva Farias ${ }^{2}$; Naelmo de Souza Oliveira ${ }^{2}$; \\ Roniedison da Silva Menezes ${ }^{2}$; Eloi Panachuki² ${ }^{2}$
}

\begin{abstract}
${ }^{1}$ Departamento de Gestão Ambiental. Universidade Estadual de Mato Grosso do Sul (UEMS), BR-163, Km 20,2, CEP: 79980-000, Mundo Novo, MS, Brazil. E-mail: rosset@uems.br, camilabeatrizss@ hotmail.com ${ }^{2}$ Departamento de solos. Universidade Estadual de Mato Grosso do Sul (UEMS), Rodovia Graziela Barroso, Km 12 Zona Rural, caixa postal 25, CEP: 79200-000, Aquidauana, MS, Brazil. E-mail: schiavo@uems.br, pauloguilhermesf@hotmail.com, naelmo-95@hotmail.com, roniedison1@ hotmail.com, eloip@uems.br *Corresponding author. E-mail: ozorio.jmb@outlook.com
\end{abstract}

\begin{abstract}
This study determined the physical granulometric fractionation evaluated the mineralizable carbon within and around forest fragments of the Atlantic Forest biome located in the state of Paraná. Soil samples were collected at three three internal points of the fragments: the edge (E), the half radius (HR) and the center (CF); and one point in no-tillage system (NTS) areas around the fragments, in four replicates. The contents of total organic carbon (TOC), particulate fraction carbon (C-POM) and mineral fraction (C-MOM) were determined, and the \%POM and $\% \mathrm{MOM}$ and the stocks of POM (StockPOM) and MOM (StockMOM) were calculated, in addition to the indices: carbon stock index (CSI), lability (L), lability index (LI) and carbon management index (CMI), also evaluating $\mathrm{CO}_{2}$ emission, daily and accumulated. The highest TOC levels were observed in the CF point. The highest C-POM contents were observed in the $\mathrm{E}$ and $\mathrm{CF}$ points of fragment 1 , in the $\mathrm{CF}$ point of fragment 2 , and the highest C-MOM contents were expressed in the $\mathrm{CF}$ points of both fragments. $\mathrm{CMI}$ showed a distinct pattern among the fragments. The NTS areas showed lower $\mathrm{C}-\mathrm{CO}_{2}$ emissions, with $39.8 \%$ and $28.3 \%$ less total emission compared to $\mathrm{CF}$. The results of physical granulometric fractionation show the $\mathrm{CF}$ point favors the quality of SOM and the mineralizable carbon analysis indicated that the conversion of native areas into NTS compromises soil microbial activity.
\end{abstract}

Keywords: carbon management, environmental assessment, soil quality.

\section{Frações físicas da matéria orgânica e carbono mineralizável do solo em fragmentos florestais da Mata Atlântica}

\section{RESUMO}

O objetivo do presente trabalho foi determinar o fracionamento físico-granulométrico e avaliar o carbono mineralizável no interior e ao entorno de fragmentos florestais do bioma Mata Atlântica localizados no estado do Paraná. As amostras de solo foram coletas em três de três pontos internos dos fragmentos: borda (BO), metade do raio (MR) e centro (CF) e um ponto 
em áreas de sistema plantio direto (SPD) no entorno dos fragmentos, em quatro repetições. Foram determinados os teores de carbono orgânico total (COT), carbono da fração particulada (C-MOP) e da fração mineral (C-MOM), sendo calculados as \%MOP e \%MOM e os estoques de MOP (Est. MOP) e de MOM (Est. MOM), além dos índices: índice de estoque de carbono (IEC), labilidade (L), índice de labilidade (IL) e índice de manejo de carbono (IMC), avaliando ainda a emissão de $\mathrm{CO}_{2}$, diária e acumulada. Os maiores teores de COT foram observados no ponto $\mathrm{CF}$. Os maiores teores de $\mathrm{C}$-MOP foram observados nos pontos $\mathrm{BO}$ e $\mathrm{CF}$ do fragmento 1, no ponto $\mathrm{CF}$ do fragmento 2, e os maiores teores de $\mathrm{C}-\mathrm{MOM}$ foram expressos no ponto $\mathrm{CF}$ de ambos os fragmentos. O IMC apresentou padrão distinto entre os fragmentos. As áreas de SPD apresentaram menor emissão de $\mathrm{C}-\mathrm{CO}_{2}$, com $39,8 \%$ e $28,3 \%$ menos emissão total em relação ao $\mathrm{CF}$. Os resultados do fracionamento físico-granulométrico mostram o ponto $\mathrm{CF}$ favorece a qualidade da MOS e a análise de carbono mineralizável indicou que a conversão de áreas nativas em SPD compromete a atividade microbiana do solo.

Palavras-chave: avaliação ambiental, manejo de carbono, qualidade do solo.

\section{INTRODUCTION}

The effect of anthropization on the Brazilian Atlantic Forest biome has generated several impacts on the landscape in general, among them, the increase in forest fragmentation stands out (Warburton, 1997). Forest fragments were defined by Viana and Pinheiro (1998) as areas of natural vegetation interrupted by natural barriers (mountains, rivers, lakes, among others), or anthropic barriers (roads, agricultural activities, cities), which interfere with the flow of fauna, pollen and seed dispersal.

Forest fragmentation is a phenomenon distributed throughout large natural areas, shaping the landscape in general (Viana et al., 1997), restricting the survival of biodiversity to these areas, making the remaining fragments extremely important for the conservation biology (Warburton, 1997). The consequence of forest fragmentation is mainly reflected in the decrease, and even in the extinction of fauna (Pereira and Neves, 2007; Laurance and Vasconcelos, 2009) and flora (Souza et al., 2015). A major problem when thinking about forest fragments is the non-connectivity between them, which would allow greater survival of species due to the greater effectiveness of gene flow (Viana and Pinheiro, 1998).

With the forest fragmentation of Brazilian biomes, the species are exposed to physical and biotic changes, causing the so-called "edge effect" in the fragments. This effect occurs near the edge of the fragment, where there is greater sensitivity to external agents, making more noticeable the various forms of changes, such as vegetation variation, with changes in edaphic attributes over time, due to several regional factors (Malchow et al., 2017).

Changes in edaphic attributes in forest fragments as a function of the edge effect are not yet well defined, and may differ from one region to another (Primack and Rodrigues, 2001). Thus, there is no defined pattern for the exact point at which microclimatic, vegetation and soil changes on the edge effect can be noticeable by entering the forest fragment, as it depends on numerous factors (Kapos, 1989).

Barros and Fearnside (2016), studying carbon stock (C) on the edges of forest fragments in the Amazon biome, reported an increase in soil $\mathrm{C}$ stock in the first meters entering the fragments, when compared to areas of 300 meters within these fragments. However, studies that present the effects that fragmentation and edge effect can cause in $\mathrm{C}$ and in the edaphic characteristics of Brazilian biomes are still incipient in the literature (Ozório et al., 2019).

Soil organic matter (SOM) studies based on $\mathrm{C}$ contents are sensitive in identifying changes in soil management and mainly in vegetation modifications (Souza et al., 2019; Ferreira et al., 2020). The fact that the $C$ content is immediately changed when the vegetation is modified occurs by the change in the input of SOM by the deposition of dry mass (Lal, 2018; Assunção

Rev. Ambient. Água vol. 15 n. 6, e2601 - Taubaté 2020 
et al., 2019).

Another way to evaluate the edaphic quality and possible changes caused by the management and alteration of natural vegetation is the fractionation of SOM, mainly due to its high diversity in oxidation state, chemical composition, size, lability and recalcitrance (Rangel and Silva, 2007). Thus, physical granulometric fractionation of SOM, which quantifies labile and recalcitrant fractions, is an important environmental assessment tool (Rosset et al., 2019b). In addition to the forms of fractionation, the evaluation of soil mineralizable carbon is another variable that contributes to evaluate soil biological quality (Borges et al., 2016; Rosset et al., $2019 \mathrm{a}$ ), through the emission of $\mathrm{CO}_{2}$, product of the activity of microorganisms that decompose SOM (Rosset et al., 2019b).

Thus, studies evaluating soil quality with analytical techniques that are sensitive in identifying changes in soil and vegetation management are of great scientific importance and are also important for the conservation of existing forest fragments. The hypothesis of the work is that the interior of the forest fragments present quantity and quality of the MOS, as they do not suffer from a possible edge effect. Therefore, this study determined the labile and recalcitrant fractions of carbon through physical granulometric fractionation, and evaluated the mineralizable carbon within forest fragments and in areas managed around forest fragments of the Atlantic Forest biome.

\section{MATERIAL AND METHODS}

\subsection{Location, Climate, Soil and History of Study Areas}

Soil samples were collected from two forest fragments located in the municipality of Terra Roxa, western Paraná state, Brazil (Figure 1, Table 1). The vegetation of the two fragments is of Atlantic Forest - Semideciduous Seasonal Forest (Campos and Silveira Filho, 2010), the two fragments are rectangular, with a proximity of $50 \mathrm{~m}$ from one another.

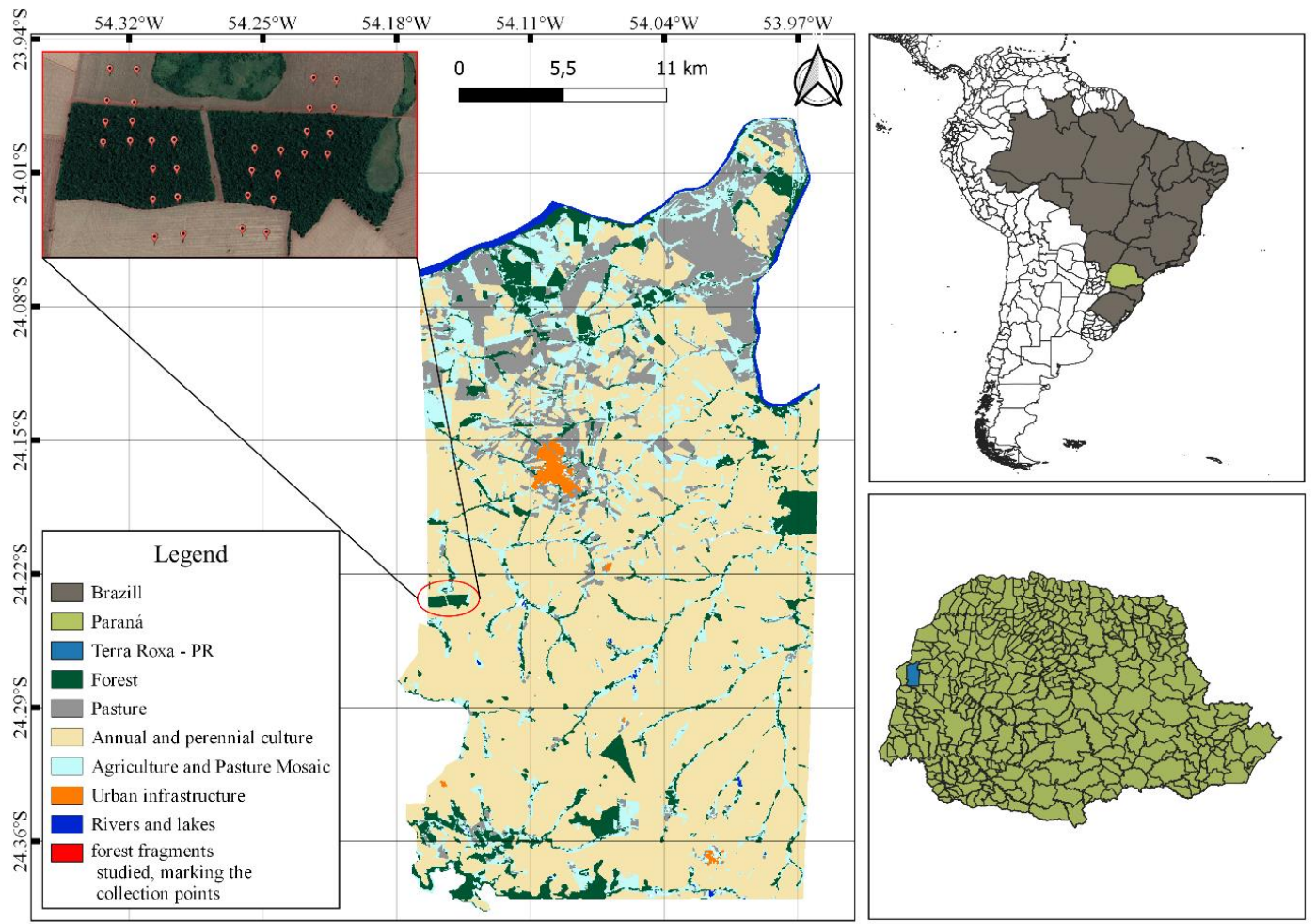

Figure 1. Location map with the main land-use activities, assessed fragments and sampling points, in which each sampled point represents a repetition, in the municipality of Terra Roxa - PR. 
Table 1. Descriptions of the areas of the forest fragments evaluated.

\begin{tabular}{|c|c|}
\hline Evaluated fragments & Description \\
\hline Fragment 1 & 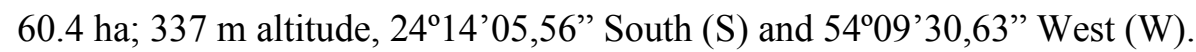 \\
\hline Fragment 2 & 69.1 ha; $338 \mathrm{~m}$ altitude, $24^{\circ} 14^{\prime} 04,37^{\prime \prime}$ South (S) and $54^{\circ} 08^{\prime} 51,89^{\prime \prime}$ West (W). \\
\hline
\end{tabular}

The climate of the area is subtropical (Cfa), according to Köppen classification (Caviglione et al., 2000). According to the detailed survey of soils of Paraná state (Bhering et al., 2007), the study areas are under typical Eutrophic Red Latosol (Santos et al., 2018), very clayey texture (58.0, 249.8, 692.2 $\mathrm{g} \mathrm{kg}^{-1}$ of sand, silt and clay, respectively in Fragment 1, and 57.6, 242.4, $701.0 \mathrm{~g} \mathrm{~kg}^{-1}$ of sand, silt and clay, respectively in Fragment 2) (Santos et al., 2018), and the chemical characterization of the studied points is presented in Table 2.

Table 2. Chemical characterization of the studied points in Fragments 1 and 2 and in the surrounding NTS areas.

\begin{tabular}{ccccc}
\hline Determinations & $\begin{array}{c}\text { Points E, HR and CF of } \\
\text { Fragment 1 }\end{array}$ & $\begin{array}{c}\text { Points E, HR and CF of } \\
\text { Fragment 2 }\end{array}$ & $\begin{array}{c}\text { NTS around } \\
\text { Fragment 1 }\end{array}$ & $\begin{array}{c}\text { NTS around } \\
\text { Fragment 2 }\end{array}$ \\
\hline $\mathrm{pH}\left(\mathrm{CaCl} l_{2}\right.$ & 4.8 & 4.7 & 5.1 & 5.1 \\
$0.01 \mathrm{M})$ & 8.1 & 4.1 & 10.8 & 30.1 \\
$\mathrm{P}\left(\mathrm{mg} / \mathrm{dm}^{3}\right)$ & 0.5 & 0.6 & 0.4 & 0.5 \\
$\mathrm{~K}\left(\mathrm{cmol}_{\mathrm{c}} / \mathrm{dm}^{3}\right)$ & 1.4 & 1.2 & 2.9 & 3.0 \\
$\mathrm{Ca}\left(\mathrm{cmol}_{\mathrm{c}} / \mathrm{dm}^{3}\right)$ & 1.1 & 0.8 & 1.4 & 2.0 \\
$\mathrm{Mg}\left(\mathrm{cmol}_{\mathrm{c}} / \mathrm{dm}^{3}\right)$ & 0.1 & 0.1 & 0.1 & 0.1 \\
$\mathrm{Al}\left(\mathrm{cmol}_{\mathrm{c}} / \mathrm{dm}^{3}\right)$ & 5.0 & 2.2 & 3.2 & 3.5 \\
$\mathrm{H}+\mathrm{Al}^{3}$ & 3.0 & 2.6 & 4.7 & 5.5 \\
$\left(\mathrm{cmol} / \mathrm{dm}^{3}\right)$ & 8.0 & 4.8 & 7.9 & 9.0 \\
$\mathrm{SB}$ & 37.7 & 54.1 & 59.4 & 61.0 \\
$\mathrm{C.E.C}(\mathrm{pH} 7.0)$ & $\mathrm{V} \%$ & & &
\end{tabular}

Laboratory: NUTRISOLO, Ivinhema, MS. Chemical characterization - Calcium Chloride ( $\mathrm{pH}$ ); Mehlich $(\mathrm{P}$ and $\mathrm{K}) ; \mathrm{KCl} 1 \mathrm{~N}(\mathrm{Ca}, \mathrm{Mg}$ and $\mathrm{Al})$; Calcium Acetate $\mathrm{pH} 7.0(\mathrm{H}+\mathrm{Al})$. SB: Sum of bases, C.E.C: Cation exchange capacity, V\%: Base saturation.

Surrounding the two fragments, there are areas of agricultural cultivation under the notillage system (NTS) that total 76.1 ha. The fragments show no difference in management, where these remaining forest fragments were cleared in 1970 for the cultivation of mint for 10 years. From 1980, soybean/corn was cultivated in a conventional tillage system (CTS) until 2002, when the areas were converted to the NTS in the same succession system of CTS crops, which remains to date. However, in these two forest fragments, until 2000, there was forest management with removal of larger trees from the outermost areas, that is, until this year, anthropic actions existed within these fragments modifying their vegetation.

\subsection{Soil sample collections}

Soil collections were performed at four points, three points within the fragments and one point around them, in the NTS areas. The internal points correspond to the edge of the fragment (E), the central point between the edge and the center of the fragment, called half radius (HR), the center of the fragment $(\mathrm{CF})$, and the point external to the fragments in the NTS areas surrounding the fragments. The layout of the points is described in Table 3. 
Table 3. Description of the collection points in the fragments and their distance from the edge of the fragments.

\begin{tabular}{clcc}
\hline & & Fragments (distance (m) from the edge) \\
\hline & & \multicolumn{2}{c}{ Fragments } \\
\hline Collection point & Description of the point & $\mathbf{1}$ & $\mathbf{2}$ \\
\hline P. $\mathbf{1}$ & Center of the fragment (CF) & 310 & 310 \\
P. 2 & Half the radius of the fragment (HR) & 155 & 155 \\
P. 3 & Edge of the fragment (E) & 0 & 0 \\
P. 4 & Outside of the fragment (NTS) & 310 & 310 \\
\hline
\end{tabular}

For each collection point, 4 replicates were performed in a radius of $20 \mathrm{~m}^{2}$. Samples of disturbed and undisturbed soils were collected in the interior, and in the NTS areas around the fragments. The undisturbed samples to evaluate soil density (Ds) were collected with the aid of a volumetric ring with volume of $48.86 \mathrm{~cm}^{3}$. The disturbed samples were acquired with the aid of auger, by collecting three simple samples, in the layers of 0-0.05, 0.05-0.1 and 0.1-0.2 m. Some disturbed samples of the 0-0.05 m layer were immediately refrigerated for analysis of C$\mathrm{CO}_{2}$ (mineralizable carbon) evolution.

\subsection{Analyses Performed}

After collection, the disturbed samples were air-dried, disaggregated and passed through a $2 \mathrm{~mm}$ sieve to obtain thin air-dried soil (TADS). The total organic carbon (TOC) was determined by the oxidation of organic matter by potassium dichromate, in a sulfuric medium under heating, and titrated with ammoniacal ferrous sulfate (Yeomans and Bremner, 1988).

The physical granulometric fractionation of the SOM was performed following the methodology of Cambardella and Elliott (1992), in which $20 \mathrm{~g}$ of TADS, together with $60 \mathrm{ml}$ of sodium hexametaphosphate $\left(5 \mathrm{~g} \mathrm{~L}^{-1}\right)$ were placed in $250 \mathrm{ml}$ Erlenmeyer, stirred for 16 hours on an agitating table at a speed of $150 \mathrm{rpm}$. After the stirring period, the samples were washed in a $53 \mu \mathrm{m}$ sieve, and the material retained in the sieve consisted of particulate organic matter (POM), obtaining later, by the methodology of Yeomans and Bremner (1988), the carbon of particulate organic matter (C-POM) and, through the difference between TOC and C-POM, the carbon of mineral organic matter (C-MOM) was obtained.

After carbon determinations of the physical granulometric fractions of the SOM, indices were calculated to evaluate the quality of the SOM, which were; carbon stock index (CSI) (Equation 1), SOM lability (L) (Equation 2), lability index (LI) (Equation 3) and carbon management index (CMI) (Equation 4), calculated according to Blair et al. (1995).

$$
\begin{aligned}
& \text { CSI }=\frac{\text { TOC Treatment }}{\text { TOC Reference }} \\
& \mathrm{L}=\frac{\text { C-POM }}{\text { C-MOM }} \\
& \mathrm{LI}=\frac{\mathrm{L} \text { Treatment }}{\text { L Reference }} \\
& \text { CMI }=\text { CSI } \times \text { LI } \times 100
\end{aligned}
$$

Where:

CSI = Carbon stock index;

TOC Treatment $=$ Stock TOC $\left(\mathrm{Mg} \mathrm{ha}^{-1}\right)$ in the evaluated management system;

TOC Reference $=$ Stock TOC $\left(\mathrm{Mg} \mathrm{ha}^{-1}\right)$ in the reference system; $\mathrm{L}=$ lability of SOM;

C-POM = Carbon of particulate organic matter; 
C-MOM = Carbon of mineral organic matter;

$\mathbf{L I}=$ Lability index of the management system under analysis;

L Treatment $=$ Lability of SOM in the management system under analysis;

L Reference $=$ Lability of SOM in the reference system;

$\mathbf{C M I}=$ Carbon management index .

For the calculations of carbon stock of particulate organic matter (StockC-POM) and carbon stock of mineral organic matter (StockC-MOM), the soil density of the undisturbed samples was determined according to Claessen (1997), and the stocks were calculated according to the equivalent mass method (Equation 5) (Reis et al., 2018; Signor et al., 2014).

Equivalent mass method $=(\mathrm{Sd}$ of the evaluated treatment $\mathrm{x}$ Corrected thickness $\mathrm{x}$ Content $(\mathrm{C}-$ POM, C - MOM)) / Rated thickness

Where:

Sd of the evaluated treatment $=$ Soil density of the evaluated treatment;

Corrected thickness $=$ Corrected soil thickness (Average treatment density / average reference density $\mathrm{x}$ evaluated thickness);

Content $($ C-POM, C-MOM $)=$ Carbon content of particulate organic matter to result in MOP stock, and mineral organic matter to result in MOM stock, of the evaluated treatments;

Rated thickness $=$ Soil thickness sampled.

The analysis of the mineralizable carbon emission $\left(\mathrm{C}-\mathrm{CO}_{2}\right)$, was carried out following the methodology of Mendonça and Matos (2005). Thus, $50 \mathrm{~g}$ of soil were placed inside a plastic container of $3 \mathrm{~L}$ capacity, together with a glass container with $30 \mathrm{ml}$ of $0.5 \mathrm{~mol} \mathrm{~L}^{-1} \mathrm{NaOH}$ solution to capture the C-CO $\mathrm{CO}_{2}$ emitted, and a flask with $30 \mathrm{ml}$ of $\mathrm{H}_{2} \mathrm{O}$ in order to maintain constant moisture. The plastic container was hermetically sealed. Each day of evaluation, 10 $\mathrm{ml}$ of $\mathrm{NaCl}_{2}$ were removed from the glass container, and $10 \mathrm{ml}$ of $\mathrm{BaCl}_{2} 0.05 \mathrm{~mol} \mathrm{~L}^{-1}$ and 4 drops of phenolphthalein $1 \%$ were added, with subsequent titration with $\mathrm{HCl} 0.25 \mathrm{~mol} \mathrm{~L}^{-1}$. After removing the $30 \mathrm{~mL}$ container of $0.5 \mathrm{~mol} \mathrm{~L}^{-1} \mathrm{NaOH}$ solution, a new container with $30 \mathrm{~mL}$ was inserted for the next evaluation, leaving the plastic container open for 15 minutes to change the air before the next incubation. The titrations/evaluations were performed at 24-hour intervals in the first 7 days, $48 \mathrm{~h}$ between the 8th and 17th day, and $96 \mathrm{~h}$ between the 18th and 33rd day, as performed by Loss et al. (2013) and Rosset et al. (2019b).

The results obtained met the assumptions of normality and homogeneity of variance by means of the Shapiro-Wilk test and Bartlett's test. Subsequently, in a completely randomized design, the results were submitted to variance analysis with application of the F test, in isolation, evaluating each fragment individually, and the mean values compared by the Tukey test at 5\% with the aid of the R Core Team program (2019).

\section{RESULTS AND DISCUSSION}

The forest fragments of the Atlantic Forest biome presented the highest levels of TOC in the CF points, differing from the other points within and around the fragments, reaching $63.2 \mathrm{~g}$ $\mathrm{kg}^{-1}$ and $60.9 \mathrm{~g} \mathrm{~kg}^{-1}$ in Fragments 1 and 2, respectively, in the $0-0.05 \mathrm{~m}$ layer in the CF points (Figure 2). In general, the lowest levels of TOC were observed in the areas of NTS around the fragments, with lower levels in the 0.10-0.20 m layer (Figure 2).

The E and HR points showed a decrease in TOC levels in the 0-0.05 m layer when compared to the $\mathrm{CF}$ point, with relative reductions of $46.1 \%$ and $28.9 \%$ for Point $\mathrm{E}$, and $47.2 \%$ 
and $34.4 \%$ for Point HR, of Fragments 1 and 2, respectively. The NTS areas showed the greatest reductions in TOC levels when compared to the CF point, with 53.1 and $47.4 \%$ reduction, in the 0-0.05 m layer of Fragments 1 and 2, respectively (Figure 2).

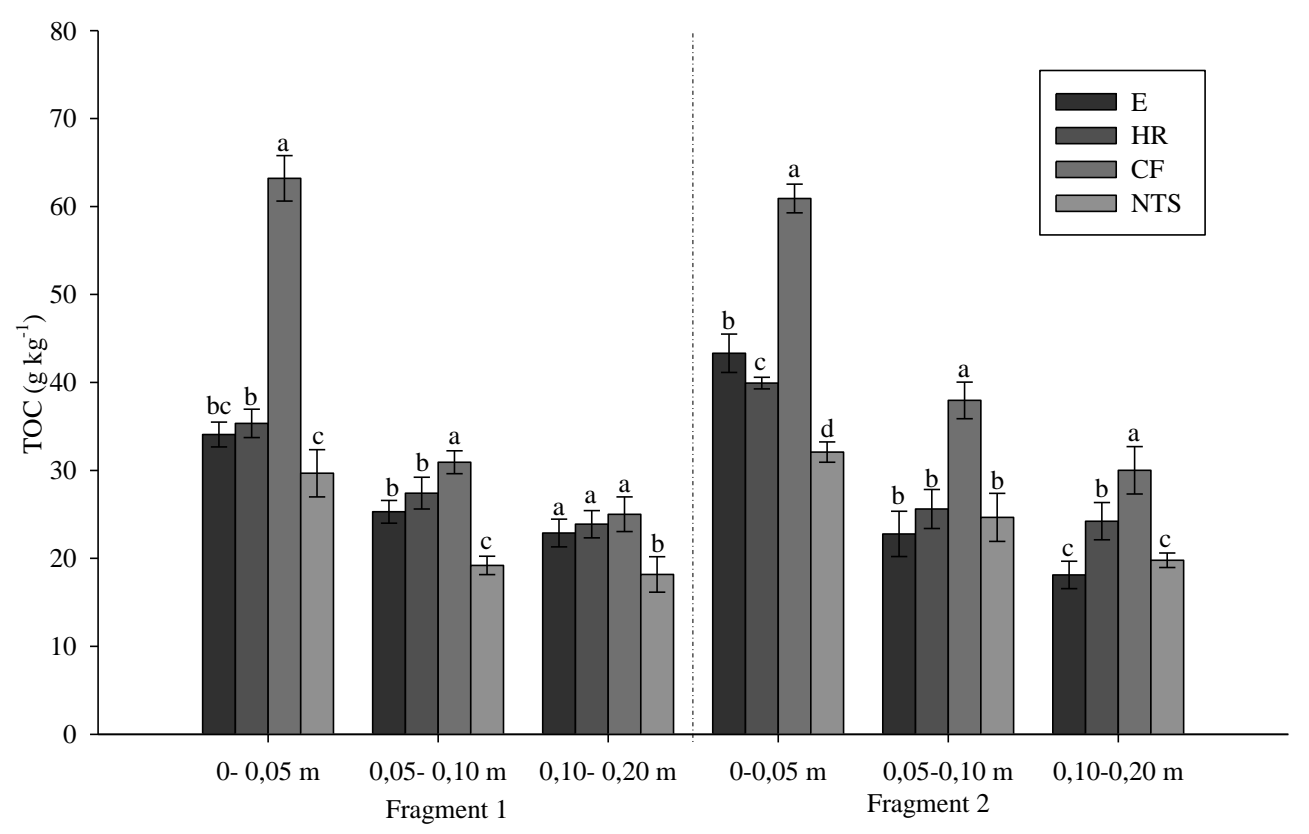

Figure 2. Total organic carbon (TOC) from the different collection points within and around fragments 1 and 2. Means followed by the same letter in the layer, for each fragment, do not differ statistically by the Tukey test (5\%). E: Fragment edge; HR: Half radius; CF: Center of the fragment; NTS: No-tillage system. Dashes on the bars represent the standard deviation of the data.

The higher levels of TOC in the CF point compared to E and HR is mainly due to the greater isolation of this point in relation to the external factors, indicating that the points near the edge suffer greater influence of fragmentation, mainly due to the higher incidence of light and microclimatic changes in these areas (Laurance et al., 1998). The highest contents presented by the internal points of the fragments compared to the NTS area is due to the greater contribution of litter in the most different forms (leaves, branches, fruits and thin roots), that is, a greater heterogeneity in the carbon/nitrogen ratio (C/N) (Matos et al., 2017), which maintains the flow of TOC and increases carbon stocks in these areas (Rosset et al., 2014; Freitas et al., 2018; Assunção et al., 2019).

On the other hand, the conversion of native areas into NTS ends up reducing the soil TOC, which, with the revolving, exposes the SOM to the oxidation process, increasing the emission of carbon dioxide $\left(\mathrm{CO}_{2}\right)$ into the atmosphere (Reinsch et al., 2018). These results corroborate those presented by Rosset et al. (2014; 2016; 2019b), Assunção et al. (2019) and Pereira and Neves (2007), who obtained higher levels of TOC in native forest areas, compared to areas of NTS with up to 22 years of conduction, in the same area, with the same type of soil and vegetation.

The highest levels of C-POM in the 0-0.05 m layer were found in E and CF points in Fragment 1, 13.2 and $12.1 \mathrm{~g} \mathrm{~kg}^{-1}$, respectively, and CF in Fragment 2, $19.5 \mathrm{~g} \mathrm{~kg}^{-1}$, differing from the other points (Table 4). The Points E, HR and CF do not undergo anthropic alterations, therefore presenting a higher conservation status, with constant deposition of organic material on the soil surface (Malchow et al., 2017), in addition to presenting greater diversity of plant species, different decomposition times and C/N ratio (Nascimento and Laurance, 2006), which favors the diversity of SOM, and consequent accumulation of particulate matter. 
Table 4. Carbon of particulate organic matter (C-POM) and mineral (C-MOM), percentage of carbon of particulate organic matter (POM) and mineral (MOM), carbon stock of particulate organic matter (StockPOM) and mineral (StockMOM) at different collection points within and around Fragments 1 and 2 of the Atlantic Forest biome.

\begin{tabular}{|c|c|c|c|c|c|c|c|c|c|c|c|c|}
\hline \multicolumn{7}{|c|}{ Fragment 1} & \multicolumn{6}{|c|}{ Fragment 2} \\
\hline & C-POM & C-MOM & POM & MOM & StockPOM & StockMOM & C-POM & C-MOM & POM & MOM & StockPOM & StockMOM \\
\hline & \multicolumn{2}{|c|}{$\mathrm{g} \mathrm{kg}^{-1}$} & \multicolumn{2}{|c|}{$\%$} & \multicolumn{2}{|c|}{$\mathrm{Mg} \mathrm{ha}^{-1}$} & \multicolumn{2}{|c|}{$\mathrm{g} \mathrm{kg}^{-1}$} & \multicolumn{2}{|c|}{$\%$} & \multicolumn{2}{|c|}{$\mathrm{Mg} \mathrm{ha}^{-1}$} \\
\hline \multicolumn{13}{|c|}{$0-0.05 \mathrm{~m}$} \\
\hline $\mathrm{E}$ & $13.2 \mathrm{a}$ & $20.8 \mathrm{c}$ & $38.9 a$ & $61.1 c$ & $4.7 \mathrm{a}$ & $7.4 \mathrm{c}$ & $15.3 b$ & $28.0 \mathrm{~b}$ & $35.7 \mathrm{a}$ & $64.5 b$ & $5.5 b$ & $10.0 \mathrm{~b}$ \\
\hline $\mathrm{HR}$ & $8.5 b$ & $26.9 b$ & $24.2 b c$ & 75.8ab & $3.0 \mathrm{~b}$ & $9.5 b$ & $11.6 \mathrm{c}$ & $28.4 \mathrm{~b}$ & $29.0 \mathrm{~b}$ & $71.0 \mathrm{a}$ & $4.1 c$ & $10.1 b$ \\
\hline $\mathrm{CF}$ & $12.1 \mathrm{a}$ & $51.1 \mathrm{a}$ & $19.1 c$ & $80.9 a$ & $4.3 \mathrm{a}$ & $18.4 \mathrm{a}$ & $19.5 \mathrm{a}$ & $41.4 \mathrm{a}$ & $32.1 \mathrm{ab}$ & 67.9ab & $7.0 \mathrm{a}$ & $14.8 \mathrm{a}$ \\
\hline NTS & $8.2 b$ & $21.4 \mathrm{bc}$ & $28.0 b$ & $72.0 \mathrm{~b}$ & $2.9 \mathrm{~b}$ & $7.6 \mathrm{bc}$ & $10.9 \mathrm{c}$ & $21.2 \mathrm{c}$ & $33.9 \mathrm{a}$ & $66.0 \mathrm{~b}$ & $3.9 \mathrm{c}$ & $7.5 \mathrm{c}$ \\
\hline $\mathrm{CV}(\%)$ & 10.1 & 9.0 & 14.7 & 5.6 & 10.1 & 9.0 & 6.8 & 6.3 & 8.7 & 8.7 & 6.8 & 6.3 \\
\hline \multicolumn{13}{|c|}{$0.05-0.10 \mathrm{~m}$} \\
\hline $\mathrm{E}$ & $5.6 b$ & $19.6 b$ & $22.4 b$ & $77.6 \mathrm{a}$ & $2.4 \mathrm{~b}$ & $8.3 b$ & $10.1 \mathrm{ab}$ & $12.7 \mathrm{c}$ & $44.4 \mathrm{a}$ & $55.6 \mathrm{~b}$ & $4.1 \mathrm{ab}$ & $5.2 \mathrm{c}$ \\
\hline HR & $5.1 \mathrm{~b}$ & $22.3 \mathrm{ab}$ & $18.5 b$ & $81.4 \mathrm{a}$ & $2.1 \mathrm{~b}$ & $9.4 \mathrm{ab}$ & $8.1 b c$ & $17.5 b$ & $31.7 b$ & $68.2 \mathrm{a}$ & $3.3 \mathrm{bc}$ & $7.1 \mathrm{~b}$ \\
\hline $\mathrm{CF}$ & $7.0 \mathrm{a}$ & $24.0 \mathrm{a}$ & $22.4 b$ & $77.5 \mathrm{a}$ & $2.9 \mathrm{a}$ & $10.1 \mathrm{a}$ & $10.7 \mathrm{a}$ & $27.2 \mathrm{a}$ & $28.1 b$ & $70.9 a$ & $4.4 \mathrm{a}$ & $11.2 \mathrm{a}$ \\
\hline NTS & $5.3 b$ & $13.9 \mathrm{c}$ & $27.7 \mathrm{a}$ & $72.3 b$ & $2.2 \mathrm{~b}$ & $5.9 \mathrm{c}$ & $7.5 c$ & $17.1 \mathrm{~b}$ & $30.7 b$ & $69.3 \mathrm{a}$ & $3.1 \mathrm{c}$ & $7.0 \mathrm{~b}$ \\
\hline $\mathrm{CV}(\%)$ & 10.3 & 7.1 & 10.6 & 3.1 & 10.3 & 7.1 & 12.5 & 9.5 & 9.2 & 4.7 & 12.5 & 9.5 \\
\hline \multicolumn{13}{|c|}{$0.10-0.20 \mathrm{~m}$} \\
\hline $\mathrm{E}$ & $3.0 \mathrm{~b}$ & $19.8 \mathrm{a}$ & $13.3 \mathrm{a}$ & $86.7 \mathrm{a}$ & $2.6 \mathrm{~b}$ & $17.0 \mathrm{a}$ & $6.3 \mathrm{ab}$ & $11.8 \mathrm{c}$ & $34.9 \mathrm{a}$ & $65.1 b$ & $5.1 \mathrm{ab}$ & $9.7 \mathrm{c}$ \\
\hline $\mathrm{HR}$ & $3.6 \mathrm{a}$ & $20.3 a$ & $15.0 \mathrm{a}$ & $85.1 \mathrm{a}$ & $3.1 \mathrm{ab}$ & $17.4 \mathrm{a}$ & $5.5 \mathrm{ab}$ & $18.7 \mathrm{~b}$ & $22.8 b$ & $77.2 \mathrm{a}$ & $4.5 \mathrm{ab}$ & $15.3 b$ \\
\hline $\mathrm{CF}$ & $3.9 \mathrm{a}$ & $21.1 \mathrm{a}$ & $15.7 \mathrm{a}$ & $84.3 a$ & $3.7 \mathrm{a}$ & $18.1 \mathrm{a}$ & $6.4 \mathrm{a}$ & $23.6 \mathrm{a}$ & $21.6 b$ & $78.4 \mathrm{a}$ & $5.2 \mathrm{a}$ & $19.3 \mathrm{a}$ \\
\hline NTS & $3.1 \mathrm{ab}$ & $15.1 b$ & $17.4 \mathrm{a}$ & $82.6 \mathrm{a}$ & $2.7 \mathrm{ab}$ & $12.9 b$ & $4.6 b$ & $15.2 \mathrm{bc}$ & $22.9 b$ & $77.0 \mathrm{a}$ & $3.7 b$ & $12.4 \mathrm{bc}$ \\
\hline $\mathrm{CV}(\%)$ & 12.1 & 9.6 & 17.4 & 3.1 & 12.0 & 9.6 & 15.1 & 12.2 & 17.8 & 6.1 & 15.1 & 12.2 \\
\hline
\end{tabular}

Means followed by the same letter in the columns for each fragment and layer do not differ statistically by the Tukey test (5\%). E: Fragment edge; HR: Half radius; CF: Center of the fragment; NTS: No-tillage system; CV (\%): coefficient of variation. 
In the 0.10-0.20 m layer of fragment 1, the lowest C-POM contents were found in Point E, $3.0 \mathrm{~g} \mathrm{~kg}^{-1}$, and in the surrounding NTS area, with $3.1 \mathrm{~g} \mathrm{~kg}^{-1}$. In Fragment 2, the lowest level of C-POM was found in the NTS area, $4.6 \mathrm{~g} \mathrm{~kg}^{-1}$ (Table 4). These results suggest that the low plant heterogeneity of the NTS, since it does not have a diversified rotation (Boddey et al., 2010), may compromise the dynamics of particulate matter entry into the soil over the years of cultivation (Ferreira et al., 2018).

The highest C-MOM contents were found in the CF point in the 0-0.05 m layer in both fragments, reaching 51.1 and $41.4 \mathrm{~g} \mathrm{~kg}^{-1}$ in Fragments 1 and 2, respectively. In Fragment 2, the CF point presented higher contents in all evaluated layers (Table 4). In the layer $0.10-0.20 \mathrm{~m}$ in Fragment 1, E, HR and CF points presented the highest C-MOM contents, differing from the NTS area. These results are due to the higher levels of TOC in the CF point (Figure 2). In addition, not revolving the soil allows humification processes to occur completely, promoting the stabilization of SOM (Lal, 2018), and consequent carbon accumulation in the most recalcitrant fractions.

The lowest levels of C-MOM were observed in the 0.10-0.20 m layer, in the NTS area around Fragment 1, and in point E and NTS area of Fragment 2 (Table 4). The fact that only soybean/corn succession has been cultivated for several years in the areas of NTS, also influences on the lower carbon content of this fraction, because the greater diversity of plant residues left in systems with greater crop diversity considerably increases the entry of SOM in the most labile fraction of carbon and, consequently, over time, of the more recalcitrant fractions of C (Faccin et al., 2017), when compared to systems with less diversity (Boddey et al., 2010; Campos et al., 2011).

The percentage of POM and MOM, which shows the representativeness of these fractions in relation to TOC, varied from 13.3 to $38.9 \%$ for POM, and from 61.1 to $86.7 \%$ for MOM in all points and layers evaluated in Fragment 1. In Fragment 2, this variation was from $21.6 \%$ to 44.4, and from 55.6\% to $78.4 \%$, respectively, for POM and MOM (Table 4). The high representativeness of MOM is associated with soil granulometry of the studied areas, since the most stable soil organic matter binds to the colloidal fraction (Cambardella and Elliott, 1992), which represents most of the soil granulometry of the study areas. In addition, the tropical climate plays a fundamental role in this behavior of distribution of the granulometric fractions of the POM, because it acts directly in the humification process of the SOM, converting the POM into MOM in a faster process than in temperate climate regions (Gmach et al., 2018), providing greater representativeness of MOM in relation to POM. This fact was also highlighted by Rosset et al. (2019b) in the same area of this study, also in native areas and managed under NTS.

It is important to highlight that the percentage representativeness of the fractions had a similar pattern in both fragments studied (Table 4), where the percentage of POM decreased, and of MOM increased as a function of the increase in depth. This occurs mainly due to the greater contribution of particulate matter to the soil surface, which associated with nonrevolving, transforms this labile material into recalcitrant along the profile (Lal, 2018; Reinsch et al., 2018).

The highest StockPOM and StockMOM were observed in the CF points of both fragments (Table 4), corroborating the higher levels of TOC in this same point (Figure 2). Specifically, in Fragment 1, in the 0-0.05 m layer, the StockPOM was similar between the E and CF points, with values of 4.7 and $4.3 \mathrm{Mg} \mathrm{ha}^{-1}$, respectively. In Fragment 2, in Point CF, the StockPOM presented the highest value, $6.7 \mathrm{Mg} \mathrm{ha}^{-1}$, in the 0-0.05 m layer, differing from the other points.

In Fragment 1, the CF point presented StockMOM of $18.4 \mathrm{Mg} \mathrm{ha}^{-1}$, differing from the other points in the 0-0.05 m layer. In Fragment 2, the StockMOM was $14.7 \mathrm{Mg} \mathrm{ha}^{-1}, 11.2 \mathrm{Mg}$ $\mathrm{ha}^{-1}$ and 19.3 $\mathrm{Mg} \mathrm{ha}^{-1}$ in layers 0-0.05, 0.05-0.10 and 0.10-0.20 m, respectively, in the CF Point, higher than all other points studied (Table 4). Lower values of StockPOM and StockMOM in the areas of NTS around the two studied fragments are notorious, especially in the 0-0.05 m layer. 
The highest StockPOM and StockMOM, mainly in the CF Point (Table 4) are due to the highest levels of TOC (Figure 2), C-POM and C-MOM (Table 4). Because it is more isolated in relation to the other points, the CF Point presents greater diversity of forest strata and constant litter deposition (Malchow et al., 2017), which allows biogeochemical processes to be completed (Smith, 2012; Gmach et al. 2018), thus enabling to find high stocks of both fractions (Melo et al., 2016). In a study in a system with permanent pasture, regeneration and native forest in the Atlantic Forest biome, Nogueira et al. (2016) also found higher stocks of POM and MOM in the native forest area compared to different production systems, as similarly evidenced by Rosset et al. (2019b) in the same edaphoclimatic conditions and management systems.

The Points E, HR and areas NTS around both fragments presented lower CSI values in relation to the reference point $(\mathrm{CF})$. The lowest values were observed in the NTS areas in the layer $0-0.05$ m, 0.5 and 0.5 around Fragments 1 and 2, respectively (Table 5). These results indicate that none of the points evaluated, in both fragments, presented carbon storage higher than the inner point, as also reported for the TOC contents (Figure 2), because all values of this variable were lower than 1.0 (Table 5).

Table 5. Carbon stock index (CSI), SOM lability (L), lability index (LI) and carbon management index (CMI) of the different collection points, within and around Fragments 1 and 2.

\begin{tabular}{|c|c|c|c|c|c|c|c|c|}
\hline & \multicolumn{4}{|c|}{ Fragment 1} & \multicolumn{4}{|c|}{ Fragment 2} \\
\hline & CSI & $\mathrm{L}$ & LI & CMI & CSI & $\mathrm{L}$ & LI & CMI \\
\hline \multicolumn{9}{|c|}{$0-0.05 \mathrm{~m}$} \\
\hline $\mathrm{E}$ & $0.5 b$ & $0.6 \mathrm{a}$ & $2.7 \mathrm{a}$ & $147.9 \mathrm{a}$ & $0.7 b$ & $0.5 \mathrm{a}$ & $1.2 \mathrm{a}$ & $83.4 b$ \\
\hline HR & $0.5 b$ & $0.3 b$ & $1.3 b$ & $75.5 b$ & $0.6 \mathrm{~b}$ & $0.4 \mathrm{~b}$ & $0.9 b$ & $56.9 \mathrm{c}$ \\
\hline $\mathrm{CF}$ & $1.0 \mathrm{a}$ & $0.2 b$ & $1.0 \mathrm{~b}$ & $100.0 \mathrm{~b}$ & $1.0 \mathrm{a}$ & $0.5 \mathrm{ab}$ & $1.0 \mathrm{ab}$ & $100.0 \mathrm{a}$ \\
\hline NTS & $0.5 \mathrm{c}$ & $0.4 \mathrm{~b}$ & $1.6 \mathrm{~b}$ & $76.7 \mathrm{~b}$ & $0.5 \mathrm{c}$ & $0.5 \mathrm{ab}$ & $1.1 \mathrm{ab}$ & $57.3 \mathrm{c}$ \\
\hline $\mathrm{CV}(\%)$ & 3.8 & 21.8 & 21.6 & 19.1 & 4.4 & 10.8 & 11.4 & 20.0 \\
\hline \multicolumn{9}{|c|}{$0.05-0.10 \mathrm{~m}$} \\
\hline E & $0.8 \mathrm{~b}$ & $0.3 b$ & $1.0 \mathrm{ab}$ & $82.1 \mathrm{ab}$ & $0.6 \mathrm{~b}$ & $0.8 \mathrm{a}$ & $2.1 \mathrm{a}$ & $123.6 \mathrm{a}$ \\
\hline HR & $0.9 \mathrm{~b}$ & $0.2 b$ & $0.8 \mathrm{~b}$ & $69.3 b$ & $0.7 b$ & $0.5 \mathrm{~b}$ & $1.2 \mathrm{~b}$ & $82.3 b$ \\
\hline $\mathrm{CF}$ & $1.0 \mathrm{a}$ & $0.3 b$ & $1.0 \mathrm{~b}$ & $100.0 \mathrm{a}$ & $1.0 \mathrm{a}$ & $0.4 \mathrm{~b}$ & $1.0 \mathrm{~b}$ & $100.0 \mathrm{ab}$ \\
\hline NTS & $0.6 \mathrm{c}$ & $0.4 \mathrm{a}$ & $1.3 \mathrm{a}$ & $82.5 \mathrm{ab}$ & $0.6 b$ & $0.4 b$ & $1.1 \mathrm{~b}$ & $75.4 b$ \\
\hline CV (\%) & 5.8 & 13.6 & 15.8 & 11.6 & 7.6 & 13.7 & 21.2 & 18.4 \\
\hline \multicolumn{9}{|c|}{$0.10-0.20 \mathrm{~m}$} \\
\hline $\mathrm{E}$ & $0.9 \mathrm{a}$ & $0.1 \mathrm{a}$ & $0.8 \mathrm{a}$ & $76.1 \mathrm{a}$ & $0.6 \mathrm{c}$ & $0.5 \mathrm{a}$ & $2.0 \mathrm{a}$ & $122.9 \mathrm{a}$ \\
\hline HR & $0.9 \mathrm{a}$ & $0.2 \mathrm{a}$ & $0.9 \mathrm{a}$ & $90.5 \mathrm{a}$ & $0.8 \mathrm{~b}$ & $0.3 b$ & $1.1 \mathrm{~b}$ & $89.1 \mathrm{ab}$ \\
\hline $\mathrm{CF}$ & $1.0 \mathrm{a}$ & $0.2 \mathrm{a}$ & $1.0 \mathrm{a}$ & $100.0 \mathrm{a}$ & $1.0 \mathrm{a}$ & $0.3 b$ & $1.0 \mathrm{~b}$ & $100.0 \mathrm{ab}$ \\
\hline NTS & $0.7 \mathrm{~b}$ & $0.2 \mathrm{a}$ & $1.2 \mathrm{a}$ & $83.2 \mathrm{a}$ & $0.7 b c$ & $0.3 b$ & $1.1 \mathrm{~b}$ & $71.9 \mathrm{~b}$ \\
\hline $\mathrm{CV}(\%)$ & 9.5 & 21.7 & 27.4 & 16.5 & 11.5 & 25.5 & 31.8 & 22.5 \\
\hline
\end{tabular}

Means followed by the same letter in the columns for each fragment and layer do not differ statistically by the Tukey test (5\%). E: Fragment edge; HR: Half radius; CF: center of the fragment; NTS: No-tillage system; CV $(\%)$ : coefficient of variation.

These changes in carbon stock in E and HR points and in the NTS area compared to the reference suggest that the conversion of natural areas into production systems can reduce soil carbon storage (Rosset et al., 2014; Reis et al., 2016). In addition, forest fragmentation reduced 
the carbon stock in the points near the edge, possibly due to the changes it causes, with decreased TOC (Figure 2), by increasing luminosity and temperature (Camargo and Kapos, 1995), higher incidence of winds (Laurance et al., 1998), which can accelerate the oxidation process of SOM, releasing greater amounts of carbon dioxide into the atmosphere (Lal, 2018; Sperow, 2018; Magalhães et al., 2016). These results from the points near the edge contrast to those presented by Barros and Fearnside (2016), who found an increase in carbon stock on the edges of forest fragments in the Amazon.

The $\mathrm{L}$ values were below the unit in all points and layers evaluated, which indicates a predominance of $\mathrm{C}-\mathrm{MOM}$ in relation to the $\mathrm{C}-\mathrm{POM}$ (Table 5). The E point presented the highest $\mathrm{L}$ value (0.6), in the layer $0-0.05 \mathrm{~m}$, in fragment 1 , and in the layer $0.10-0.20 \mathrm{~m}$ there was no difference between the points, varying from 0.1 to 0.2 (Table 5). In Fragment 2, Point E presented the highest $\mathrm{L}$ values in all evaluated layers, $0.5 ; 0.8$ and 0.5 , for layers $0-0.05,0.05$ 0.10 and $0.10-0.20 \mathrm{~m}$. These results generally indicate low $\mathrm{L}$ of the $\mathrm{C}$ in these areas, because $\mathrm{L}$ represents the relationship between C-POM and C-MOM, which makes this variable an important indicator of soil quality, given the importance of balance between these fractions, for maintenance of $\mathrm{C}$ in the soil over time (Benbi et al., 2015; Jha, 2017).

The LI showed the same pattern of L values, indicating higher values in Point $\mathrm{E}$ of both fragments evaluated in the 0-0.05 m layer, surpassing the LI of the reference (CF). The CMI, which expresses the evaluation of SOM in quantitative and qualitative terms, presented higher values than the reference point (CF) only in Point $\mathrm{E}$ (147.9) in the layer 0-0.05 $\mathrm{m}$ in Fragment 1 , and the points evaluated did not present differences in the layer 0.10-0.20 $\mathrm{m}$ (Table 5). In Fragment 2, Point E presented values similar to those of CF in the 0.05-0.10 $\mathrm{m}$ and $0.10-0.20$ $\mathrm{m}$ layers (Table 5). This increase in CMI in Point $\mathrm{E}$ may be related to the greater litter intake that forest fragments present in the extremities (Malchow et al., 2017; Nascimento and Laurance, 2006; Barros and Fearnside, 2016), and also due to the higher values of L and consequently LI (Table 5).

In both fragments studied, CMI values lower than the reference area were observed in the surrounding NTS areas (Table 5). These results demonstrate that the modification caused by the conversion of natural areas may compromise soil quality (Rosset et al., 2019b), mainly in surface layers, affecting the quality of SOM due to the low diversity of species in the soybean/corn succession over the years of cultivation, which directly influences the physical quality (Sales et al., 2018), chemistry (Souza et al., 2018) and the biological activity (Borges et al., 2016) of the soil over the years of cultivation.

Forms of soil management that provide greater floristic heterogeneity and, consequently, higher CMI values, will act directly on the mentioned attributes, improving water infiltration (Souza et al., 2017) soil aggregation (Obour et al., 2018), porosity (Lal, 2018), among other quality indicators. Gazolla et al. (2015) obtained in their study a CMI value of 48.1 for layer 0$0.05 \mathrm{~m}$ in NTS with 10 years of implantation, compared to an area of native vegetation. Souza et al. (2018) studying NTS chronosequence in clay soil, obtained CMI of 112, 128 and 139 for NTS with 7, 11 and 16 years of implantation.

In Fragments 1 and 2, the $\mathrm{CF}$ point showed the highest $\mathrm{C}-\mathrm{CO}_{2}$ emission on the 1 st day after incubation, 14.1 and $12.1 \mathrm{mg}$ of $\mathrm{C}-\mathrm{CO}_{2}$ in $50 \mathrm{~g}$ of soil, respectively. The NTS areas presented the lowest emissions in the first evaluation, 5.5 and $5.9 \mathrm{mg}$ of $\mathrm{C}-\mathrm{CO}_{2}$ in $50 \mathrm{~g}$ of soil, respectively (Figures $3 \mathrm{a}, \mathrm{b}$ ). The points with the highest emissions on the 1st day were also the ones that presented the highest levels of TOC (Figure 2) and C-POM (Table 4) in the 0-0.05 m layer. This higher initial emission of $\mathrm{C}-\mathrm{CO}_{2}$ occurs when microbial activity is stimulated by the availability of labile organic residues, in this case C-POM, which accelerates the decomposition of SOM (Hurisso et al., 2016; 2018; Wade et al., 2018), having a relationship between higher levels of TOC (Figure 2) and C-POM (Table 4) with the highest C-CO $\mathrm{CO}_{2}$ emissions (Figures 2 a, b). 
In Fragments 1 and 2, between the 4th and 6th day, and between the 13th and 21st day of incubation, $\mathrm{C}-\mathrm{CO}_{2}$ emission peaks were evident (Figures $3 \mathrm{a}, \mathrm{b}$ ). These emission peaks occur due to the death of part of the microorganisms that serve as food for the remnants, generating emission peaks after the decreases (Gonçalves et al., 2002), an effect known as prining (Ghosh et al., 2018; Kuzyakov et al., 2000). In both fragments, from the 25th day on, the emission began to stabilize (Figures $3 \mathrm{a}, \mathrm{b}$ ), i.e., no $\mathrm{C}-\mathrm{CO}_{2}$ emission peaks were observed. This stabilization in $\mathrm{C}-\mathrm{CO}_{2}$ emission occurs by reducing the availability of labile organic materials readily available to microbial attack. This pattern was also observed by Loss et al. (2013) in Goiás and Rosset et al. (2019b) in Paraná, studying the emission of mineralizable carbon in Latosol in different management systems.
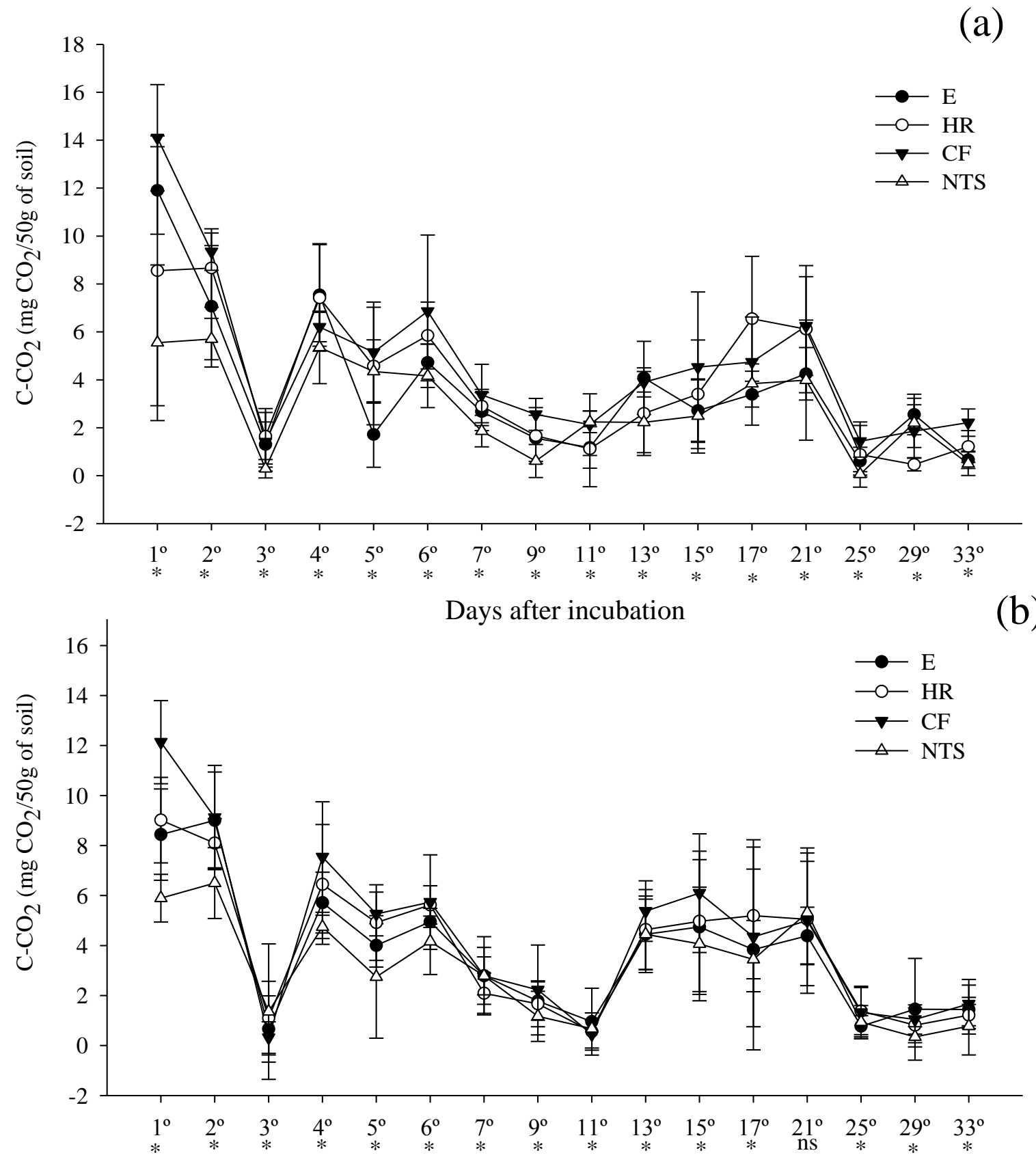

(b)

Days after incubation

Figure 3. Mineralizable carbon of the soil incubated in the laboratory until the 33rd day of the different collection points within and around Fragments 1 (a) and 2 (b). * = Significant by Tukey test at $5 \%$; ns $=$ Not significant by Tukey test at $5 \%$. 
The highest accumulations of $\mathrm{C}-\mathrm{CO}_{2}$ after the 33rd day of incubation were observed in the $\mathrm{CF}, 75.7$ and $69.7 \mathrm{mg} \mathrm{CO}$ in $50 \mathrm{~g}$ of soil in Fragments 1 and 2, respectively (Figure 4). The results also show that both fragments present a pattern of gradual total emission reduction when moving from the CF Point to the E, i.e., lower soil microbial activity is observed. The highest accumulations of total $\mathrm{C}-\mathrm{CO}_{2}$ occurred exactly in the points where the highest levels of TOC (Figure 2) and the highest levels of C-POM (Table 4) were obtained, ratifying the pattern also presented by Wade et al. (2018) and Rosset et al. (2019b).

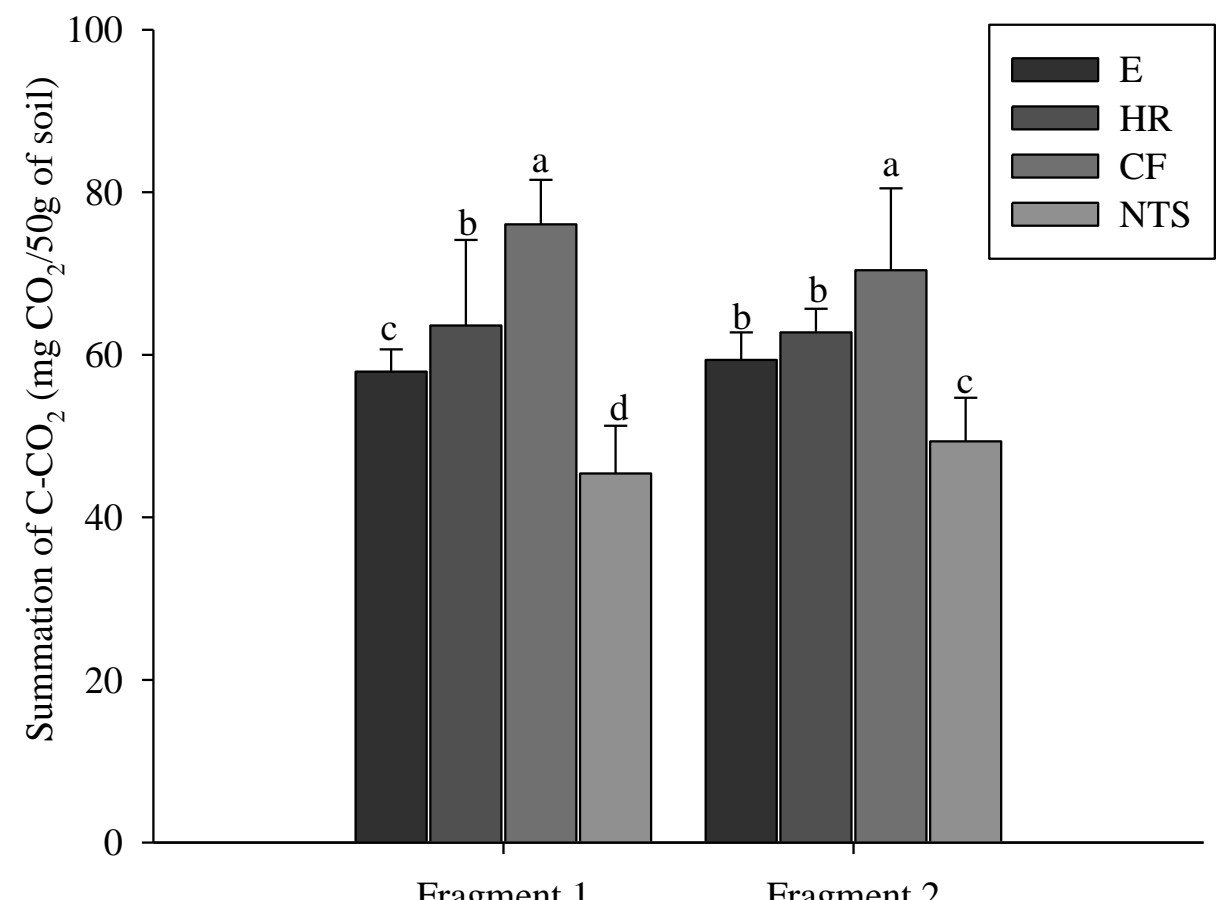

Fragment 1

Fragment 2

Figure 4. Summation of $\mathrm{C}-\mathrm{CO}_{2}(\mathrm{mg} \mathrm{CO} / 50 \mathrm{~g}$ of soil), during the incubation period of the soil in the laboratory, in the different collection points within and around Fragments 1 and 2. Means with the same letter do not differ statistically by the Tukey test (5\%). E: Fragment edge; HR: Half radius; CF: Center of the fragment; NTS: No-tillage system. Dashes on the bars represent the standard deviation of the data.

The NTS areas around the fragments presented the lowest total values of $\mathrm{C}-\mathrm{CO}_{2}$ emission, 45.6 and $49.9 \mathrm{mg} \mathrm{CO}$ in $50 \mathrm{~g}$ of soil, which represents $39.8 \%$ and $28.3 \%$ reduction for the highest emission points, for Fragments 1 and 2, respectively (Figure 4). In turn, the lowest levels of TOC (Figure 2) and C-POM (Table 4) were also observed in the areas of NTS, indicating the direct relationship of the organic matter of easier decomposition with the highest accumulations of total $\mathrm{C}-\mathrm{CO}_{2}$, and consequent microbiological activity (Barreto et al., 2009). Loss et al. (2013) and Rosset et al. (2019b) observed lower values of $\mathrm{C}^{-\mathrm{CO}_{2}}$ accumulation in NTS, compared to the area of native vegetation. The results contrast with those presented by Benbi et al. (2015), in which the managed areas showed higher evolution of $\mathrm{C}-\mathrm{CO}_{2}$, in relation to areas under native vegetation, after 32 days of incubation.

\section{CONCLUSIONS}

The levels of total organic carbon and particulate fraction of soil organic matter from the internal points of the forest fragments were higher than those of the no-tillage system areas around them, indicating that the conversion of native areas into cultivation systems compromises quantitatively and qualitatively the organic fraction of the soil. 
The carbon management index showed a distinct pattern among the studied fragments, and was not sensitive to identify internal changes in forest fragments.

The mineralizable carbon analysis indicated that the conversion of native areas into notillage systems, causes less microbial activity, also evidencing an increase in microbial activity when entering the most peripheral areas to the more central areas of the forest fragment in the Atlantic Forest biome.

\section{ACKNOWLEDGMENTS}

We thank Coordenação de Aperfeiçoamento de Pessoal de Nível Superior (CAPES), for granting the master's scholarship to the first author. Universidade Estadual de Mato Grosso do Sul through the Programa de Pós-Graduação em Agronomia - Produção Vegetal. We also thank the rural owners who made their areas available for soil sample collections.

\section{REFERENCES}

ASSUNÇÃO, S. A.; PEREIRA, M. G.; ROSSET, J. S.; BERBARA, R. L. L.; GARCÍA, A. C. Carbon input and the structural quality of soil organic matter as a function of agricultural management in a tropical climate region of Brazil. Science of the Total Environment, v. 658, p. 901-911, 2019. https://doi.org/10.1016/j.scitotenv.2018.12.271

BARRETO, R. C.; MADARI, B. E.; MADDOCK, J. E.; MACHADO, P. L.; TORRES, E.; FRANCHINI, J.; COSTA, A. R. The impact of soil management on aggregation, carbon stabilization and carbon loss as $\mathrm{CO}_{2}$ in the surface layer of a Rhodic Ferralsol in Southern Brazil. Agriculture, Ecosystems \& Environment, v. 132, n. 3-4, p. 243-251, 2009. https://doi.org/10.1016/j.agee.2009.04.008

BARROS, H. S.; FEARNSIDE, P. M. Soil carbon stock changes due to edge effects in central Amazon forest fragments. Forest Ecology and Management, v. 379, p. 30-36, 2016. https://doi.org/10.1016/j.foreco.2016.08.002

BENBI, D. K.; BRAR, K.; TOOR, A. S.; SINGH, P. Total and labile pools of soil organic carbon in cultivated and undisturbed soils in northern India. Geoderma, v. 237, p. 149158, 2015. https://doi.org/10.1016/j.geoderma.2014.09.002

BHERING, S. B.; SANTOS, H. G.; MANZATTO, C. V. et al. Mapa de solos do Estado do Paraná. Rio de Janeiro: Embrapa, 2007, 73p.

BLAIR, G. J.; LEFROY, R. D. B.; LISLE, L. Soil carbon fractions based on their degree of oxidation, and the development of a carbon management index for agricultural systems. Australian Journal of Agricultural Research, v. 46, n. 7, p. 1459-1466, 1995. https://doi.org/10.1071/AR9951459

BODDEY, R. M.; JANTALIA, C. P.; CONCEICÃO, P. C.; ZANATTA, J. A.; BAYER, C.; MIELNICZUK, J.; DIECKOW, J.; SANTOS, H. P.; DENARDIN, J. E.; AITA, C.; GIACOMINI, S. J.; ALVES, B. J. R.; URQUIAGA S. Carbon accumulation at depth in Ferralsols under zero-till subtropical agriculture. Global Change Biology, v. 16, n. 2, p. 784-795, 2010. https://doi.org/10.1111/j.1365-2486.2009.02020

BORGES, C.; RIBEIRO, B. T.; WENDLING, B.; CABRAL, D. A. Agregação do solo, carbono orgânico e emissão de $\mathrm{CO}_{2}$ em áreas sob diferentes usos no Cerrado, região do Triângulo Mineiro. Revista Ambiente \& Água, v. 10, n. 3, p. 661-675, 2016. https://doi.org/10.4136/ambi-agua.1573 
CAMARGO, J. L. C.; KAPOS, V. Complex edge effects on soil moisture and microclimate in central Amazonian forest. Journal of Tropical Ecology, v. 11, n. 2, p. 205-221, 1995. https://doi.org/10.1017/S026646740000866X

CAMBARDELLA, C. A.; ELLIOTT, E. T. Particulate soil organic-matter changes across a grassland cultivation sequence. Soil Science Society of America Journal, v. 56, n. 3, p. 777-783, 1992. http://dx.doi.org/10.2136/sssaj1992.03615995005600030017x

CAMPOS, B. H. C. D.; AMADO, T. J. C.; BAYER, C.; NICOLOSO, R. D. S.; FIORIN, J. E. Carbon stock and its compartments in a subtropical oxisol under long-term tillage and crop rotation systems. Revista Brasileira de Ciência do Solo, v. 35, n. 3, p. 805-817, 2011. https://doi.org/10.1590/S0100-06832011000300016

CAMPOS, J. B.; SILVEIRA FILHO, L. Série Ecossistemas Paranaenses - Floresta Estacional Semidecidual. Curitiba: Governo do Estado do Paraná, 2010. 8p.

CAVIGLIONE, J. H.; KIIHL, L. R. B.; CARAMORI, P. H.; OLIVEIRA, D. Cartas climáticas do Paraná. Londrina: IAPAR, 2000. CD-ROM.

CLAESSEN, M. E. C. Manual de métodos de análise de solo. 2. ed. Rio de Janeiro: Embrapa, 1997. $212 \mathrm{p}$.

FACCIN, F. C.; MARCHETTI, M. E.; SERRA, A. P.; ENSINAS, S. C. Frações granulométricas da matéria orgânica do solo em consórcio de milho safrinha com capimmarandu sob fontes de nitrogênio. Pesquisa Agropecuária Brasileira, v. 51, n. 12, p. 2000-2009, 2017. https://doi.org/10.1590/s0100-204x2016001200011

FERREIRA, A. O.; SÁ, J. C. M; LAL, R.; TIVET, F.; BRIEDIS, C.; INAGAKI, T. M.; ROMANIW, J. Macroaggregation and soil organic carbon restoration in a highly weathered Brazilian Oxisol after two decades under no-till. Science of the Total $\begin{array}{llllll}\text { Environment, } & \text { v. } & 621, & \text { p. } & 1559-1567, & 2018 .\end{array}$ https://doi.org/10.1016/j.scitotenv.2017.10.072

FERREIRA, C. R.; SILVA NETO, E. C.; PEREIRA, M. G.; GUEDES, J. N.; ROSSET, J. S.; ANJOS, L. H. C. Dynamics of soil aggregation and organic carbon fractions over 23 years of no-till management. Soil \& Tillage Research, v. 198, p. 1-9, 2020. https://doi.org/10.1016/j.still.2019.104533

FREITAS, L.; OLIVEIRA, I. A.; CASAGRANDE, J. C.; SILVA, L. S.; CAMPOS, M. C. C. Estoque de carbono de Latossolos em sistemas de manejo natural e alterado. Ciência Florestal, v. 28, n. 1, p. 228-239, 2018. https://dx.doi.org/10.5902/1980509831575

GAZOLLA, P. R.; GUARESCHI, R. F.; PERIN, A., PEREIRA, M. G.; ROSSI, C. Q. Frações da matéria orgânica do solo sob pastagem, sistema plantio direto e integração lavourapecuária. Semina: Ciências Agrárias, v. 36, n. 2, p. 693-704, 2015. https://doi.org/10.5433/1679-0359

GHOSH, A.; BHATTACHARYYA, R.; MEENA, M. C.; DWIVEDI, B. S.; SINGH, G.; AGNIHOTRI, R.; SHARMA, C. Long-term fertilization effects on soil organic carbon sequestration in an Inceptisol. Soil \& Tillage Research, v. 77, p. 134-144, 2018. https://doi.org/10.1016/j.still.2017.12.006

GMACH, M. R.; DIAS, B. O.; SILVA, C. A.; NÓBREGA, J. C.; LUSTOSA-FILHO, J. F.; SIQUEIRA-NETO, M. Soil organic matter dynamics and land-use change on Oxisols in the Cerrado, Brazil. Geoderma Regional, v. 14, p. 1-8, 2018. https://doi.org/10.1016/j.geodrs.2018.e00178 
GONÇALVES, A. S.; MONTEIRO, M. T.; GUERRA, J. G. M. DE-POLLI, H. Biomassa microbiana em amostras de solos secadas ao ar e reumedecidas. Pesquisa Agropecuária Brasileira, v. 37, n. 5, p. 651-658, 2002. https://doi.org/10.1590/S0100204X2002000500010

HURISSO, T. T.; CULMAN, S. W.; HORWATH, W. R.; WADE, J.; CASS, D.; BENISTON, J. W.; LUCAS, S. T. Comparison of permanganate-oxidizable carbon and mineralizable carbon for assessment of organic matter stabilization and mineralization. Soil Science Society of America Journal, v. 80, n. 5, p. 1352-1364, 2016. https://doi.org/10.2136/sssaj2016.04.0106

HURISSO, T. T.; CULMAN, S. W.; ZONE, P.; SHARMA, S. Absolute values and precision of emerging soil health indicators as affected by soil sieve size. Communications in Soil Science and Plant Analysis, v. 49, n. 15, p. 1934-1942, 2018. https://doi.org/10.1080/00103624.2018.1492597

JHA, P.; VERMA, S.; LAL, R.; EIDSON, C.; DHERI, G. S. Natural 13C abundance and soil carbon dynamics under long-term residue retention in a no-till maize system. Soil Use and Management, v. 33, n. 1, p. 90-97, 2017. https://doi.org/10.1111/sum.12323

KAPOS, V. Effects of isolation on the water status of forest patches in the Brazilian Amazon. $\begin{array}{lllllllll}\text { Journal of Tropical Ecology, v. } & \text { 5, n. 2, p. } & \text { 173-185, }\end{array}$ https://doi.org/10.1017/S0266467400003448

KUZYAKOV, Y.; FRIEDEL, J. K.; STAHR, K. Review of mechanisms and quantification of priming effects. Soil Biology and Biochemistry, v. 32, n. 11-12, p. 1485-1498, 2000. https://doi.org/10.1016/S0038-0717(00)00084-5

LAL, R. Digging deeper: A holistic perspective of factors affecting soil organic carbon sequestration in agroecosystems. Global Change Biology, v. 24, p. 3285-3301, 2018. https://doi.org/10.1111/gcb.14054

LAURANCE, W. F.; FERREIRA, L. V.; RANKIN-DE-MERONA, J. M.; LAURANCE, S. G. Rain forest fragmentation and the dynamics of Amazonian tree communities. Ecology, v. 79 , n. 6, p. 2032-2040, 1998. https://doi.org/10.1890/00129658(1998)079[2032:RFFATD]2.0.CO;2 0

LAURANCE, W. F.; VASCONCELOS, H. L. Consequências ecológicas da fragmentação florestal na Amazônia. Oecologia Brasiliensis, v. 13, n. 3, p. 434-451, 2009. https://doi.org/10.4257/oeco.2009.1303.03

LOSS, A.; PEREIRA, M. G.; BEUTLER, S. J.; PERIN, A.; ANJOS, L. H. C. Carbono mineralizável, carbono orgânico e nitrogênio em macroagregados de Latossolo sob diferentes sistemas de uso do solo no Cerrado Goiano. Semina: Ciências Agrárias, v. 34, n. 5, p. 2153-2168, 2013. https://doi.org/10.5433/1679-0359

MAGALHÃES, S. S. A.; RAMOS, F. T.; WEBER, O. L. S. Carbon stocks of an Oxisol after thirty-eight years under different tillage systems. Revista Brasileira de Engenharia Agrícola e Ambiental, v. 20, n. 1, p. 85-91, 2016. https://doi.org/10.1590/18071929/agriambi.v20n1p85-91

MALCHOW, E.; KOEHLER, A. B.; NETTO, S. P. Efeito de borda em um trecho da floresta ombrófila mista, em fazenda Rio Grande, PR. Revista Acadêmica: Ciência Animal, v. 4, n. 2, p. 85-94, 2017. https://doi.org/10.7213/cienciaanimal.v4i2.9357 
MATOS, N. M.; RIBEIRO, F. P.; GATTO, A.; BUSSINGUER, A. P. Estoque de Serapilheira em Três Fisionomias no Cerrado do Distrito Federal. Floresta e Ambiente, v. 24, p. 1-9, 2017. http://dx.doi.org/10.1590/2179-8087.126215

MELO, G. B.; PEREIRA, M. G.; PERIN, A.; GUARESCHI, R. F.; SOARES, P. F. C. Estoques e frações da matéria orgânica do solo sob os sistemas plantio direto e convencional de repolho. Pesquisa Agropecuária Brasileira, v. 51, n. 9, p. 1511-1519, 2016. https://doi.org/10.1590/s0100-204x2016000900050

MENDONÇA, E. S.; MATOS, E. S. Matéria orgânica do solo: métodos de análises. Ponte Nova: D\&M, 2005. 107 p.

NASCIMENTO, H. E. M.; LAURANCE, W. F. Efeitos de área e de borda sobre a estrutura florestal em fragmentos de floresta de terra-firme após 13-17 anos de isolamento. Acta Amazonica, v. 36, n. 2, p. 183-192, 2006. https://doi.org/10.1590/S004459672006000200008

NOGUEIRA, L. R.; SILVA, C. F. D.; PEREIRA, M. G.; GOMES, J. H. G.; SILVA, E. M. R. D. Biological properties and organic matter dynamics of soil in pasture and natural regeneration areas in the Atlantic forest biome. Revista Brasileira de Ciência do Solo, v. 40, p. 1-9, 2016. https://doi.org/10.1590/18069657rbcs20150366

OBOUR, P. B.; JENSEN, J. L.; LAMANDÉ, M.; WATTS, C. W.; MUNKHOLM, L. J. Soil organic matter widens the range of water contents for tillage. Soil \& Tillage Research, v. 182, p. 57-65, 2018. https://doi.org/10.1016/j.still.2018.05.001

OZÓRIO, J. M. B.; ROSSET, J. S.; SCHIAVO, J.; PANACHUKI, E.; SOUZA, C. B. S.; MENEZES, R. S.; XIMENES, T. S.; CASTILHO, S. C. P.; MARRA, L. M. Estoque de carbono e agregação do solo sob fragmentos florestais nos biomas Mata Atlântica e Cerrado. Revista Brasileira de Ciências Ambientais, v. 3, n. 53, p. 97-116, 2019. https://doi.org/10.5327/Z2176-947820190518

PEREIRA, M. A. S.; NEVES, N. A. G. S. Considerações sobre a fragmentação territorial e as redes de corredores ecológicos. Geografia, v. 16, n. 2, p. 5-24, 2007. http://dx.doi.org/10.5433/2447-1747.2007v16n2p5

PRIMACK; R. B.; RODRIGUES, E. Biologia da Conservação. Londrina: Biblioteca Nacional, 2001. 328p.

R CORE TEAM. R: A language and environment for statistical computing. Vienna, 2019.

RANGEL, O. J. P.; SILVA, C. A. Estoques de carbono e nitrogênio e frações orgânicas de Latossolo submetido a diferentes sistemas de uso e manejo. Revista Brasileira de Ciência do Solo, v. 31, p. 1609-1623, 2007. https://doi.org/10.1590/S010006832007000600037

REINSCH, T.; LOGES, R.; KLUB, C.; TAUBE, F. Effect of grassland ploughing and reseeding on $\mathrm{CO} 2$ emissions and soil carbon stocks. Agriculture, Ecosystems \& Environment, v. 265, p. 374-383, 2018. https://doi.org/10.1016/j.agee.2018.06.020

REIS, D. A.; LIMA, C. L. R.; BAMBERG, A. L. Qualidade física e frações da matéria orgânica de um Planossolo sob sistema plantio direto. Pesquisa Agropecuária Brasileira, v. 51, n. 9, p. 1623-1632, 2016. https://doi.org/10.1590/s0100-204x2016000900062 
REIS, V. R. R.; DEON, D. S.; MUNIZ, L. C.; SILVA, M. B.; REGO, C. A. R. M.; GARCIA, U. C.; CANTANHÊDE, I. S. L.; COSTA, J. B. Carbon stocks and soil organic matter quality under different land uses in the maranhense amazon. Journal of Agricultural Science, v. 10, n. 5, p. 329-337, 2018. https://doi.org/10.5539/jas.v10n5p329

ROSSET, J. S.; LANA, M. C.; PEREIRA, M. G.; SCHIAVO, J. A.; RAMPIM, L.; SARTO, M. V. M.; SEIDEL, E. P. Estoque de carbono, propriedades químicas e físicas do solo em sistemas de manejo com diferentes tempos de implantação na Região Oeste do Paraná, Brasil. Semina: Ciências Agrárias, v. 35, n. 6, p. 3053-3072, 2014. http://dx.doi.org/10.5433/1679-0359.2014v35n6p3053

ROSSET, J. S.; ALBERTO, J. S.; MARRA, L. M.; CASTILHO, S. C. P.; OZÓRIO, J. M. B.; LIMA, P. R.; BORSOI, A. SOUZA, L. C. Carbono total e mineralizável do solo adubado com diferentes fontes de fertilizantes e resíduos orgânicos. Global Science and Technology, v. 12, n. 2, 2019a.

ROSSET, J. S.; LANA, M. C.; PEREIRA, M. G.; SCHIAVO, J. A.; RAMPIM, L.; SARTO, M. V. M. Organic matter and soil aggregation in agricultural systems with different adoption times. Semina: Ciências Agrárias, v. 40, n. 6, suplemento 3, p. 3443-3460, 2019b. http://dx.doi.org/10.5433/1679-0359.2019v40n6Supl3p3443

ROSSET, J. S.; LANA, M. C; PEREIRA, M. G.; SCHIAVO, J. A.; RAMPIM, L.; SARTO, M. V. M. Frações químicas e oxidáveis da matéria orgânica do solo sob diferentes sistemas de manejo, em Latossolo Vermelho. Pesquisa Agropecuária Brasileira, v. 51, n. 9, p. 1529-1538, 2016. https://doi.org/10.1590/s0100-204x2016000900052

SAlES, A.; SIlVA, A. R.; VElOSO, C. A. C.; CARVAlHO, E. J. M.; MIRANDA, B. M. Carbono orgânico e atributos físicos do solo sob manejo agropecuário sustentável na Amazônia Legal. Colloquium Agrariae, v. 14, n. 1, p. 1-15, 2018.

SANTOS, H. G.; JACOMINE, P. K. T.; ANJOS, L. H. C.; OLIVEIRA, V. A.; LUMBRERAS, J. F.; COELHO, M. R.; ALMEIDA, J. A.; ARAÚJO FILHO, J. C.; OLIVEIRA, J. B.; CUNHA, T. J. F. Sistema Brasileiro de Classificação de Solos. 5.ed. Brasília: Embrapa, 2018. 356p.

SIGNOR, D.; ZANI, C. F.; PALADINI, A. A.; DEON, M. D.; CERRI, C. E. P. Estoques de carbono e qualidade da matéria orgânica do solo em áreas cultivadas com cana-de-açúcar. Revista Brasileira de Ciência do Solo, v. 38, n. 5, p. 1402-1410, 2014. https://doi.org/10.1590/S0100-06832014000500005

SMITH, P. Soils and climate change. Current Opinion in Environmental Sustainability, v. 4, n. 5, p. 539-544, 2012. https://doi.org/10.1016/j.cosust.2012.06.005

SOUZA, A. C. O. D.; TORRES, R. B.; BERNACCI, L. C.; JUNG-MENDAÇOLLI, S. L. Species of native flora of the remnants from experimental stations of agência paulista de tecnologia dos agronegócios, Instituto Agronômico de Campinas, São Paulo State, Brazil. Hoehnea, v. 42, n. 1, p. 59-92, 2015. https://doi.org/10.1590/2236-8906-29/2014

SOUZA, F. G. D.; MELO, V. F.; ARAÚJO, W. F.; ARAÚJO, T. H. D. C. Losses of soil, water, organic carbon and nutrients caused by water erosion in different crops and natural savannah in the northern Amazon. Revista Ambiente \& Água, v. 14, n. 1, p. 1-16, 2019. https://dx.doi.org/10.4136/ambi-agua.2126 
SOUZA, L. C.; FERNANDES, C.; MOITINHO, M. R.; BICALHO, E. S.; SCALA, N. L. J. R. Soil carbon dioxide emission associated with soil porosity after sugarcane field reform. Mitigation and Adaptation Strategies for Global Change, v. 24, n. 1, p. 1-15, 2018. https://doi.org/10.1007/s11027-018-9800-5

SOUZA, R. P. B.; FREITAS, M. A. M.; COSTA, M. P.; PEREIRA, L. F.; GOMES, J. V. A. Impact of anthropic action on physical attributes of the soil in different physiology of $\begin{array}{lllllllll}\text { Cerrado. Multi-Science Journal, v. } 1, & \text { n. } & \text { 9, p. 28-32, } 2017 .\end{array}$ https://dx.doi.org/10.33837/msj.v1i9.380

SPEROW, M. Marginal cost to increase soil organic carbon using no-till on US cropland. Mitigation and Adaptation Strategies for Global Change, v. 23, p. 1-20, 2018. https://doi.org/10+1007/s11027-018-9799-7

VIANA, V. M.; PINHEIRO, L. A. F. V. Conservação da biodiversidade em fragmentos florestais. Série Técnica IPEF, v. 12, n. 32, p. 25-42, 1998.

VIANA, V. M.; TABANEZ, A. A. J.; BATISTA, J. L. F. Dynamics and restoration of forest fragments in the Brazilian Atlantic moist Forest. In: LAURANCE, W. F.; BIERREGARD, R. O. (ed.). Tropical forest remnants: ecology management and conservation of fragmented communities. Chicago: University of Chicago Press, 1997. p. 351-365.

WADE, J.; CULMAN, S. W.; HURISSO, T. T.; MILLER, R. O.; BAKER, L.; HORWATH, W. R. Sources of variability that compromise mineralizable carbon as a soil health indicator. Soil Science Society of America Journal, v. 82, p. 243-252, 2018. https://dx.doi.or/10.2136/sssaj2017.03.0105

WARBURTON, N. H. Structure and conservation of forest avifauna in isolated rainforest remnants in tropical Australia. In: LAURANCE W. F.; BIERREGAARD R. O. (eds). Tropical Forest Remnants. Chicago: University of Chicago Press, 1997. p. 190-206.

YEOMANS, J. C.; BREMNER, J. M. A rapid and precise method for routine determination of organic carbon in soil. Communications in Soil Science and Plant Analysis, v. 19, n. 13, p. 1467-1476, 2008. https://doi.org/10.1080/00103628809368027 


\begin{tabular}{|} 
Ambiente \& Água - An Interdisciplinary Journal of Applied Science \\
ISSN 1980-993X - doi:10.4136/1980-993X \\
www.ambi-agua.net \\
E-mail: ambi.agua@gmail.com
\end{tabular}

\title{
Application of a voltammetric enzymatic biosensor based on crude extract of Marasmiellus colocasiae for the detection of phenolic compounds in drinking water
}

\author{
ARTICLES doi:10.4136/ambi-agua.2610
}

Received: 28 Jun. 2020; Accepted: 28 Sep. 2020

\author{
Érica Aparecida Batista1 ${ }^{1}$; Luane Ferreira Garcia2 ${ }^{2}$; \\ Antonio João Carvalho de Albuquerque ${ }^{3(D)}$; Nara Ballaminut ${ }^{4}{ }^{(D}$; \\ Paulo Sérgio Scalize ${ }^{5 *}$; Eric Souza Gil ${ }^{2}$ iD
}
${ }^{1}$ Faculdade de Farmácia. Laboratório de Análise Farmacêutica e Ambientais (LAFAM). Universidade Federal de Goiás (UFG), Praça Universitária, nº 1166, CEP: 74605-220, Goiânia, GO, Brazil. E-mail: ericabatistaquim@gmail.com
${ }^{2}$ Faculdade de Farmácia. Universidade Federal de Goiás (UFG), Rua 240, s/n, CEP: 74605-170, Goiânia, GO, Brazil. E-mail: luane.fg@hotmail.com, ericsgil@gmail.com
${ }^{3}$ Departamento de Engenharia Civil e Arquitetura. Faculdade de Engenharia. Universidade da Beira Interior (UBI), Calçada Fonte do Lameiro, 6201-001, Covilhã, Portugal. E-mail: antonio.albuquerque@ubi.pt
${ }^{4}$ Escola de Engenharia Civil e Ambiental. Laboratório de Análise de Água. Universidade Federal de Goiás (UFG), Avenida Universitária, Quadra 86, CEP: 74605-220, Goiânia, GO, Brazil.
E-mail: naraballaminut@msn.com
${ }^{5}$ Escola de Engenharia Civil e Ambiental. Departamento de Hidráulica e Saneamento. Universidade Federal de Goiás (UFG), Avenida Universitária, Quadra 86, CEP: 74605-220, Goiânia, GO, Brazil.
*Corresponding author. E-mail: pscalize.ufg@gmail.com

\begin{abstract}
The chemical and pharmaceutical industries are the main generators of residues, such as phenolic microcontaminants, including catechol, resorcinol, p-nitrophenol and 4-chlorophenol. Therefore, this work aims to identify these microcontaminants through an emerging contaminant biosensor by means of an enzymatic biosensor constructed with an enzymatic extract from the fungus Marasmiellus colocasiae. Based on the differential pulse voltammetry electrochemical technique, the biosensor was used to analyze the patterns of catechol, resorcinol, p-nitrophenol and 4-chlorophenol. The analysis of a sample prepared with these standards in water from the public supply network was also carried out. As a result, it was possible to verify that the biosensor developed in this study is more sensitive than conventional methods and has a greater affinity for catechol. In the sample prepared with the standards, it was possible to qualitatively identify the presence of 4-chlorophenol, resorcinol and catechol. The proposed biosensor was sensitive and has potential for application in the analysis of microcontaminants in the environment with the detection limit $=0.17 \mu \mathrm{mol} \mathrm{L}^{-1}$, and the quantification limit $=0.52 \mu \mathrm{mol} \mathrm{L}-1$.
\end{abstract}

Keywords: electrochemical biosensor, micropollutants, polyphenol oxidases, potable water. 


\section{Aplicação de um biosensor enzimático voltamétrico à base de extrato bruto de Marasmiellus colocasiae para a detecção de compostos fenólicos em água potável}

\section{RESUMO}

As indústrias químicas e farmacêuticas são as principais geradoras de resíduos, como microcontaminantes fenólicos, dentre eles catechol, resorcinol, p-nitrophenol e 4-chlorophenol. Diante disso, este trabalho objetiva identificar estes microcontaminantes através de um biossensor de contaminantes emergentes por meio de um biossensor enzimático construído com extrato enzimático do fungo Marasmiellus colocasiae. A partir da técnica eletroquímica de voltametria de pulso diferencial, o biossensor foi utilizado para analisar os padrões de catechol, resorcinol, p-nitrophenol e 4-chlorophenol. Também foi realizada a análise de uma amostra preparada com estes padrões em água da rede de abastecimento coletivo. Como resultado, foi possível verificar que o biossensor desenvolvido nesse estudo é mais sensível que os métodos convencionais e apresenta maior afinidade para o catechol. Na amostra preparada com os padrões foi possível identificar qualitivamente a presença do o 4-chlorophenol, resorcinol e catechol. O biossensor proposto foi sensível e apresenta potencial para aplicação na análise de microcontaminantes no meio ambiente com o limite de detecção $=0.17 \mu \mathrm{mol} \mathrm{L}^{-1}$ e limite de quantificação $=0.52 \mu \mathrm{mol} \mathrm{L}-1$.

Palavras-chave: biossensor eletroquímico, micropoluentes, polifenol oxidases.

\section{INTRODUCTION}

Chemical and pharmaceutical industrial activities produce micropollutants resistant to biodegradation, most of them hazardous compounds, that are often discharged into water resources through untreated or improperly treated wastewaters. Many of these compounds are not removed by traditional wastewater treatment technologies, and their presence in natural waters, even in small concentrations, limits their use, which can cause public health risks and negative environmental impacts (Gosset et al., 2018; Ooi et al., 2020).

Many compounds have a high potential for contamination, even at low concentrations, for water, soil and air, and are called "emerging contaminants" (ECs) or "emerging pollutants", with increasing concern for the water quality of water resources and drinking water supplied to the population (Conama, 2013).

Currently, it is estimated that there are more than 700 emerging pollutants in the water resources, compounds of chemical and synthetic origin, with dangerous potential for the environment and public health, and whose monitoring is deficient. Within these, there should be highlighted the phenolic compounds such as catechol, 2-chlorophenol, 4-nitrophenol, resorcinol, which are documented as being highly toxic to biota (Carvalho and Orlanda, 2017).

There is an urgent need for the development and application of tools for detecting and quantifying these micropollutants in the environment, with biosensor technology emerging as a potential resource for this purpose. These biosensors detect molecules by means of biological components such as enzymes, DNA, antibodies and aptamers with which they interact, forming measurable electrochemical and optical signals (Lobsiger et al., 2019).

Enzymatic biosensors are defined as biologically modified sensors where enzymes selectively interact with the substrate. The laccase enzyme (EC 1.10.3.2) is an oxidoreductase, which acts mainly on diphenols and has oxygen as its final electron acceptor, being then widely used as an analytical tool for food, environmental and biomedical analysis (Kavetskyy et al., 2019). This enzyme has a multi-colored active site interacting with phenolic compounds and 
can be immobilized by physical adsorption in biosensors. Laccase is found in plants and in some microorganisms (Simón-Herrero et al., 2019).

Marasmiellus colocasiae is a basidiomycete that has ligninolytic enzymes such as laccases, total peroxidases and metal chelating micronutrients, characterized as a pathogen of the araceae Colocasia esculenta, popularly known as taro and coconut yam, and is an important source of amino acids, minerals, vitamins and proteins (Capelari et al., 2010; Vidigal et al., 2016).

The European Union and the American Environmental Protection Agency have cataloged several emerging phenolic micropollutants originating from wastewaters from the pharmaceutical and cosmetic industries, such as the catechol, 4-nitrophenol and resorcinol, which can be harmful to health and can cause skin irritations, respiratory and ophthalmic problems and can be precursors of cancerous diseases or act as endocrine disruptors. The 2chlorophenol, generated in the paper and cellulose industries, is toxic and bioaccumulative in aquatic species (Song et al., 2019).

This work aimed to develop an enzymatic biosensor with $M$. colocasiae extract, which presents a different designer of sensor optimized to detect and quantify the presence of catechol, resorcinol, p-nitrophenol and 4-chlorophenol in water preparations prepared with these compounds.

\section{MATERIALS AND METHODS}

\subsection{Origin and maintenance of the fungus}

The fungus Marasmiellus colocasiae CCIBT 3388, isolated in Domingos MartinsES/2005, was obtained from the Basidiomycete Culture Collection (CCB) of the São Paulo Institute of Botany. The identification of the obtaining source ex situ of genetic heritage, with the information contained in the records, is in accordance with $\S 1$ of the Article 22 of the Decree $\mathrm{N}^{\mathrm{o}} 8.772$ of 2016.

The microorganism was placed in Petri dishes containing $1.5 \%$ of agar culture medium $\left(\right.$ Biolog $\left.{ }^{\circledR}\right), 2 \%$ of malt extract $\left(\right.$ Biolog $\left.^{\circledR}\right), 1 \%$ of dextrose $\left(\right.$ Greentec $^{\circledR}$ ) and $0.1 \%$ of bacteriological peptone $\left(\right.$ Biolog $^{\circledR}$ ), in an oven at $28^{\circ} \mathrm{C}$ for 7 days, greenhouse SX350 Sterilifer ${ }^{\circledR}$ obtained in the United States of America.

\subsection{Enzyme production}

For the production of the crude enzymatic extract, 15 discs ( $5 \mathrm{~mm}$ in diameter) of $M$. colocasiae mycelo were used, in a $250 \mathrm{ml}$ conical flask, containing $100 \mathrm{ml}$ of the culture medium ( $2 \%$ of malt extract, $1 \%$ of dextrose and $0.1 \%$ of bacteriological peptone). Sterilization conditions were carefully maintained. Then, the flasks were incubated and kept in an oven at $28^{\circ} \mathrm{C}$ for 15 days.

After the incubation period, the content obtained was filtered with the aid of a vacuum pump (Prismatec-131 ${ }^{\circledR}$, Brazil), in a filtration system with $0.45 \mu \mathrm{m}$ cellulose nitrate membrane and $47 \mathrm{~mm}$ in diameter $\left(\right.$ Unifil $\left.^{\circledR}\right)$. The enzymatic extract was used for the determination of enzymatic activity and for the composition of the biosensor.

\subsection{Enzymatic activity determination}

\subsubsection{Total Polyphenoloxidase Determination (TPO)}

To determine the enzymatic activity of total TPO, the reaction solution contained $3000 \mu \mathrm{L}$, with $750 \mu \mathrm{L}$ of $100 \mathrm{mM}$ sodium acetate buffer $\mathrm{pH} 5.0 ; 1800 \mu \mathrm{L}$ and enzymatic extract of $M$. colocasiae; $150 \mu \mathrm{L}$ of $2 \mathrm{mM} \mathrm{H}_{2} \mathrm{O}_{2}\left(\right.$ Synth $\left.^{\circledR}\right)$; $300 \mu \mathrm{L}$ of $0.03 \%$ ABTS (Sigma Aldrich ${ }^{\circledR}$ ). For some extracts, it was necessary to dilute the sample in a buffer for proper determination.

The enzymatic activity was carried out in a spectrophotometer at $420 \mathrm{~nm}$ and a reaction time of $10 \mathrm{~min}$. An enzyme unit was defined as the amount of enzyme needed to oxidize $1 \mu \mathrm{mol}$ of substrate per liter per minute (Machado and Matheus, 2006; Zeraik et al., 2008). 


\subsubsection{Laccase activity determination}

For the determination of the enzymatic activity of the laccase, the reaction solution contained $3000 \mu \mathrm{L}$, with $850 \mu \mathrm{L}$ of $100 \mathrm{mM}$ sodium acetate buffer $\mathrm{pH} 5.0,1800 \mu \mathrm{L}$ and enzymatic extract of $M$. colocasiae and $50 \mu \mathrm{L}$ of commercial bovine catalase (Sigma Aldrich ${ }^{\circledR}$ ). After 5 min of reaction with the catalase, $300 \mu \mathrm{L}$ of $0.03 \%$ ABTS (Sigma Aldrich ${ }^{\circledR}$ ) was added. For some extracts, it was necessary to dilute the sample in a buffer for proper determination. The enzymatic activity was monitored for $10 \mathrm{~min}$ in a spectrophotometer at $420 \mathrm{~nm}$ (Machado an Matheus, 2006; Zeraik et al., 2008).

\subsubsection{Total peroxidase activity determination}

To determine total peroxidases, the following formula was used: Total peroxidases $=$ total TPO - Laccases, in which there is a subtraction of enzymatic activities (Eggert et al., 1996).

\subsection{Biosensor preparation}

A proportion of $50 \mu \mathrm{L}$ of crude enzyme extract and $70 \mathrm{mg}$ of graphite powder (Sigma Aldrich $\left.{ }^{\circledR}\right)$ was used. The mixture was homogenized and dried at room temperature $\left(28 \pm 2^{\circ} \mathrm{C}\right)$. Then, $30 \mathrm{mg}$ of mineral oil (Sigma Aldrich ${ }^{\circledR}$ ) was added, forming an agglutinated paste, which was vigorously homogenized and added to a support electrode with a cavity of $2 \mathrm{~mm}$ in diameter and $0.5 \mathrm{~mm}$ in depth. As a control, a sensor containing only graphite powder and mineral oil was prepared. The carbon paste was manually renewed for each analysis, in order to guarantee the effectiveness and reproducibility of the results.

\subsection{Electrochemical determination}

Voltammetric analyses were performed on a PGSTAT ${ }^{\circledR}$ Model 204 potentiostat/galvanostat (Metrohm Autolab, Utrecht Netherlands) integrated with the NOVA $2.1^{\circledR}$ software. The experiments were carried out in an electrochemical cell with a capacity of $10 \mathrm{~mL}$, containing $2 \mathrm{~mL}$ of $100 \mathrm{mmol} \mathrm{L}^{-1}$ of sodium acetate buffer solution, at $\mathrm{pH} 5$ and analyte, in a three-electrode system, with the biosensor being the electrode of work $(\varnothing=2 \mathrm{~mm})$, the $\mathrm{Pt}$ wire the auxiliary electrode and finally the $\mathrm{Ag} / \mathrm{AgCl} / \mathrm{KCl}_{\text {sat }} 3 \mathrm{~mol} \mathrm{~L}^{-1}$ the reference electrode.

For conditioning the working electrode, a cyclic voltammetry technique was used. The operating conditions were 10 successive cycles in a $100 \mathrm{mmol} \mathrm{L}^{-1}$ sodium acetate buffer solution, $\mathrm{pH} 5.0$, with a sweep speed of $50 \mathrm{mV} \mathrm{s}^{-1}$ and a potential range from 0 to $1 \mathrm{~V}$. The differential pulse voltammetry technique was chosen for the analyses. Operating conditions included a pulse amplitude of $50 \mathrm{mV}$, pulse width of $0.5 \mathrm{~s}$ and scan speed of $10 \mathrm{mV} \mathrm{s}$. The experiments were carried out at room temperature $\left(28 \pm 2^{\circ} \mathrm{C}\right)$, in triplicate $(\mathrm{n}=3)$, and the electrolyte solution used was a buffer solution of sodium acetate $\left(100 \mathrm{~m} \mathrm{~mol} \mathrm{~L}^{-1}\right.$, at $\left.\mathrm{pH} 5.0\right)$. The results obtained were analyzed and treated with the aid of the Origin $9^{\circledR}$ software.

\subsection{Determination of phenolic micropollutants, calibration curve, detection limit and analysis in synthetic water sample}

The phenolic micropollutants selected in this investigation were the 4-chlorophenol (PM $=127.5 \mathrm{~g}$ mol-1), p-nitrophenol $\left(\mathrm{PM}=139.11 \mathrm{~g} \mathrm{~mol}^{-1}\right)$, catechol $\left(\mathrm{PM}=110.11 \mathrm{~g} \mathrm{~mol}^{-1}\right)$ and resorcinol $\left(\mathrm{PM}=110.11 \mathrm{~g} \mathrm{~mol}^{-1}\right)$, purchased from Sigma Aldrich ${ }^{\circledR}$. An initial solution of 10 mmol L ${ }^{-1}$ of each compound was prepared for the tests. Through differential pulse voltammetry, the biosensor was used for checking the improvement of the analytical signal. The calibration curve and the detection limit were obtained with the catechol compound in the range of 50 to $300 \mu \mathrm{mol} \mathrm{L} \mathrm{L}^{-1}$, in a sodium acetate buffer solution $\left(100 \mathrm{~mol} \mathrm{~L}^{-1}\right.$, at $\left.\mathrm{pH} 5.0\right)$.

The synthetic water was collected at the Faculty of Pharmacy, at the Federal University of Goiás - UFG, composed of elements with compounds $\mathrm{mg} \mathrm{L}^{-1} \mathrm{Al} 0.5$, As 0.8; B 0.07; Ba 0.02; $\mathrm{Ca}$ 40; Cu 1.0; K 2.0; Li 0.02; Mg 17.0; Mn 0.03, Mo 0.09; Na 29; Pb 0.2; S 4.4; Sb 0.04; Sr 0.4; U 0.03, Zn 0.5. The compounds Ag, Be, Co, Cr, Fe, Hg, Ni, P, Sn, Ti, V did not present 
significant amounts.

Tests were carried out on simulated samples, with the four compounds being added to 2 $\mathrm{mL}$ of water from the public supply network in the city of Goiânia-GO, collected in the building of the Faculty of Pharmacy (UFG). The compounds were added in concentrations of $1300 \mu \mathrm{mol}$ $\mathrm{L}^{-1}$, for the 4-chlorophenol and the p-nitrophenol, $160 \mu \mathrm{mol} \mathrm{L}{ }^{-1}$ for the catechol and $330 \mu \mathrm{mol}$ $\mathrm{L}^{-1}$ for the resorcinol.

Different concentrations were chosen because the biosensor has a different affinity for each micropollutant, since it is an enzymatic matrix. From the prepared samples, aliquots of $100 \mu \mathrm{L}, 150 \mu \mathrm{L}, 250 \mu \mathrm{L}$ and $350 \mu \mathrm{L}$ were added to the electrochemical cell containing $2 \mathrm{~mL}$ of sodium acetate buffer solution $\left(100 \mathrm{~mol} \mathrm{~L}^{-1}\right.$, at $\left.\mathrm{pH} 5.0\right)$ to perform analysis in triplicate by the biosensor, the concentrations of the micropollutants were obtained by means of serial dilution, using a $1 \mathrm{mM}$ mother solution.

\section{RESULTS AND DISCUSSION}

The crude enzymatic extract obtained from the $M$. colocasiae used showed enzymatic activity of $1286.20 \pm 183.91 \mathrm{U} \mathrm{L}^{-1}$ for phenoloxidase enzymes, $389.79 \pm 66.31 \mathrm{U} \mathrm{L}^{-1}$ for laccase enzymes and $896.41 \pm 190.27 \mathrm{U} \mathrm{L}^{-1}$ for peroxidase enzymes. Therefore, the optimal conditions for the development of the biosensor were reached (Figure 1).
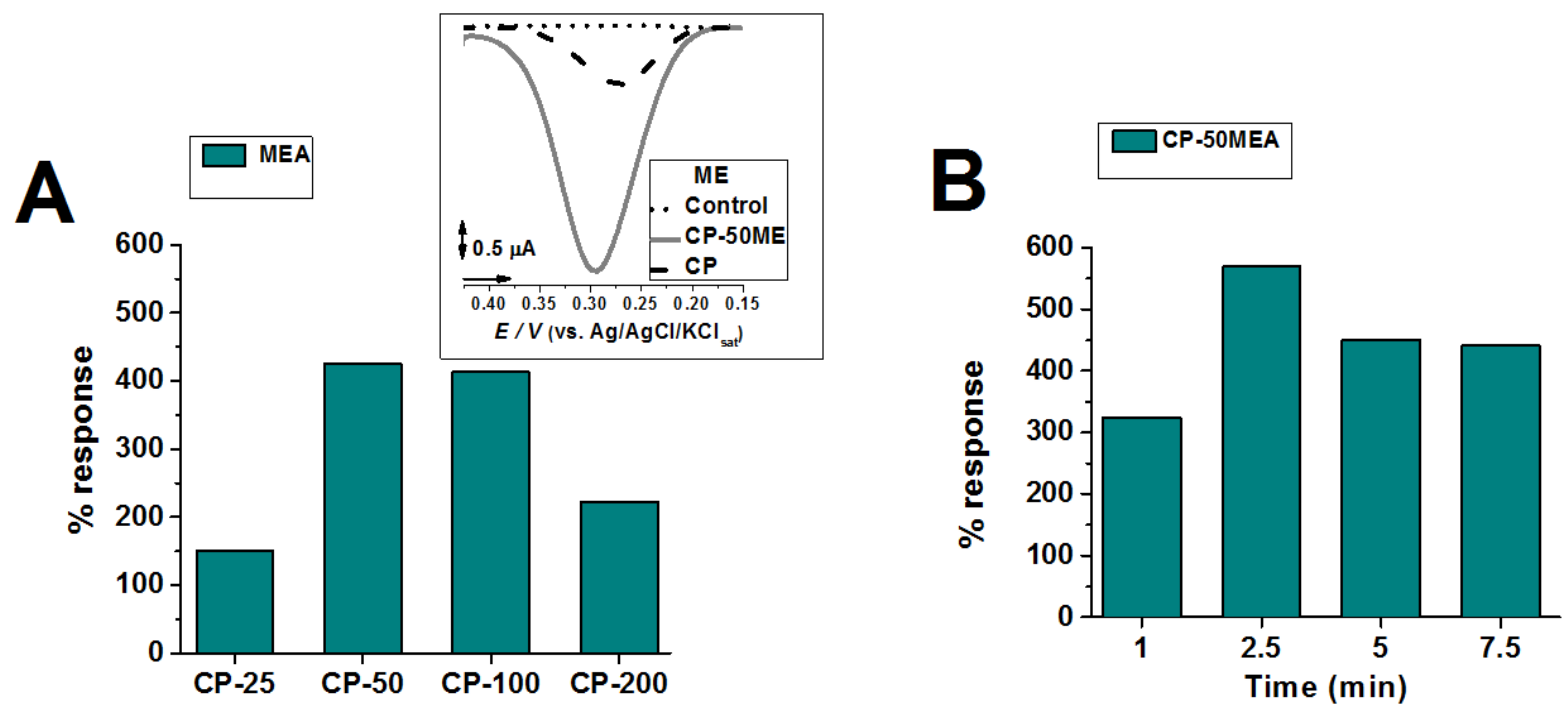

Figure 1. Optimization of biosensors with crude enzymatic extracts. A: enzymatic extracts obtained from minimal liquid medium (ME) in different proportions $(25,50,100$ or $200 \mu \mathrm{L}$ in $70 \mathrm{mg}$ of graphite) in the construction of biosensors, tested with the $10 \mu \mathrm{mol} \mathrm{L-1}$ catechol substrate. Insertion: CP-50ME and CP without modification in the analysis of the $10 \mu \mathrm{mol} \mathrm{L-1}$ catechol. B: Different enzyme reaction times of the biosensors in the $10 \mu \mathrm{mol} \mathrm{L}-1$ catechol solution, before electrochemical analysis. All testicles were performed in $100 \mathrm{mmol} \mathrm{L-1}$ sodium acetate buffer $\mathrm{pH}$ 5.0.

The sodium acetate buffer $\mathrm{pH} 5.0$ was used in accordance with the literature that uses the variation of 4.5 to 5.0 for the use of fungal enzymes in the use of electrochemical remedies and in biosensors, optimizing the utility of the enzyme, resulting in better oxidation (Kolomytseva et al., 2017; 2019; Mishra et al., 2017).

Through the Differential Pulse Voltammetry technique, the enzymatic sensor and the biosensor were tested for the detention of the four micropollutants (catechol, resorcinol, pnitrophenol and 4-chlorophenol) under the same conditions, as shown in Figure 2.

The minimal liquid culture medium of $M$. colocasiae was incubated in order to obtain crude enzymatic extracts containing high TPO activity. Biosensors with different options were tested with the catechol substrate (Figure 2-A). From these results, which show the best 
analytical responses for electrochemical reduction of the substrate with the biosensors with the culture medium, CP-50ME was selected for analysis of the enzymatic reaction times of the biosensor with the substrate, to promote biochemical oxidation, before electrochemical reduction (Figure 2-B).
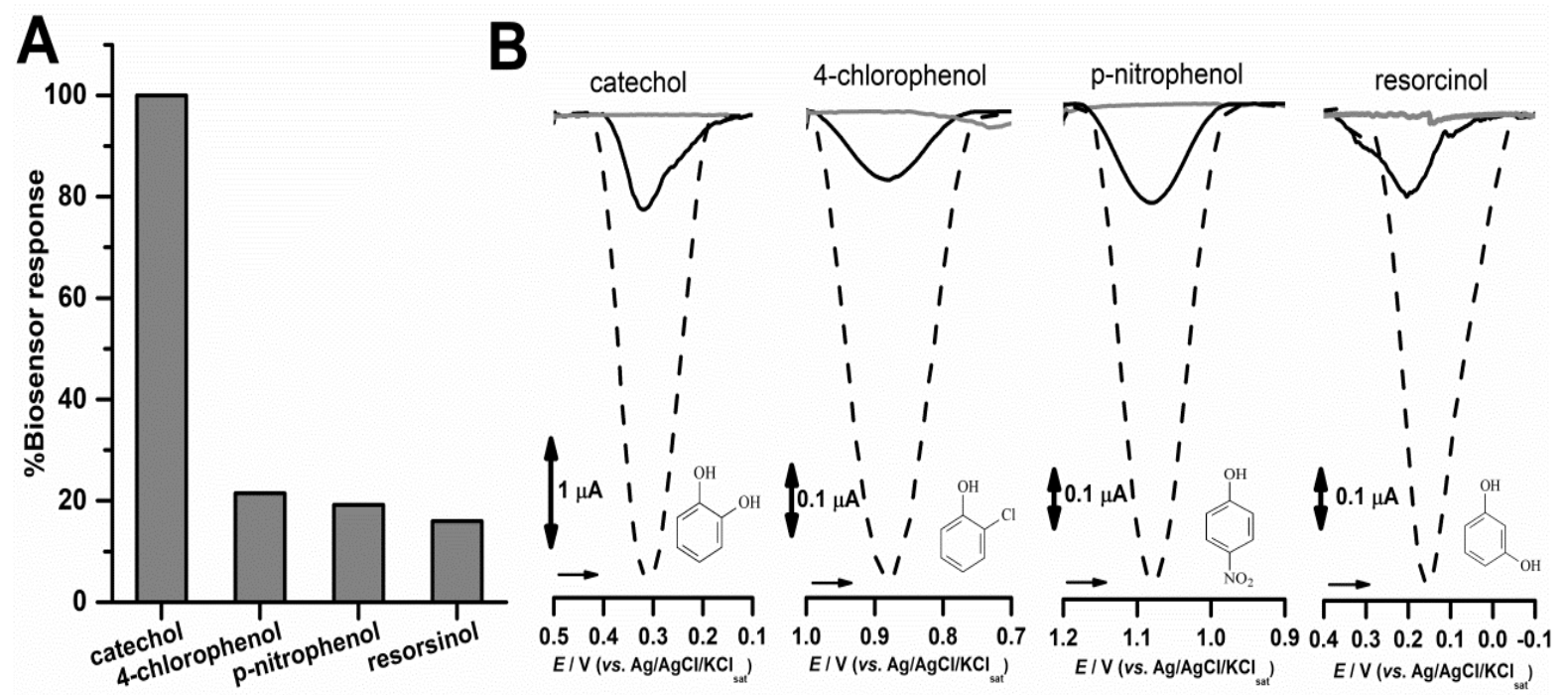

Figure 2. (A) Affinity of the biosensor for different phenolic compounds. (B) Determination of phenolic compounds at $100 \mu \mathrm{mol} \mathrm{L}^{-1}$ in a sodium acetate buffer solution $\left(100 \mathrm{mmol} \mathrm{L}^{-1}, \mathrm{pH} 5.0\right)$ by differential pulse voltammetry for sensor (-), enzymatic biosensor (- - ) and control (-).

Thus, it was possible to notice a higher biosensor specificity for the catechol (100\%), followed by the 4-chlorophenol $(21.45 \%)$, the p-nitrophenol $(19.20 \%)$ and the resorcinol $(15.96 \%)$ (Figure 2 - A). It was also possible to observe an improvement of about six times for each compound analyzed with the biosensor, when compared to the conventional sensor (Figure 2 - B). Catechol, as a diphenol, may explain the greater specificity of enzymes present in the biosensor, according to other polyphenol oxidases present in the literature (Benaceur et al., 2019; Han et al., 2019). The same is not applied to the resorcinol, another diphenol, which may be related to decreased affinity due to the position of the hydroxyls in the aromatic ring when in contact with the active site of the enzymes present in this crude extract.

In Figure 3, it is possible to observe that each compound has a reduction potential, being $0.15 \mathrm{~V}$ for the resorcinol, $0.30 \mathrm{~V}$ for the catechol, $0.88 \mathrm{~V}$ for the 4-chlorophenol and $1.08 \mathrm{~V}$ for the p- nitrophenol. Gan et al. (2019), using an electrochemical sensor for detecting different phenolic compounds, have observed oxidation potentials of $0.36 \mathrm{~V}$ for 4 -aminophenol, $0.89 \mathrm{~V}$ for the 4-chlorophenol and 1.17 V for the 4-nitrophenol. These compounds are reversible, since phenols are oxidized by enzymes and reduced by electrochemical technique in similar potentials.

Through serial dilution using a $1 \mathrm{mM}$ mother solution, concentrations of $1300 \mu \mathrm{mol} \mathrm{L} \mathrm{L}^{-1}$ were obtained for 4-chlorophenol and p-nitrophenol, $160 \mu \mathrm{mol} \mathrm{L}^{-1}$ for catechol and $330 \mu \mathrm{mol}$ $\mathrm{L}^{-1}$ for resorcinol. The catechol showed better responses and through it a calibration curve was made, since this compound is considered the gold standard in micropollutant analyses (Han et al., 2019).

A calibration curve (Figure 4) was developed based on the best response presented to the biosensor, the catechol compound, in order to assess whether the proposed method presented a linear response to the increase in analyte concentration. The Table 1 presents the results obtained in this work in comparison with those observed in other similar works. 


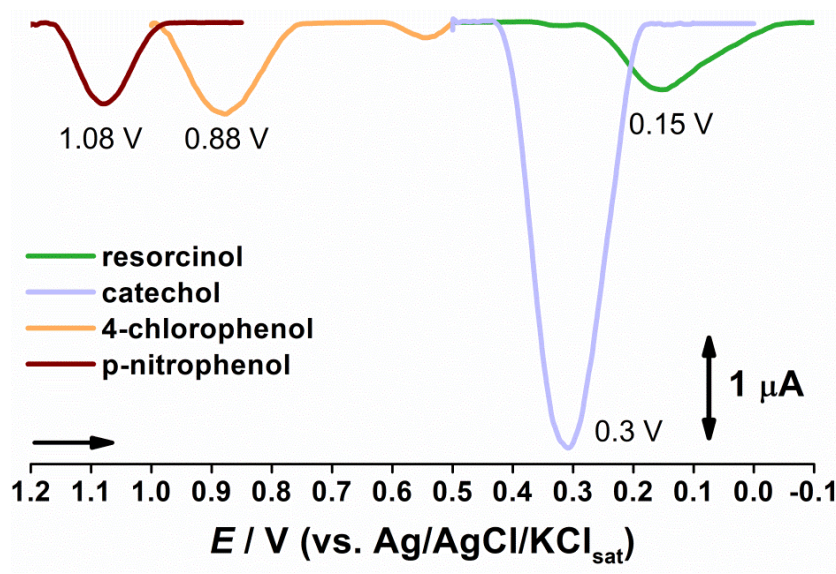

Figure 3. Different reduction ranges for the phenolic compounds: resorcinol, catechol, 4-chlorophenol and p-nitrophenol obtained by the enzymatic biosensor in a $100 \mu \mathrm{mol} \mathrm{L}^{-1}$ of sodium acetate buffer solution (100 mmol L-1, pH 5.0).

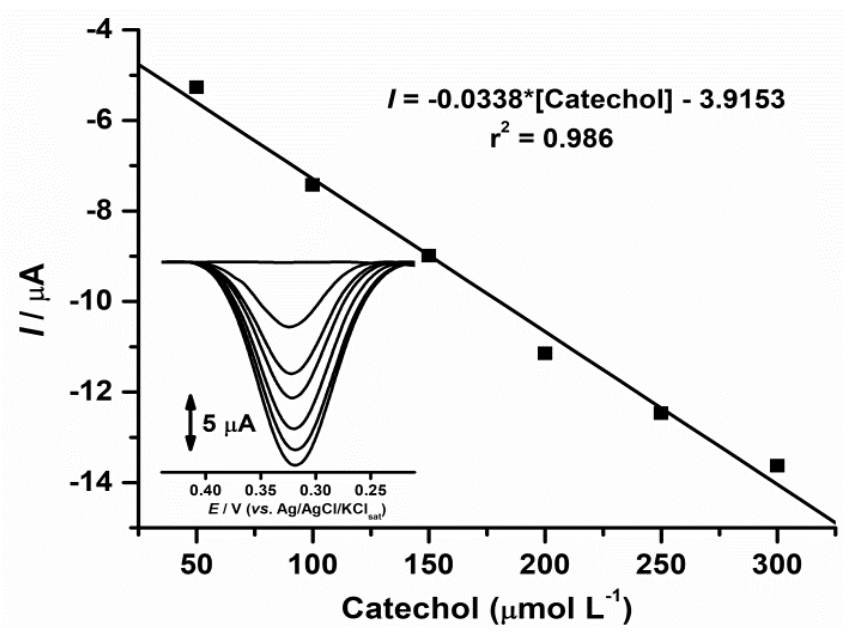

Figure 4. Calibration curve with the enzymatic biosensor for the catechol (50 to $\left.300 \mu \mathrm{mol} \mathrm{L}^{-1}\right)$. Detection limit $=0.17 \mu \mathrm{mol} \mathrm{L}^{-1}$; Quantification limit $=$ $0.52 \mu \mathrm{mol} \mathrm{L}^{-1}$.

Table 1. Comparison of the results obtained with the biosensor developed in this research with other polyphenol oxidases immobilized electrodes towards catechol detection.

\begin{tabular}{|c|c|c|c|c|c|}
\hline Enzyme source & $\begin{array}{l}\text { Enzymatic } \\
\text { activity }\end{array}$ & Method & $\begin{array}{l}\text { Linear range } \\
(\mu \mathrm{mol} \mathrm{L}-1)\end{array}$ & $\begin{array}{l}\text { Limit of detection } \\
\qquad\left(\mu \mathrm{mol} \mathrm{L}^{-1}\right)\end{array}$ & Reference \\
\hline M. colocasiae & $1286.20 \mathrm{U} \mathrm{L}^{-1}$ & DPV & $50-300$ & 0.17 & This work \\
\hline $\begin{array}{l}\text { Jenipapo Fruit } \\
\text { (Genipa } \\
\text { americana L.) }\end{array}$ & $\begin{array}{c}593 \\
\mathrm{U} \mathrm{mg}^{-1}\end{array}$ & DPV & $10-310$ & 7 & $\begin{array}{c}\text { (Antunes et al. } \\
\text { 2018) }\end{array}$ \\
\hline Mushrooms & $\begin{array}{c}1530 \\
\mathrm{UI} \mathrm{mg}^{-1}\end{array}$ & Amperometric & $0.5-24.0$ & 0.3 & $\begin{array}{c}\text { (Hervás Pérez et } \\
\text { al., 2006) }\end{array}$ \\
\hline $\begin{array}{l}\text { Manilkara Z. } \\
\text { (sapota) } \\
\text { Fruit }\end{array}$ & $620 \mathrm{U}$ & $\begin{array}{c}\text { Chrono } \\
\text { amperometric }\end{array}$ & $1.0-15.0$ & 0.47 & $\begin{array}{c}\text { (Sandeep et al. } \\
\text { 2019) }\end{array}$ \\
\hline $\begin{array}{c}\text { Agaricus } \\
\text { bisporus }\end{array}$ & - & Amperometric & $0.5-101$ & 0.15 & $\begin{array}{c}\text { (Sethuraman } \text { et } \\
\text { al., 2013) }\end{array}$ \\
\hline $\begin{array}{l}\text { Purchased from } \\
\text { Sigma }\end{array}$ & $1050 \mathrm{U} \mathrm{mg}^{-1}$ & $\begin{array}{c}\text { Cyclic } \\
\text { voltammetry }\end{array}$ & $1.0-100$ & 0.01 & $\begin{array}{l}\text { (Chen et al. } \\
\text { 2013) }\end{array}$ \\
\hline
\end{tabular}


Thus, using drinking water, four phenolic micropollutants and a biosensor based on $M$. colocasiae, a very good detection and quantification of catechol in concentrations from 15.71 $\mu \mathrm{mol} \mathrm{L}-1$ (100 $\mu \mathrm{L}$ of solution) to $49.15 \mu \mathrm{mol} \mathrm{L}^{-1}$ (350 $\mu \mathrm{L}$ of solution) was observed. Resorcinol and 4-chlorophenol were also detected, whereas their quantification was hampered by the low sensitivity. In fact, the expected concentrations would be below the limit of quantification of the proposed biosensor. Regarding p-nitrophenol, the low sensitivity of the biosensor for this compound, and its poor aqueous solubility, hampered its detection (Ramesh et al., 2018).

The results showed that the proposed methodology and M. colocasiae-based biosensor are sensitive for the detection of catechol, resorcinol and the 4-chlorophenol micropollutants, for low detection limits and a wide range of linearity. The biosensor may exhibit different behaviors in contact with the analyzed compounds. The enzyme may therefore have greater affinity for a substrate with greater solubility (Figure 5).

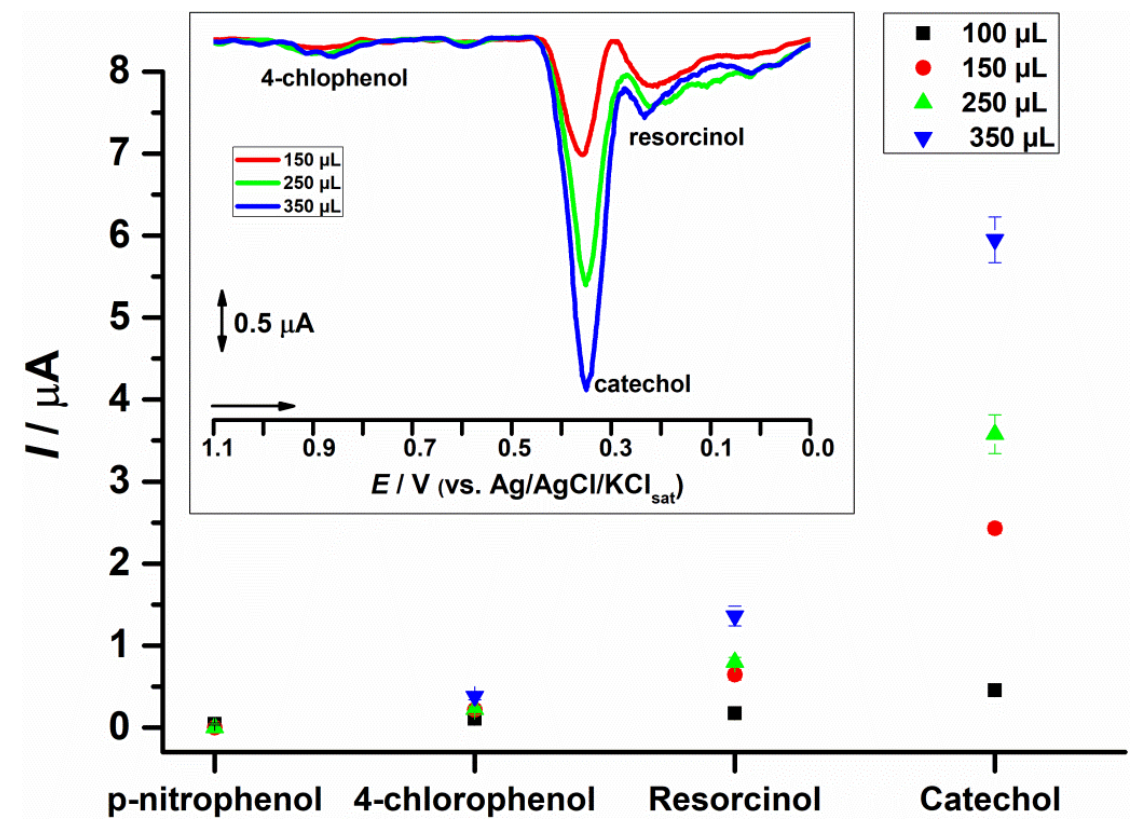

Figure 5. Detection curve for the four compounds in water samples from the public supply network, prepared in different concentrations in a sodium acetate buffer solution (100 $\left.\mathrm{mmol} \mathrm{L}^{-1}, \mathrm{pH} 5.0\right)$.

\section{CONCLUSIONS}

The M. colocasiae-based biosensor developed for this research work was efficient in the detection and quantification of catechol and in the detection of resorcinol and 4-chlorophenol, in samples prepared with water from the public supply network. The biosensor covers the linear range of 50 to $300 \mu \mathrm{mol} \mathrm{L} \mathrm{L}^{-1}$, with the detection limit $=0.17 \mu \mathrm{mol} \mathrm{L}^{-1}$, and the quantification limit $=0.52 \mu \mathrm{mol} \mathrm{L} \mathrm{L}^{-1}$. Thus, this biosensor can be considered innovative and can be an interesting technology for the detection and quantification of micropollutants in water resources and water supply systems.

\section{ACKNOWLEDGMENTS}

The Coordenação de Aperfeiçoamento de Pessoal de Nível Superior (CAPES), the postgraduate program in Pharmaceutical Sciences (PPGCF) of the Federal University of Goiás, the Laboratory of Pharmaceutical and Environmental Analysis (LAFAm), and the Water Analysis Laboratory (LaNA). 


\section{REFERENCES}

ANTUNES, R. S. et al. Development of a polyphenol oxidase biosensor from Jenipapo fruit extract (Genipa americana L.) and determination of phenolic compounds in textile industrial effluents. Biosensors, v. 8, n. 2, 2018. https://doi.org/10.3390/bios8020047

BENACEUR, F. et al. Purification and characterization of catechol oxidase from Tadela (Phoenix dactylifera L.) date fruit. International Journal of Biological $\begin{array}{llllll}\text { Macromolecules, } & \text { v. } & 125, & \text { p. } & 1248-1256, & \end{array}$ https://doi.org/10.1016/j.ijbiomac.2018.09.101

CAPELARI, M. et al. A new pathogenic species of Marasmiellus from Brazil. Cryptogamie, Mycologie, v. 31, n. 2, p. 137-142, 2010.

CARVALHO, J. A.; ORLANDA, J. Heat stability and effect of $\mathrm{pH}$ on enzyme activity of polyphenol oxidase in buriti (Mauritia flexuosa Linnaeus f.) fruit extract. Food Chemistry, v. 233, p. 159-163, 2017. https://doi.org/10.1016/j.foodchem.2017.04.101

CHEN, H. et al. A new catechol biosensor immobilized polyphenol oxidase by combining electropolymerization and cross-linking process. International Journal of Polymeric Materials and Polymeric Biomaterials, v. 62, n. 12, p. 620-626, 2013. https://doi.org/10.1080/00914037.2012.761629

CONAMA (Brasil). Resolução $n^{\circ} 460$ de 30 de dezembro de 2013. Altera a Resolução CONAMA $n^{\circ} 420$, de 28 de dezembro de 2009, que dispõe sobre critérios e valores orientadores de qualidade do solo quanto à presença de substâncias químicas e dá outras providências. Diário Oficial [da] União: seção 1, Brasília, DF, n. 253, p. 153, 31 dez. 2013.

EGGERT, C.; TEMP, U.; ERIKSSON, K. E. L. The ligninolytic system of the white rot fungus Pycnoporus cinnabarinus: Purification and characterization of the laccase. Applied and Environmental Microbiology, v. 62, n. 4, p. 1151-1158, 1996.

GAN, T. et al. Morphology-dependent electrochemical activity of $\mathrm{Cu} 2 \mathrm{O}$ polyhedrons and construction of sensor for simultaneous determination of phenolic compounds with graphene oxide as reinforcement. Sensors and Actuators B: Chemical, v. 282, p. 549558, 2019. https://doi.org/10.1016/j.snb.2018.11.102

GOSSET, A. et al. Xurography-based microfluidic algal biosensor and dedicated portable measurement station for online monitoring of urban polluted samples. Biosensors and Bioelectronics, v. 117, p. 669-677, 2018. https://doi.org/10.1016/j.bios.2018.07.005

HAN, Q. Y. et al. Comparison of biochemical properties of membrane-bound and soluble polyphenol oxidase from Granny Smith apple (Malus $\times$ domestica Borkh.). Food $\begin{array}{llllll}\text { Chemistry, } & \text { v. 289, n. } & \text { 17, } & \text { p. }\end{array}$ https://doi.org/10.1016/j.foodchem.2019.02.064

HERVÁS PÉREZ, J. P. et al. Amperometric tyrosinase biosensor based on polyacrylamide microgels. Biosensors and Bioelectronics, v. 22, n. 3, p. 429-439, 2006. https://doi.org/10.1016/j.bios.2006.05.015

KAVETSKYY, T. et al. Dependence of operational parameters of laccase-based biosensors on structure of photo cross-linked polymers as holding matrixes. European Polymer Journal, v. 115, p. 391-398, 2019. https://doi.org/10.1016/j.eurpolymj.2019.03.056 
KOLOMYTSEVA, M. et al. Rapid identification of fungal laccases/oxidases with different $\mathrm{pH}-$ $\begin{array}{lllllll}\text { optimum. Process } & \text { Biochemistry, v. 62, p. 174-183, } 2017 .\end{array}$ https://doi.org/10.1016/j.procbio.2017.07.027

KOLOMYTSEVA, M. P. et al. Laccase isoform diversity in basidiomycete Lentinus strigosus 1566: Potential for phenylpropanoid polymerization. International Journal of $\begin{array}{llllll}\text { Biological Macromolecules, } & \text { v. 137, p. 1199-1210, } 2019 .\end{array}$ https://doi.org/10.1016/j.ijbiomac.2019.07.056

LOBSIGER, N. et al. YestroSens, a field-portable S. cerevisiae biosensor device for the detection of endocrine-disrupting chemicals: Reliability and stability. Biosensors and $\begin{array}{llllll}\text { Bioelectronics, } & \text { v. } 146, \quad \text { n. July, p. } & 111710,\end{array}$ https://doi.org/10.1016/j.bios.2019.111710

MACHADO, K. M. G.; MATHEUS, D. R. Biodegradation of Remazol brilliant blue R by ligninolytic enzymatic complex produced by Pleurotus ostreatus. Brazilian Journal of Microbiology, v. 37, n. 4, p. 468-473, 2006. https://doi.org/10.1590/S151783822006000400013

MISHRA, V. et al. Improvement of selective lignin degradation in fungal pretreatment of sweet sorghum bagasse using synergistic CuSO4-syringic acid supplements. Journal of $\begin{array}{llllll}\text { Environmental Management, } & \text { v. 193, p. 558-566, }\end{array}$ https://doi.org/10.1016/j.jenvman.2017.02.057

OOI, L. et al. Application of the cellular oxidation biosensor to Toxicity Identification Evaluations for high-throughput toxicity assessment of river water. Chemosphere, v. 247, p. 125933, 2020. https://doi.org/10.1016/j.chemosphere.2020.125933

RAMESH, A. V. et al. A Facile plant mediated synthesis of silver nanoparticles using an aqueous leaf extract of Ficus hispida Linn. f. for catalytic, antioxidant and antibacterial applications. South African Journal of Chemical Engineering, v. 26, n. November 2017, p. 25-34, 2018. https://doi.org/10.1016/j.sajce.2018.07.001

SANDEEP, S. et al. Detection of catechol using a biosensor based on biosynthesized silver nanoparticles and polyphenol oxidase enzymes. Portugaliae Electrochimica Acta, v. 37, n. 4, p. 257-270, 2019. http://dx.doi.org/10.4152/pea.201904257

SETHURAMAN, V.; MUTHURAJA, P.; MANISANKAR, P. Fabrication of an efficient polyaniline-polyphenol oxidase based biosensor for catechol. Analytical Methods, v. 5, n. 22, p. 6523-6530, 2013. https://doi.org/10.1039/C3AY41341A

SIMÓN-HERRERO, C. et al. Immobilized laccase on polyimide aerogels for removal of carbamazepine. Journal of Hazardous Materials, v. 376, p. 83-90, 2019. https://doi.org/10.1016/j.jhazmat.2019.05.032

SONG, Y. et al. Simultaneous electrochemical determination of catechol and hydroquinone in seawater using Co3O4/MWCNTs/GCE. Materials Chemistry and Physics, v. 234, n. May, p. 217-223, 2019. https://doi.org/10.1016/j.matchemphys.2019.05.071

VIDIGAL, S. M. et al. Yield performance of taro (Colocasia esculenta L.) cultivated with topdressing nitrogen rates at the Zona da Mata region of Minas Gerais. Revista Ceres, v. 63, n. 6, p. 887-892, 2016. http://dx.doi.org/10.1590/0034-737x201663060019

ZERAIK, A. E. et al. Desenvolvimento de um spot test para o monitoramento da atividade da peroxidase em um procedimento de purificação. Química Nova, v. 31, n. 4, p. 731-734, 2008. http://dx.doi.org/10.1590/S0100-40422008000400003 